
of Engineers ${ }_{\circledast}$

Engineer Research and Development Center

National Erosion Control Development and Demonstration Program

\title{
Lake Michigan Bluff Dewatering and Stabilization Study - Allegan County, Michigan
}

M. Eileen Glynn, Ronald B. Chase, Alan E. Kehew,

September 2012

James P. Selegean, Michael G. Ferrick,

and Clarissa M. Hansen

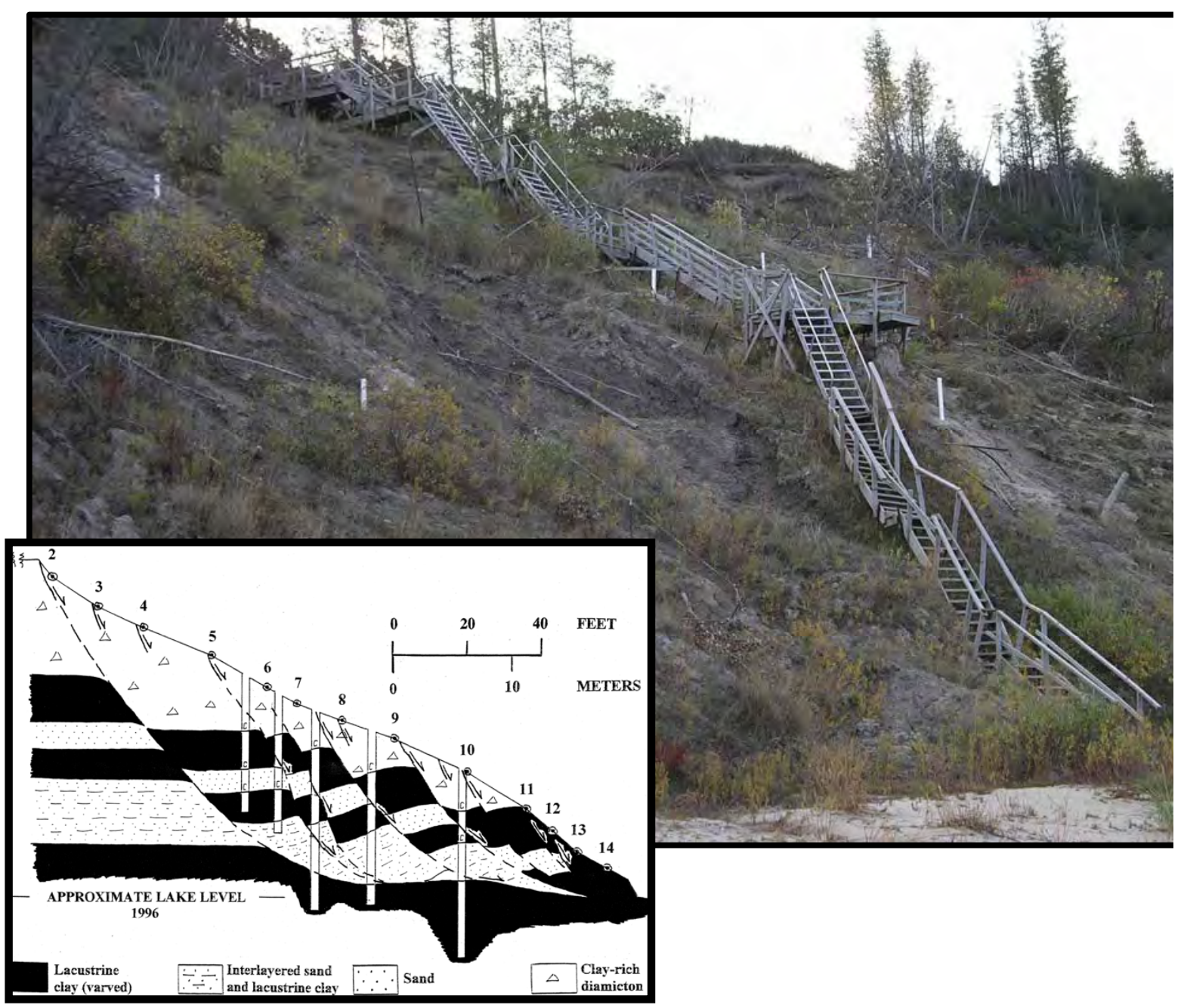




\section{Lake Michigan Bluff Dewatering and Stabilization Study - Allegan County, Michigan}

\section{Eileen Glynn}

Geotechnical and Structures Laboratory

U.S. Army Engineer Research and Development Center 3909 Halls Ferry Road

Vicksburg, MS 39180-6199

Ronald B. Chase and Alan E. Kehew

Department of Geosciences

Western Michigan University

Kalamazoo, MI 49008

James P. Selegean

U.S. Army Corps Engineers, Detroit District 477 Michigan Avenue

Detroit, MI 48226

Michael G. Ferrick (retired)

Cold Regions Research and Engineering Laboratory

U.S. Army Engineer Research and Development Center 72 Lyme Road

Hanover, NH 03755

Clarissa M. Hansen

Malcolm Pirnie, Inc.

406 Freedom Business Center

King of Prussia, PA 19406

Final report

Approved for public release; distribution is unlimited. 


\section{Abstract}

In the Great Lakes region, bluff recession is a major cause of residential, commercial, municipal, and federal property loss. The average rate of recession in Allegan County, Michigan, ranged from 1 to $2 \mathrm{ft}$ per year, from 1831 to 1958, or a total of 130 to $258 \mathrm{ft}$ over 127years (Powers 1958). From 1938 to 1996, a 0.1 to $1.7 \mathrm{ft}$ per year recession rate was measured, for a total land loss of 5 to $100 \mathrm{ft}$ over 58 years (Montgomery 1998). Reports show that recession rates are not uniform along the shoreline, nor are they similar during two different time periods at a given site (Chamberlin 1877; Powers 1958; Seibel 1972; Montgomery 1998; Chase et al. 2000). It is difficult to predict future rates of recession. Also, it is evident that recession has not slowed with the introduction of modern stabilization structures.

The purpose of this research is to investigate the natural factors that influence lake-bluff instability and to demonstrate an innovative approach (i.e., dewatering the bluff) for deterring or slowing the recession rate. Three geologically distinct sites along the Lake Michigan coast in Allegan County were chosen. In 2004, measurement instrumentation was installed at each of the sites. Part of each site was dewatered using submersible pumps or gravity drains, while another part of each site was not. A total of 76 in-place inclinometers (IPIs) and 28 vibrating wire piezometers (VWPs) among 26 monitoring wells, 45 dewatering wells, and two weather stations were installed.

The original work plan called for five seasonal cycles of dewatering tests. The sites were monitored from November 2004 to May 2007, and hourly data were collected. Data has not been analyzed in full due to a lack of funding since 2007. Therefore, no significant conclusions could be produced. At the time of this report, no conclusion can be made concerning the success of bluff dewatering as a mitigation strategy. Future reports are in the works.

DISCLAIMER: The contents of this report are not to be used for advertising, publication, or promotional purposes. Citation of trade names does not constitute an official endorsement or approval of the use of such commercial products. All product names and trademarks cited are the property of their respective owners. The findings of this report are not to be construed as an official Department of the Army position unless so designated by other authorized documents. 


\section{Contents}

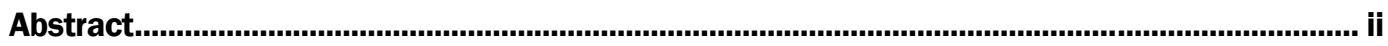

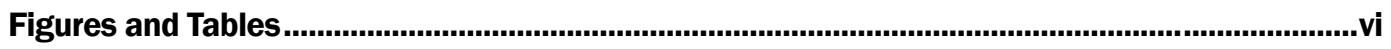

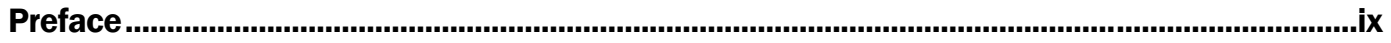

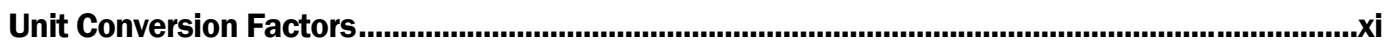

1 Introduction .................................................................................................................... 1

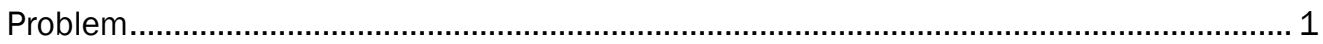

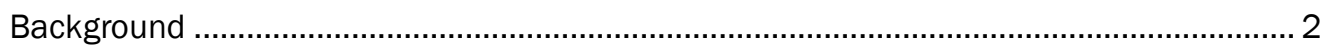

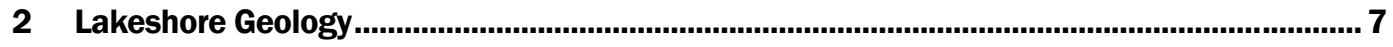

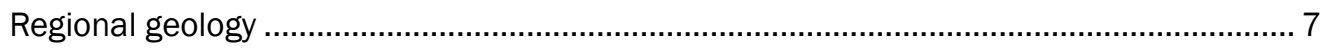

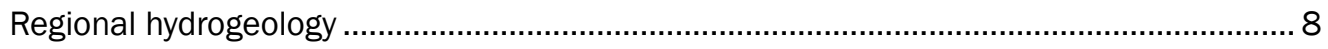

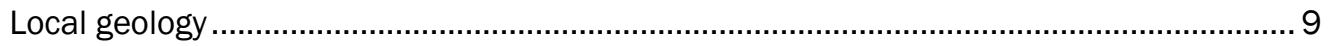

Site geology and hydrogeology (MPS, MPN, 116 th Avenue) ......................................... 11

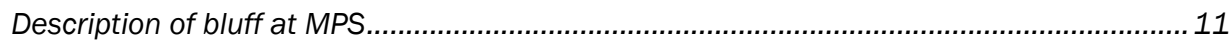

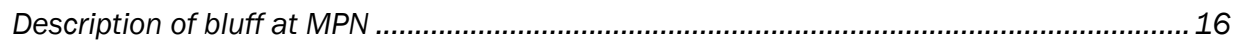

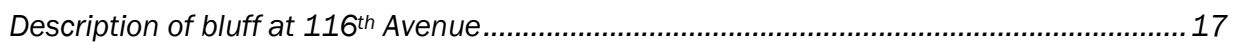

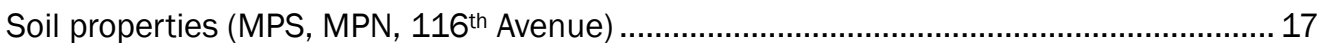

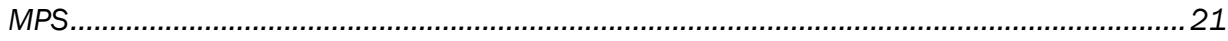

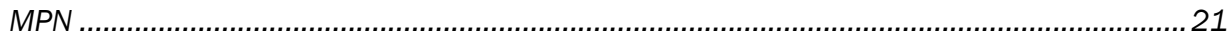

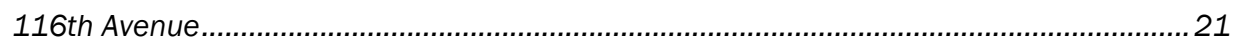

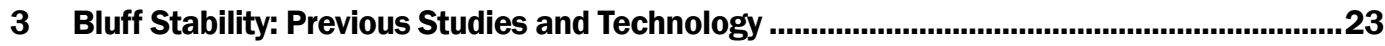

Field mapping: Lithology versus recession ....................................................................... 24

Monitoring slope movement: Pole-and-cable system........................................................ 24

Historic lake levels..................................................................................................... 28

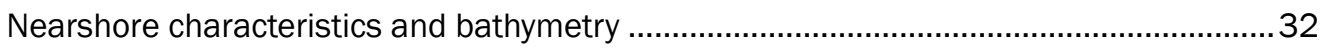

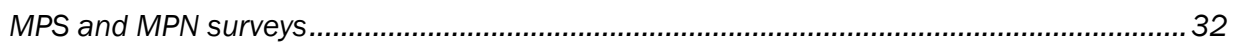

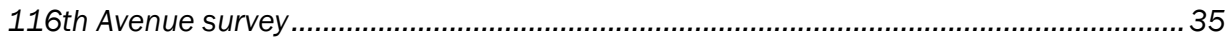

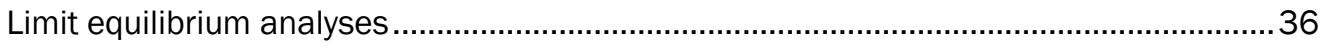

Correlation of pole translations to atmospheric conditions..........................................38

4 Conclusions: Previous Investigations ............................................................................41

5 Bluff Dewatering and Stabilization Demonstration ...............................................................43

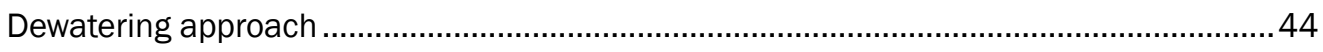

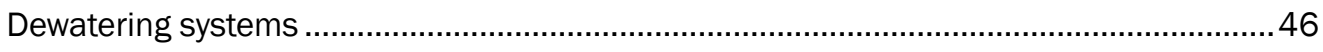

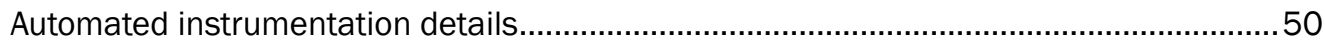

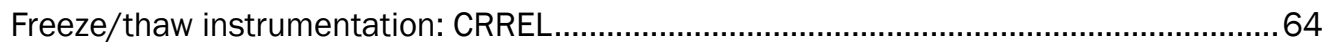

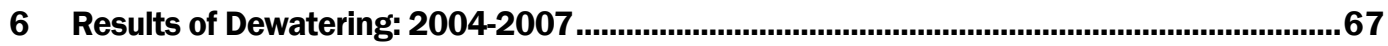




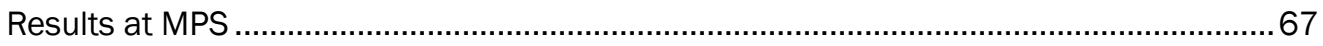

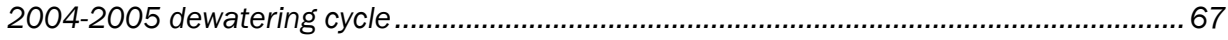

2004-2005 freeze/thaw analysis results........................................................................69

2005-2006 no-dewatering, 2006-2007 dewatering cycles .............................................. 72

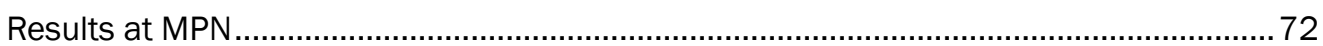

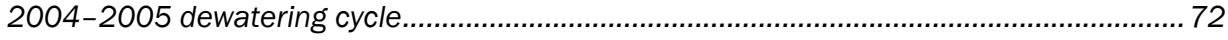

2005-2006 no-dewatering, 2006-2007 dewatering cycles .............................................73

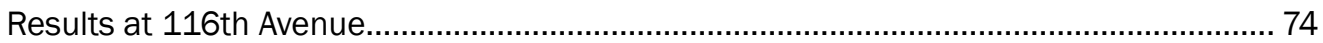

2004-2005 dewatering cycle....................................................................................... 74

2005-2006 no-dewatering, 2006-2007 dewatering cycles ................................................ 74

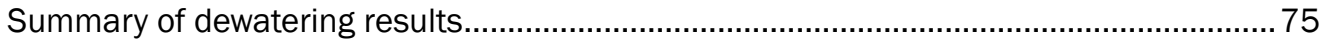

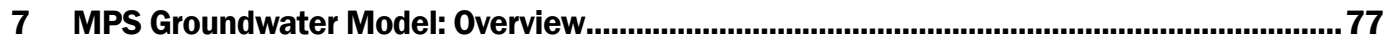

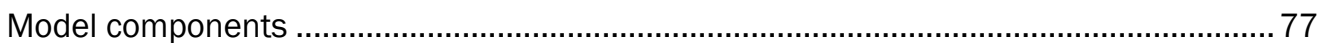

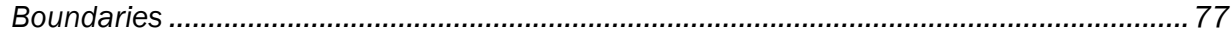

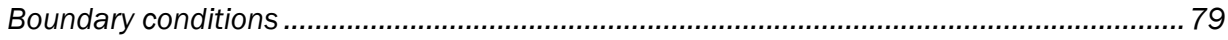

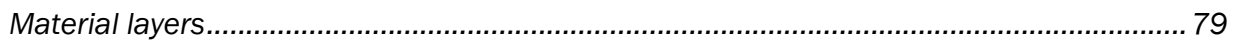

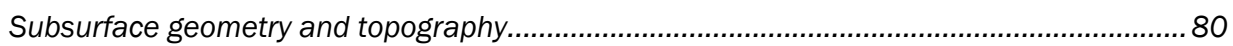

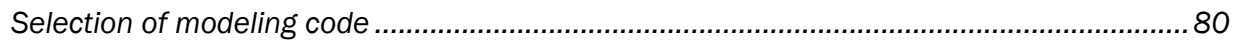

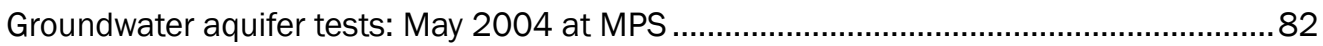

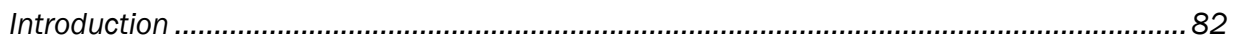

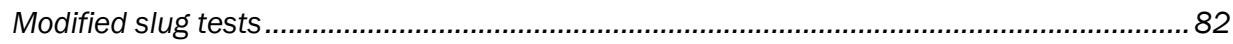

Individual pumping tests............................................................................................. 83

Collective pumping test ............................................................................................. 84

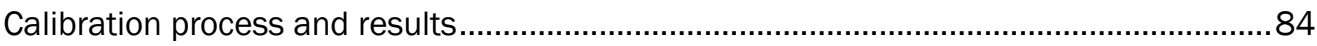

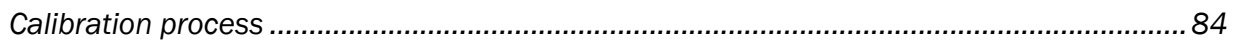

Calibration results (excerpt from Hansen et al. 2007) ………........................................ 85

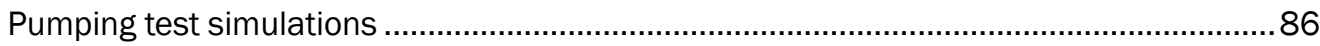

Long-term simulation: 100 days .............................................................................. 87

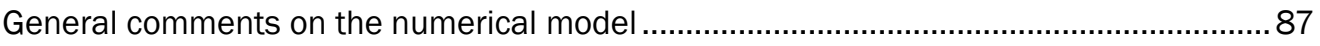

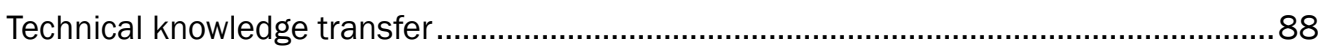

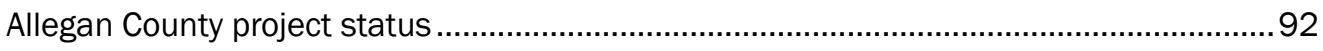

8 Current Conclusions for the Allegan Demonstration Project.........................................94

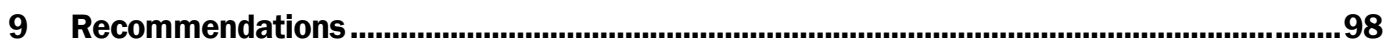

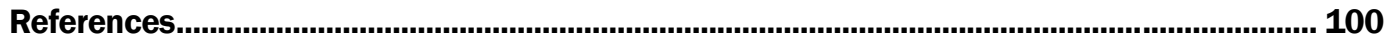

Appendix A: Detailed Geologic Logs for Rotosonic Drill Holes ALG-02-01 (MPS), ALG-

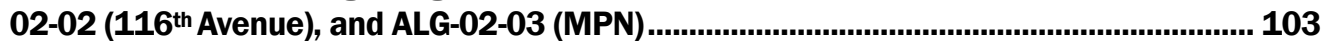

Appendix B: Summary of STS Laboratory Testing (2003) for Rotosonic Drill Holes and Vibrating Wire Piezometer Installation Details ..................................................................... 111

Appendix C: STS Laboratory Test Results (2005) - Samples from Instrumentation

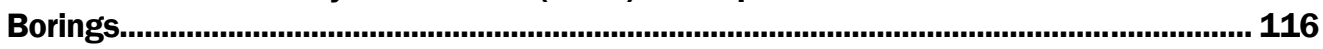

Appendix D: General Description of Aquifer Testing at MPS (May 2004)............................... 144 
Appendix E: Bibliography of Allegan County Bluff Stabilization Technology Transfer Documents.

Report Documentation Page 


\section{Figures and Tables}

\section{Figures}

Figure 1. Location of study area, Allegan County, Michigan. ............................................................ 3

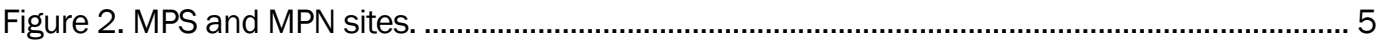

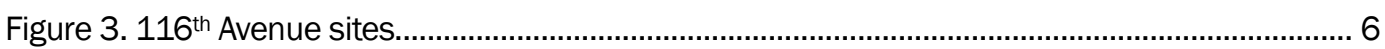

Figure 4. Regional stratigraphy. ............................................................................................. 7

Figure 5. Typical hydrogeology of the Great Lakes shoreline .......................................................... 8

Figure 6. Lake bluff morphology for Allegan County. .................................................................... 10

Figure 7. Six-mile profile showing detailed stratigraphy for the local area and between the

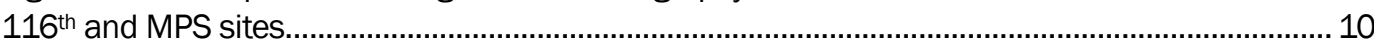

Figure 8. Geologic logs of rotosonic borings, from left, ALG-01 (MPS), ALG-02 (116th), and ALG-03 (MPN). Installed vibrating wire piezometers in each boring, 2004................................... 12

Figure 9. Model cross section, top, (by Ronald B. Chase) showing groundwater seeps and interpreted failure slip surfaces, with respect to bluff stratigraphy, bluff height, and above average 1997 lake level (Chase 2003, personal communication); bottom photo, MPS bluff in winter 2002.

Figure 10. MPS site plan view showing locations of survey lines, monitoring instruments, and wells.

Figure 11. Cross section, top, for MPN to show height of bluff (by Ronald B. Chase); bottom photo, bluff at MPN in 2002.

Figure 12. MPN site plan view showing locations of survey lines, instruments, and well locations. Perrenial Seeps (PS) locations identified.

Figure 13. Cross section, top, of 116th showing height of bluff above 2003 average lake level at 176 m (577 ft) (by Ronald B. Chase); bottom photo, site visit in December 2002.

Figure 14. Plan view of $116^{\text {th }}$ site showing contour map with instrument and well locations............... 19

Figure 15. Piezometric readings. ................................................................................................ 20

Figure 16. Recession rate versus bluff lithology ………............................................................... 25

Figure 17. Example of pole-cable survey system. Poles should be anchored in clay layers............... 25

Figure 18. Last pole, left, of the calibrated pole-cable system and concrete anchor, and, right, calibrated cable system shortly after installation at $116^{\text {th }}$ Avenue...

Figure 19. (a) Original position of poles at MPS (after Chase et al. 2001b) and

(b) displacement of poles five years later. Cross-section b interpreted by Ronald B. Chase, using the Balanced Cross Section Method................................................................................. 27

Figure 20. Description of the Balanced Cross Section Method........................................................2.

Figure 21. Cross sections developed from drilling and split spoon sampling for the installation of pumps and monitoring equipment in late 2003.

Figure 22. Part A, lake levels in meters, from 1996 through 2000. Great Lakes water levels for Lake Michigan/Huron graphed by month. NOTICE: All data contained herein are preliminary in nature and therefore subject to change.

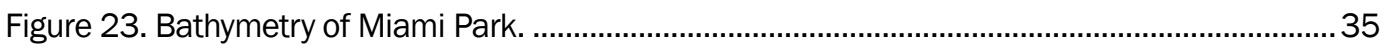

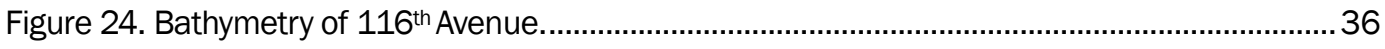


Figure 25. Graphic result of limit equilibrium analysis of Slip Surface 1 in Figure 26. Results of computer simulations (Spencer Method). Space between red dots width of slices. Force vectors at the base of each slice. Total stress = green, effective stress = red, and pore pressure $=$ blue.

Figure 26. Displacement of Survey Poles 1 through 11 on Survey Line 2 at MPS versus time (1996-2002).

Figure 27. Plot showing annual trends in wave events, monthly precipitation, ambient air temperature, and water table depths below the bluff top and their correlations to slope movement at MPS and $116^{\text {th }}$ Avenue. Only those storm events with wave heights sufficient to reach the base of the bluff are plotted.

Figure 28. Field well installation diagram.

Figure 29. Data-control shed, clockwise from top left, atop each bluff site; pump and instrument control boxes and DAUs inside shed; and construction of shed foundation showing buried conduits for instrumentation wiring.

Figure 30. Stratigraphic contacts and slumping, from top, inferred-constructed in June 2003 using the Balanced Cross Section Method (after Chase et al. 2007a) and standpipe boring geology; modification of top cross section (by Ronald B. Chase) after drilling four instrumentation borings; and MPS wells and inclinometers, installed.

Figure 31. MPN, Line 2, top, and Line 3, bottom, cross sections, modified after drilling instrument and well borings. Note the large percentage of sand in the sections (cross sections interpreted by Ronald B. Chase). Error on bottom figure: Line 3, not 5 ...

Figure 32. 116th Avenue cross sections for Survey Lines 2 and 3. Sections modified after drilling borings for instrumentation and wells.

Figure 33. MPS and $116^{\text {th }}$ Avenue initial sections.

Figure 34. Green drilling platform and red drill at MPS suspended by $100-\mathrm{ft}$ crane. Stairs have been rebuilt three times by property owners because of slope failures. 55

Figure 35. Piezometer schematic, downhole electronic pressure transducer with thermistor..

Figure 36. Schematic of downhole inclinometer, instrument for measuring deflection of borehole.

Figure 37. Solar-powered complete weather station at MPS. Identical system at 116th Avenue. Installed by WMU, STS, and USACE, Detroit District. 57

Figure 38. Soil moisture probes, soil resistivity probes, and thermistor strings installed in vertical borings, next to orange stakes. Web camera, data logger, and solar panel were installed as a cluster, foreground...

Figure 39. The pole ( 4 and 8 , in dewatered section of MPS) and cable (Line 2 ) data, plus all temporal relations regarding groundwater, climate, precipitation, and wave action, compiled through September 2006 at MPS. Dewatering cycles November 2004-May 2005, and November 2006-May 2007, show marked decrease in pole movement.

Figure 40. CRREL air temperature data, MPS, May 2004 to June 2005, recorded by data logger. This plot compares well to air temperature plotted by weather station at MPS. Data gap in June and July 2004 was because of an equipment setup error.

Figure 41. Soil temperature from thermistor strings, January to June 2005 , for the dewatered and control sites at MPS

Figure 42. Soil moisture results from January to June 2004, top two plots; 2005, bottom two plots. Note high variation in shallow depths at remediated site during dewatering. 71

Figure 43. Illustration of numerical model's boundary conditions. 
Figure 44. Extraction well locations. Red wells indicate productive pumping wells in May 2004. Black wells were dry in May 2004

Figure 45. TIN describing the ground surface.

Figure 46. Figure showing borehole location and corresponding stratigraphic information applied to the groundwater model.

Figure 47. Finished computational mesh with material types assigned.

Figure 48. Typical cross section of finished computational mesh. The mesh has 124,786

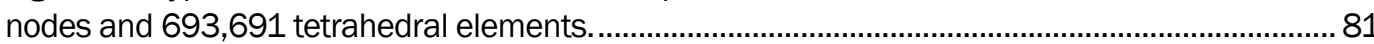

Figure 49. Piezometers and wells on bluff face combine the two figures above. 84

Figure 50. Model correctly locates flow from the bluff face above low permeable layers that contact higher permeable layers (sand).

Figure 51. Mosel Bluff, clockwise from top, Lake Shore Road, Sheboygan County Wisconsin; directional drill rig atop Mosel Bluff and landside of Lake Shore Road; and as-built, plan view: nine directionally drilled drains from landside of Lake Shore Road to bluff toe.

Figure 52. Slope, clockwise from top left, after cut and fill of the surface material; installation of gravity drains and toe revetment; and view of drain outlet at the revetment just after construction.

Figure 53. View after construction of gravity drained Mosel Bluff, Sheboygan County, Wisconsin. Note heavily constructed revetment at toe to prevent foreshore erosion.

\section{Tables}

Table 1. Summary of instruments installed at MPS, MPN, and 116 th Avenue ..................................58

Table 2. Inclinometers and wells Installed at MPS, MPN, and $116^{\text {th }}$ Avenue................................59

Table 3. Inclinometer details for MPS, MPN, and 116 th Avenue.....................................................62

Table 4. Piezometer details for MPS, MPN, and $116^{\text {th }}$ Avenue........................................................ 64

Table 5. Final material layers thicknesses and boundary conditions. ............................................. 79

Table 6. Details of modified slug tests conducted in standpipes................................................... 83

Table 7. Individual field-test, flow-rate values for productive extraction wells. .................................. 83

Table 8. Final calibrated parameter values for the model............................................................... 85

Table 9. Comparison of field measured extraction rates during the 2-hr test and the values used in the model during the 100-day run. 


\section{Preface}

Dr. Ronald B. Chase, Department of Geosciences, Western Michigan University (WMU), was Principal Investigator. Design and conduct were performed by Chase, in coordination with the U.S. Army Engineer Research and Development Center's (ERDC) Geotechnical and Structures Laboratory (GSL) and Coastal and Hydraulics Laboratory (CHL). The Great Lakes Hydraulics and Hydrology Office of the U.S. Army Corps of Engineers (USACE), Detroit District, along with the WMU Department of Geosciences, oversaw construction and provided technical guidance.

Dr. Alan E. Kehew, WMU, was co-advisor for the project. Former WMU graduate students William Montgomery, Rennie Kaunda, Mark Worrall, Gregory Young, William Bush, and Amanda Brotz contributed with data analysis, soil strength testing, and digital modeling of slope failures. WMU in-kind funding included personnel release time, equipment transfers, facility use, site maintenance, and administrative duties.

Dr. J ames P. Selegean was Project Manager at the Detroit District. The drilling technology associated with project construction was designed by Ronald L. Erickson, formerly of the Detroit District. Drilling contractor was Charles Leucht of STS, Ltd., Chicago. Instrumentation installation was directed by Matthew D. Emrick of STS, Associates. Field assistance was provided by Kaunda and Brotz. Selegean facilitated and oversaw design and construction of the project and directed the bathymetry surveys.

The Principal Investigator at ERDC for this project was M. Eileen Glynn, Geotechnical Engineering and Geosciences Branch (GEGB), Geosciences and Structures Division (GSD), GSL. At the time of her research, Dr. J ack E. Davis was Technical Director and William R. Curtis was Associate Technical Director of the Flood and Coastal Storm Damage Reduction Research and Development Program (FCSDR) at CHL, and Drs. J oseph Koester and Monte Pearson, who provided general supervision, were with the GEGB. Dr. Robert L. Hall was Chief of the GSD; Dr. William P. Grogan was Deputy Director of the GSL; and Dr. David W. Pittman was Director.

At the time of publication, Curtis was Technical Director of FCSDR. Dr. Richard Olsen was Chief, GEGB, and Bartley P. Durst was Chief, GSD. 
Grogan was Acting Director, GSL, and Henry S. McDevitt was Acting Deputy Director. COL Kevin J. Wilson was Commander and Executive Director of ERDC, and Dr. J effery P. Holland was Director.

Funding was provided by the National Shoreline Erosion Control Development and Demonstration Program, FCSDR at ERDC, the Regional Sediment Management (RSM) research under the System-Wide Water Resources Program at ERDC, and in-kind monies and activities of WMU. The National Shoreline Erosion Control Development and Demonstration Program was authorized by the Water Resources and Development Act of 1996 (Public Law 104-303, 110 Statute 3658), dated 12 October 1996. The FCSDR and RSM programs are supported by Headquarters, U.S. Army Corps of Engineers (HQUSACE), Washington, D.C.

The RSM research funded the installation of specialized freeze/ thaw instrumentation and Web cameras, in addition to the work of Principal Investigators Michael G. Ferrick and Christopher R. Williams of ERDC's Cold Regions Research and Engineering Laboratory (CRREL).

The report was written by Glynn, Chase, Kehew, Ferrick, Selegean, and Clarissa M. Hansen of Malcolm Pirnie, Inc., formerly of CHL. 


\section{Unit Conversion Factors}

\begin{tabular}{|l|c|l|}
\hline Multiply & By & To Obtain \\
\hline feet & 0.3048 & meters \\
\hline gallons (U.S. liquid) & $3.785412 \mathrm{E}-03$ & cubic meters \\
\hline inches & 0.0254 & meters \\
\hline miles (U.S. statute) & $1,609.347$ & meters \\
\hline
\end{tabular}




\section{Introduction}

\section{Problem}

Bluff recession along the shores of the Great Lakes creates significant property damage and land loss annually. In the Great Lakes region, high lake levels and wave action are the major causes of shore and toe erosion and, therefore, bluff recession (Davis et al. 1975; Davis 1976; Kamphuis 1987). Hence, engineering solutions for coastal bluff erosion have focused on traditional slope stability analyses and reinforcement of the bluff toe. This long-held belief that toe erosion is the cause of recession has guided the engineering solutions, even though researchers have discovered that bluff recession is caused by the interaction of several key parameters (Edil and Vallejo 1980; Sterrett and Edil 1982; Buckler and Winters 1983;

Montgomery 1998; Chase et al. 1999a, 1999b). Consequently, the constructions of concrete seawalls, steel sheet-pile bulkheads, stone revetments, etc., are the common methods used today for combating bluff recession in the region. Unfortunately, these structures are unable to withstand the forces acting on them. They gradually are displaced or destroyed by freeze/ thaw action, catastrophic failure of the bluff above, intense storm waves, or they are covered up by beach or slumping bluff materials. These engineered structures are expensive to build, not aesthetically pleasing, might interrupt access to the beach, can disrupt littoral transport, and normally are short lived.

This research has documented numerous bluff failures during the past 10 years (1996 to 2006) within the study area, and none support any evidence of being caused by toe erosion. Lake levels have been low since 2001 and few storm waves have reached the bluff, yet slumping and recession of the bluffs continue. Clearly, other factors besides wave action erosion are influencing bluff recession.

Common techniques to retard bluff recession have been largely unsuccessful because they address one factor, wave action, while multiple factors influence stability. The major factors that influence coastal stabilization along the Great Lakes can be grouped into three categories: variation in bluff lithology, bluff/ groundwater interaction (including effects of groundwater freeze and thaw), and downcutting of the backshore by wave power. Dewatering of shore bluffs is a technique that addresses two of the 
three categories: bluff lithology and groundwater interaction. If dewatering is used alone or in combination with methods that retard downcutting, bluff recession rates should be decreased significantly.

This report describes a demonstration project in which bluff dewatering is used as an alternative to conventional coastal stabilization methods. Three stratigraphically different bluffs have been dewatered with active and passive methods and are compared to control sites in adjacent areas. This research focuses on bluff stabilization and failure mechanisms with respect to bluff lithology and hydrogeology.

\section{Background}

Erosion problems along the Lake Michigan shore of Wisconsin and Michigan were first recognized in the 1800s, were researched throughout the 1900s, and continue to be an important topic today (Buckler and Winters 1983). Many researchers have contradictory conclusions about the causes and the rates of bluff recession around Lake Michigan. However, when mitigation strategies are chosen, much of the blame has been placed on high lake levels and subsequent erosion of the foreshore and bluff toe.

Comparison of erosion rates recorded in the many studies is difficult to impossible because of inconsistencies in the data collection methods. Sometimes, no indication is given as to the time span that the data represent or the method of collection, field, map, or aerial photographic measurement (Buckler 1987). However, the historical reports show that recession rates are not uniform along the shoreline, nor are they necessarily similar during two different time periods at a given site (Chamberlin 1877; Powers 1958; Seibel 1972). Therefore, with the current knowledge, it is difficult to predict future rates of recession in any particular location.

However, studies of the west shore of Lake Michigan and elsewhere suggest that variations in slope inclination, vegetation, stratigraphy, position of groundwater table, frost action, seepage effects, sheet wash, weathering, and other factors will influence slope stability (Buckler and Winters 1983; Edil and Vallejo 1980). These studies did not include much interpretation or data on these other factors that influence stability. Recent studies of the southeastern shoreline (Montgomery 1998; Chase 1990) have described by comprehensive analysis the complex interplay of many of these factors. 
Ronald B. Chase, Western Michigan University (WMU), has studied bluff geology and associated features along the Allegan County shoreline since the late 1980s (Figure 1). Most recently (1996 to 2001), he has documented with others slope displacement data with respect to bluff lithology, atmospheric temperature, precipitation, groundwater levels, periodic freezing of bluff surfaces, and wave activity (Chase et al. 2001a, 2001b). Slope stability analyses of the Allegan County bluffs using limit equilibrium models indicated groundwater effects as central to slope stability during the study period. Therefore, dewatering these slopes seemed an obvious solution for stabilization, but one that was untested along Lake Michigan.

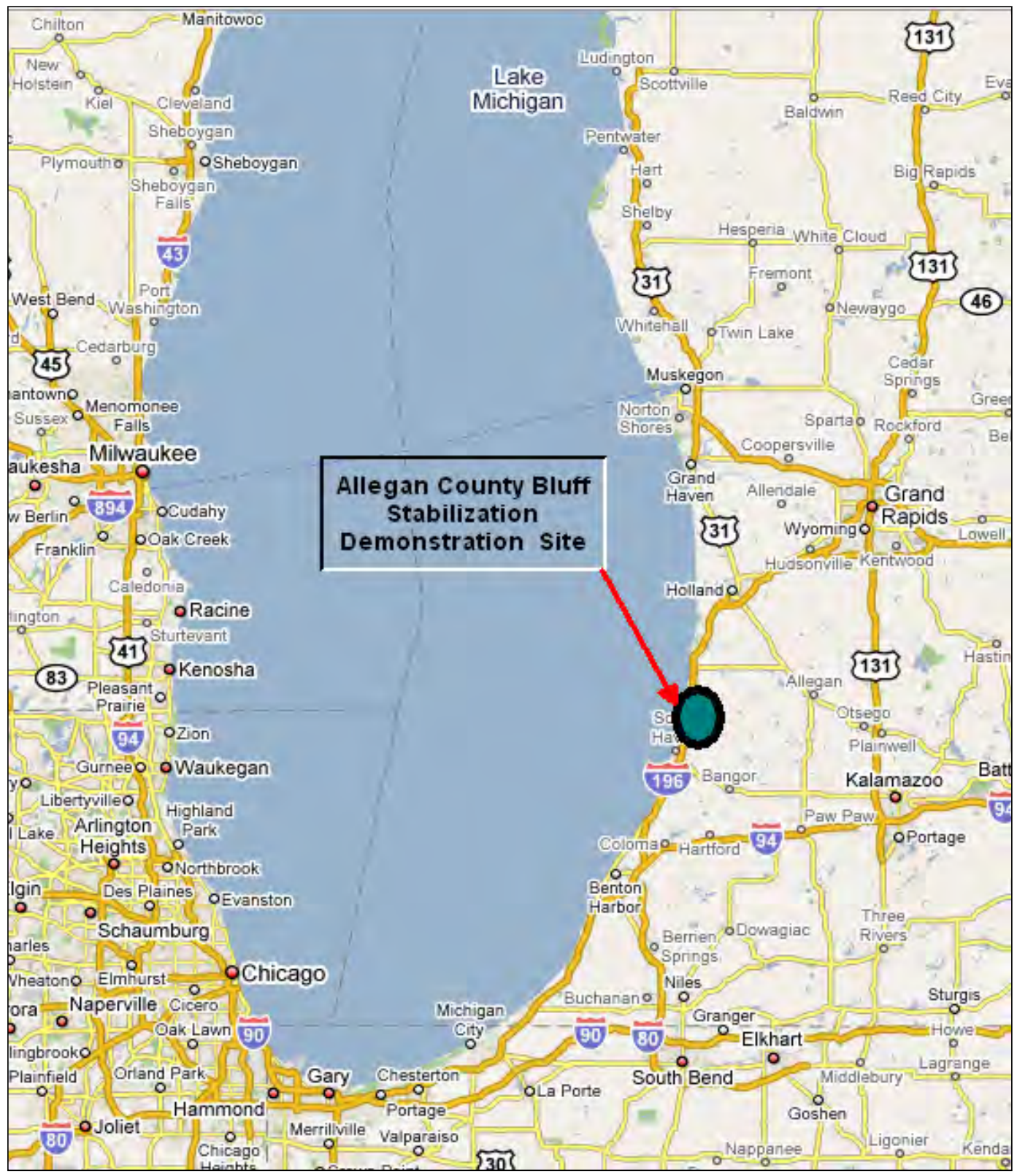

Figure 1. Location of study area, Allegan County, Michigan. 
Because of the high quality and quantity of geologic/ erosion data collected from the Allegan County bluffs, it was selected as a prime demonstration area for the National Erosion Control and Development and Demonstration Program, authorized by the U.S. Congress within Section 227 of the 1996 Water Resources and Development Act (WRDA). The basic goals are to assess and advance beach erosion control, develop and demonstrate innovative methods of erosion control, and to communicate the findings to public, state, and local coastal managers.

Three stratigraphically diverse project areas within Allegan County were selected for the dewatering study: Miami Park South (MPS), Miami Park North (MPN) (both in Figure 2), and 116th Avenue (116th) (Figure 3). These sites are roughly 500 to $1,000 \mathrm{ft}$ in length and occur along the southeastern coast of Lake Michigan, within 9 miles of South Haven, Michigan.

The objective of the Allegan County demonstration project is to evaluate the effectiveness of dewatering strategies, active and passive, on slope stabilization at these three sites. The project (funded by the National Erosion Control and Development and Demonstration Program, Regional Sediment Management Research Program and WMU) is a coordinated effort of the U.S. Army Engineer Research and Development Center (ERDC), WMU, and the U.S. Army Corps of Engineers (USACE) Detroit District. 

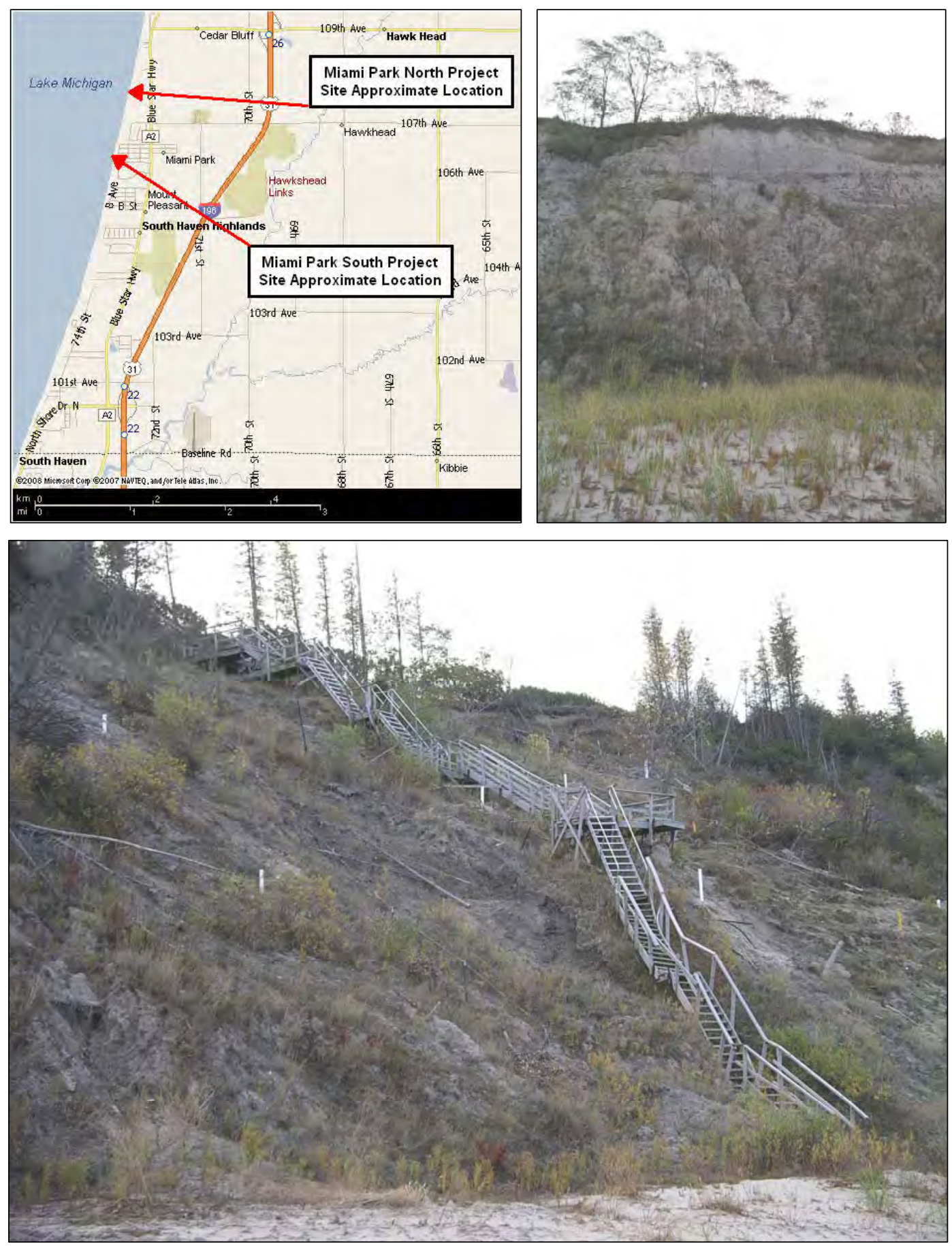

Figure 2. MPS and MPN sites (top right photo, bluff at MPN; bottom photo, bluff stairs at MPS). 

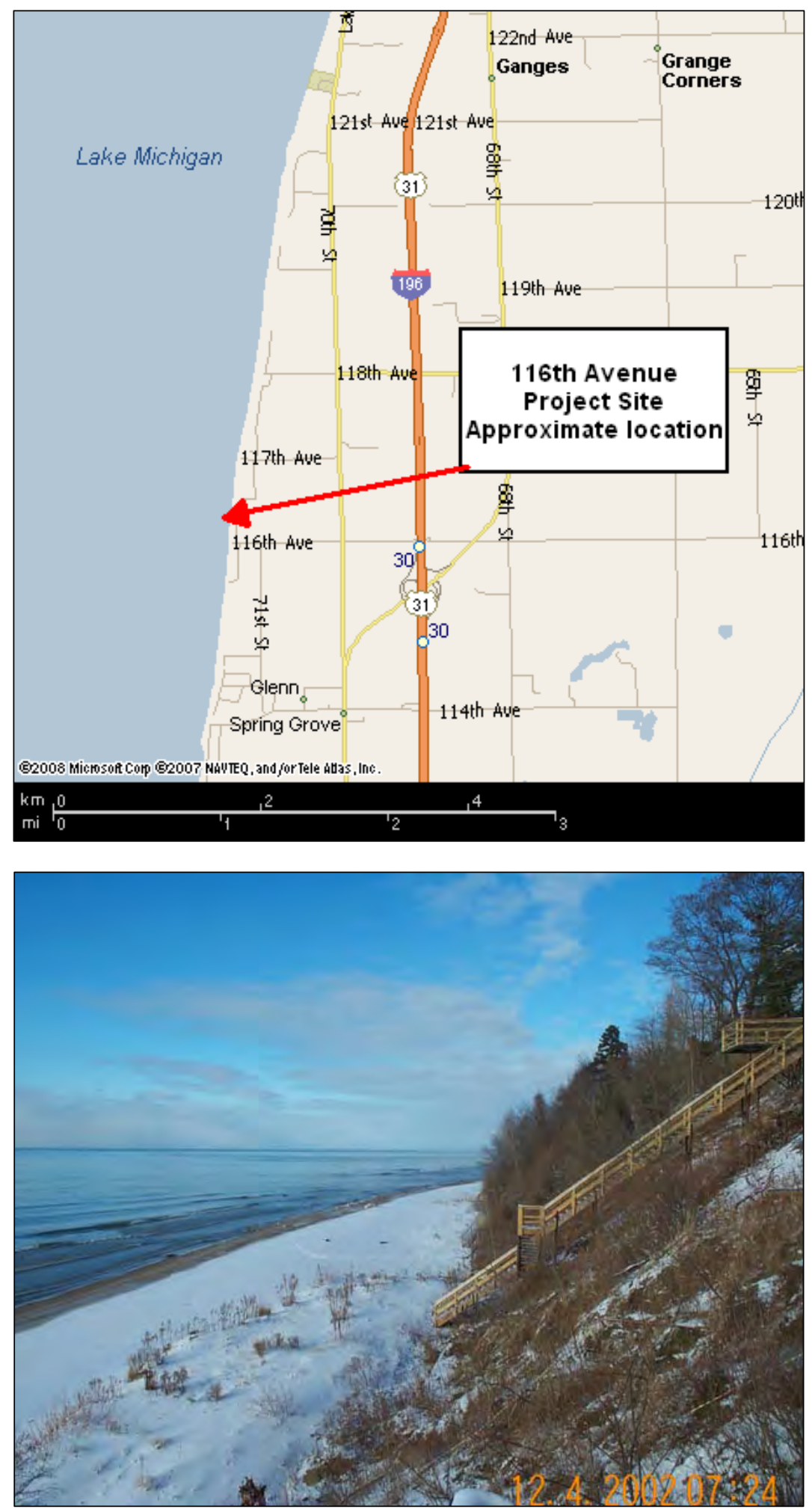

Figure 3. $116^{\text {th }}$ Avenue site. 


\section{Lakeshore Geology}

\section{Regional geology}

Geologically, the southeastern shore of Lake Michigan is classified as part of the Lake Border Morainic System (Farrand and Bell 1982). Lake Michigan bluffs cut the moraine in the region. Three Lake Michigan lobe till sheets are exposed along the shoreline. A stratigraphic column developed by Monaghan et al. (1986) describes regional units (Figure 4).

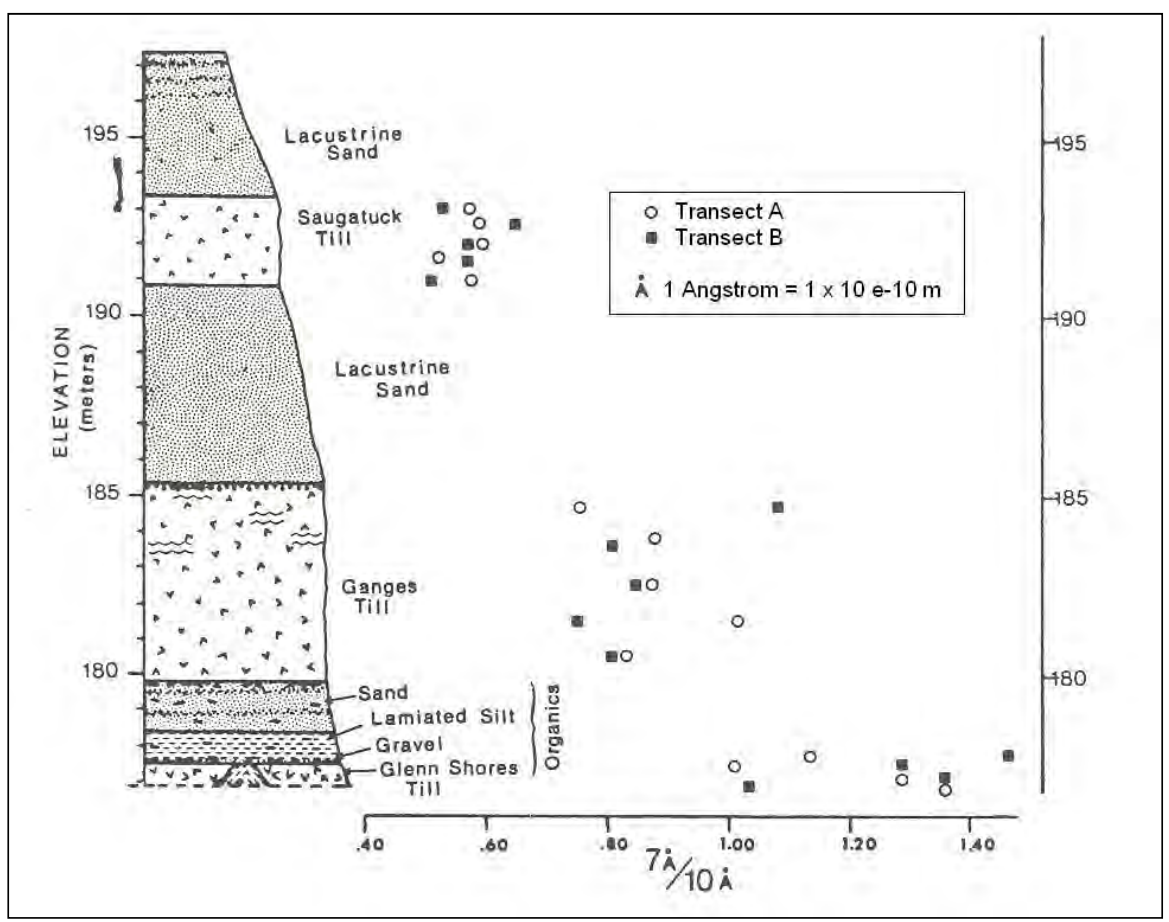

Figure 4. Regional stratigraphy (after Monaghan et al. 1986).

Thicknesses of these units vary greatly from one location to another; however, Farrand and Bell (1982) provide a good description of unit contacts. The Glenn Shores Till, the lowest of the three, is overlaid by stratified silt, sand, and gravel. The Ganges Till, middle, and Saugatuck Till, uppermost, are overlaid by lacustrine sediments (Figure 4). The Ganges Till is overlaid by a lacustrine sand deposit, and the contact between the two is sharp. Above the lacustrine sand lies the Saugatuck Till. The contact between Saugatuck Till and the underlying sand is also sharp (Monaghan et al. 1986). The Saugatuck Till is overlaid by lacustrine sand Lake Chicago sediments, and the contact is more gradational. 
The three tills have been characterized by Monaghan et al. (1986) using grain-size analysis and X-ray diffraction of their clay-size fractions. Results of the grain-size analyses were similar and, therefore, do not provide a useful means of till identification. The results of the clay-mineral analyses show that a significant stepwise increase in the 10 angstroms $(\AA)$ clay relative to $7 \AA$ clay occurs from the lowermost till unit to the uppermost till (Figure 4). Glenn Shores Till has a mean $7 \AA / 10 \AA$ ratio of 01.22 , that for Ganges Till is 0.85 , and that for Saugatuck till is 0.58. The three till units are most likely to represent till facies of different ice advances (Monaghan et al. 1986).

\section{Regional hydrogeology}

General hydrologic characteristics of bluffs adjacent to large water bodies are shown in Figure 5 (Keillor 2002). Groundwater infiltrates into the soils from surface water sources and off-site groundwater sources and moves to the slope face where water exits as a seep or spring. All coastal properties have groundwater flow beneath them; the ground adjacent to and lower than the lake surface elevation generally will be saturated (Keillor 2002). The surface of this saturated zone is the regional water table, which is at lake level at the bluff face and gently rises inland.

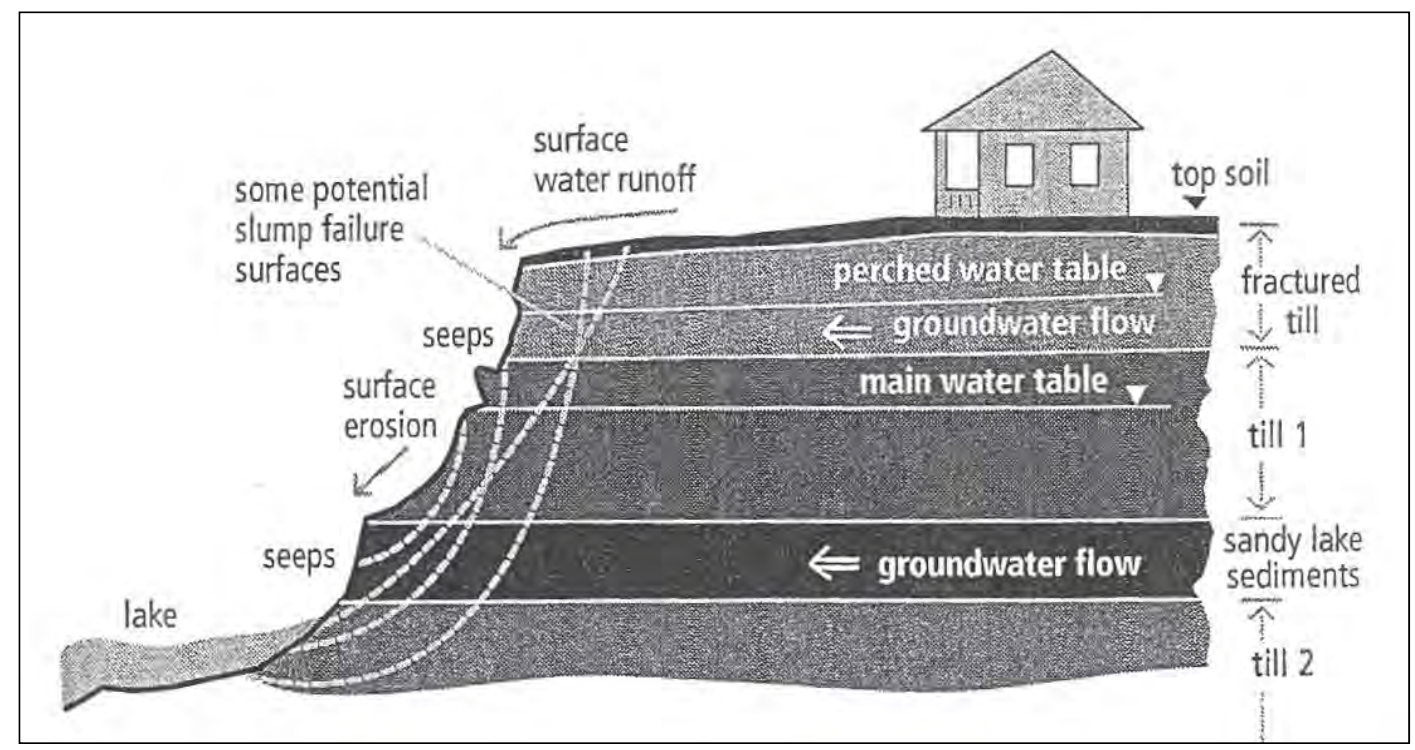

Figure 5. Typical hydrogeology of the Great Lakes shoreline (after Keillor 2002).

Bluffs that contain alternating layers of high (sand) and low (silt and clay) permeabilities typically contain perched water tables, that is, water above the main water table or saturated zone. A perched water table forms 
because clay layers beneath sand layers retard the downward movement of infiltrating water; thus the water will move horizontally within the sand layers and exit at the bluff face. Bluffs with perched water tables are the most susceptible to slope instability during periods of slow, prolonged precipitation, snowmelt, and freezing temperatures (Keillor 2002).

Slow and prolonged precipitation, or snowmelt, can cause a perched water table to rise, which adds weight to the soil mass and decreases cohesion and normal stress between soil particles. If the sand layer cannot drain water freely (i.e., it contains significant fine-grained particles or the bluff face is frozen) then instability is likely with a rise in its phreatic surface. Regardless of fine content within the sands, during cold periods freezing of the ground surface blocks the normal seepage exits and causes a significant buildup of water storage and pore pressure. Thus, slope movements and failures tend to initiate during cold periods, accelerating during spring thaw and decreasing during the summer months (Chase and Kehew 2000; Keillor 2002).

\section{Local geology}

The shoreline in the study areas, between the cities of South Haven and Saugatuck (approximately 20 miles) within Allegan County, is representative of the local bluff geology. The area has been studied in detail by Chase (1990), Chase et al. (2001), Montgomery (1998), and Monaghan et al. (1986) among others. All three tills (Ganges, Saugatuck, and Glenn Shores) are exposed just west of the town of Glenn; however, the lower till (Glenn Shores) dips below lake level and is exposed only approximately $50 \mathrm{ft}$ north and south of the section described by Monaghan et al. (1986) (Figure 4).

Typical beach morphology for this area is shown in Figure 6. Bluffs typically rise from a nominal 40 to $110 \mathrm{ft}$ above lake level. A bluff is defined as a lakeward facing steep slope composed of unconsolidated material landward of the shoreline. Recession is the landward movement of the face and the crest of the bluff resulting from erosion (Buckler and Winters 1983).

Chase (1990) describes the Ganges Till as continuous for the length of the area but extremely variable in thickness. The lacustrine sand above the Ganges Till also is extremely variable in thickness and may be a thin gravel lens, or up to $44 \mathrm{ft}$ of graded sand beds, planar and trough cross-beds, thin clay lenses and gravel layers. The Saugatuck Till is a discontinuous, locally massive silty-clay till and locally interlayered till and sand. The upper sand of the Lake Chicago sediments is constant in thickness, but locally absent in the study area (Chase 1990). 


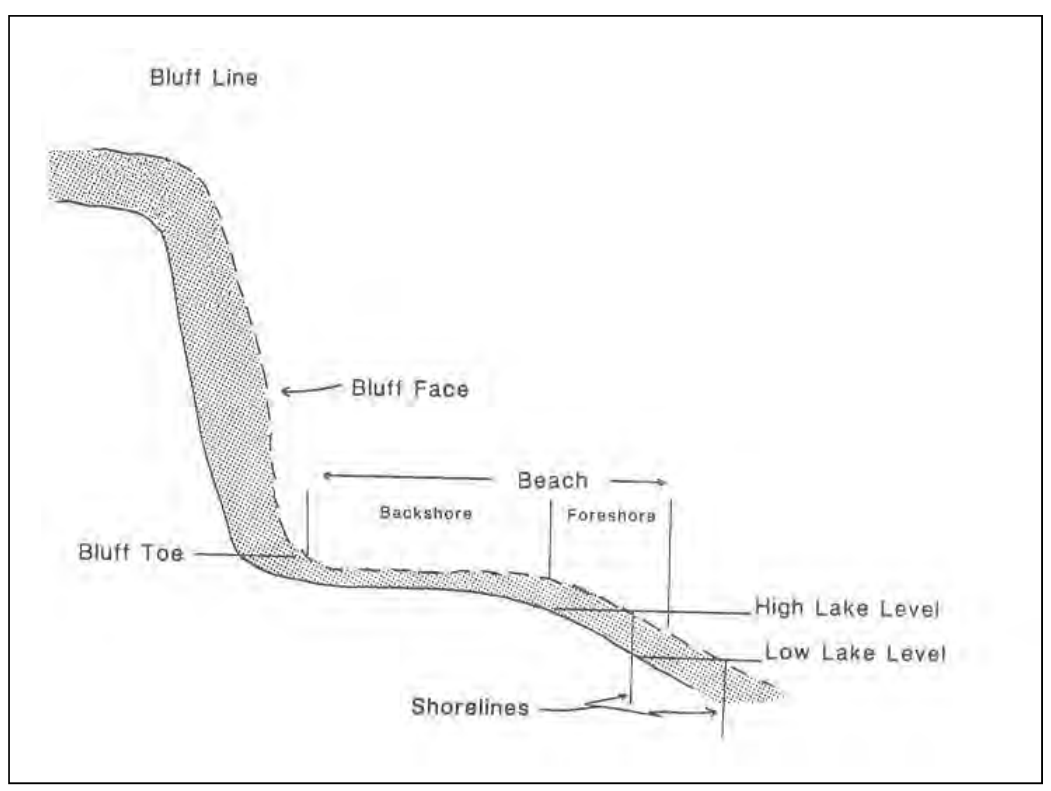

Figure 6. Lake bluff morphology for Allegan County (after Raphael et al. 1988).

Deposits in these bluffs include fine to medium-grained, buff-coloned, laminated to cross-bedded sand interbedded with reddish brown, often laminated clay; and reddish-brown to gray to blue-gray diamicton (till) containing clasts ranging in size from clay to boulders. Environments of deposition for the sand are interpreted as lacustrine to fluvial-deltaic, while the very fine-grained clay is lacustrine (Montgomery 1998). The tills occur as layers varying in thickness from fewer than $3 \mathrm{ft}$ to more than $20 \mathrm{ft}$. The stratigraphy varies greatly horizontally and is difficult to laterally correlate sequences. Figure 7 (Chase 1990) shows this variation in the deposits along a 6-mile profile between the 116th and MPS sites.

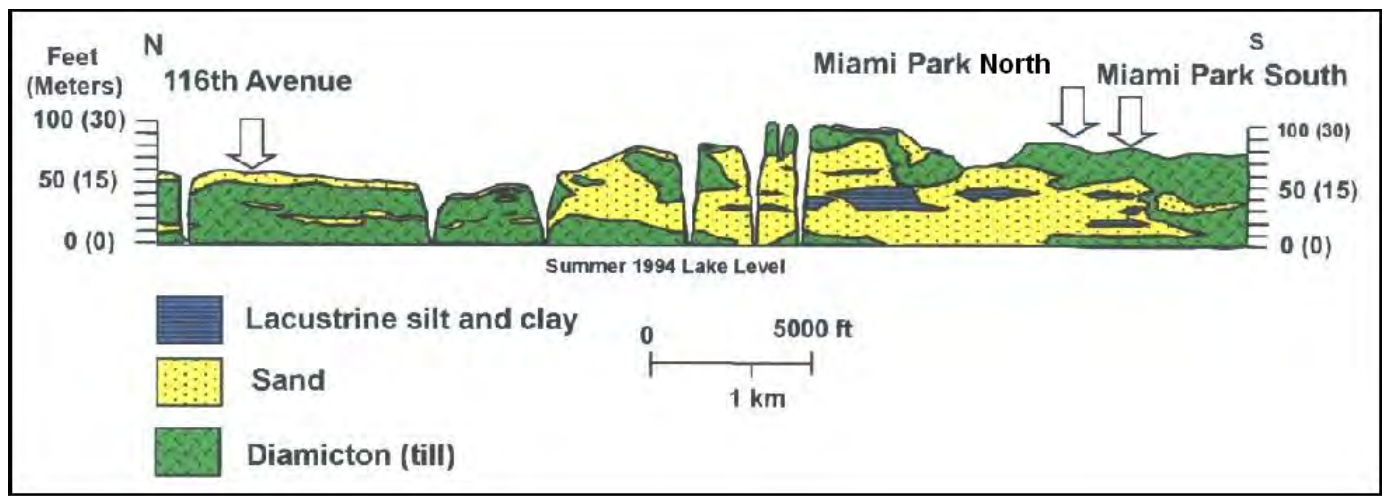

Figure 7. Six-mile profile showing detailed stratigraphy for the local area and between the $116^{\text {th }}$ and MPS sites (after Chase et al. 2007b). 


\section{Site geology and hydrogeology (MPS, MPN, 116 th Avenue)}

Each site contains layers of sand, till, silt, silty clay, and some gravel. Each site has a few feet of post-glacial sand on the bluff tops, but the stratigraphies (layering of materials) differ from there to the beach. In general, they can be summarized into three basic material types: mixed sand/ clay (MPS), dominantly sand (MPN), or dominantly clay (116 th Avenue) (Montgomery 1998). However, in detail, their stratigraphic differences are in the types, proportions, and positions of the clay layers, as shown in the draft logs of Figure 8. These logs are provided in final form in Appendix A.

The sand layers create perched water tables when bounded below by a till or silty clay layer of lower permeability. These perched water tables exit at the bluff face as intermittent and perennial seeps and were monitored in the field by Chase and Kehew. Studies (Chase et al. 1999a, 1999b) have shown that these perched water tables often create unstable bluff conditions during intense rain, winter freeze, or spring thaw of the groundwater. A cross section of MPS developed by Chase (Figure 9) shows where seeps have been observed upon exiting the bluff slope. These seeps and others also are noted on the contour map of MPS (Figure 10). With regard to this investigation, MPS has been the most studied and monitored of the three sites; $116^{\text {th }}$ Avenue, the second; and MPN, the least.

\section{Description of bluff at MPS}

The height of the bluff is approximately $90 \mathrm{ft}$ above the lake water level (Figure 9). The demonstration site is approximately $500 \mathrm{ft}$ long and 4.5 miles north of South Haven. The elevation at the top of the bluff is approximately $665 \mathrm{ft}$ at MPS (STS 2005).

MPS has a reasonable volumetric balance of sand and clay layers, as shown in boring log ALG-02-01 (Figure 8 and Appendix A). Clay layers are both diamicton and lacustrine. There is a relatively thick (about 30-ft) layer of upper diamicton, below which lies $15 \mathrm{ft}$ of lacustrine clay, below which are about $34 \mathrm{ft}$ of sand with lacustrine clay layers, one of which is a dominant clay layer about $10 \mathrm{ft}$ thick. Beneath this 34-ft layer lies lacustrine clay to below lake level. The in-place layers are nominally flat, behind the slumped bluff face. 


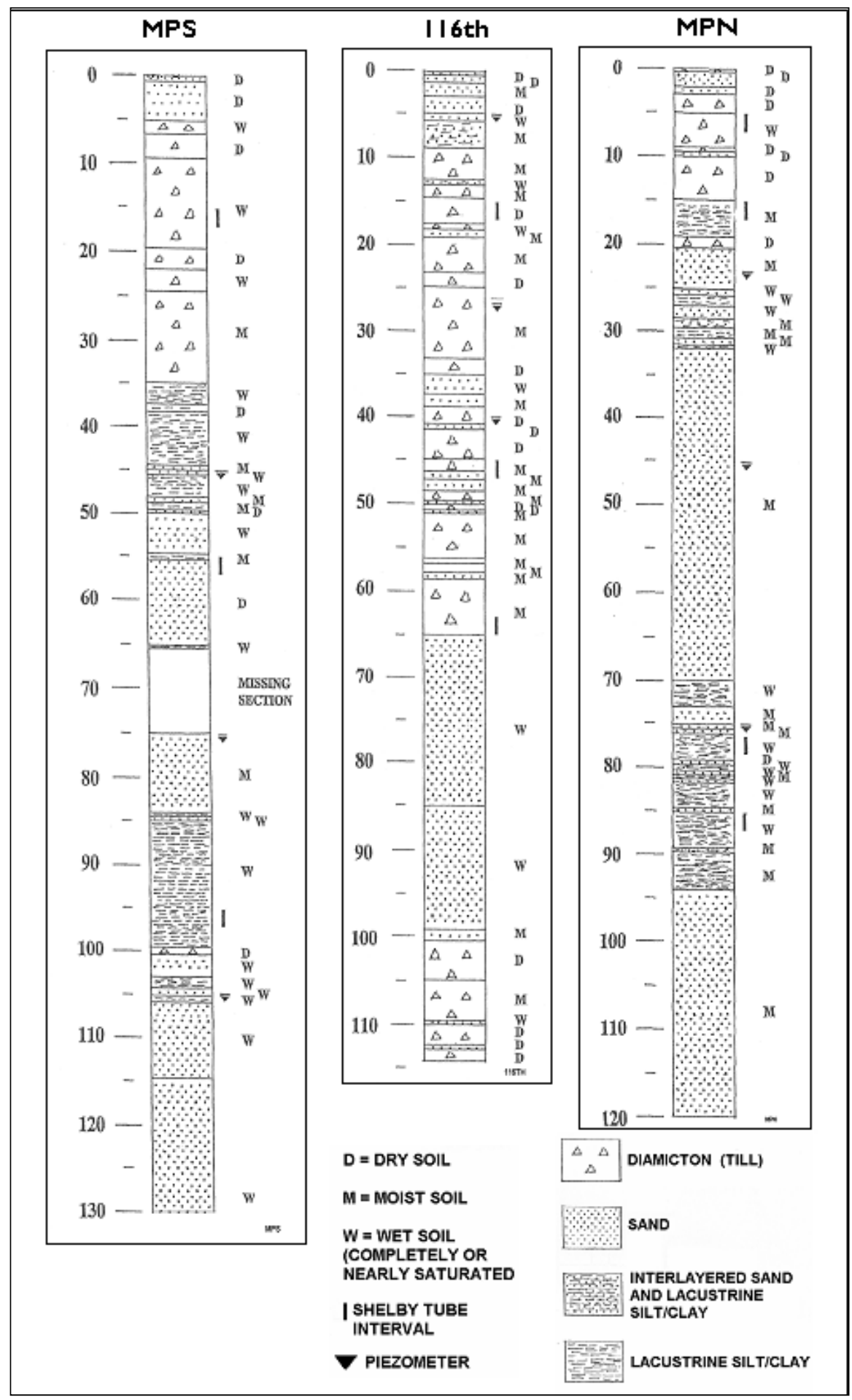

Figure 8. Geologic logs of rotosonic borings, from left, ALG-01 (MPS), ALG-02 (116th), and ALG-03 (MPN). Installed vibrating wire piezometers (VWPs) in each boring, 2004 (geologic interpretation by Ronald B. Chase). 

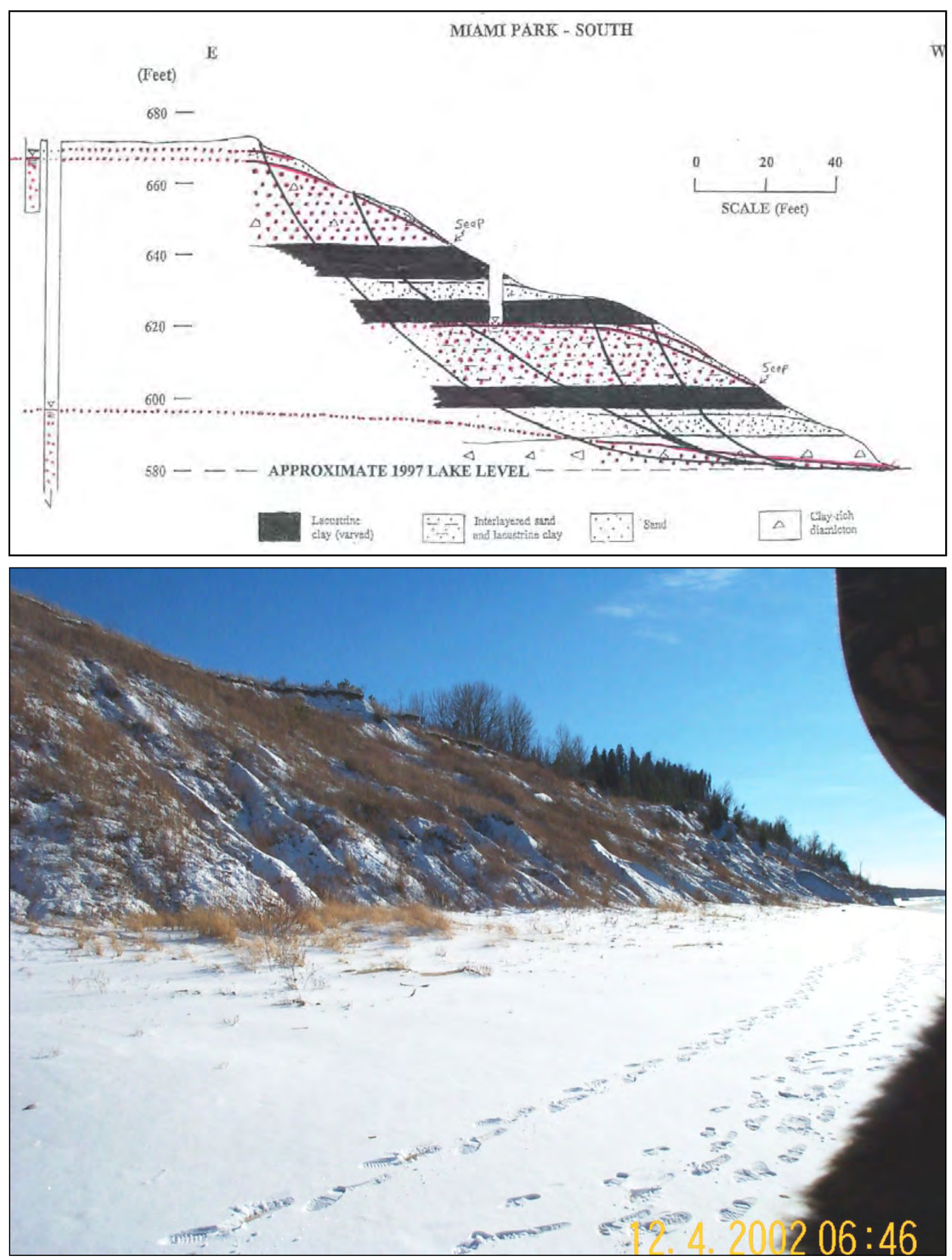

Figure 9. Model cross section, top, (by Ronald B. Chase) showing groundwater seeps and interpreted failure slip surfaces, with respect to bluff stratigraphy, bluff height, and above average 1997 lake level (Chase 2003, personal communication); bottom photo, MPS bluff in winter 2002. 


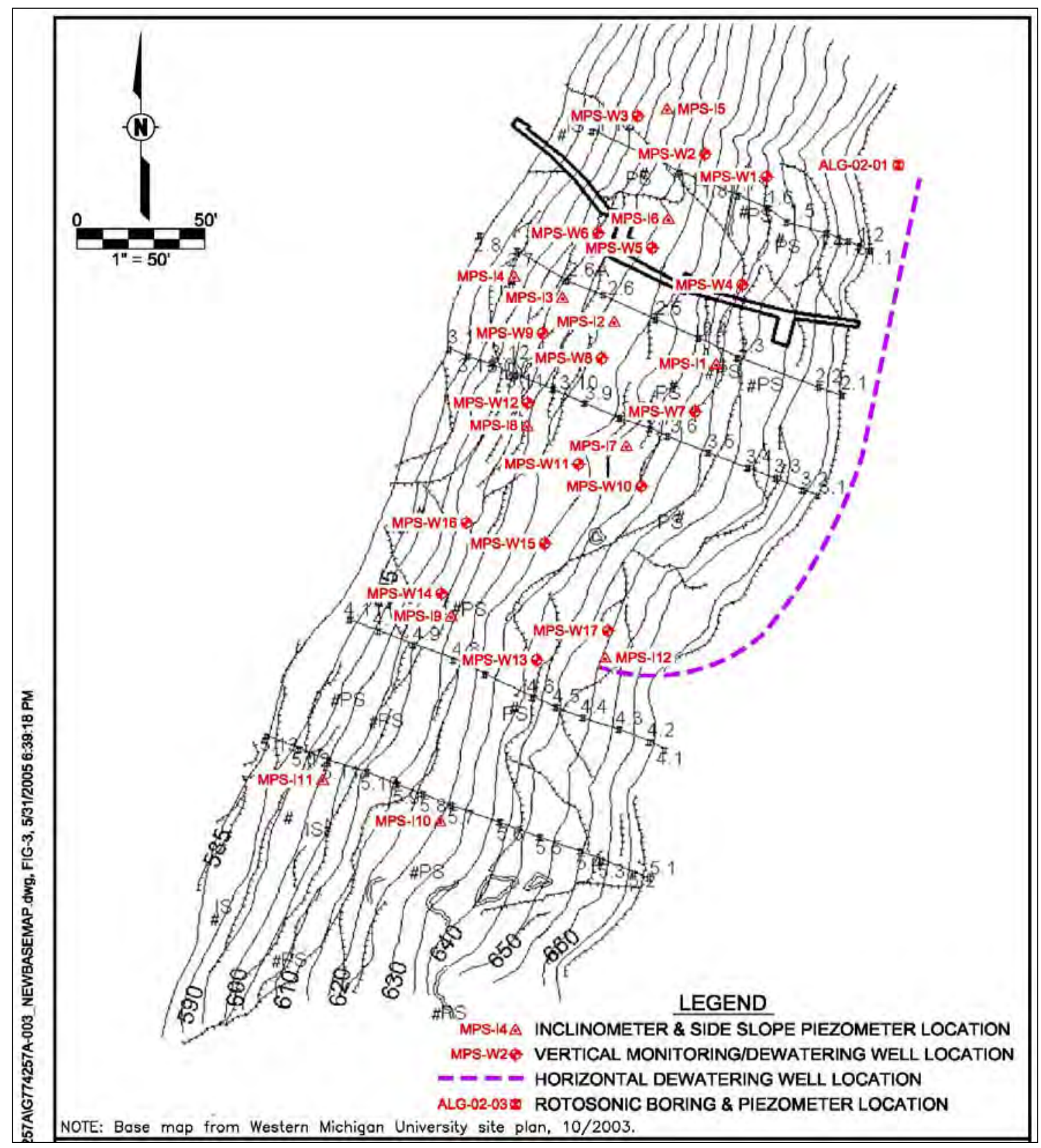

Figure 10. MPS site plan view showing locations of survey lines, monitoring instruments, and wells (after STS 2005; contour map by Ronald B. Chase).

Three borings were advanced by Montgomery in 1996, to install three open standpipe piezometers. The standpipes were terminated at depths of 20, 85, and $130 \mathrm{ft}$. Water levels were monitored in these standpipes from 1996 to 2004 by Montgomery (1998) and Chase et al. (2001a, 2001b). The deepest piezometer was below lake level, while the middle piezometer was slightly above lake level. Water levels in the deeper piezometer were observed slightly higher than water levels in the middle piezometer (Figures 9 and 15). 

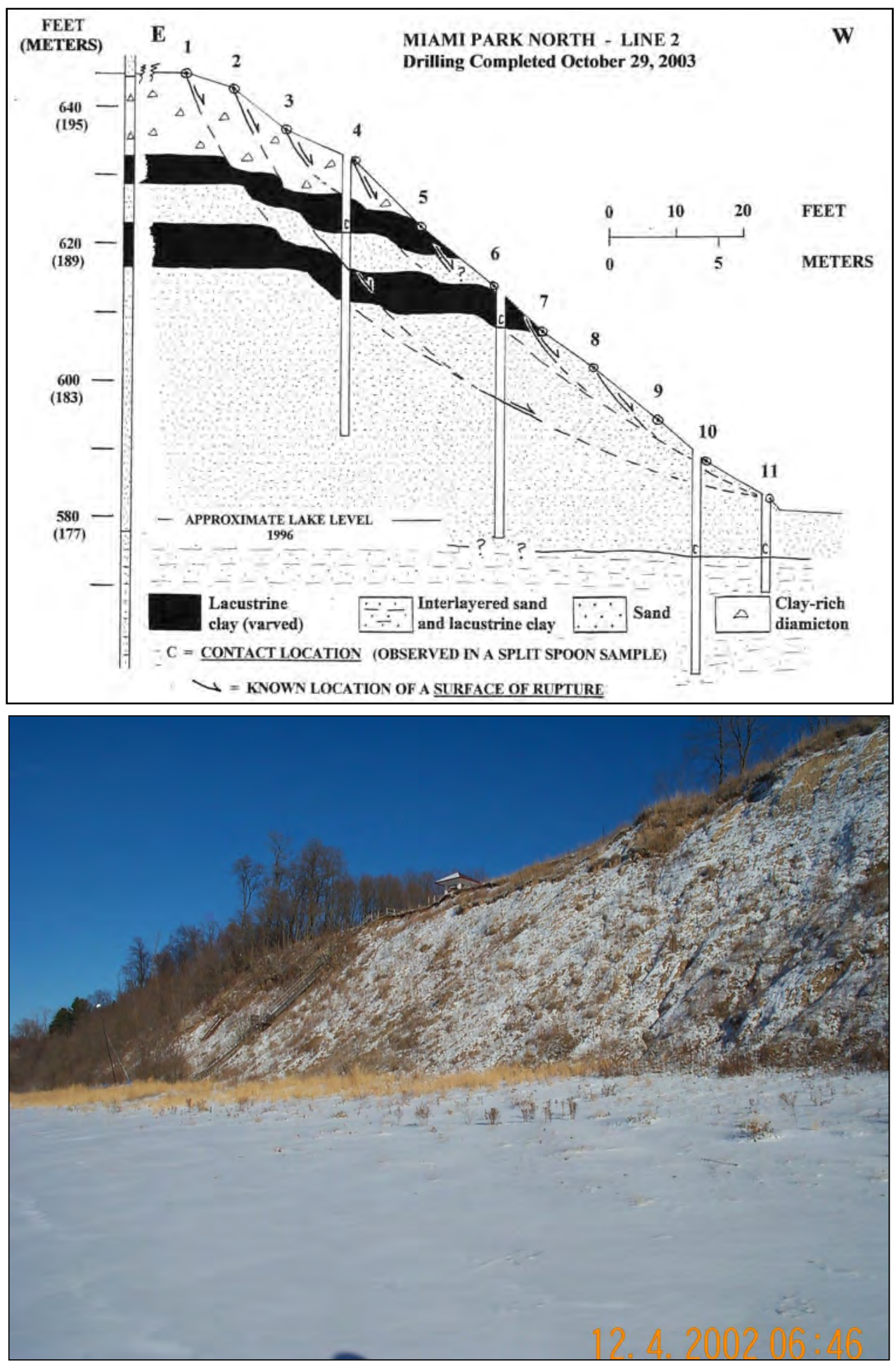

Figure 11. Cross section, top, for MPN to show height of bluff (by Ronald B. Chase); bottom photo, bluff at MPN in 2002. 


\section{Description of bluff at MPN}

The height of the bluff is approximately $65 \mathrm{ft}$ (Figure 11). The elevation of the top of the bluff is approximately $645 \mathrm{ft}$ at MPN (STS 2005). Like MPS, the site is approximately $500 \mathrm{ft}$ long and 4.6 miles north of South Haven. The plan view of the site is given in Figure 12.

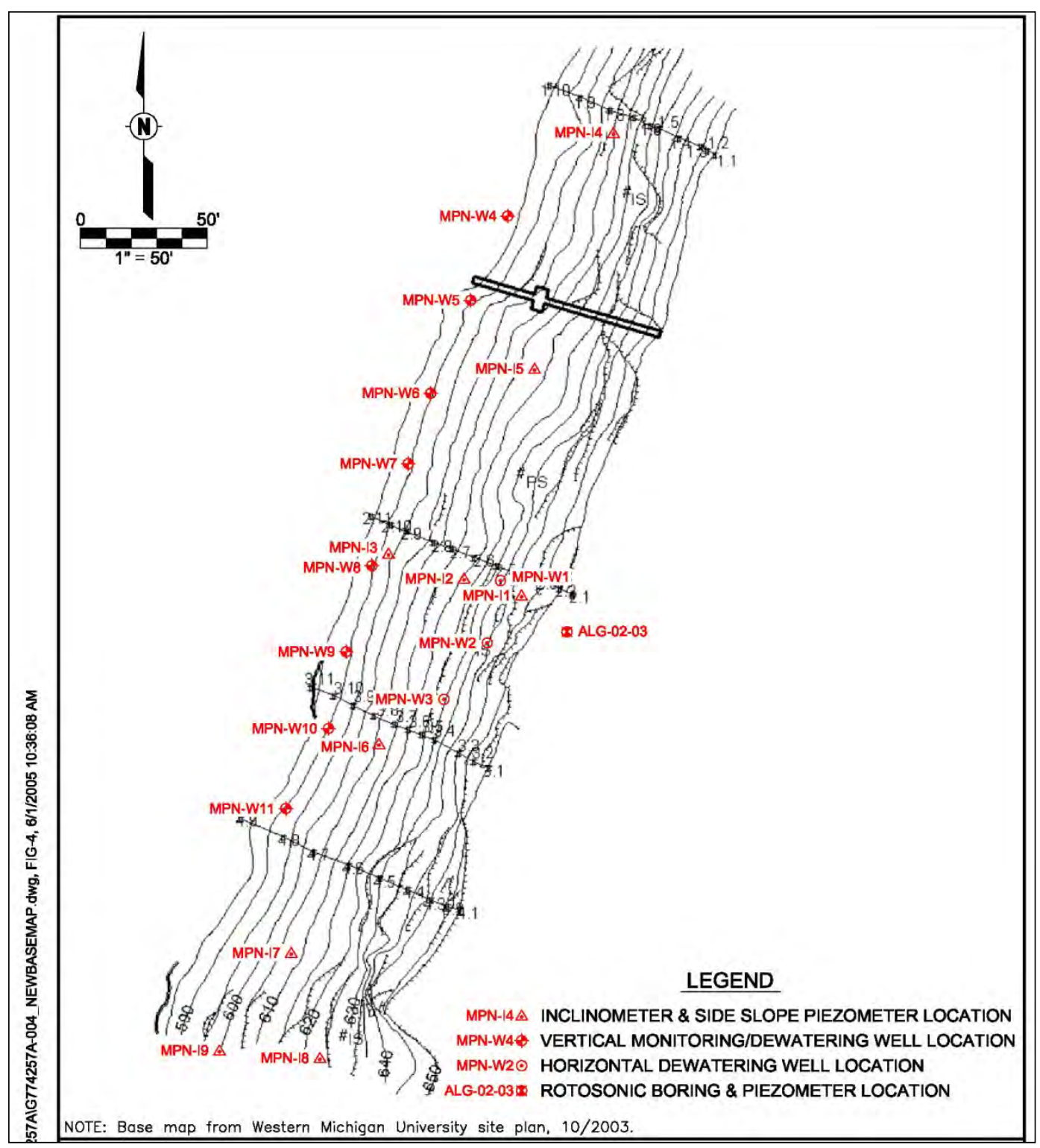

Figure 12. MPN site plan view showing locations of survey lines, instruments, and well locations. Perrenial Seeps (PS) locations identified (after STS 2005, contour map by Ronald B. Chase).

The bluff is mostly sand with very thin clay layers, except near the top of the bluff where clay is significant. Clay layers are both diamicton and lacustrine. Figure 8 includes a general boring log (ALG-02-03) by Chase that illustrates 
the undisturbed stratigraphy of the bluff at MPN. The upper bluff is interlayered sand and diamicton (mostly diamicton) for $15 \mathrm{ft}$, below which are $5 \mathrm{ft}$ of lacustrine clay, below which are $5 \mathrm{ft}$ of sand. Under the sand are $7 \mathrm{ft}$ of interlayered lacustrine clay and sand, below which lies $38 \mathrm{ft}$ of sand that extends to the base of the bluff. Lacustrine clay is at about lake level. The inplace MPN stratigraphic section dips to the north by about 2 or $3 \mathrm{deg}$.

\section{Description of bluff at $116^{\text {th }}$ Avenue}

The height of the bluff is approximately $60 \mathrm{ft}$ above the lake water level (Figure 13). The 116th site is approximately $100 \mathrm{ft}$ long and 9 miles north of South Haven. The elevation of the top of the bluff is approximately $635 \mathrm{ft}$. The plan view of the $116^{\text {th }}$ site is shown in Figure 14.

The bluff is composed primarily of gray, silty diamicton, except for a sand layer defined from 33 to $41 \mathrm{ft}$. Figure 8 includes a general boring log (ALG-02-02) that illustrates the inferred undisturbed stratigraphy of the bluff at 116th. Grey diamicton is present from 41- to 57-ft depth, followed by another sand layer at near lake level from 57 to $68 \mathrm{ft}$ (Montgomery 1998). Here, the clay fraction of the bluff appears to be primarily diamicton. The in-place stratigraphy is nominally flat. Like MPS in 1996, three borings were advanced at 116th to three depths, 42, 64, and $114 \mathrm{ft}$, below ground surface, and standpipes were installed. The piezometric levels from these three depths were measured (Figure 15) by Montgomery from 1996 to March 1998.

\section{Soil properties (MPS, MPN, 116 ${ }^{\text {th }}$ Avenue)}

Four separate geotechnical investigations and laboratory testing programs were conducted for the Allegan County sites. Lab tests were performed on site soils for the purpose of identification of stratigraphic boundaries and properties. The first testing program was directed by Montgomery (1998) and included sieve analyses, index properties, Atterberg limits, unconsolidated-undrained (UU) shear strengths, and consolidatedundrained (CU) shear strengths. These tests were conducted at ERDC's Waterways Experiment Station, on samples obtained from MPS and 116th. The samples were collected from the borings drilled for the standpipe piezometers at MPS and 116 th Avenue.

Montgomery (1998) concludes that the index properties and shear strengths show a logical division of the bluff soils into three litho-mechanical units. The gray, lower till (Ganges) is strong and overconsolidated. The lacustrine 

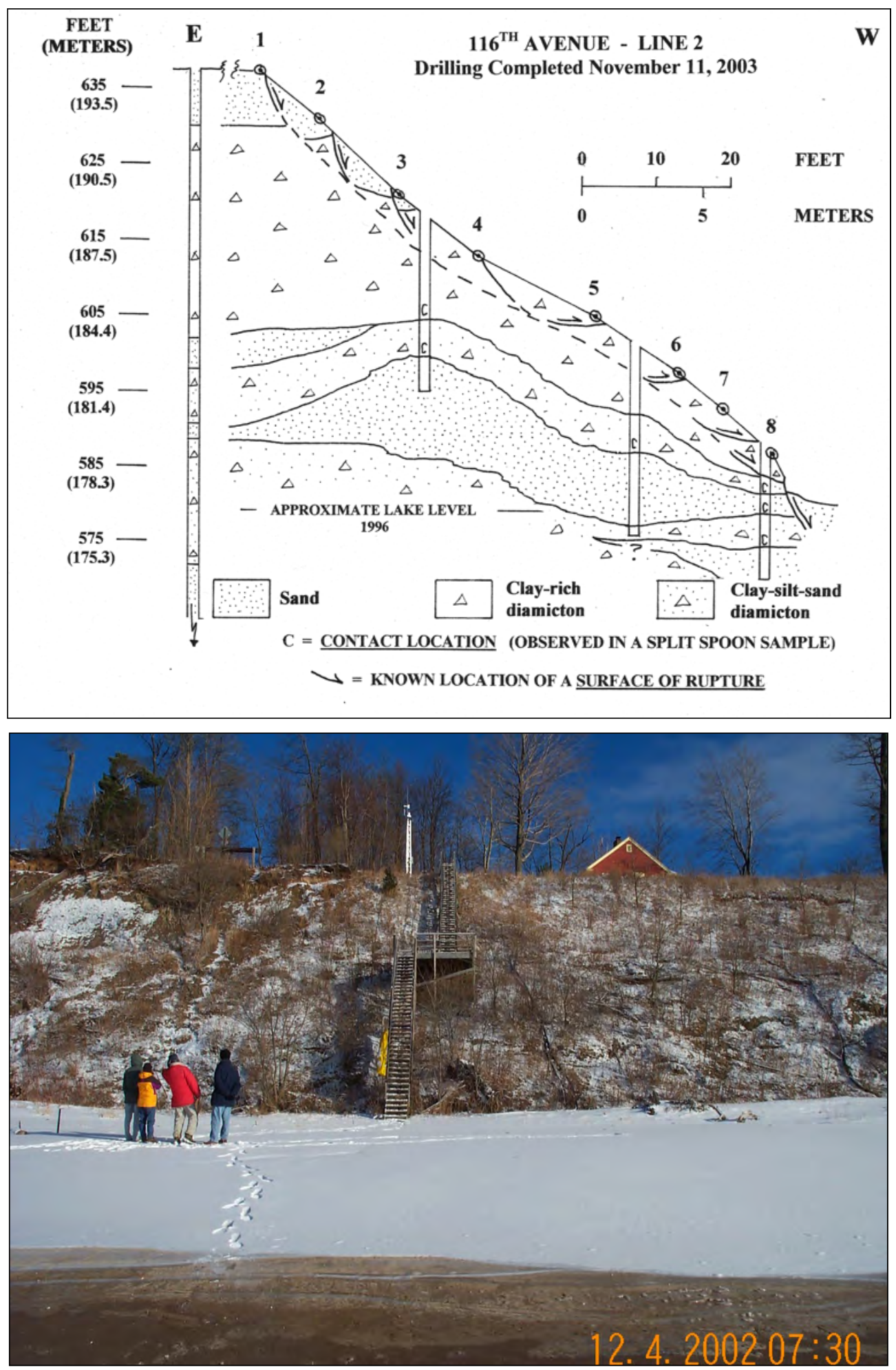

Figure 13. Cross section, top, of 116th showing height of bluff above 2003 average lake level at 176 m (577 ft) (by Ronald B. Chase); bottom photo, site visit in December 2002. 


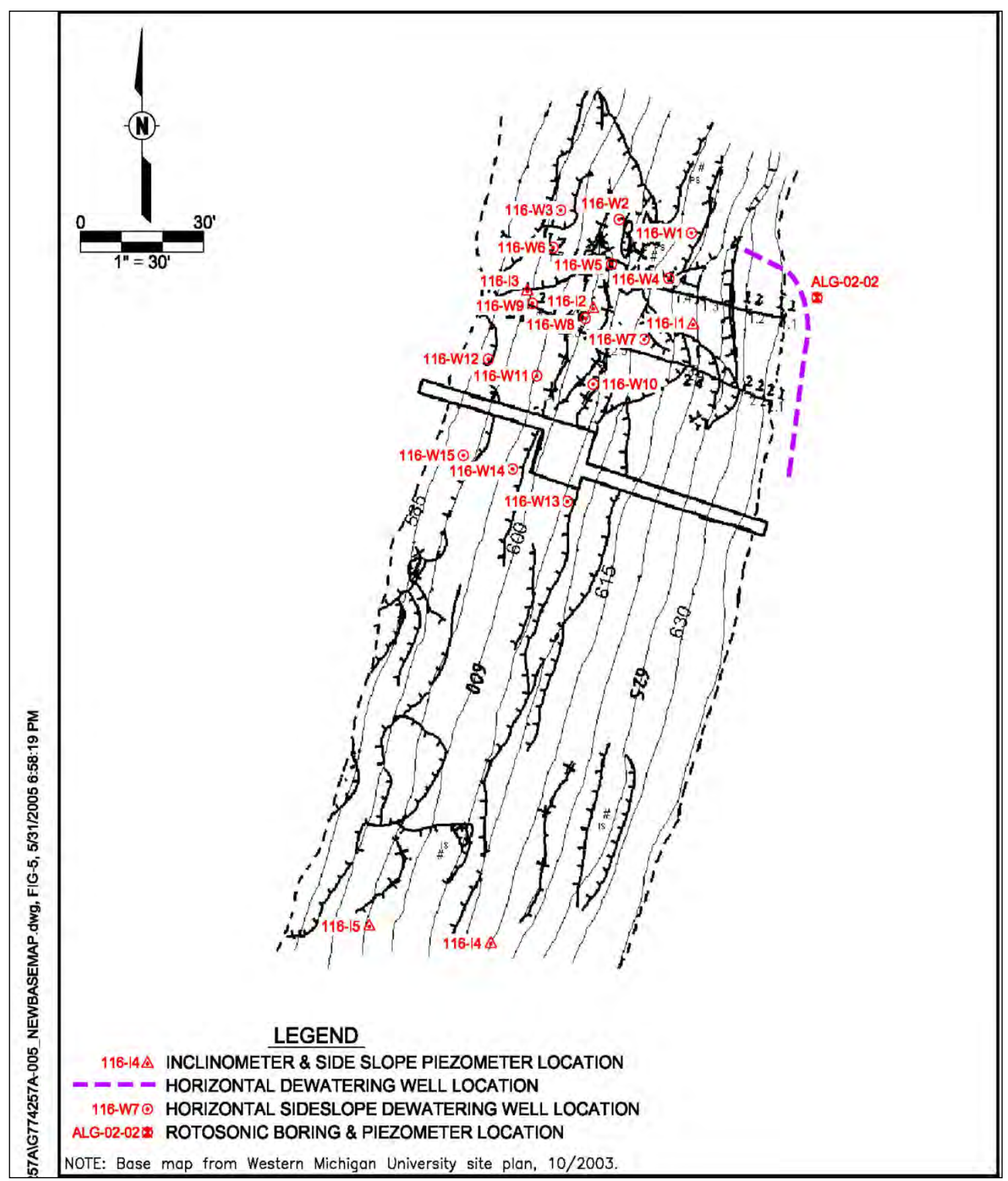

Figure 14. Plan view of 116th site showing contour map with instrument and well locations (after STS 2005; contour map by Ronald B. Chase). 


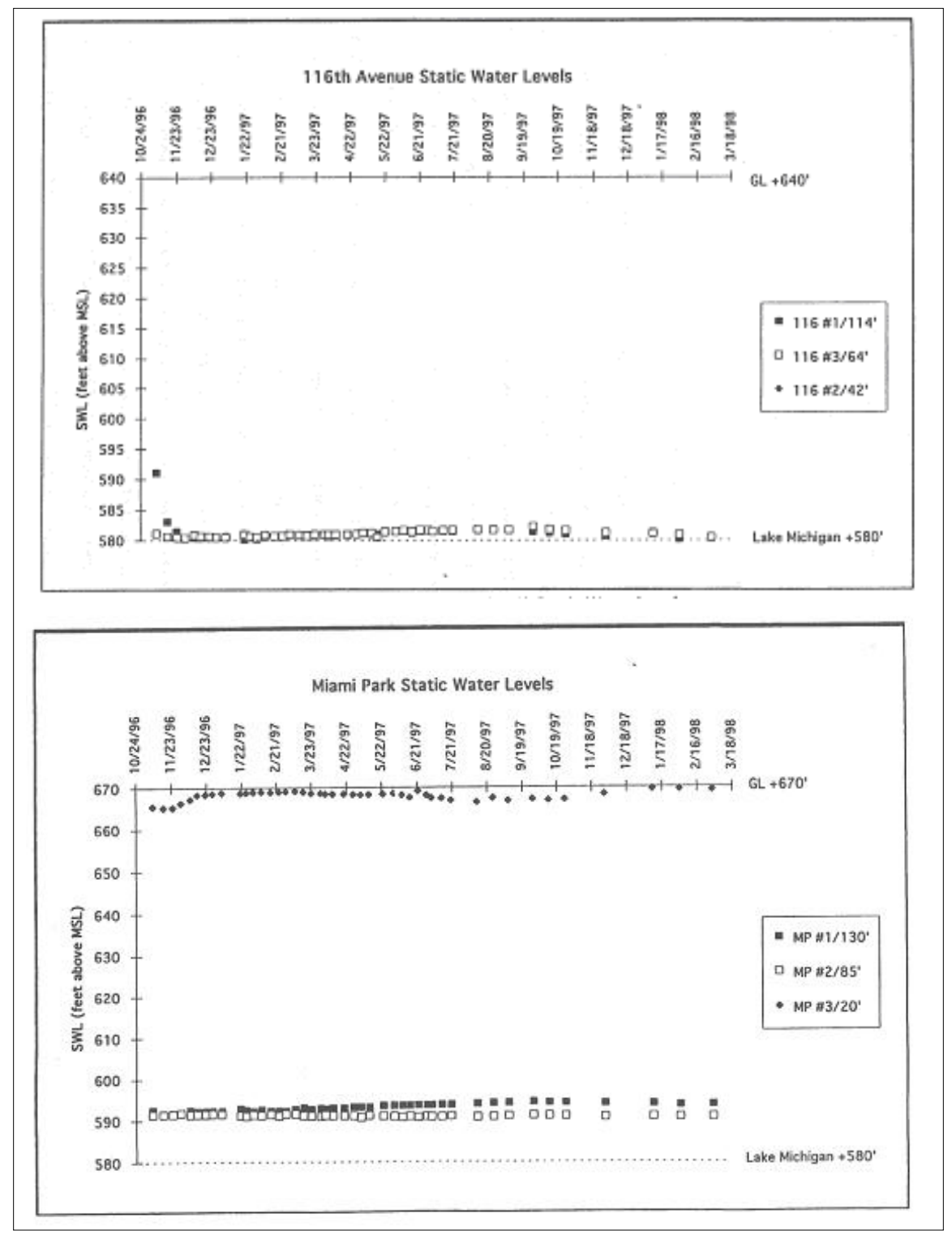

Figure 15. Piezometric readings (after Montgomery 1998).

silt/ clay is weak, normally consolidated, and flows readily under load. The gray-brown upper till (Saugatuck) demonstrates intermediate mechanical properties. The sand represents a fourth litho-mechanical unit that was not tested previously because an undisturbed sample could not be collected (Montgomery 1998). Overall, the lacustrine clays exhibited strain softening during CU testing, while the tills exhibited strain hardening.

The second (2003) and third (2005) testing programs were directed by Chase and performed by STS Consultants, Ltd. In 2003, soil tests were conducted on samples collected during the installation of bluff-top, piezometer wells at MPS, MPN, and 116 ${ }^{\text {th }}$ (ALG-02-01, ALG-02-03, and 
ALG-02-02, respectively). These wells were drilled with a rotosonic rig, and each was logged with an analog, natural-gamma tool. After the boreholes were gamma logged, the piezometer intervals were chosen. Each rotosonic well holds three VWPs. Laboratory tests included moisture content, sieve analysis, and Atterberg limits. Eight CU triaxial and eight permeability tests were performed on cohesive soil samples collected with 3-in., Shelby tubes. Estimates of unconfined compressive strengths were determined on cohesive soil samples by calibrated penetrometer testing (STS 2003). A summary of the 2003 STS testing is in Appendix B. Also in Appendix B is a summary of the piezometer installation details.

The third testing program (STS 2005) focused on soil samples collected during installation of pumping wells and various monitoring equipment. Tests were conducted to determine particle sizes, index properties, Atterberg limits, hydraulic conductivity, and consolidated and undrained shear strengths. These tests include samples from each site (MPS, MPN and, $116^{\text {th }}$ ). Laboratory results are not summarized, rather test reports are in Appendix C. The sampling and testing confirmed previous conclusions regarding general soil types at each site. Soil property tests also were in agreement with previous studies.

\section{MPS}

Based on the results of the soil borings (MPS-W1 to MPS-W17; MPS-I1 to MPS-I12, and MPS-P1 to MPS-P12), the surface is underlaid by interbedded deposits of silty clay, silt, sand, and silty sand.

\section{MPN}

Based on the results of the soil borings (MPN-W1 to MPN-W11; MPN-I1 to MPN-I9; and MPN-P1, MPN-P2, and MPN-P9), the surface is underlaid by deposits of sand and silty sand and interbedded silty sand and clay.

\section{6th Avenue}

Based on the results of the vertical soil borings (116-I1 to 116-15; 116-P2; and 116-P5), the surface at most locations was covered with a thin \pm 6 -in. layer of topsoil. The topsoil was underlaid by deposits of brown and gray silty clay with varying amounts of silt, fine to coarse sand, and gravel. 
Results from the 2005 soil strength tests have not been analyzed fully. However, trends show that the lower clay-rich till near beach level is overconsolidated. The lacustrine silt clay, located primarily in the midsections of the bluffs, is normally consolidated. The upper clay-rich till is normally to overconsolidated.

The fourth laboratory testing program was completed by WMU graduate students in 2007, but details have not been published. These tests included the previously mentioned tests conducted by STS, but focused on shear testing of the project sands. This testing was conducted by WMU graduate student Amanda Brotz. The reader is referred to the Montgomery (1998) and STS $(2003,2005)$ reports for testing details. 


\section{Bluff Stability: Previous Studies and Technology}

Bluff recession investigations along the Great Lakes have been conducted since the late 1800s (Andrews 1870). One of the most comprehensive involved field-mapping and characterization of the entire shore in terms of lithology and type (Powers 1958). The study compared early (1831 for Allegan County) U.S. government township surveys to 1957 re-surveys and calculated average bluff recession rates at 134 stations; seven stations were in Allegan County. The average rate of recession at Allegan County ranged from 1 to $2 \mathrm{ft}$ per year, or 130 to $258 \mathrm{ft}$ over 127years (Powers 1958).

Powers concluded a number of factors controlled or influenced recession, including bluff lithology, morphology, and exposure to lake storms and waves. He stated that the chief factors responsible for the variation in the rate of erosion were "protective structures built by man, storms of unusual severity and fluctuations in mean lake level." Numerous researchers (Seibel 1972; Buckler 1987; Davis 1976; Chase et al. 2001a, 2001b, 2007a, 2007b; Edil and Vallejo, 1980; etc.) have continued the investigation, concentrating on one or more of Powers' findings. These investigations have significantly advanced the knowledge of bluff recession causation and have helped to focus recent studies on the variables of greatest affect.

Investigations of the local area by Chase et al. (1990- 2003) have included detailed characterization of bluffs through mapping of the geology, groundwater surfaces, bluff deformation, and bluff recession. Monitoring and recording of slope movements, piezometric levels, atmospheric conditions, storm events, lake levels, and bathymetry were conducted at the MPS, MPN, and 116th sites. Drilling and sampling of soil materials were performed and piezometers were installed at the sites, as described in the previous chapter. Geologic cross sections were developed using available and subsurface data obtained from the rotosonic core logs and gamma logging. Laboratory testing (STS 2003) of the soils was conducted to determine grain size distribution, compressive strength, and other engineering properties. 


\section{Field mapping: Lithology versus recession}

The 6-mile, geologic profile in Figure 7 was developed from field mapping of the bluffs between Saugatuck and South Haven (Chase 1990). The bluff surface was characterized every $197 \mathrm{ft}$ (60 m) with respect to profile shape, soil layer types and thicknesses, fracture spacings and orientations (Chase 1990), vegetative cover, surface drainage and mass movement conditions, surcharge placement, land use, and type of erosion mitigation structures (Chase et al. 2001a, 2001b).

The profile shown in Figure 7 was divided by Montgomery (1998) into 43 equal reaches. Each reach was classified as mostly sand (greater than 66 percent sand), mostly clay (less than 33 percent sand), or mixed sand/ clay (greater than 33 percent sand and less than 66 percent sand). From 1938 to 1996, comparisons were made between recession rates of each reach and its lithology. Rates were determined through comparison of 1938 and 1996 aerial photographs. The data were plotted as shown in Figure 16. Montgomery (1998) concluded that bluffs with mixed stratigraphy (interlayered sand and clay layers) displayed higher rates of bluff recession than bluffs composed of mostly clay or mostly sand. Short-term data (1989 to 1996) also confirms this correlation, but is not shown by Montgomery (1998).

\section{Monitoring slope movement: Pole-and-cable system}

A pole-and-cable system designed by Chase et al. (2001a, 2001b) was used to monitor slope displacements at three stratigraphically different sites, to test the hypothesis that bluffs of mixed lithology are recessing at a higher rate than bluffs consisting of mostly clay or mostly sand. The sites were representative of mixed, sand, and clay layers (MPS), mostly sand (MPN), and mostly clay (116th). Earlier studies indicated additional factors affecting bluff recession that included Lake Michigan levels, downcutting of the backshore and foreshore of the beach, seeping groundwater from the bluff face, and weather conditions. Each of these factors was correlated in detail to the slope movement data collected using the pole-and-cable system installed at the three sites.

The system consists of a semi-permanent line of fence poles placed down the bluff face in rows parallel to suspected bluff movement. Figure 17 shows a simplified view of the system. A calibrated cable is threaded through an eyebolt at the top of each pole and allows measurement of the pole (translation). Vertical pole rotation is measured with a Brunton compass. 


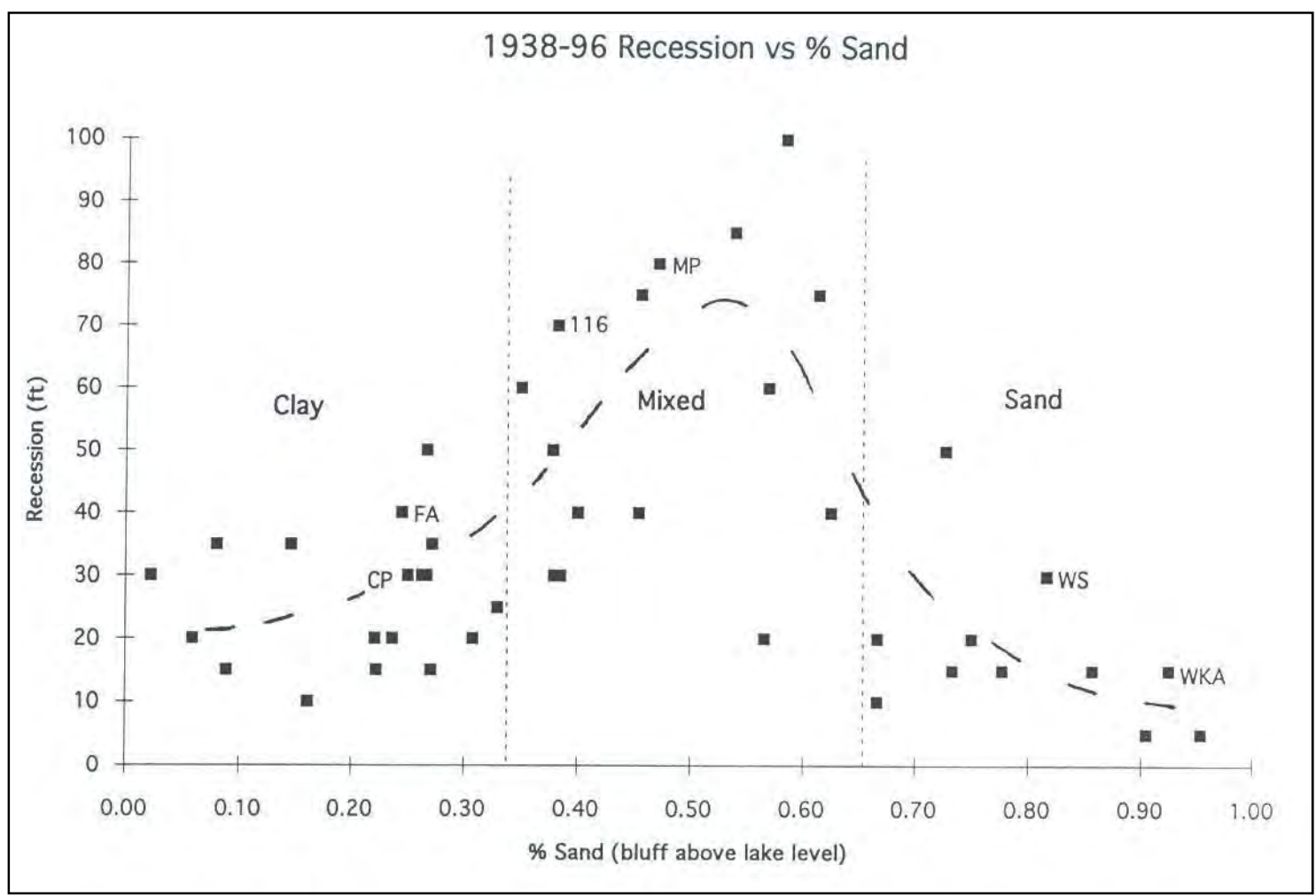

Figure 16. Recession rate versus bluff lithology (after Chase et al. 2007b)

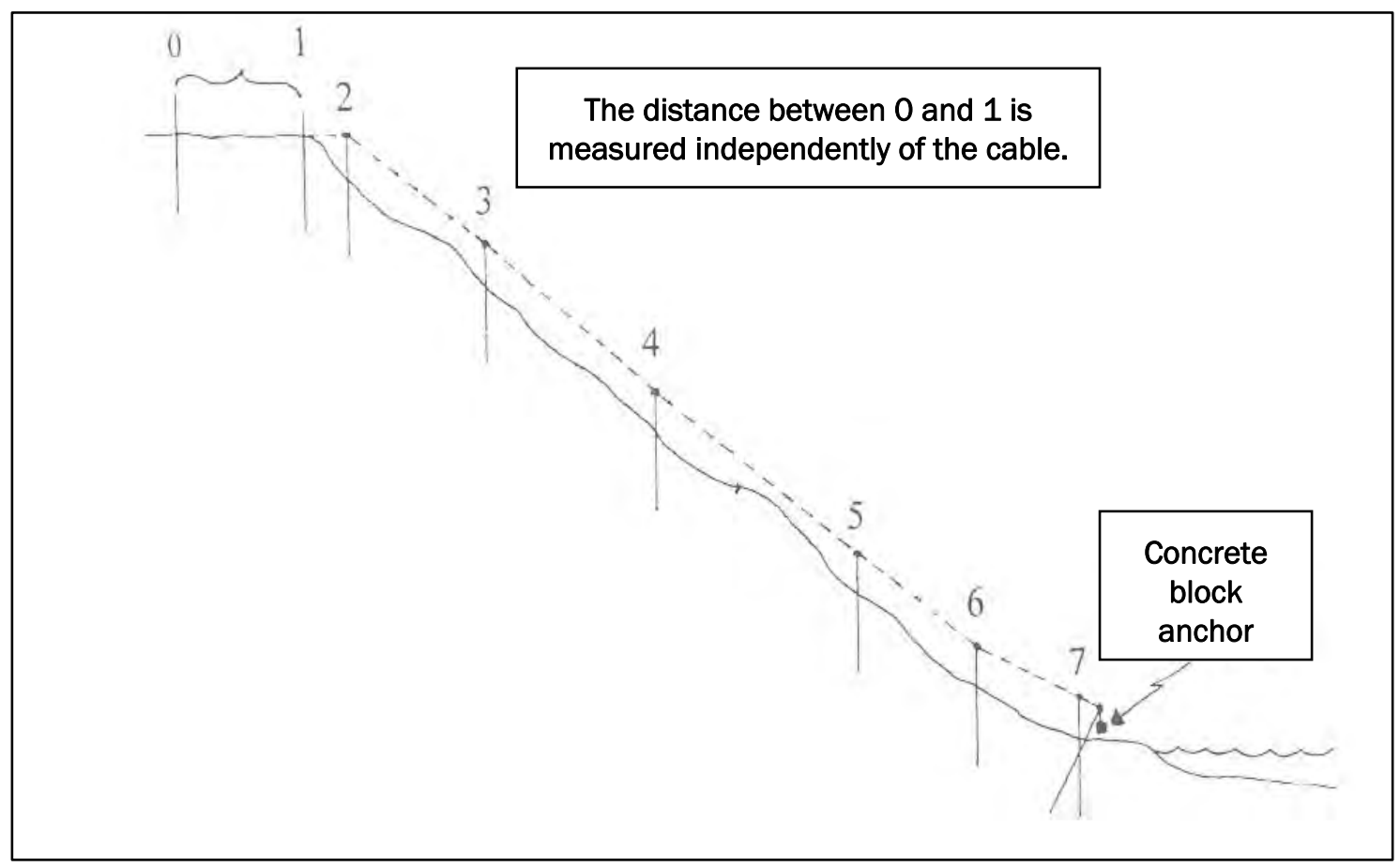

Figure 17. Example of pole-cable survey system. Poles should be anchored in clay layers (after Chase et al. 2001b). 
Pole-and-cable survey lines developed for the three sites are plotted in plan view on each contour map (Figures 10, 12, and 14). In 1996, four survey lines were installed at MPS, and two survey lines were installed at 116th. In 2001, the study was expanded to include MPN, where three survey lines were installed. Also in 2001, two survey lines were added to MPS. In 2004, one survey line was added to 116th. During the period of 1996 to 2004, the survey lines were inspected every three weeks on average during high movement seasons, and every six weeks during times of little movement.

Each 8-ft fence pole was driven manually into the slope, and its end was positioned in an assumed clay rich layer. Figure 18 is a photograph of the last pole in a survey line with a weight (concrete block) attached to the cable for tension. Figure 19a illustrates the original position of the poles installed at MPS in 1996, while Figure 19b shows the dramatic displacement of the poles from 1996 to 2001. Pole 8 moved almost $50 \mathrm{ft}$ downslope during the five-year period. Poles 9, 10, and 11 have moved completely off the slope and were removed by wave action.
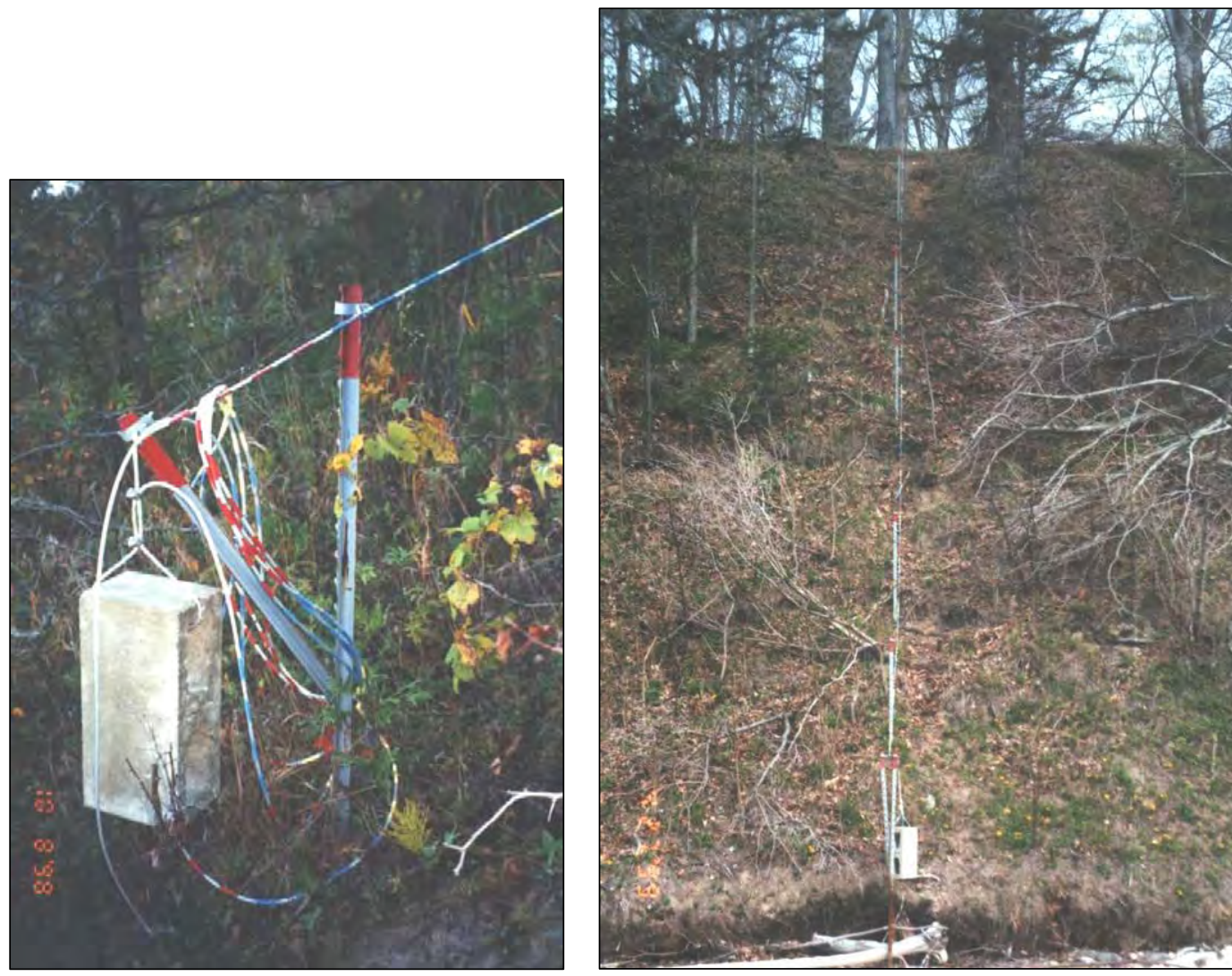

Figure 18. Last pole, left, of the calibrated pole-cable system and concrete anchor, and, right, calibrated cable system shortly after installation at $116^{\text {th }}$ Avenue. 


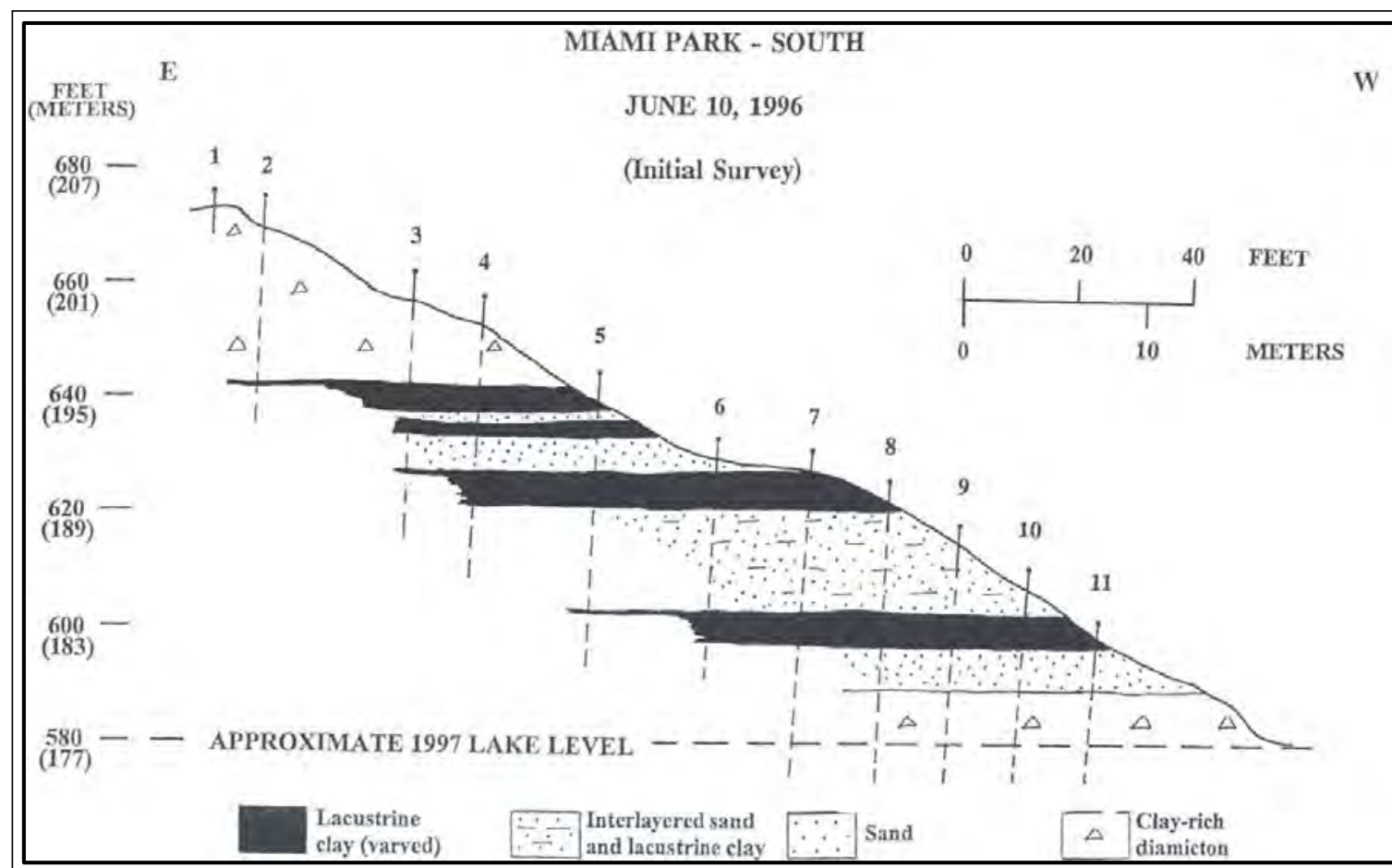

part a

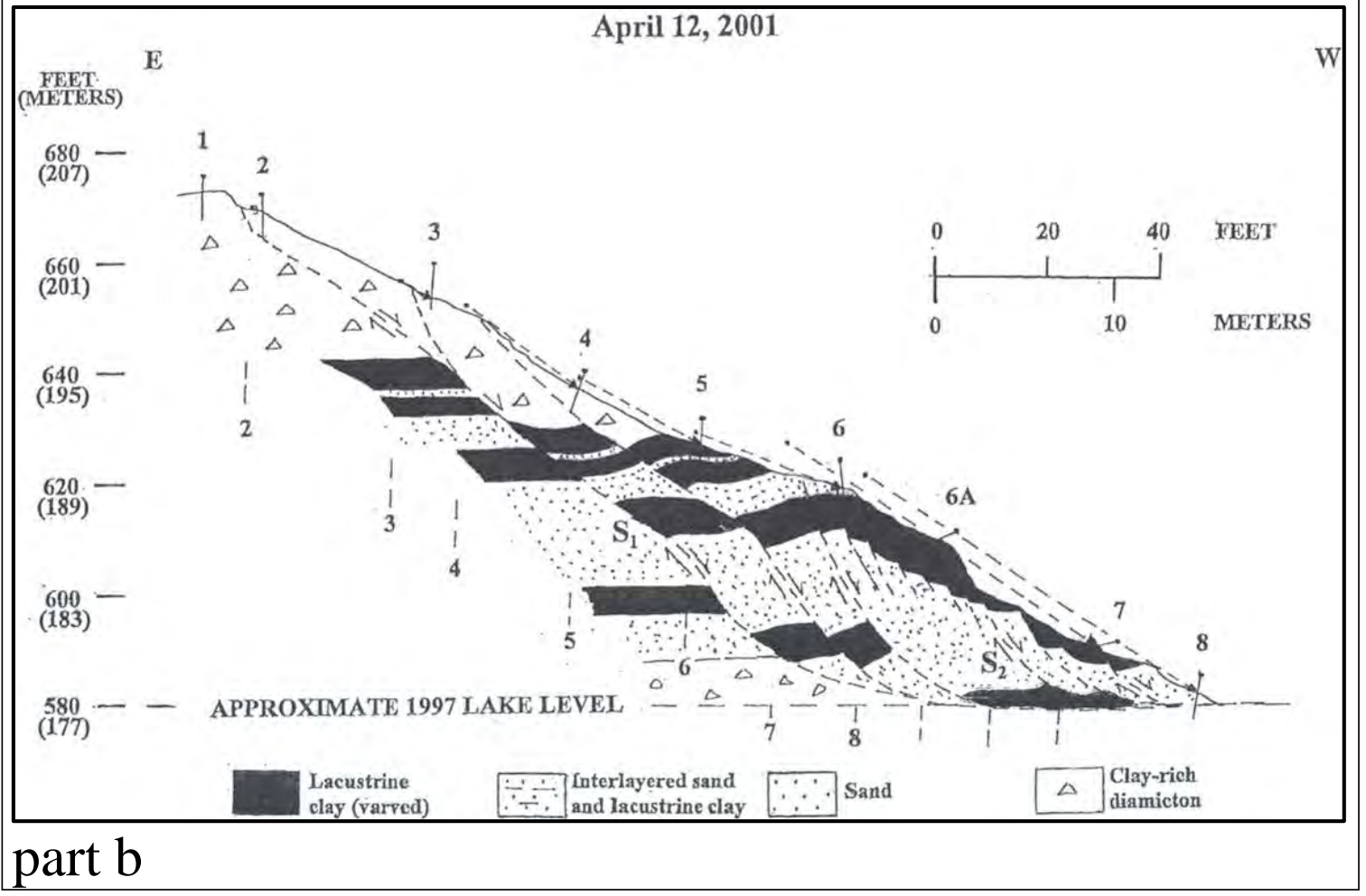

Figure 19. (a) Original position of poles at MPS (after Chase et al. 2001b) and (b) displacement of poles five years later. Cross-section $b$ interpreted by Ronald B. Chase, using the Balanced Cross Section Method (Chase 2003, personal communication). 
Interpretation of subsurface deformation from pole-and-cable measurements

An important benefit of the pole-and-cable system is the ability to interpret the subsurface movement and geometry from the surface movement expressed by the rotation and translation of the poles. By projecting the surface translations and rotations of the survey poles into the subsurface with a series of balanced cross sections (Figure 20), a new geometry is constructed that expresses surface and subsurface distortion resulting from slope failure (i.e., slumping). By constructing an accurate cross section, other studies, such as limit equilibrium analyses and groundwater investigations, can be conducted with confidence. Also, valuable insight to the active failure mechanism(s) is provided when the change in the subsurface geometry can be modeled versus time.

Projecting the surface deformation to the subsurface is accomplished by using the Balanced Cross Section Method. The method is briefly described in Figure 20 and fully described by Chase et al. (2001b). The method traditionally was applied to disturbed sedimentary mountainous terrain (Woodward et al. 1985) but has proved to be accurate at Allegan County (Chase et al. 2001b), as described in the next paragraph.

Figure 19a is an interpretation of the undisturbed structural geology at MPS based on a piezometric well, drilled circa 1996, approximately $75 \mathrm{ft}$ inland from the bluff's crest. Figure 19b (interpreted by Chase) illustrates the progressive slumping of the substrata using the Balanced Cross Section Method. This is tedious work that currently is only accomplished manually.

Figure 21 shows five cross sections along the pole-and-cable survey lines at MPS. These sections, developed from pole-and-cable data, were verified with drilling data in late 2003. The success of the Balanced Cross Section Method in representing the actual subsurface slumping was reported in Chase (2007a). In essence, the depths of the soil and slip contacts from the modeled cross sections closely match the depths discovered during the onsite drilling and logging. The reader is referred to Chase et al. (2007a) for explanation of the statistical comparisons of the modeled-to-actual data.

\section{Historic lake levels}

Average lake levels during the study period of 1996 through 2006 are illustrated in Figure 22. These charts were obtained from the USACE 
Detroit District. These are average monthly water levels and do not show the extreme high-water events that contribute to shore downcutting. However, the general trend shows a decrease in annual lake levels since 1997. The highest annual water elevation during this period was approximately $581 \mathrm{ft}$ in May 1997. The highest annual water levels have decreased since 1997, to $580 \mathrm{ft}$ in 1998, and have stayed below $578.5 \mathrm{ft}$ since 1999. Thus, normal lake levels since 1999 have been approximately $1.5 \mathrm{ft}$ or fewer below the elevation of the bluff toe at MPS.

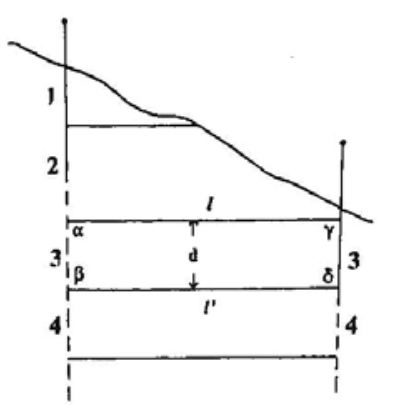

A

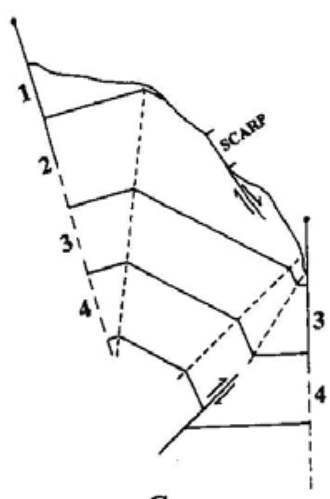

C
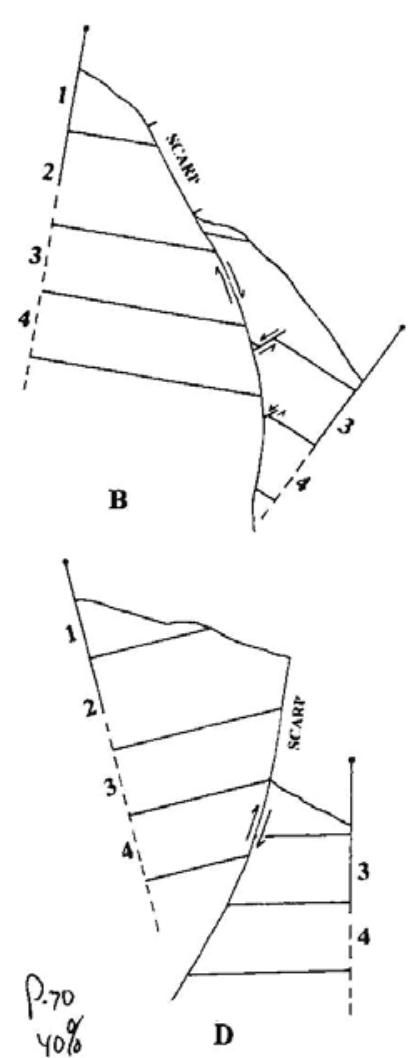

Examples of cross-section balancing methods for two complete and two partial cells in which all original line lengths and angles are maintained (from Chase et al., in press). (A): Two partial cells and two complete cells between poles. For reference cell 3 with thickness $\mathrm{d}$, lengths $l \neq l$, angles $\alpha=\beta=90^{\circ}$, and angles $\gamma \neq \delta \neq 90^{\circ}$ because the two poles were not exactly parallel upon installation. (B): The poles diverge and differentially rotate resulting in a rotational normal fault plus two minor adjustment faults. (C): The poles converge and differentially rotate resulting in a fault propagation structure. Kink bands are shown, but curved fold patterns are permissible also. (D): The same converging poles as in (C) result in an alternative rotational reverse fault interpretation. The choice between balancing methods (C) and (D) is dictated by the shape of the ground surface between poles and the best choice for the balancing of adjacent cells.

Figure 20. Description of the Balanced Cross Section Method (after Chase et al. 2001b). 


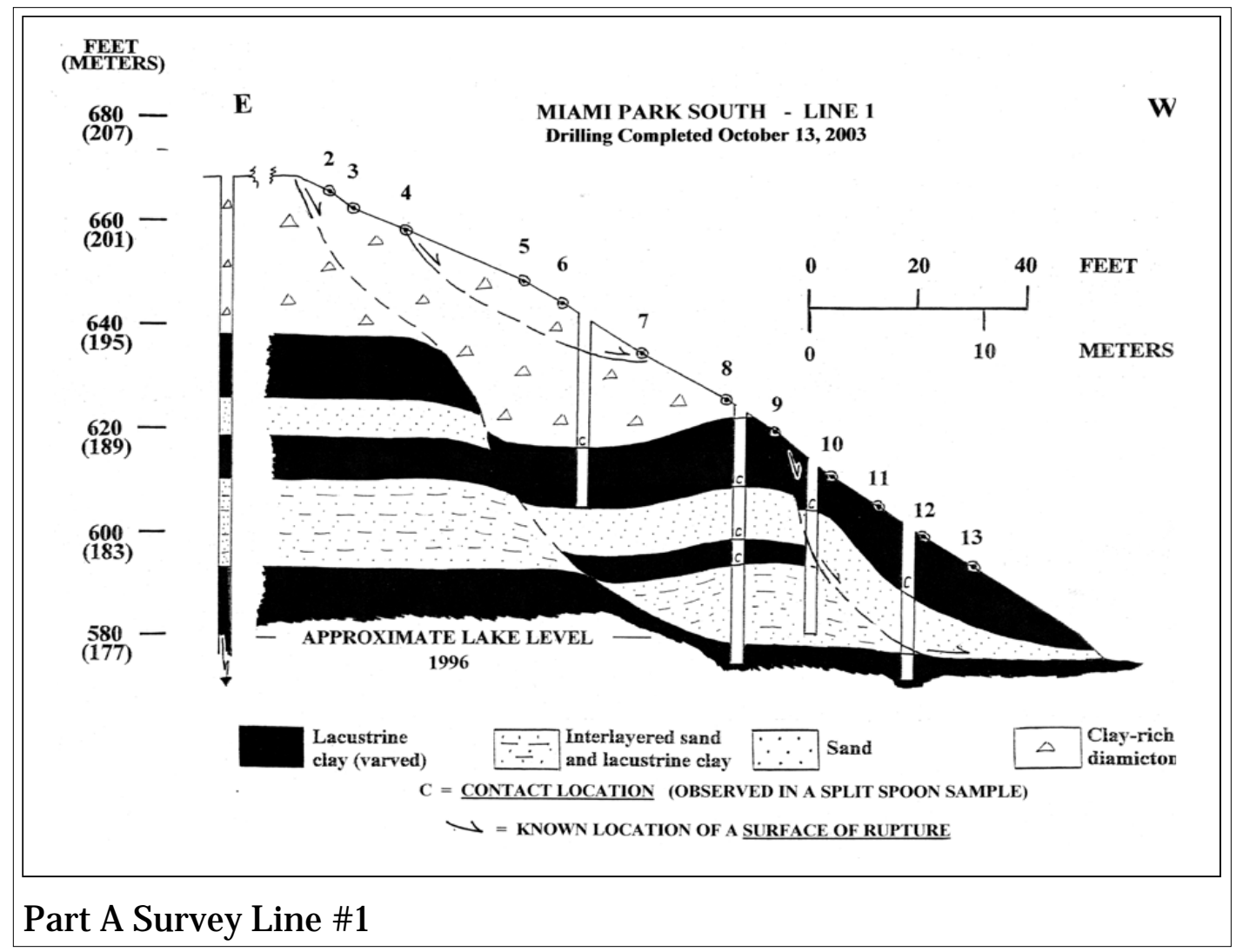

Figure 21. Cross sections developed from drilling and split spoon sampling for the installation of pumps and monitoring equipment in late 2003. Parts A through E show pole-and-cable Survey Lines 1 through 5 , respectively. The geologic layering within the numerical model was constructed based on these cross sections. Lines 1 through 3 are in the dewatered zone of the MPS site. Lines 4 and 5 are in the control section of the MPS site (constructed by Ronald B. Chase).

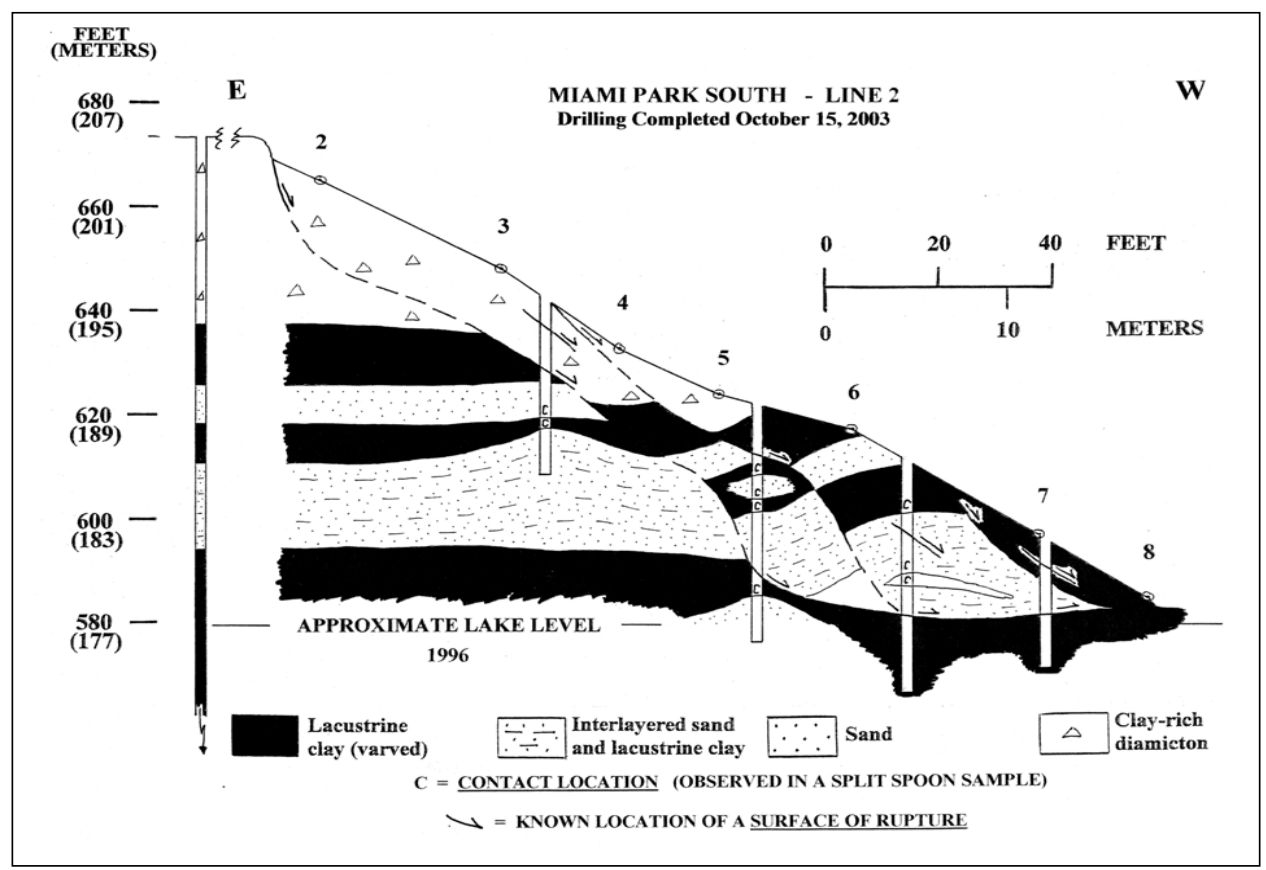

Figure 21 (continued). Part B, Survey Line 2 (by Chase). 


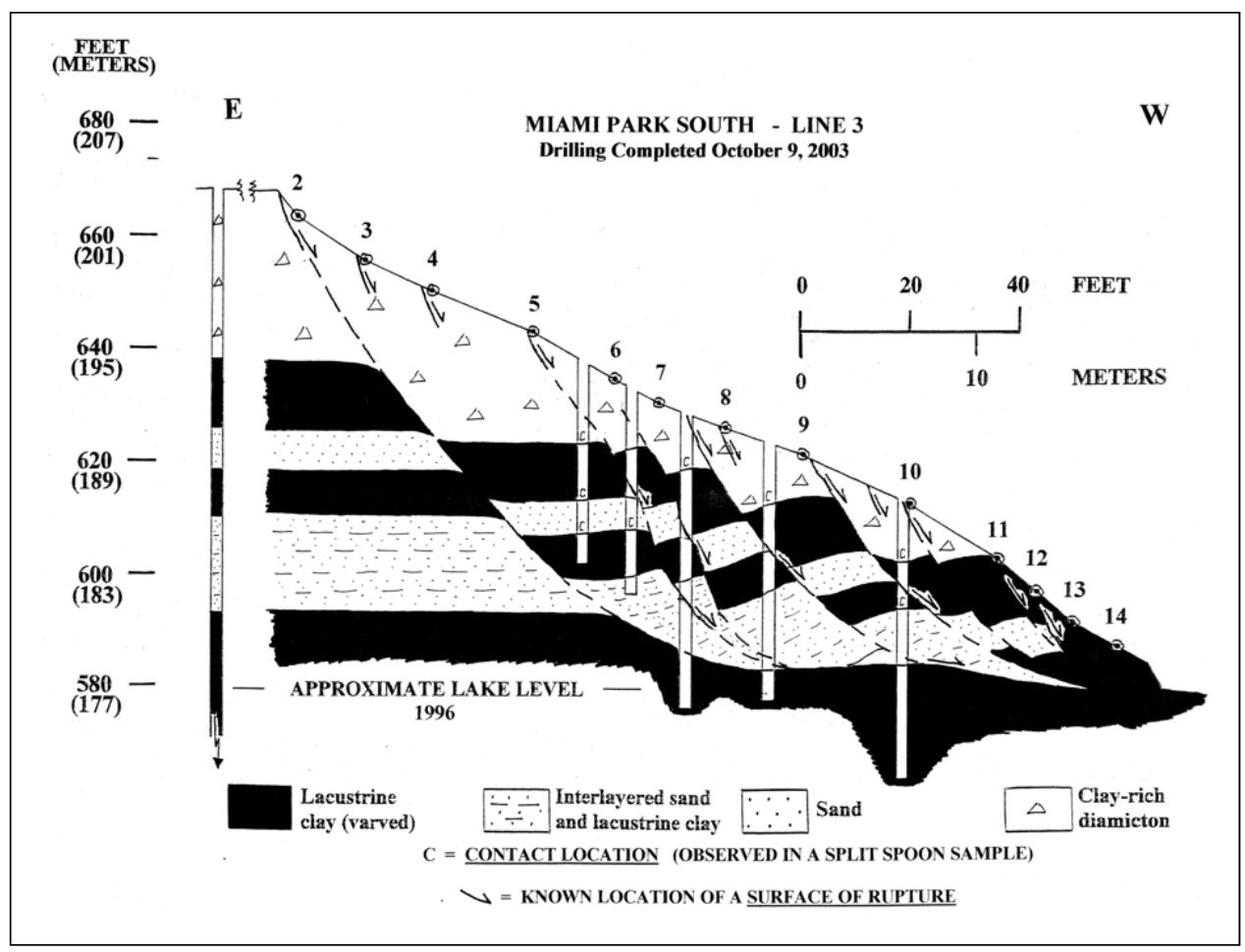

Figure 21 (continued). Part C, Survey Line 3 (by Chase).

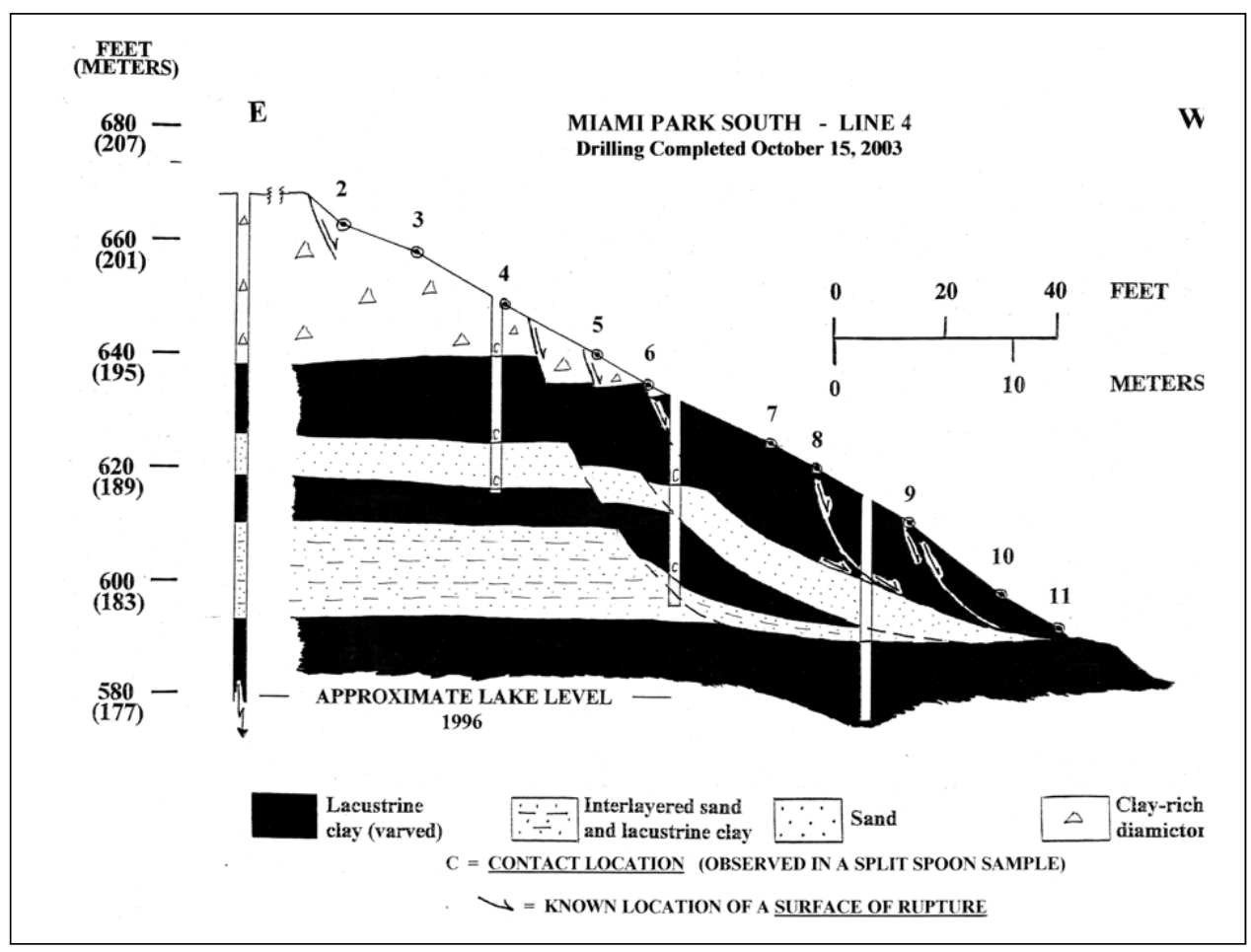

Figure 21 (continued). Part D, Survey Line 4 (by Chase). 


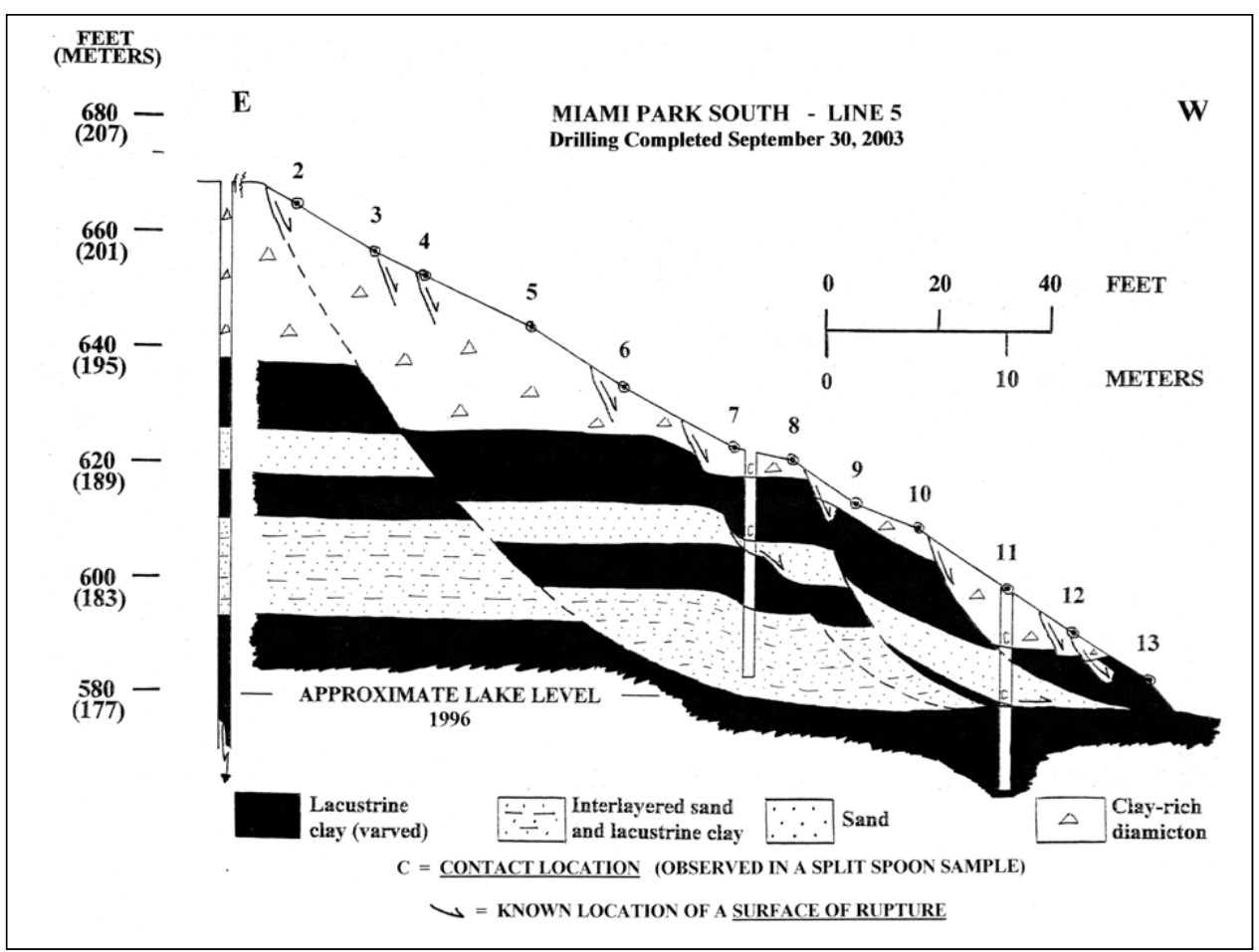

Figure 21 (concluded). Part E, Survey Line 5 (by Chase).

In addition to USACE lake levels, the heights of waves that potentially erode the bluff toes were estimated from observations of toe-cutting erosion events along the shore and, as a guide, temporal correlation with the prevailing wave heights recorded hourly from National Oceanic and Atmospheric Administration (NOAA) Buoy 45007, approximately 45 miles $(72.5 \mathrm{~km}$ ) offshore from the sites (Chase et al. 2007b). Similarly, these wave heights that could reach the base of the bluff have consistently decreased since 1997 to practically null since 2002 .

\section{Nearshore characteristics and bathymetry}

A bathymetric survey was performed in the study area in August 2003. Bathymetry was collected using Scanning Hydrographic Operational Airborne LIDAR (SHOALS) and began approximately $5 \mathrm{~km}$ north of South Haven for a distance of $12 \mathrm{~km}$. The survey extended to approximately $10 \mathrm{~m}$ of depth.

\section{MPS and MPN surveys}

The bathymetry offshore of the two Miami Park sites is shown in Figure 23. The nearshore morphology appears to show three bars. The outer bar is the smallest of the three and is irregularly shaped. The middle bar is wide and 

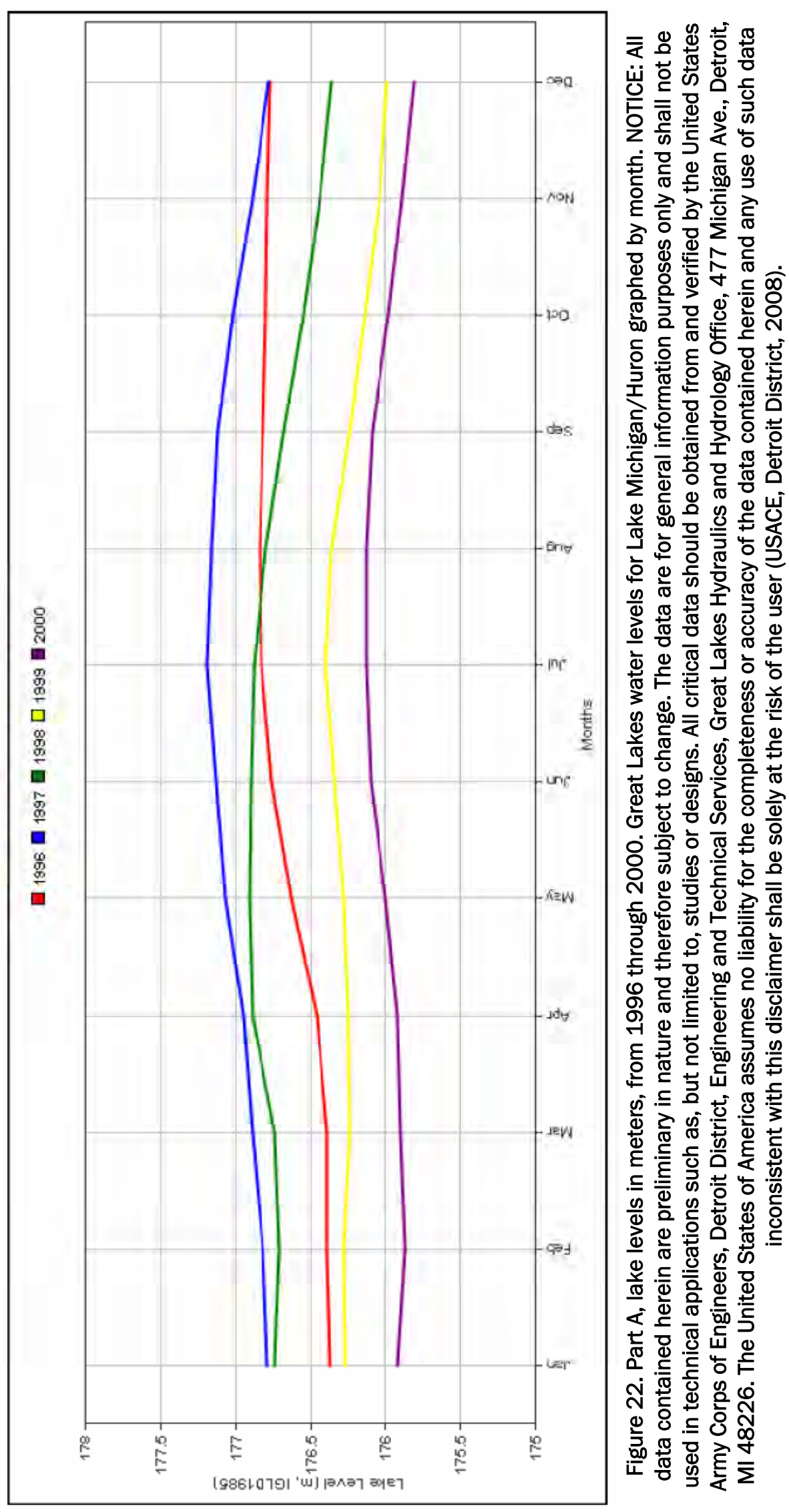
ERDC TR-12-11

34

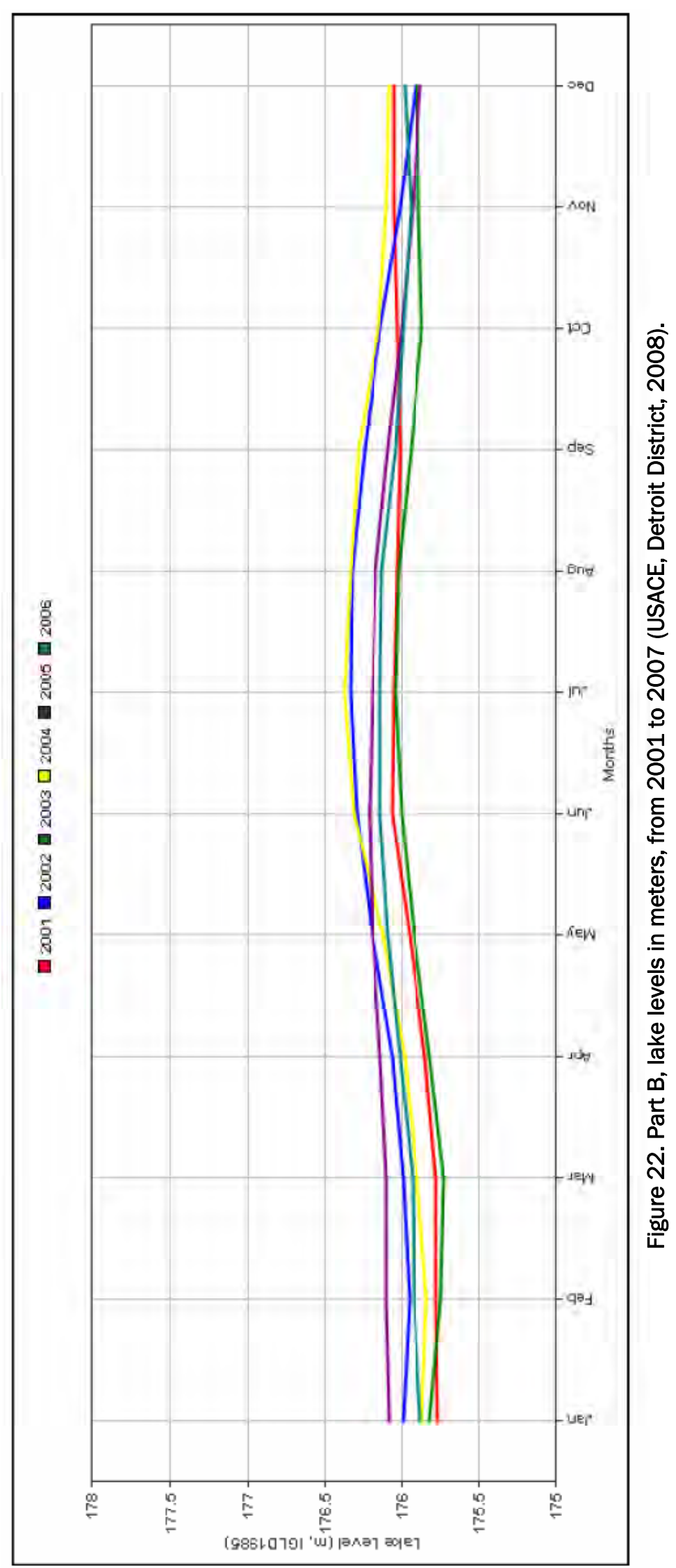




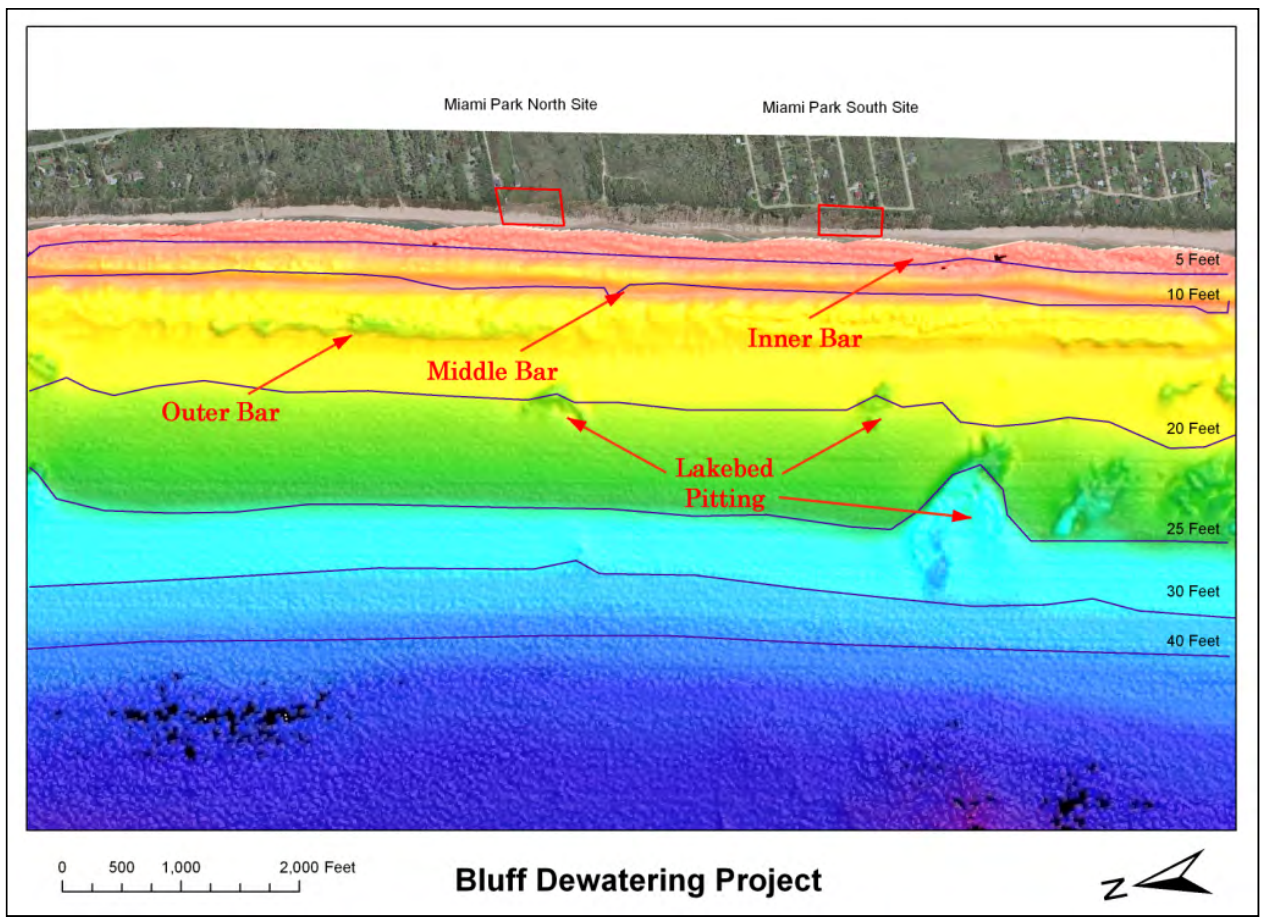

Figure 23. Bathymetry of Miami Park (interpreted by James P. Selegean, USACE, Detroit District).

fairly linear, as is the inner bar. The smooth bed features have been interpreted to represent a sand veneer over a cohesive till. Sand probing with a jet pump has verified the existence of sand on the surface. The areas labeled as lake-bed pitting have been interpreted to be zones in which the bed has scoured. The process that caused this scour only can be speculated but could include the presence of a weaker stratigraphic unit, scour due to a localized thinning of the protective sand layer, or other processes. Verifying the underlying strata could not be done with the sand probe; however, they are likely composed of materials similar to those found in the exposed bluff directly onshore. The stratigraphy of the bluffs is shown in Figure 8. To verify the composition of the underlying strata, borings would have to be done. Based on the bathymetry, there do not appear to be bed features that significantly would refract waves toward or away from either of these sites. As such, both of these dewatering sites and the control sites are expected to experience a similar wave climate.

\section{6th Avenue survey}

The bathymetry offshore of the dewatering site at $116^{\text {th }}$ Avenue is shown in Figure 24. Pitting of the lake bed appears to be more extensive at this site, perhaps due to a smaller sediment supply or an increase in the longshore 
gradient. The outer bar is apparent only in the northernmost section of the figure, and the middle bar appears to have advanced toward the shore, rather close to the inner bar. It is difficult to determine how the extensive scarring of the lake bed might affect refraction without applying a numerical model. However, since the dewatering and control site are rather close, it is likely they will experience a similar wave climate.

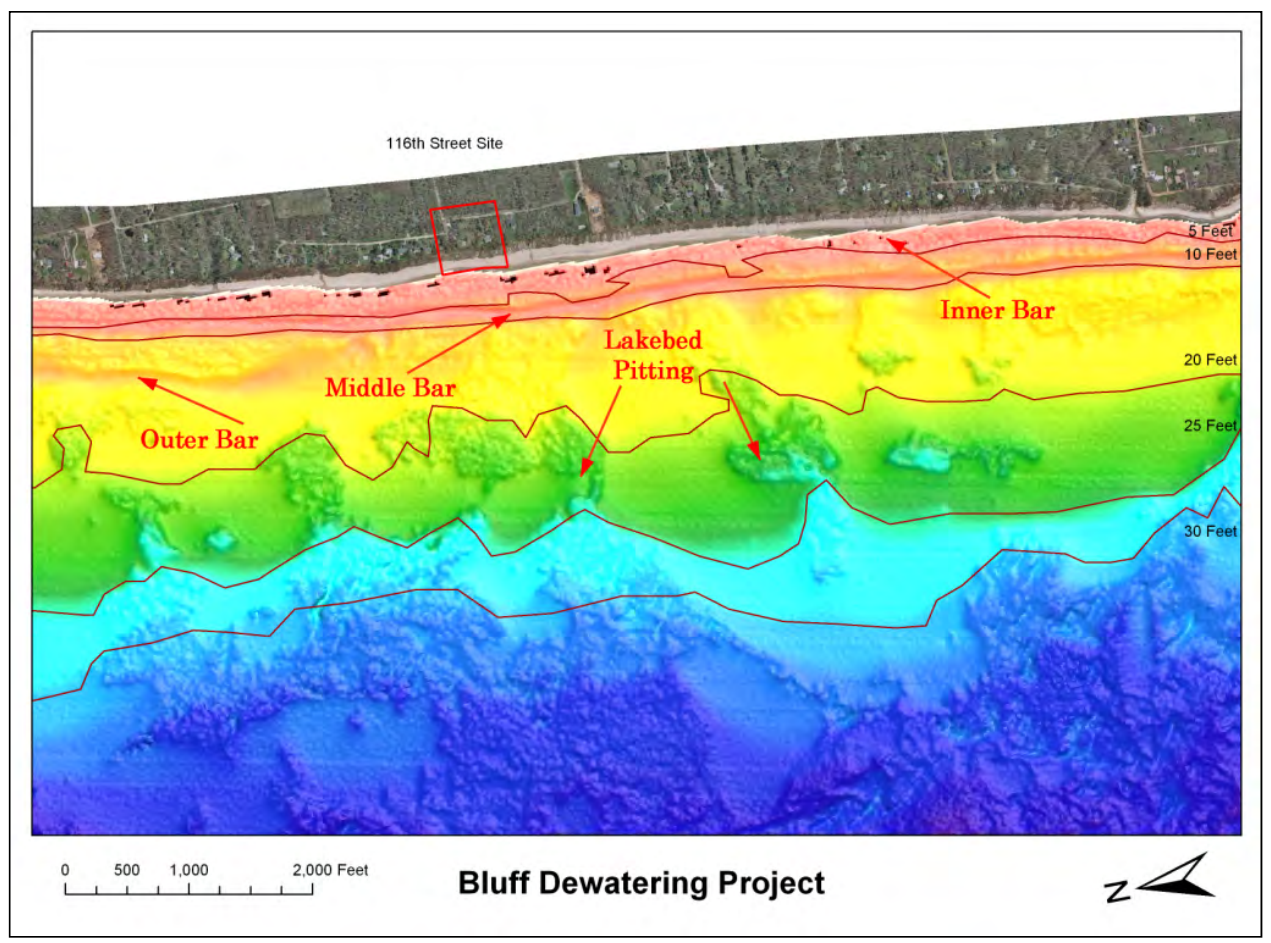

Figure 24 . Bathymetry of $116^{\text {th }}$ (interpreted by James P. Selegean, USACE Detroit District).

\section{Limit equilibrium analyses}

Chase et al. (2001) conducted a series of limit equilibrium analyses using the UTEXAS3 slope stability software package (Edris and Wright 1992) to compare the physical properties of the soils and bluff geometry determined from field and laboratory data against possible failure mechanisms. An example of the analyses is described and illustrated by Figure 25. Failure surfaces interpreted by the Balanced Cross Section Method at MPS Figure 9 were modeled. Slip 1 (the deepest failure surface) was found to be stable (factor of safety $=1.2$ ) when subjected to summer water table levels, yet near failure $(F S=1.0)$ during winter water table levels. The water levels used were mean levels during the winter and summer seasons of the four years (whole years) of the monitored seasons. 


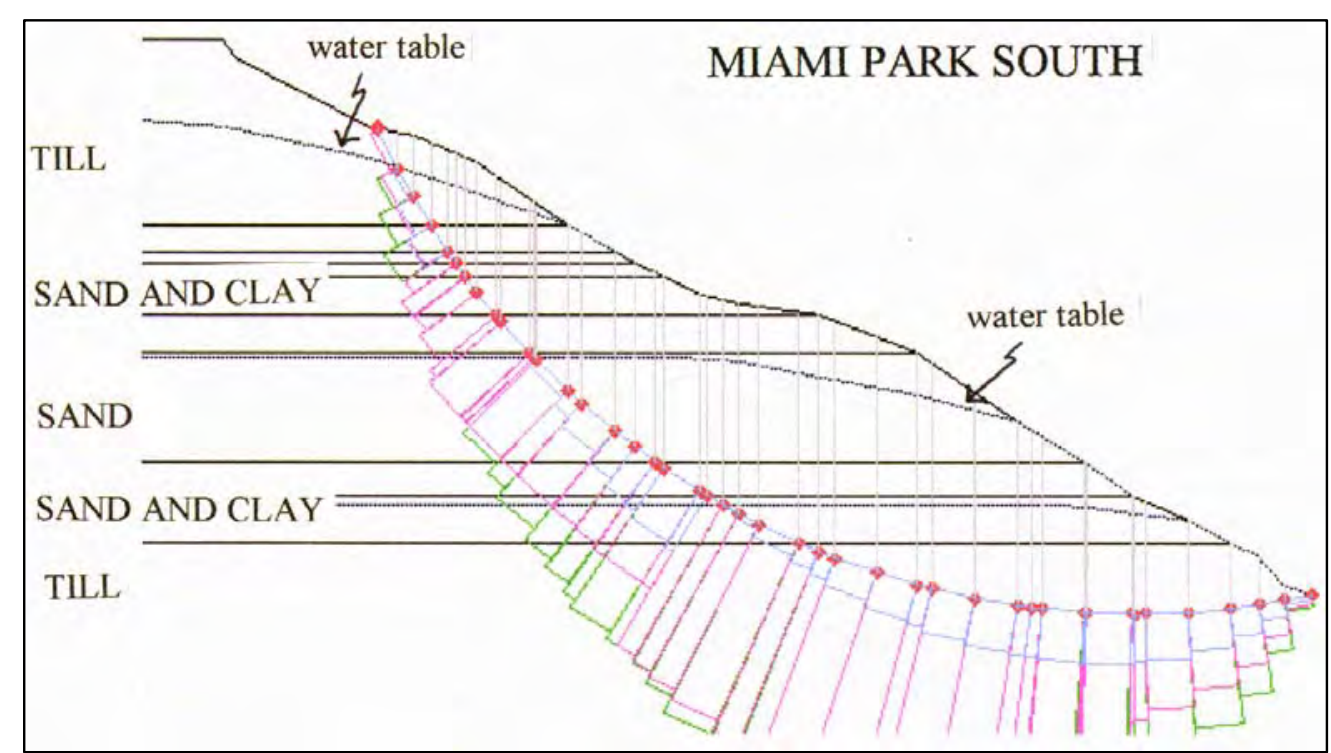

Summer - Fall conditions FS $=1.2$

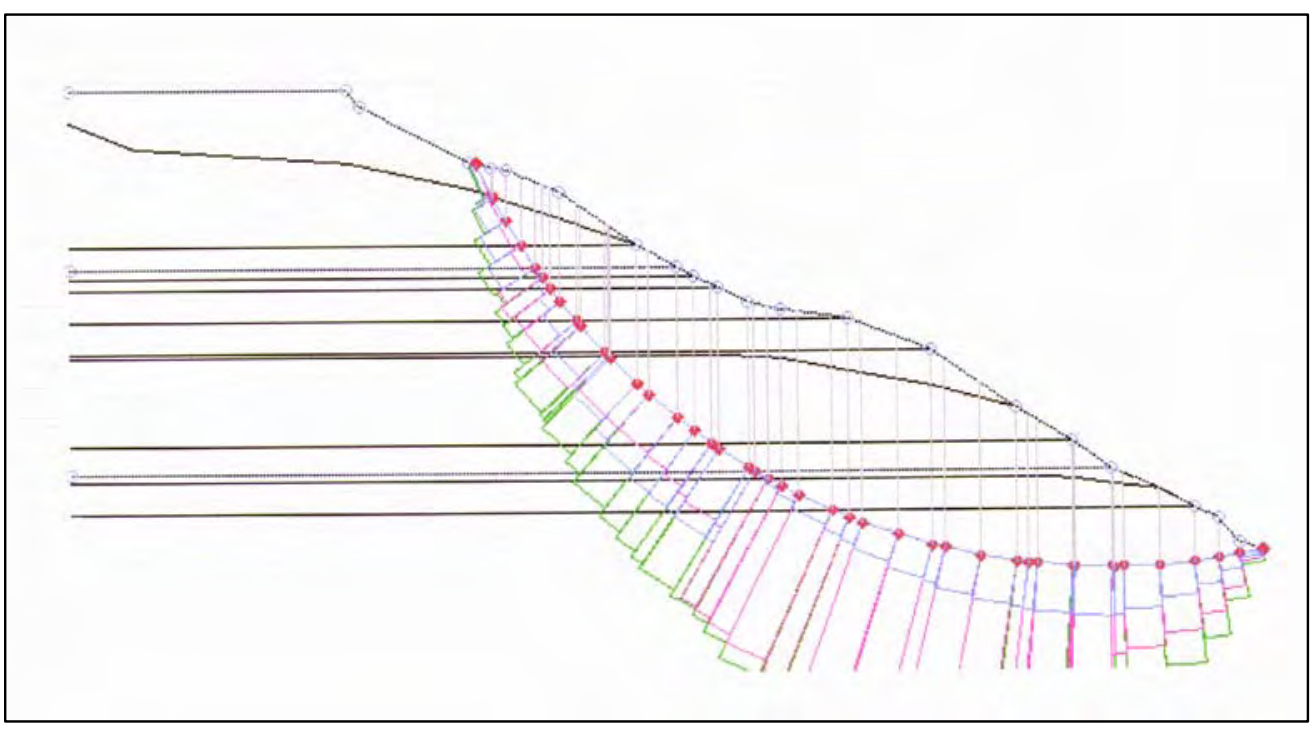

Winter - Spring Conditions, FS $=1.0$

Figure 25. Graphic result of limit equilibrium analysis of Slip Surface 1 in Figure 26. Results of computer simulations (Spencer Method). Space between red dots width of slices. Force vectors at the base of each slice. Total stress $=$ green, effective stress $=$ red, and pore pressure $=$ blue (after Chase et al. 2007b).

Limit equilibrium computer models served as excellent checks of the geometric constructions and suggested mechanisms for slope failures at MPS (Chase et al. 2001b). In general, the limit equilibrium analyses agreed with the yearly field observations of displacement at MPS during periods of elevated groundwater. Also, the computer analyses validate the 
observations that slope instability is not caused by toe erosion itself, but is interdependent on groundwater conditions and stratigraphy, and can be facilitated by toe erosion.

\section{Correlation of pole translations to atmospheric conditions}

Figure 26 is an example plot of the downslope movement of each pole in Survey Line 2 of MPS. The plot shows displacement over a six-year period (1996-2002). Temporal trends in the data are: displacement initiates during the winter months, accelerates in the spring, and slopes are fairly stable during the summer.

When displacement is plotted against ambient temperature, displacement of the poles initiates after prolonged freezing temperatures. In addition, slumping occurs intermittently during freezing conditions and when temperatures rise and the bluffs thaw. When displacement is plotted against precipitation events, trends show increased displacement with high precipitation events. Displacement also is positively correlated to increased piezometric levels, as measured in the upper perched water table in the open standpipes (piezometers installed in 1996). Lastly, displacement is positively correlated to bluff eroding wave events, measured offshore at the NOAA gauging site, Holland, Michigan. These correlations are sound and explicitly illustrated by Figure 27. The top plot in this figure (Survey Pole Translation MPS) contains the same data shown in Figure 26. 


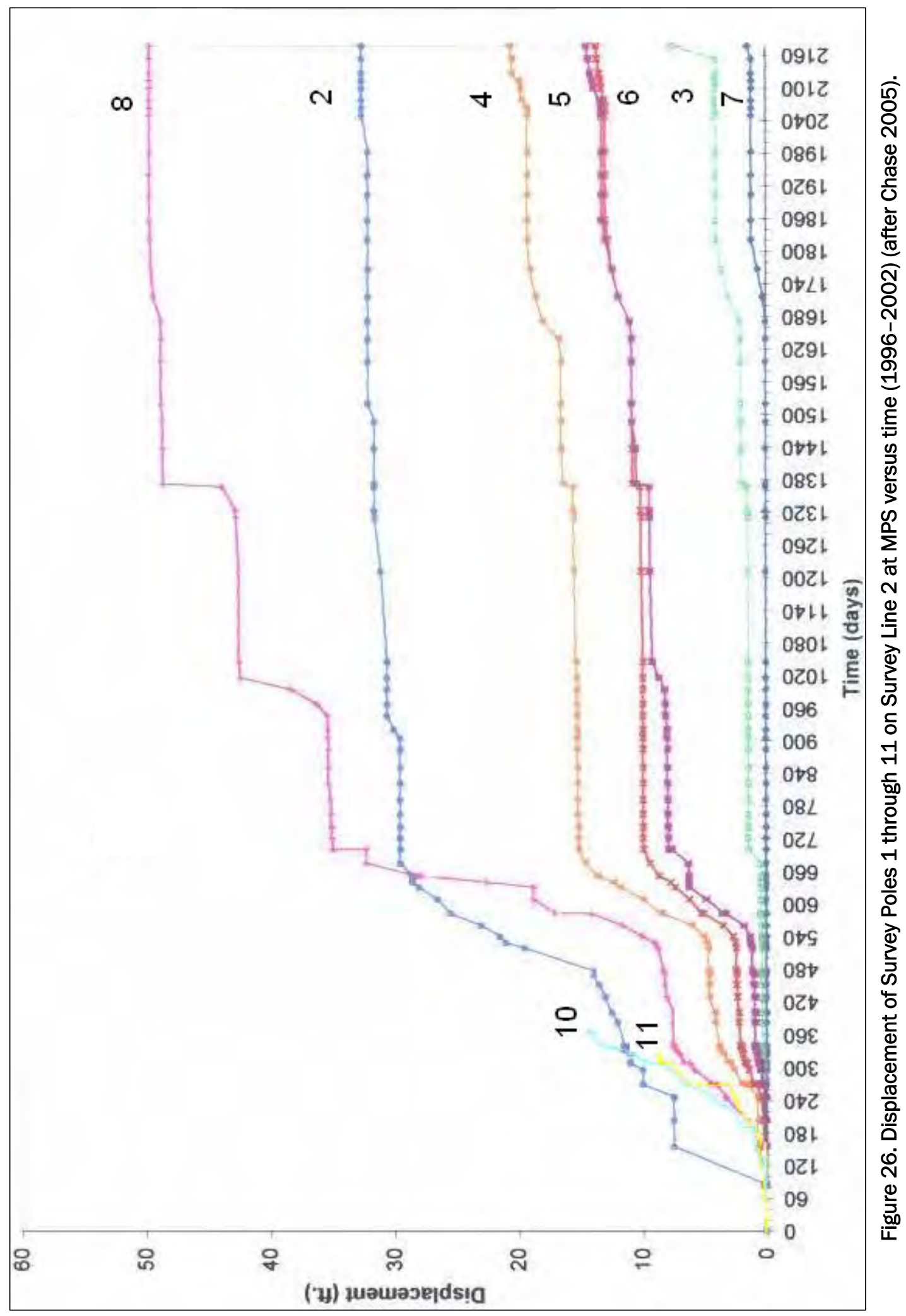




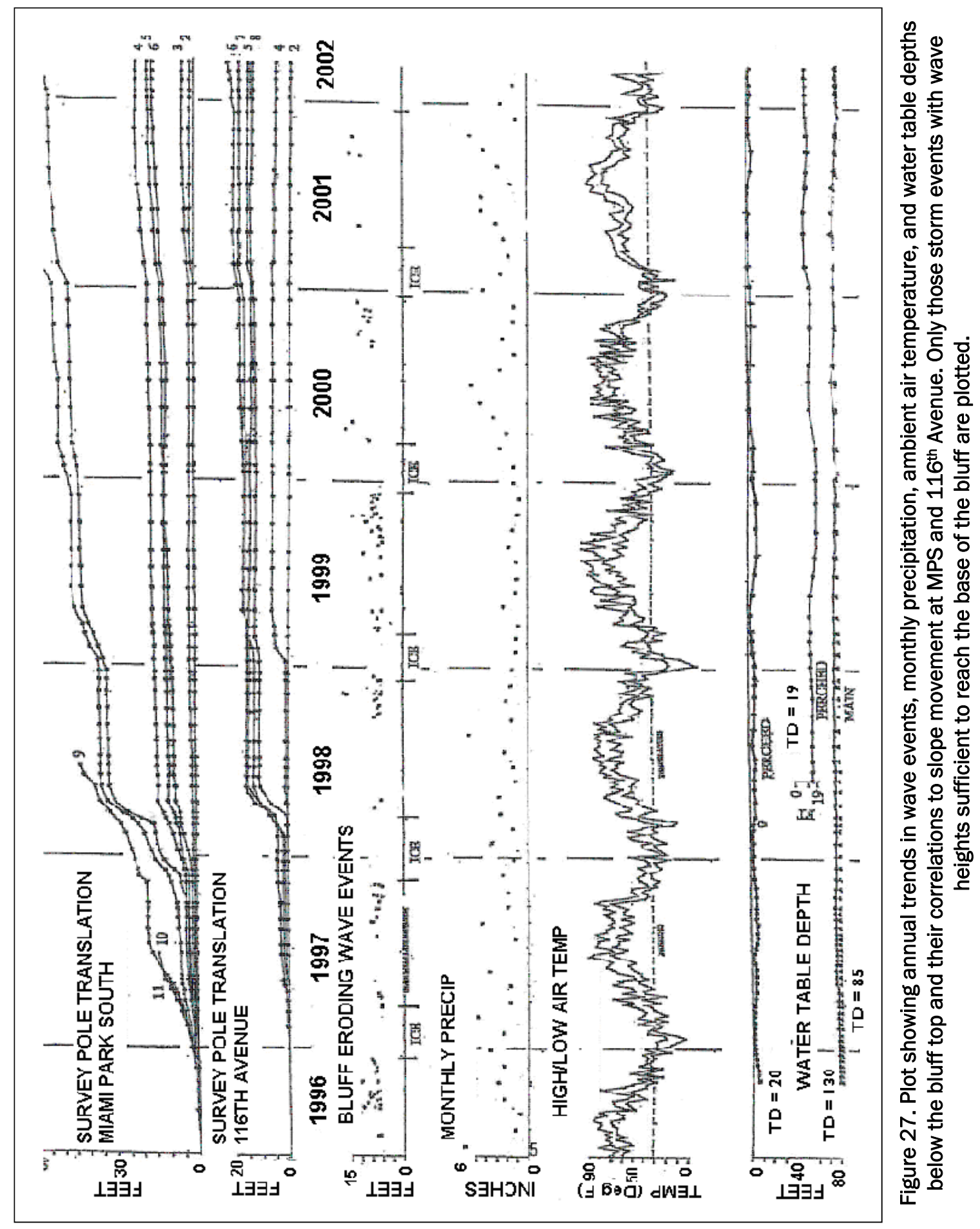




\section{Conclusions: Previous Investigations}

Bluff failures are positively correlated to rises in perched groundwater levels. This relation is based on integrated pole and cable survey (slope movement) data with piezometric data. Ground movement and piezometric levels were recorded from biweekly to triweekly from 1996 to November 2004 at, the MPS, MPN, and 116 th sites.

Rises in perched water tables and, therefore, soil pore pressures are strongly correlated to freezing ambient temperatures. This relation is based on integrated piezometer data with daily air temperature data from 1996 to 2004.

Toe erosion by wave action is one factor in the process of bluff recession; however, it is not the major cause of long-term bluff recession. This conclusion is based on:

- Limit equilibrium analyses of the MPS bluff that show that slumping is possible with an increase in pore pressures similar to those documented in the field, without removal of the bluff toe;

- Recent and persistent low lake-surface elevations since 1999 and the continued slope deformation and bluff erosion observed at the three sites;

- During the study, toe erosion from storm waves that removed material from the toe of the bluff that already had been displaced from above the slope;

- Numerous bluff failures within the study area, none that shows evidence of being caused by toe erosion. Clearly, there are other factors influencing bluff recession besides wave action erosion.

Bluffs composed of mostly sand (greater than 66 percent sand) or mostly of clay (less than 33 percent sand) are more stable and recess at a slower rate than bluffs where alternating layers of sand and clay exist in roughly equal proportions. This conclusion is based on an aerial photographic and fieldmapping study along 10 miles of Lake Michigan shoreline (Montgomery 1998; Chase et al. 1999a). Photos spanned from 1938 to 1996. 
Dewatering of the bluffs might be a viable alternative to the current engineered structures for bluff stabilization. If perched water table levels can be maintained below a critical level during freezing weather (winter) and periods of high precipitation (spring), slope erosion might be slowed or halted. A dewatering scheme that would alternate between winters of pumping and no pumping would demonstrate the effectiveness of dewatering as a bluff stabilization technique. Detailed monitoring of the water extracted and slope deformation is needed to measure effectiveness. Automated instrumentation that records small changes in piezometric levels and bluff movements is needed to statistically define the significance of these variables to the ambient environmental conditions. 


\section{Bluff Dewatering and Stabilization Demonstration}

WMU has monitored surface movements at these sites since 1996 with a simple but ingenious pole-and-cable survey system (Figure 17), described earlier in this report. Slope movements were recorded biweekly to triweekly from 1996 to 2004. Geologic cross sections that illustrate the progressive deformation of bluff strata were developed from these data. Also, the likely locations of water-bearing strata were determined. Deformation measurements along the cable survey system were interfaced with changes in perched water table levels, air temperature, and wave conditions. Empirical data showed that groundwater piezometric highs and lows, as a result of freeze-thaw cycles, were strongly correlated to bluff failure incidence. Limit equilibrium models were constructed to model the field slip failure surfaces, and they validated the empirical correlation of piezometric levels to slope instability.

The current phase of the demonstration project involves dewatering the bluffs' water-bearing strata during winter and spring, when piezometric fluctuations are greatest, to see if stability can be artificially maintained. Dewatering efforts will cease during the summer and fall, when little slope movement normally occurs. Monitoring of bluff conditions will be continuous year-round with the addition of automated instruments and data acquisition units (DAUs). Dewatering will be conducted every other winter/ spring to examine if the effects of dewatering are reversible (i.e., bluff deformation resumes when the bluff is not dewatered). The dewatering demonstration will be considered a success if deformation is significantly less during times of dewatering than times of not dewatering, deformation is significantly less than conventional methods, and is less costly or comparable in cost to conventional methods.

Included in the current demonstration project is development of a groundwater numerical model of the MPS site (Hansen et al. 2007). The purpose of this model is to evaluate the effectiveness of the current pumping scheme and to project the effectiveness of alternative schemes. The accuracy of the model (as in all numerical analyses) depends upon representative geologic and hydraulic conditions, in addition to realistic boundary conditions. 
The geologic/ stratigraphic characteristics of MPS have been well documented and validated by Chase and Kehew. Field hydraulic properties were estimated by limited aquifer testing, conducted in May 2004, and laboratory tests. The development and results of the groundwater model are discussed in this report. The reader is referred to Hansen et al. (2007) for a complete description.

Finally, additional modeling of the MPS bluff (Kuanda 2007) was accomplished using Gaussian quadrature and neural networks. Gaussian quadrature is a numerical integration technique through fixed points that can be used to evaluate length, area, or volume. Using Gaussian quadrature to model the progressive bluff failure at MPS, Kuanda found that the total internal geometrical area of the slump block was preserved during the course of the 11-year progressive deformation. Kuanda also developed four neural network models of MPS to predict slip surface positions based on measured surface displacements and soil types; slope displacement rates from temperature and groundwater level data; groundwater levels based on temperature data; and displacements from precipitation reconds.

The results of the quadrature and neural networks modeling matched the field observations closely. The results are quantitative and in digital form. They can be easily transferred to engineers and planners for use in other applications. The use of these models could be far-reaching and beneficial to the Great Lakes coastal communities. For example, it might allow development of a slope failure warning system that requires minimal monitoring of one or more parameters (e.g., surface movements, climate data, and piezometric surface). Discussion of these models is beyond the scope of this report, and the reader is referred to Kuanda (2007) for a complete explanation.

\section{Dewatering approach}

The dewatering plan included installation of pumping (active) wells and gravity (passive) wells, to enable comparison of effectiveness and costs of dewatering between the two systems. The active wells are vertical borings, cased, with submersible pumps installed at the bottom (Figure 28); the passive wells are horizontal, open-holed, cased, and without pumps. Both well types are cased with Polyvinyl chloride (PVC) pipe, including a slotted section (screen) that spans the proposed dewatered interval. The drains are connected through pipes that discharge into sumps on the beach. These pipes are instrumented with flow meters to measure quantity of water removed. Installation of the wells is summarized in the following section of this report and fully documented in the STS 2005 report. 


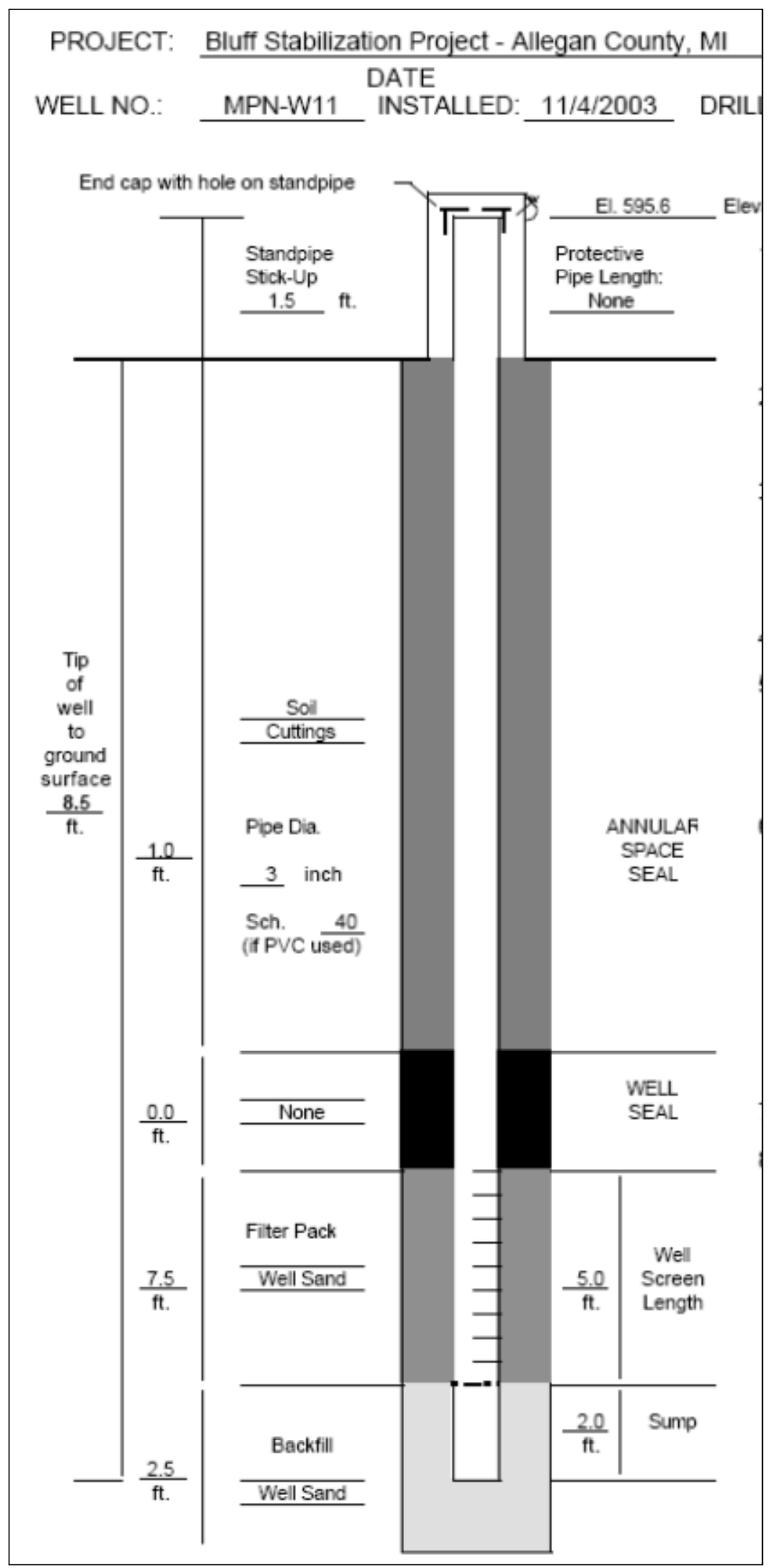

Figure 28. Field well installation diagram (after STS 2005). 
Effectiveness of the dewatering system is evaluated by monitoring slope deformation and perched water table levels along with water extraction rates and volumes. Each demonstration site has a dewatered section and a non-dewatered (control) section. Slope movements at the dewatered section are compared with movements at the control section, which has similar stratigraphy and instrumentation. Elaborate electronic equipment (e.g., inclinometers, piezometers, resistivity probes, thermistors, moisture probes), measure small changes in slope deformation, piezometric levels, soil temperature and moisture, etc., and record the data hourly. The existing pole-and-cable system is functioning as a backup and is surveyed during each site visit.

The automated data collection system is a great improvement over the previous bluff monitoring system for many reasons, including:

- Data are collected hourly versus biweekly or triweekly;

- Data are digital and transferred through dedicated cellular phones to a server offsite;

- Data can be expressed graphically and retrieved $24 \mathrm{hr}$ per day from the server;

- Slip surfaces can be monitored for movement using downhole inclinometers, versus pole-and-cable system (using interpretation of surface expression);

- Soil temperature is being monitored downhole, with depth versus ambient temperatures.

The advanced data system allows examination of near real-time effects of dewatering. In addition, it allows the dynamics of the slope to be monitored in much greater detail, temporally, spatially and within the subsurface. The high frequency of data collection by the automated data acquisition system provides examination of interplay between variables at a high resolution. The field instruments are wired to a data shed equipped with power, control boxes, and cellular phones. Figure 29 shows the data shed on top of the bluff at MPS. Similar sheds are at MPN and $116^{\text {th }}$ Avenue.

\section{Dewatering systems}

The dewatering system for each site was planned according to the available geologic data and knowledge gained from long-term observation and analyses by the researches. The design plan was developed by Chase and Kehew at WMU and constructed by STS with on-site guidance from WMU. 


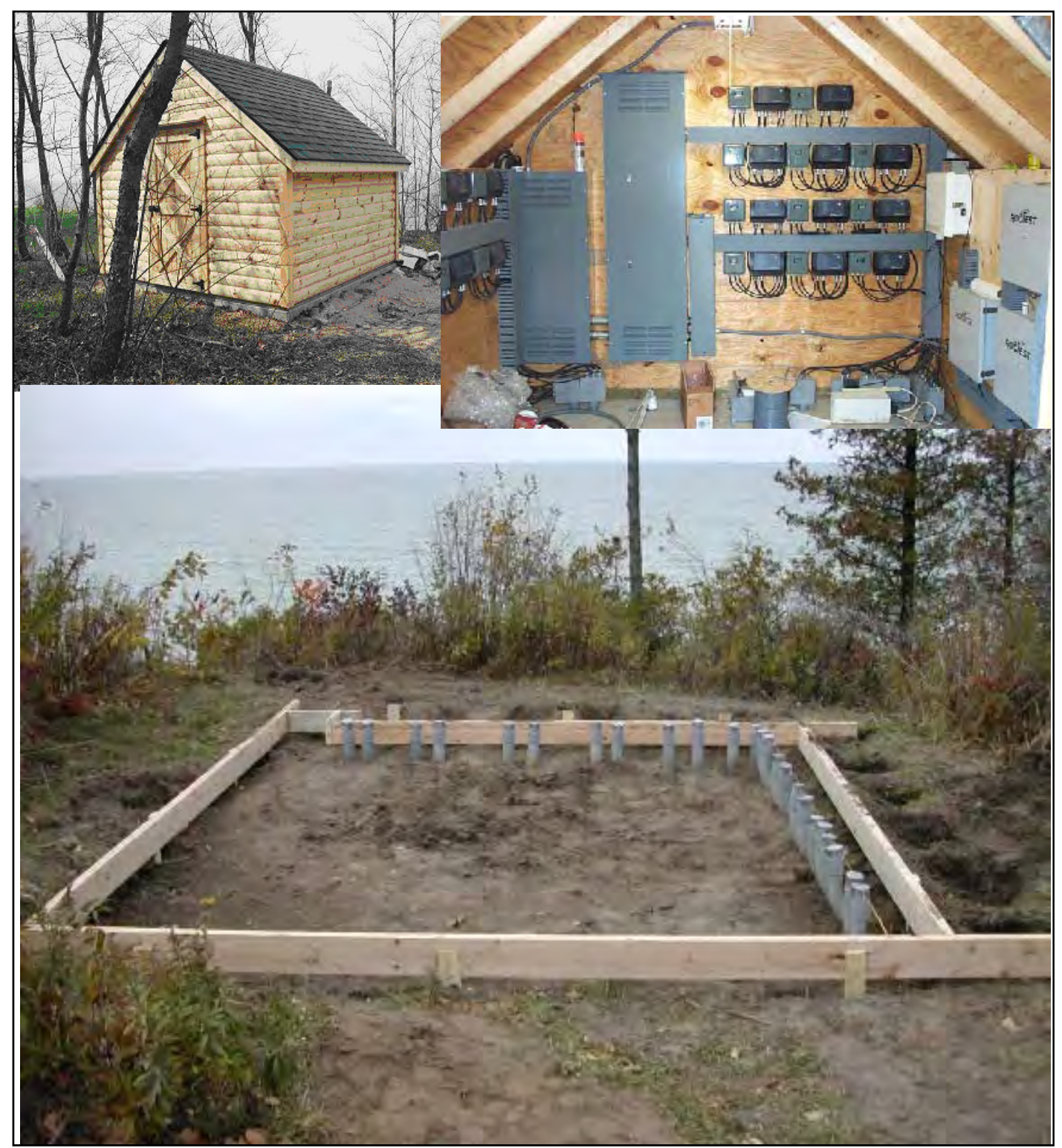

Figure 29. Data-control shed, clockwise from top left, atop each bluff site; pump and instrument control boxes and DAUs inside shed; and construction of shed foundation showing buried conduits for instrumentation wiring.

Dr. J ames P. Selegean and Ronald L. Erickson at the USACE Detroit District oversaw and facilitated the construction.

Each dewatering well was placed within inferred water-bearing layers (usually sand), that also were perched water tables (see Figure 30). The actual orientation, location, and depth of each well were determined in the field during the installation drilling. The dewatering plan (depth and number of wells and other instruments) was based on cross sections interpreted by Chase and Kehew using the Balanced Cross Section Method, 


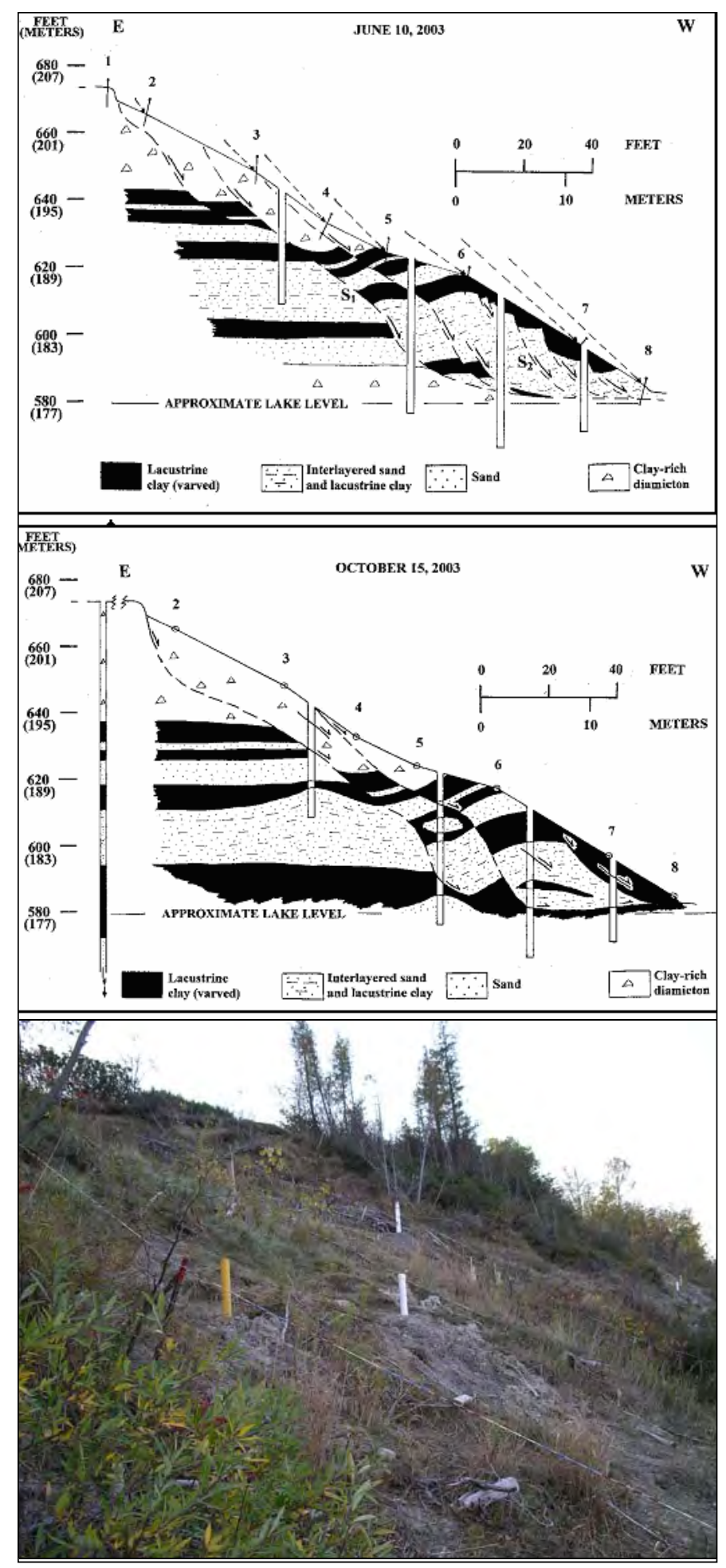

Figure 30. Stratigraphic contacts and slumping, from top, inferred-constructed in June 2003 using the Balanced Cross Section Method (after Chase et al. 2007a) and standpipe boring geology; modification of top cross section (by Ronald B. Chase) after drilling four instrumentation borings; and MPS wells and inclinometers, installed. 
which resulted in cross sections as shown in Figure 30a. The depth of slip surfaces from the inferred cross sections correlated well with the actual slip surfaces found while drilling, also represented in Figure 30b. The depth error for the slip surfaces was 0.75 percent with low deviation. The value of the early cross sections constructed using the Balanced Cross Section Method cannot be overstated. They were instrumental in planning the number and placement of wells and monitoring devices necessary to dewater and monitor effectively.

Active wells included submersible pumps placed at the bottom of the wells. Each pump featured an automatic shutoff that activates when the well water is within $1 \mathrm{ft}$ of the top of the pump. An example of the as-built schematics of the active well borings is shown in Figure 28. Installation details are provided in the STS 2005 report. These pumps can be operated manually or remotely via the cellular phones located in the data shed. Pump controls also are housed in the data shed. The pump settings are from 7,000 to 10,000 revolutions per minute (rpm) and are set to the slowest setting.

An excerpt (STS 2005) describing the well construction and installation at the three sites:

[At Miami Park South and Miami Park North, vertical dewatering wells were installed in predrilled boreholes that were advanced using a Dietrich D-25 rotary drill rig mounted on a six-legged adjustable steel work platform. At 116th and Miami Park North, horizontal dewatering wells were also installed. The horizontal borings at Miami Park North site were completed using a 4-in.-diam hand auger. The horizontal borings at 116th site were completed using a J oy 12 rotary drill rig. The head of the drill rig was rotated approximately $90 \mathrm{deg}$ from vertical to accommodate horizontal drilling.

Typically, the vertical dewatering wells were installed using 4-1/4-in. inside diameter (8-in. outside diameter) hollow stem augers, and the horizontal wells using 4-in.-diam solid stem augers. The wells were constructed of 3-in.-diam threaded Schedule 40 PVC solid risers and 0.10-in. slotted well screen. The bottom of each well was capped.

The vertical well depths ranged from 29 to $44 \mathrm{ft}$ below grade at MPS and from 8.5 to $19 \mathrm{ft}$ at MPN. The screened interval ranged from 5 to 
$15 \mathrm{ft}$, depending on site conditions. Sumps were installed below the majority of the well screens that ranged from 2 to $5 \mathrm{ft}$. The borehole annulus in the screened interval was backfilled with well sand (filter pack). Above the filter pack, the annulus was sealed with bentonite pellets and then native soil cuttings.

The horizontal well depths ranged from 17.5 to $19 \mathrm{ft}$ at MPN and from 19 to $24 \mathrm{ft}$ at 116th. The screened interval was $15 \mathrm{ft}$ at both sites. The borehole annulus was sealed with bentonite pellets, within 2 to $3 \mathrm{ft}$ of the bluff face. The remainder of the borehole annulus remained open. [The annuluses at the screened interval of the horizontal wells were not filter packed.]

Submersible Grundfos pumps were permanently installed inside the vertical dewatering wells, and the pumps wired to the control house at each site. The pumps at each site were connected to a header that flowed and drained by gravity to a sump installed at the toe of the bluff. Heat trace was also installed around the pipes to prevent freezing. The horizontal wells were also connected to a header pipe that drained by gravity to a sump installed at the toe of the bluff.

In addition to the wells installed along the bluff face, a horizontal well was also installed parallel to the bluff crest at MPS and 116th sites. The wells were installed using a horizontal drilling machine. The target depth of the well at MPS was the near surface sand layer with a 1 percent slope to the exit point at the bluff face. The target depth of the well at 116th was the near surface sand layer with a 1 percent slope to the exit point at the bluff face. The approximate alignments of these wells are shown on the plan view figures for the MPS and 116th sites, Figures 10 and 14, respectively.]

\section{Automated instrumentation details}

As part of the earlier investigations by Montgomery (1996), three standpipes were installed approximately $75 \mathrm{ft}$ inland from the crest of the bluffs at MPS and 116th. These acted as open pipe piezometers and provided data for the construction of initial geologic sections shown in Figures 31 and 32. These data were assumed to represent the undisturbed strata, because of their distance from the bluff face. Early correlation of groundwater levels to bluff movement shown in Figure 27 (Chase et al. 2001b) was made using measurements from the shallowest of these standpipes at MPS and $116^{\text {th }}$ 

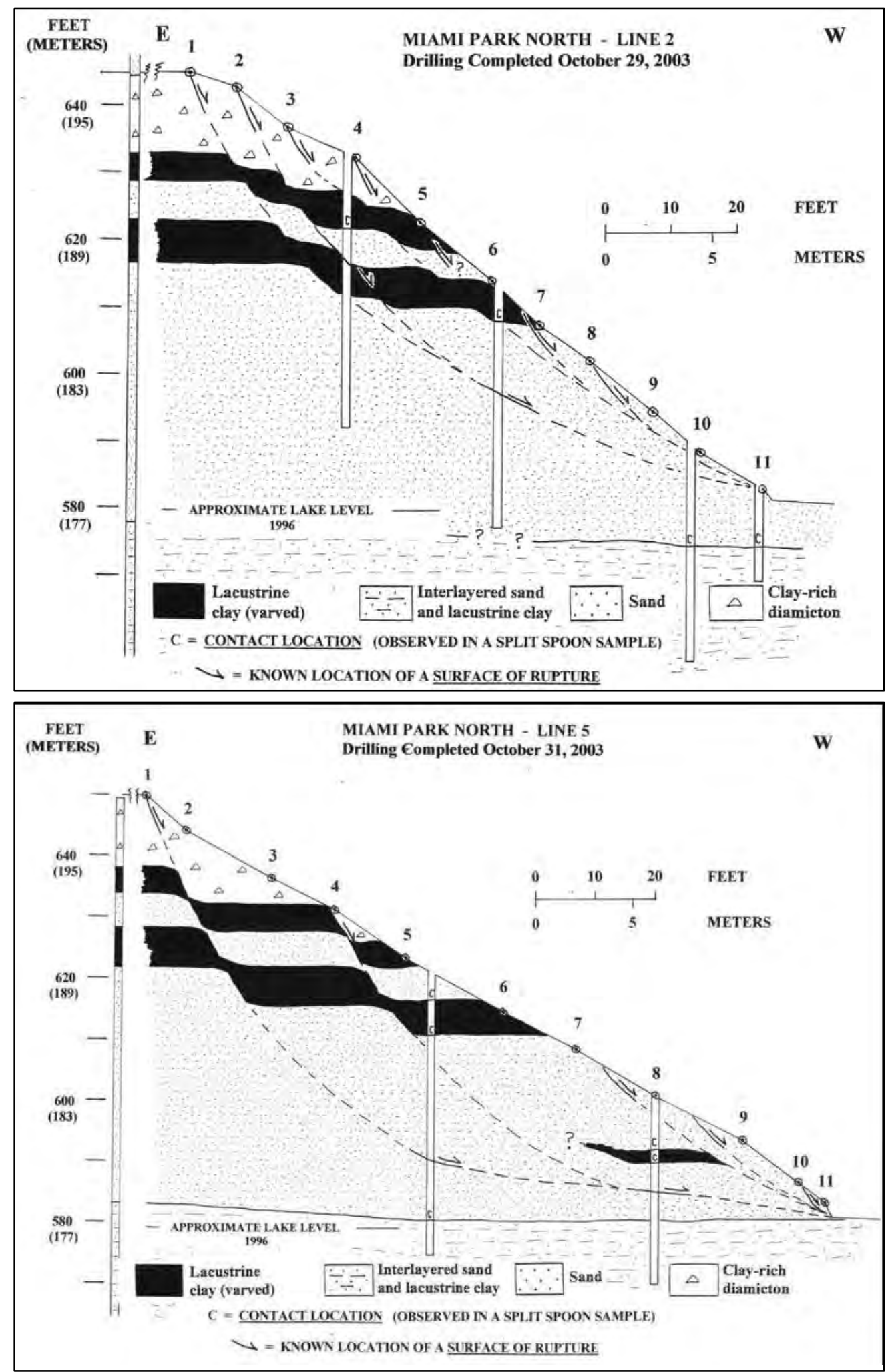

Figure 31. MPN, Line 2, top, and Line 3, bottom, cross sections, modified after drilling instrument and well borings. Note the large percentage of sand in the sections (cross sections interpreted by Ronald B. Chase). Error on bottom figure: Line 3, not 5. 

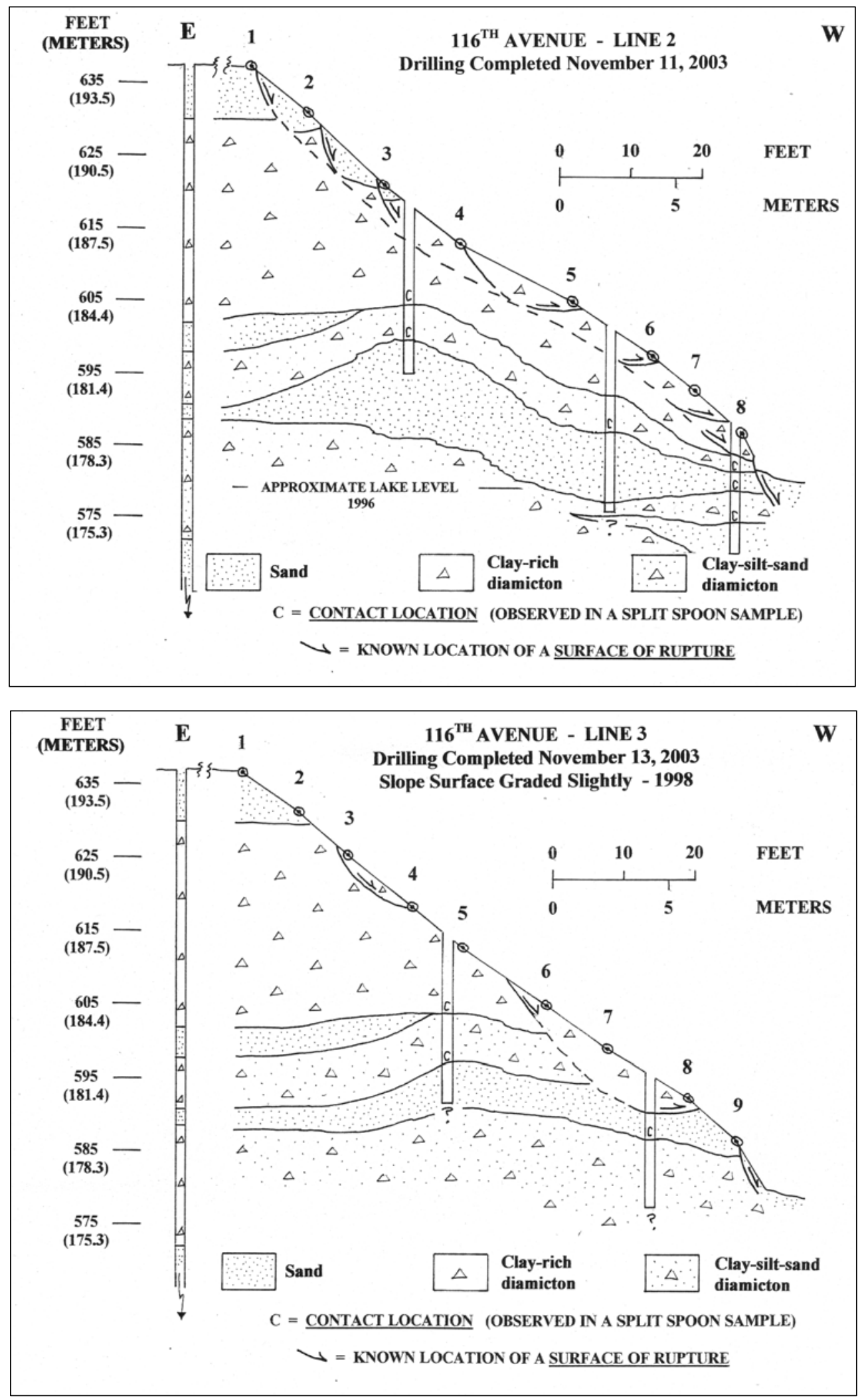

Figure 32. 116th Avenue cross sections for Survey Lines 2 and 3. Sections modified after drilling borings for instrumentation and wells (cross sections drawn by Ronald B. Chase). 


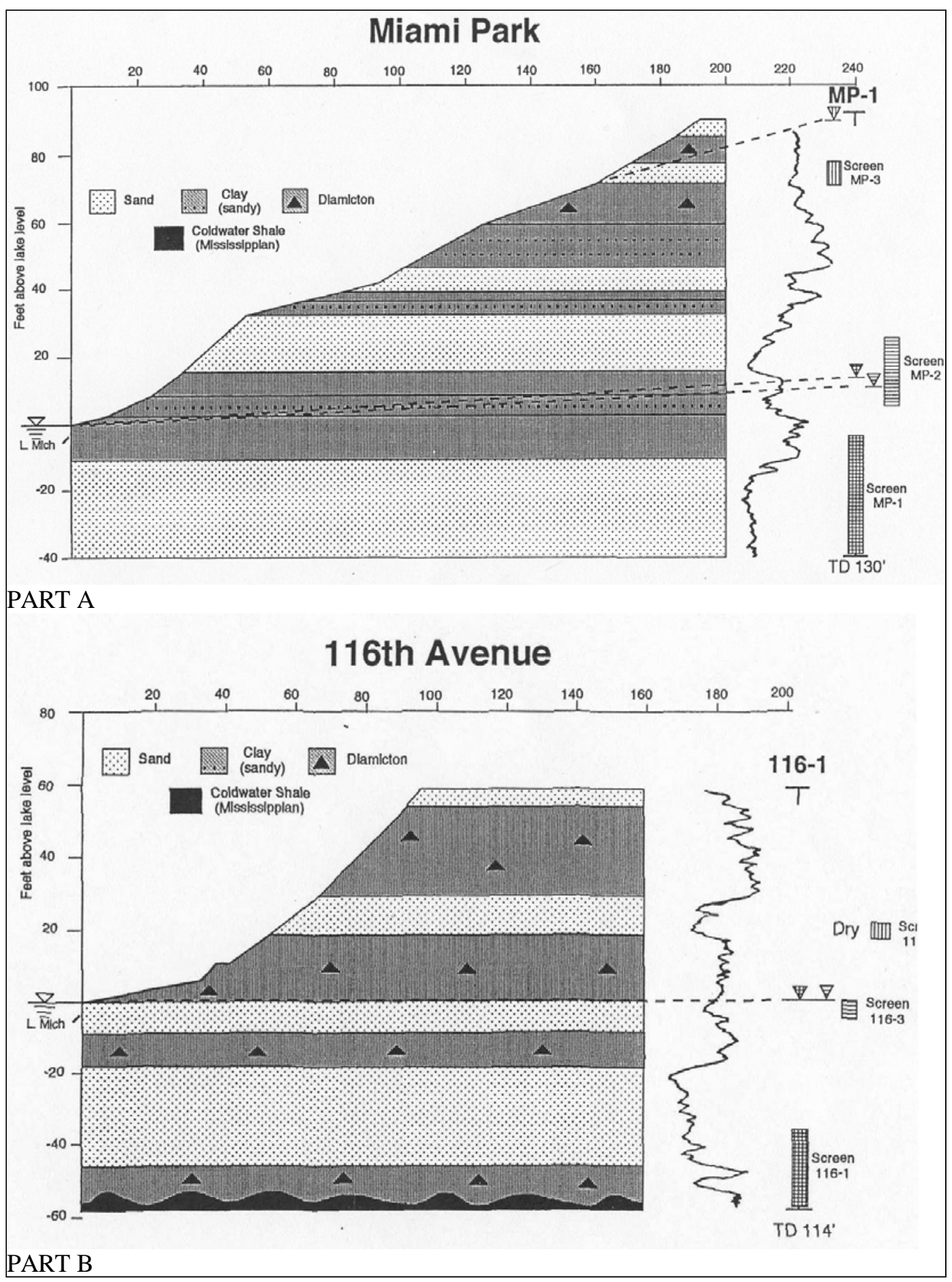

Figure 33. MPS and $116^{\text {th }}$ Avenue initial sections. Depths of standpipe piezometers and gamma ray log shown to the right of section. Water level data is from the Montgomery open standpipes between 1996 and September 2002. The rotosonic VW piezometers (three per well), installed in September 2002, were added to the open standpipe data through December 2004. The bluff-face piezometers, activated in November 2004, and the rotosonic ones have supplied the data since then (cross sections after Montgomery 1998). 
Avenue (personal communication with Chase 2003). Later (2004), modified slug tests were conducted in all three standpipes at MPS to estimate aquifer hydraulic characteristics. Unfortunately, the standpipes at $116^{\text {th }}$ Avenue were buried during construction of the dewatering system.

As part of the dewatering demonstration project, VWPs were installed at each site, MPS, $116^{\text {th }}$ Avenue, and MPN, in borings ALG-02-01, ALG-02-02, and ALG-02-03, respectively. These borings were made at the top of each bluff, and assumed to have intercepted undisturbed (not deformed) strata. The borings were advanced with a rotosonic drill rig that provides a continuous core sample of the boring. Draft geologic boring logs are given in Figure 8. Installation details for these piezometers and a summary of the soil tests conducted are given in Appendix B of this report and in STS (2003). From 2003 to 2004, these piezometers were read manually and later connected to the DAUs.

In late 2004, the second phase of instrumentation was completed. This phase required vertical and horizontal drilling on the slopes to install monitoring instruments and dewatering wells. Drilling on the 25- to 45-deg slope required a crane with a 160 -ft boom to support a drilling platform (Figure 34). The drilling platform had adjustable legs to accommodate the slope, and held the drill and drill operators. Plan views of each site show the as-built location of each instrument and well (Figures 10, 12, and 14 for MPS, MPN, and 116th, respectively).

Monitoring instruments installed included: nested piezometers (pressure transducers) (Figure 35); slope inclinometers (Figure 36); a meteorological station (Figure 37); flow meters; and a thermistor in each piezometer and inclinometer housing. Supplemental instruments provided by the ERDC Cold Regions Research and Engineering Laboratory (CRREL) for monitoring freeze-thaw effects, included moisture and resistivity probes, thermistor strings, and Web cameras. These instruments measure and record small changes in soil water pressure, soil water content, soil and water temperature, air temperature and precipitation, the presence of liquid or frozen pore water, slope movement (i.e., deformation), and quantity of water removed. The flow meters are the only instruments not automated (i.e., they are read manually per site visit). 

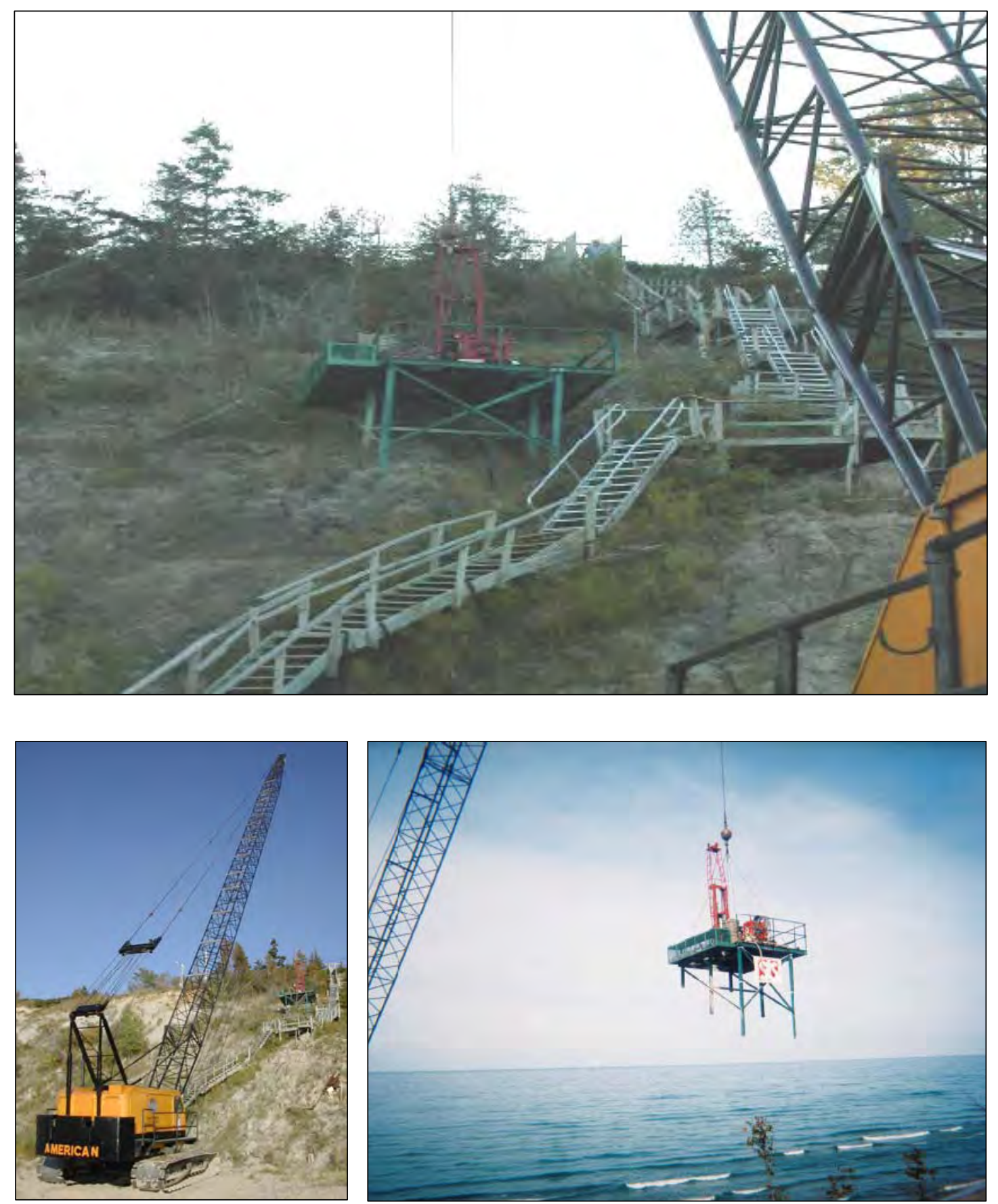

Figure 34. Green drilling platform and red drill at MPS suspended by $100-\mathrm{ft}$ crane. Stairs have been rebuilt three times by property owners because of slope failures (photos after STS 2005). 


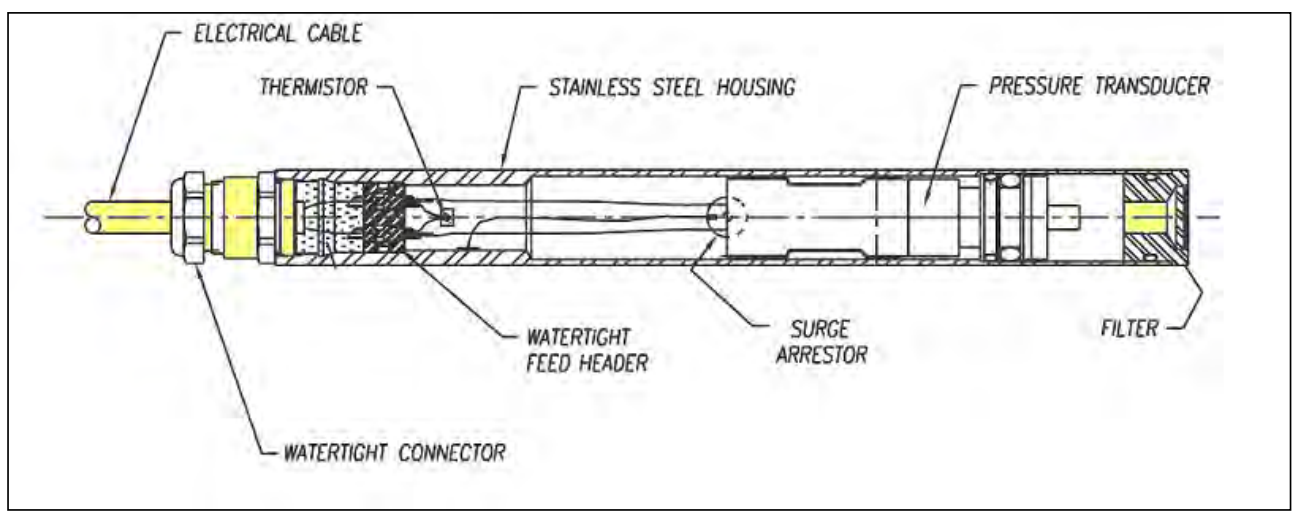

Figure 35. Piezometer schematic, downhole electronic pressure transducer with thermistor (after Roctest 2008).

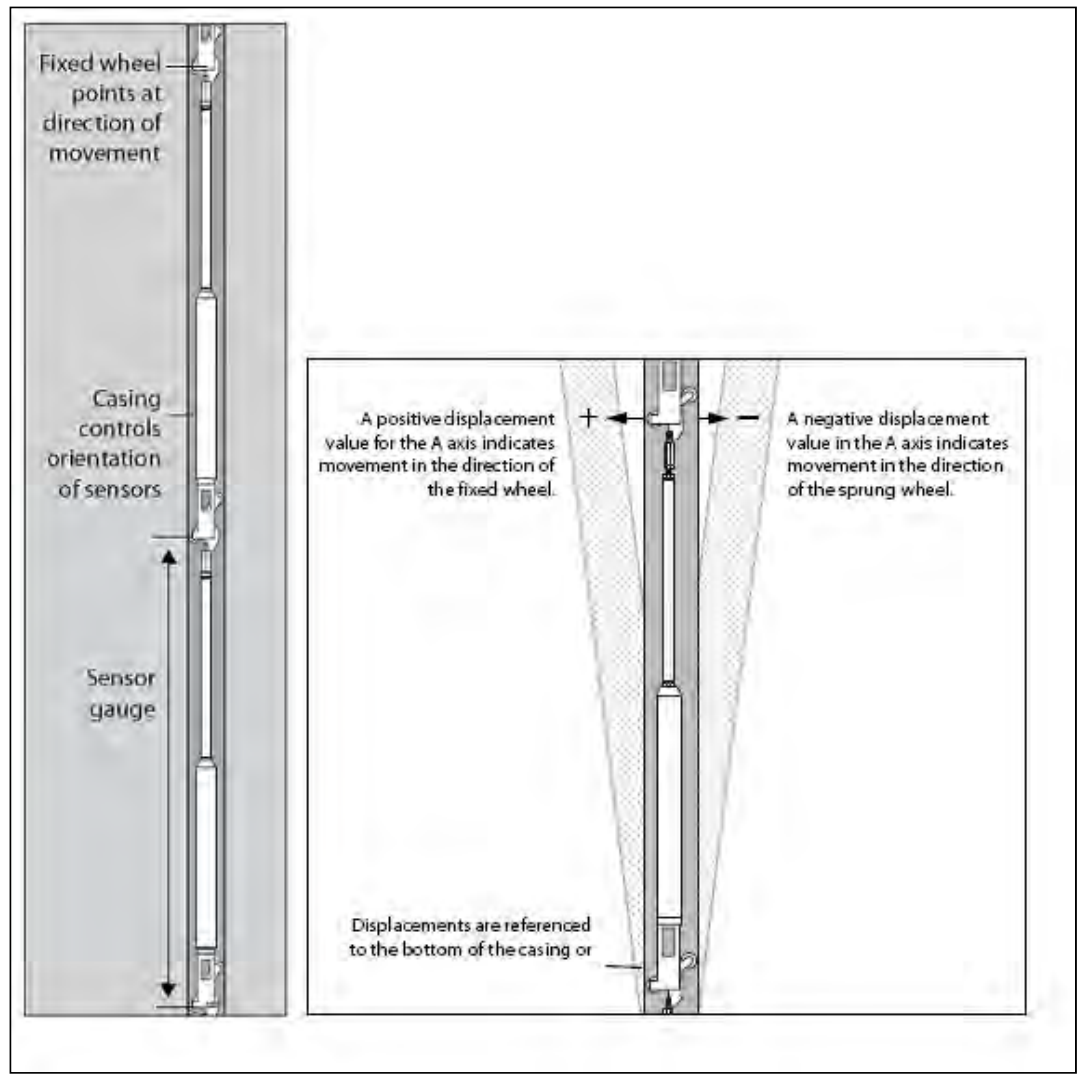

Figure 36. Schematic of downhole inclinometer, instrument for measuring deflection of borehole (deflection is measured in five separate locations within this borehole) (after Slope Indicator Manual 2008). 


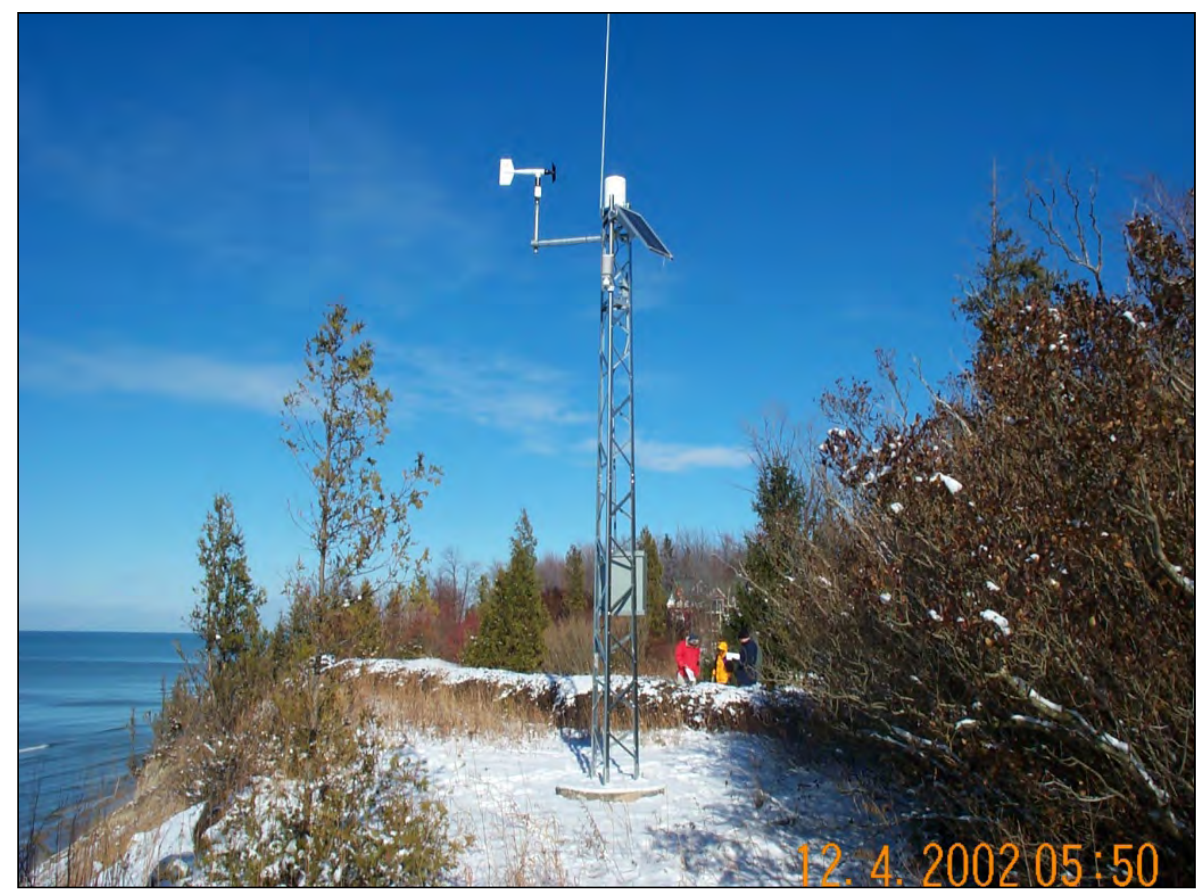

Figure 37. Solar-powered complete weather station at MPS. Identical system at 116th Avenue. Installed by WMU, STS, and USACE, Detroit District.

A summary of the instruments at each site is given in Table 1. In the table, the instruments are separated by their location in the dewatered section or control section. Although the thermistors are listed separately, they are housed within each piezometer and inclinometer and should not be confused with the thermistor strings installed by CRREL. The thermistor strings monitor temperature with respect to depth within a single borehole and are located only at MPS. Instruments installed by STS Consultants are listed in detail in Tables 2, 3, and 4.

The instruments are programmed to read at hourly intervals and automatically send information to a DAU housed atop the bluff. The DAU uploads the data to two computer servers via cellular phone connection in the data shed. One server is maintained by Geocomp Consulting Pty Ltd., Victoria, Australia, and the other is maintained by CRREL, Hanover, New Hampshire. Geocomp processes all the monitoring data related to slope deformation, water table levels and weather, and provides plots for each instrument to the researchers at http://www.geocomp.com/fieldsystems/pdfs/iSite percent20V3 percent20data percent20sheet.pdf. CRREL processes the data related to freeze/ thaw monitoring of the soil, and photos from the Web cameras. This information is available to the researchers at https://Webcam.crrel.usace.army. mil/allegan/. CRREL instruments are discussed in the next section of this report. 
Table 1. Summary of instruments installed at MPS, MPN, and 116th.

\begin{tabular}{|c|c|c|c|}
\hline \multicolumn{4}{|c|}{$\begin{array}{l}\text { Allegan County Bluff Demonstration Sites } \\
\text { (number and placement of monitoring equipment) }\end{array}$} \\
\hline Dewatering section & MPS & MPN & 116th \\
\hline Gravity wells & 1 & 3 & 16 \\
\hline Pumping wells & 17 & 8 & 0 \\
\hline VWPs & 16 & 5 & 4 \\
\hline Thermistors & 51 & 23 & 11 \\
\hline Inclinometers & 35 & 18 & 7 \\
\hline Resistivity probes 7 to $149 \mathrm{~cm}$ & 29 & 0 & 0 \\
\hline $\begin{array}{l}\text { Thermistors at depths of } 0.1 \mathrm{~m}, 0.25 \mathrm{~m} \text {, } \\
0.5 \mathrm{~m}, 0.75 \mathrm{~m}, 1.0 \mathrm{~m}, 1.5 \mathrm{~m} \text {, and } 2.0 \mathrm{~m}\end{array}$ & 7 & 0 & 0 \\
\hline $\begin{array}{l}\text { Stevens Vitel soil moisture probes } 0.5 \text { to } \\
5.4 \mathrm{~m} \text { (each soil moisture probe also } \\
\text { contains a thermistor) }\end{array}$ & 5 & 0 & 0 \\
\hline Control section & MPS & MPN & 116th \\
\hline Piezometers & 2 & 1 & 1 \\
\hline Thermistors & 10 & 2 & 7 \\
\hline Inclinometers & 8 & 1 & 6 \\
\hline Resistivity probes 7 to $149 \mathrm{~cm}$ & 29 & 0 & 0 \\
\hline $\begin{array}{l}\text { Thermistors at depths of } 0.1 \mathrm{~m}, 0.25 \mathrm{~m} \text {, } \\
0.5 \mathrm{~m}, 0.75 \mathrm{~m}, 1.0 \mathrm{~m}, 1.5 \mathrm{~m} \text {, and } 2.0 \mathrm{~m}\end{array}$ & 7 & 0 & 0 \\
\hline $\begin{array}{l}\text { Stevens Vitel soil moisture probes } 0.5 \text { to } \\
5.4 \mathrm{~m} \text { (each soil moisture probe also } \\
\text { contains a thermistor) }\end{array}$ & 5 & 0 & 0 \\
\hline
\end{tabular}


Table 2. Inclinometers and wells Installed at MPS, MPN, and $116^{\text {th }}$ Avenue (after Tables 1, 2, and 3 , STS 2005). (continued on next two pages)

\begin{tabular}{|c|c|c|c|c|}
\hline \multicolumn{5}{|c|}{$\begin{array}{l}\text { INSTRUMENT ELEVATION AND LOCATION SUMMARY } \\
\text { MIAMI PARK SOUTH }\end{array}$} \\
\hline \multicolumn{5}{|c|}{ STS PROJECT NUMBER 7-74257A } \\
\hline \multicolumn{5}{|c|}{ INCLINOMETERS } \\
\hline WELL NAME & NORTH & EAST & $\begin{array}{l}\text { N. TOP/PVC } \\
\text { ELEVATION }\end{array}$ & $\begin{array}{l}\text { GROUND } \\
\text { ELEVATION }\end{array}$ \\
\hline MPS-11 & 357327.755 & 12614194.842 & 639.33 & 637.33 \\
\hline MPS-12 & 357340.499 & 12614161.954 & 625.20 & 623.01 \\
\hline MPS-13 & 357349.149 & 12614136.648 & 610.96 & 608.76 \\
\hline MPS-14 & 357355.960 & 12614115,454 & 596,79 & 594.39 \\
\hline MPS-15 & 357221.923 & 12614163.082 & 642.26 & 621.60 \\
\hline MPS-16 & 357375.960 & 12614176.930 & 626.63 & 624.00 \\
\hline MPS -17 & 357275.945 & 12614170.522 & 634.00 & 631.72 \\
\hline MPS-18 & 357288.183 & 12614128.060 & 615.90 & 613.28 \\
\hline MPS-19 & 357213.329 & 12614108.378 & 611.02 & 609.66 \\
\hline MPS-110 & 357132.523 & 12614129,398 & 633.92 & 631.18 \\
\hline MPS-111 & 357142.112 & 12614078.301 & 607.27 & 604.12 \\
\hline MPS-112 & 357417.118 & 12614178.870 & 622.74 & 639.95 \\
\hline
\end{tabular}

VERTICAL WELLS

\begin{tabular}{|c|c|c|c|c|}
\hline WELL NAME & NORTH & EAST & $\begin{array}{c}\text { N. TOP/PVC } \\
\text { ELEVATION }\end{array}$ & $\begin{array}{c}\text { GROUND } \\
\text { ELEVATION }\end{array}$ \\
\hline MPS-W1 & 357394.708 & 12614216.474 & 649.11 & 646.53 \\
\hline MPS-W2 & 357409.727 & 12614184.213 & 627.39 & 625.86 \\
\hline MPS-W3 & 357415.611 & 12614163.340 & 610.29 & 608.96 \\
\hline MPS-W4 & 357226.607 & 12614198.285 & 639.74 & 637.74 \\
\hline MPS-W5 & 357362.625 & 12614172.365 & 626.07 & 624.09 \\
\hline MPS-W6 & 357367.467 & 12614148.777 & 614.42 & 610.80 \\
\hline MPS-W7 & 357316.626 & 12614191.142 & 639.22 & 637.26 \\
\hline MPS-W8 & 357331.069 & 12614157.034 & 624.39 & 612.31 \\
\hline MPS-W9 & 357335.145 & 12614137.174 & 613.66 & 638.75 \\
\hline MPS-W10 & 357267.108 & 12614182.662 & 639.90 & 624.03 \\
\hline MPS-W11 & 357283.020 & 12614149.514 & 626.14 & 613.60 \\
\hline MPS-W12 & 357289.771 & 12614129.345 & 614.30 & 634.98 \\
\hline MPS-W13 & 357210.365 & 12614148.003 & 637.88 & 606,95 \\
\hline MPS-W14 & 357220.738 & 12614164.314 & 641.58 & 630.19 \\
\hline MPS-W15 & 357244.891 & 12614152.794 & 632.34 & 609.00 \\
\hline MPS-W16 & 357253.134 & 12614114.526 & 610.62 & 638.78 \\
\hline MPS-W17 & 357368.251 & 12614105.973 & 608.33 & \\
\hline
\end{tabular}

Notes: HORIZONTAL COORDINATES - MICHIGAN SOUTH ZONE 2113 NAD 83/1994

VERTICAL DATUM - IGLD 1985

SURVEY DATA COLLECTED JUNE 22-24, 2004

BENCHMARK - ACOE BRASS DISK ON CONTROL BUILDING SLAB - ELEVATION $669.79 \mathrm{ft}$. 


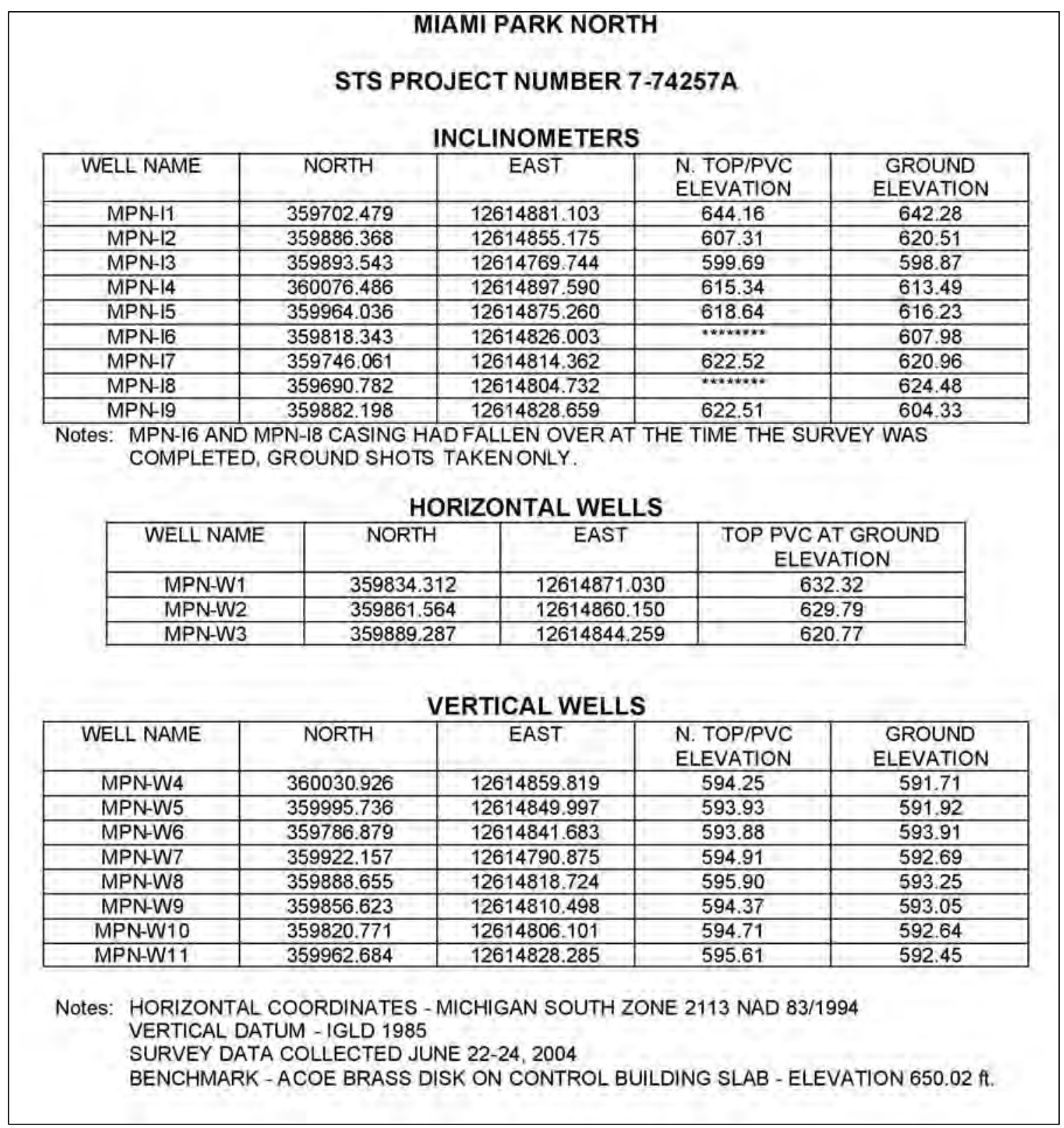




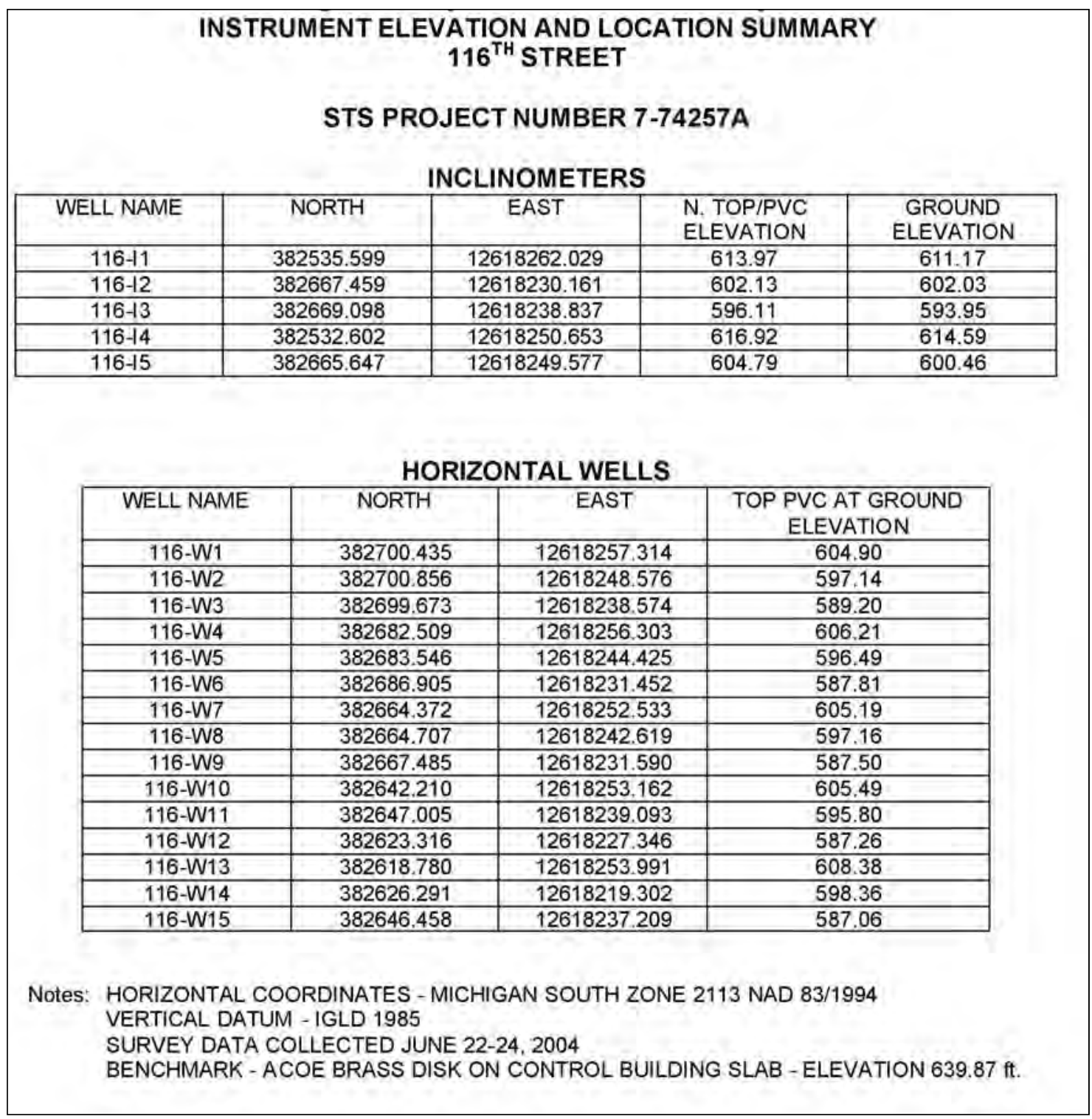


Table 3. Inclinometer details for MPS, MPN, and $116^{\text {th }}$ (after Tables 4, 5, and 6, STS 2005). (continued on next page)

\begin{tabular}{|c|c|c|c|c|c|c|c|c|c|c|c|}
\hline \multirow[b]{3}{*}{$\begin{array}{c}\text { Boring } \\
\text { Hole }\end{array}$} & \multicolumn{9}{|c|}{$\begin{array}{l}\text { Allegan County - Bluff Stabilization Project } \\
\text { INCLINOMETER DETAILS - MIAMI PARK SOUTH } \\
\text { STS PROJECT NUMBER 7-74257A }\end{array}$} & & \\
\hline & \multirow{2}{*}{$\begin{array}{l}\text { Boring } \\
\text { Depth } \\
\text { (ft) }\end{array}$} & \multirow{2}{*}{$\begin{array}{c}\text { Approx. } \\
\text { Casing } \\
\text { Depth (ft) }\end{array}$} & \multirow[b]{2}{*}{$\begin{array}{c}\text { Number of } \\
\text { Inclinometers }\end{array}$} & \multirow[b]{2}{*}{$\begin{array}{l}\text { Inclinometer } \\
\text { Depth (ft) }\end{array}$} & \multirow[b]{2}{*}{$\begin{array}{l}\text { Serial } \\
\text { Number }\end{array}$} & \multicolumn{6}{|c|}{ Inclinometer Initial Readings } \\
\hline & & & & & & Date & $\begin{array}{c}\text { Panel } \\
\text { No. }\end{array}$ & Channel & $\begin{array}{l}X \text {-Axis } \\
\text { (volts) }\end{array}$ & $\begin{array}{l}\text { Y-Axis } \\
\text { (volts) }\end{array}$ & $\begin{array}{l}\text { Temp. } \\
\text { (volts) }\end{array}$ \\
\hline \multirow[t]{3}{*}{ MPS-11 } & 36.5 & 34 & 3 & 10 & 1799 & $5 / 6 / 04$ & 1 & 5 & 0.316 & 0.485 & 0.094 \\
\hline & & & & 20 & 1795 & $5 / 6 / 04$ & 1 & 4 & -0.62 & -0.528 & 0.101 \\
\hline & & & & 30 & 1856 & $5 / 6 / 04$ & 1 & 6 & -0.912 & 0.436 & 0.1 \\
\hline \multirow[t]{5}{*}{ MPS-12 } & 46.5 & 45 & 5 & 10 & 1855 & $5 / 6 / 04$ & 1 & 14 & -0.912 & 0.435 & 0.099 \\
\hline & & & & 20 & 1840 & $5 / 6 / 04$ & 1 & 1 & $-0,116$ & 0.018 & 0.09 \\
\hline & & & & 25 & 1851 & $5 / 6 / 04$ & 1 & 3 & -0.313 & -0.614 & 0.079 \\
\hline & & & & 30 & 1844 & $5 / 6 / 04$ & 1 & 2 & -0.506 & 0.064 & 0.111 \\
\hline & & & & 40 & 1802 & $5 / 6 / 04$ & 1 & 7 & -0.102 & -0.493 & 0.08 \\
\hline \multirow[t]{5}{*}{ MPS-13 } & 45.5 & 44 & 5 & 5 & 1837 & $5 \longdiv { 7 1 0 4 }$ & 4 & 15 & -0.252 & 0.898 & 0.095 \\
\hline & & & & 15 & 1808 & $5 / 7 / 04$ & 4 & 13 & 1.579 & 0.397 & 0.09 \\
\hline & & & & 20 & 1823 & $5 / 704$ & 4 & 14 & 0.527 & -0.184 & 0.072 \\
\hline & & & & 25 & 1835 & $5 / 7 / 04$ & 4 & 16 & 0.578 & -0.402 & 0.104 \\
\hline & & & & 35 & 1826 & $5 / 7 / 04$ & 4 & 1 & 0.527 & -0.184 & 0.071 \\
\hline \multirow[t]{3}{*}{ MPS-14 } & 25.5 & 25 & 3 & 5 & 1834 & $5 / 6 / 04$ & 1 & 9 & 0.575 & -0.232 & 0.079 \\
\hline & & & & 10 & 1813 & $5 / 6 / 04$ & 1 & 12 & -0.048 & +0.282 & 0.091 \\
\hline & & & & 20 & 1843 & $5 / 6 / 04$ & 1 & 11 & 0.541 & 0.739 & 0.097 \\
\hline \multirow[t]{3}{*}{ MPS-15 } & 34 & 32 & 3 & 10 & 1825 & $5 / 6 / 04$ & 1 & 13 & 0.249 & -0.087 & 0.086 \\
\hline & & & & 20 & 1814 & $5 / 6 / 04$ & 1 & 8 & 0.735 & -0.379 & 0.085 \\
\hline & & & & 30 & 1804 & $5 / 6 / 04$ & 1 & 10 & -0.109 & -1.036 & 0.103 \\
\hline MPS-16 & 41.5 & 36 & 0 & NA & $\mathrm{NA}$ & & & iclinometer & not insta & & \\
\hline \multirow[t]{5}{*}{ MPS-17 } & 53 & 52 & 5 & 10 & 1794 & $5 / 7 / 04$ & 4 & 6 & 0.351 & 0.384 & 0.096 \\
\hline & & & & 20 & 1841 & $5 / 704$ & 4. & 2 & -0.006 & 0.045 & 0.109 \\
\hline & & & & 30 & 1853 & $5 / 7 / 04$ & 4 & 3 & 0.612 & 0.126 & 0.122 \\
\hline & & & & 40 & 1838 & $5 / 7 / 04$ & 4 & 4 & 0.612 & 0.126 & 0.122 \\
\hline & & & & 50 & 1842 & $577 / 04$ & 4 & 4 & 0.6 & 0,125 & 0.094 \\
\hline \multirow[t]{5}{*}{ MPS-18 } & 51.5 & 47 & 5 & 5 & 1839 & $5 / 6 / 04$ & 3 & 12 & -0.17 & 0.409 & 0.079 \\
\hline & & & & 15 & 1798 & $5 / 6 / 04$ & 3 & 10 & 0.572 & 0252 & 0.114 \\
\hline & & & & 25 & 1830 & $5 / 6 / 04$ & 3 & 13 & 4.24 & 0.506 & 0.095 \\
\hline & & & & 35 & 1810 & $5 / 6 / 04$ & 3 & 11 & -0.473 & 0.206 & 0.102 \\
\hline & & & & 45 & 1854 & $5 / 6 / 04$ & 3 & 9 & -0.152 & 0.936 & 0.099 \\
\hline \multirow[t]{4}{*}{ MPS-19 } & 42,5 & 42 & 4 & 10 & 1817 & $5 / 7 / 04$ & 2 & 2 & 0.786 & 0.096 & 0.08 \\
\hline & & & & 20 & 1850 & $5 / 7 / 04$ & 2 & 6 & 0.447 & -0.499 & 0,144 \\
\hline & & & & 30 & 1829 & $5 \pi / 04$ & 2 & 7 & 0.253 & 0.059 & 0.12 \\
\hline & & & & 40 & 1832 & $5 / 7 / 04$ & 2 & 5 & 0.116 & 0.04 & 0.093 \\
\hline \multirow[t]{4}{*}{ MPS-110 } & 40 & 39 & 4 & 5 & 1833 & $5 / 6 / 04$ & 3 & 8 & -0.121 & 0.437 & 0.104 \\
\hline & & & & 15 & 1807 & $5 / 6 / 04$ & 3 & 6 & 0.467 & .0 .335 & 0.095 \\
\hline & & & & 25 & 1849 & $5 / 6 / 04$ & 3 & 5 & 0.28 & 0.102 & 0.099 \\
\hline & & & & 35 & 1852 & $5 / 6 / 04$ & 3. & 7 & 0.926 & -1.211 & 0.108 \\
\hline \multirow[t]{4}{*}{ MPS-111 } & 39 & 37 & 4 & 5 & 1845 & $5 / 6 / 04$ & 3 & 1 & 1.19 & -0.081 & 0.073 \\
\hline & & & & 15 & 1809 & $5 / 6 / 04$ & 3 & 2 & 0.707 & -0.053 & 0.091 \\
\hline & & & & 25 & 1806 & $5 / 6 / 04$ & 3 & 4 & 0.358 & -0.248 & 0.104 \\
\hline & & & & 35 & 1821 & $5 / 6 / 04$ & 3 & 3 & 0.58 & -0.3 & 0.092 \\
\hline \multirow[t]{3}{*}{ MPS-112 } & 36.5 & 35 & 3 & 10 & 1790 & $5 / 7 / 04$ & 2 & 3 & 0.852 & 1.017 & 0.099 \\
\hline & & & & 20 & 1796 & $57 / 04$ & 2 & 4 & -0.323 & 0.306 & 0.113 \\
\hline & & & & 30 & 1803 & $57 / 104$ & 2 & 1 & 0.202 & 0.805 & 0.131 \\
\hline TOTALS & $\overline{492}$ & 468 & $\overline{44}$ & & & & & & & & \\
\hline
\end{tabular}




\begin{tabular}{|c|c|c|c|c|c|c|c|c|c|c|c|}
\hline \multicolumn{12}{|c|}{$\begin{array}{l}\text { INCLINOMETER DETAILS - MIAMI PARK NORTH } \\
\text { STS PROJECT NUMBER 7-74257A }\end{array}$} \\
\hline \multirow[b]{2}{*}{$\begin{array}{c}\text { Boring } \\
\text { No. }\end{array}$} & \multirow{2}{*}{$\begin{array}{l}\text { Boring } \\
\text { Depth } \\
\text { (ft) }\end{array}$} & \multirow{2}{*}{$\begin{array}{c}\text { Approx. } \\
\text { Casing } \\
\text { Depth (ft) }\end{array}$} & \multirow[b]{2}{*}{$\begin{array}{c}\text { Number of } \\
\text { Inclinometers }\end{array}$} & \multirow[b]{2}{*}{$\begin{array}{c}\text { Inclinometer } \\
\text { Depth (ft) }\end{array}$} & \multirow[b]{2}{*}{$\begin{array}{c}\text { Serial } \\
\text { Number }\end{array}$} & \multicolumn{6}{|c|}{ Inclinometer Initial Readings ${ }^{\text {(1) }}$} \\
\hline & & & & & & Date & $\begin{array}{c}\text { Panel } \\
\text { No. }\end{array}$ & Channel & $\begin{array}{l}X \text {-Axis } \\
\text { (volts) }\end{array}$ & $\begin{array}{l}Y \text {-Axis } \\
\text { (volts) }\end{array}$ & $\begin{array}{l}\text { Temp. } \\
\text { (volts) }\end{array}$ \\
\hline \multirow[t]{3}{*}{ MPN-11 } & 41.5 & \begin{tabular}{|l|}
38.5 \\
\end{tabular} & 3 & 5 & 2466 & - & 1 & - & - & - & - \\
\hline & & & & 15 & 2464 & - & 1 & - & - & - & - \\
\hline & & & & 25 & 2472 & - & 1 & - & - & - & - \\
\hline \multirow{4}{*}{ MPN-12 } & 36.5 & 34 & 4 & 5 & 2465 & - & 1 & - & - & - & - \\
\hline & & & & 15 & 2473 & - & 1 & - & - & - & - \\
\hline & & & & 25 & 2458 & - & 1 & - & - & - & - \\
\hline & & & & 30 & 2456 & - & 1 & - & - & - & - \\
\hline \multirow[t]{3}{*}{ MPN-13 } & 32.5 & 30 & 3 & 5 & 2468 & - & 1 & - & - & - & - \\
\hline & & & 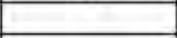 & 15 & 2476 & - & 1 & - & - & - & - \\
\hline & & & & 20 & 2475 & - & 1 & - & - & $=$ & - \\
\hline \multirow[t]{3}{*}{ MPN-14 } & 40 & 39 & 3 & 10 & 2460 & - & 1 & - & - & - & - \\
\hline & & & & 20 & 2470 & $=$ & 1 & $=$ & - & - & - \\
\hline & & & & 30 & 2471 & - & 1 & - & - & - & $=$ \\
\hline MPN-15 & 36.5 & 34 & 0 & NA & NA & \multicolumn{6}{|c|}{ Inclinometers not installed } \\
\hline \multirow[t]{2}{*}{ MPN-16 } & 40 & 35 & 2 & 5 & 2362 & e & 1 & $-\quad$ & - & - & $=$ \\
\hline & & & & 15 & 2455 & - & 1 & - & - & - & - \\
\hline \multirow[t]{3}{*}{ MPN-17 } & 41.5 & 39 & 3 & 10 & 2452 & - & 1 & - & - & - & - \\
\hline & & & & 20 & 2462 & - & 1 & - & - & - & - \\
\hline & & & & 30 & 2463 & - & 1 & $=$ & - & $z$ & - \\
\hline MPN-18 & 46.5 & 44 & 0 & NA & NA & \multicolumn{6}{|c|}{ inclinometers not installed } \\
\hline MPN-19 & 31.5 & 29 & 1 & 5 & 2449 & - & 1 & - & - & - & - \\
\hline TOTALS & 346.5 & 322.5 & 19 & & & & & & & & \\
\hline
\end{tabular}

\begin{tabular}{|c|c|c|c|c|c|c|c|c|c|c|c|}
\hline \multirow[b]{3}{*}{$\begin{array}{l}\text { Boring } \\
\text { No. }\end{array}$} & \multicolumn{10}{|c|}{$\begin{array}{l}\text { Aliegan County - Bluff Stabilization Project } \\
\text { INCLINOMETER DETAILS - } 116 \text { th AVENUE } \\
\text { STS PROJECT NUMBER } 7-74257 \text { A }\end{array}$} & \\
\hline & \multirow[b]{2}{*}{$\begin{array}{c}\text { Boring } \\
\text { Depth } \\
\text { (ft) }\end{array}$} & \multirow{2}{*}{$\begin{array}{c}\text { Approx. } \\
\text { Casing } \\
\text { Depth (ft) }\end{array}$} & \multirow[b]{2}{*}{$\begin{array}{c}\text { Number of } \\
\text { Inclinometers }\end{array}$} & \multirow[b]{2}{*}{$\begin{array}{c}\text { Inclinometer } \\
\text { Depth (ft) }\end{array}$} & \multirow[b]{2}{*}{$\begin{array}{c}\text { Serial } \\
\text { Number }\end{array}$} & \multicolumn{6}{|c|}{ Inclinometer Initial Readings (1) } \\
\hline & & & & & & Date & $\begin{array}{c}\text { Panel } \\
\text { No. }\end{array}$ & Channel & $\begin{array}{l}X \text {-Axis } \\
\text { (volts) }\end{array}$ & $\begin{array}{l}\text { Y-Axis } \\
\text { (volts) }\end{array}$ & $\begin{array}{l}\text { Temp. } \\
\text { (volts) }\end{array}$ \\
\hline $116-11$ & 25 & 23 & 0 & NA & NA & \multicolumn{6}{|c|}{ Inclinometers not installed } \\
\hline \multirow[t]{4}{*}{$116-12$} & 31.5 & 25 & 4 & 5 & 1848 & - & - & - & - & - & - \\
\hline & & & & 10 & 1800 & - & - & - & - & - & - \\
\hline & & & & 15 & 1836 & - & - & - & - & - & - \\
\hline & & & & 20 & 1846 & - & - & - & $y$ & $=$ & - \\
\hline \multirow[t]{3}{*}{$116-13$} & 21.5 & 17 & 3 & 4 & 2457 & - & 2 & - & - & - & 2 \\
\hline & & & & 9 & 1725 & - & - & - & - & - & - \\
\hline & & & & 14 & 1828 & - & - & - & - & - & - \\
\hline \multirow[t]{3}{*}{$116-14$} & 26.5 & 23 & 3 & 5 & 2477 & - & - & - & - & - & - \\
\hline & & & & 10 & 2459 & - & - & - & - & - & - \\
\hline & & & & 20 & 2453 & - & - & - & - & $=$ & $=$ \\
\hline \multirow[t]{3}{*}{$116-15$} & 21.5 & 18.5 & 3 & 5 & 2451 & - & - & - & - & - & - \\
\hline & & & & 10 & 2461 & - & - & - & - & - & - \\
\hline & & & & 15 & 1847 & - & - & - & - & - & - \\
\hline TOTALS & 126 & 106.5 & 13 & & & & & & & & \\
\hline
\end{tabular}


Table 4. Piezometer details for MPS, MPN, and $116^{\text {th }}$ Avenue (after STS 2005).

\begin{tabular}{|c|c|c|c|c|c|c|c|c|c|c|c|}
\hline \multicolumn{12}{|c|}{$\begin{array}{l}\text { Allegan County - Bluff Stabilization Project } \\
\text { PIEZOMETER DETAILS - MIAMI PARK SOUTH }\end{array}$} \\
\hline \multicolumn{12}{|c|}{ STS PROJECT NUMBER 7-74257A } \\
\hline \multirow[b]{2}{*}{$\begin{array}{l}\text { Borehole } \\
\text { Number }\end{array}$} & \multirow[b]{2}{*}{$\begin{array}{c}\text { Piezometer } \\
\text { Serial Number }\end{array}$} & \multirow[b]{2}{*}{$\begin{array}{c}\text { Date } \\
\text { Installed }\end{array}$} & \multirow[b]{2}{*}{$\begin{array}{c}\text { Depth } \\
\text { Below } \\
\text { Surface }(\mathrm{ft})\end{array}$} & \multicolumn{3}{|c|}{ Initial VW Piezometer Readings } & \multicolumn{5}{|c|}{ VW Piezometer Readings } \\
\hline & & & & Date & $\begin{array}{l}\text { Frequency } \\
(\mathrm{Hz})\end{array}$ & $\begin{array}{l}\text { Temperature } \\
\text { ("C) }\end{array}$ & Panel No. & Channel & Date & $\begin{array}{l}\text { Frequency } \\
(\mathrm{Hz})\end{array}$ & $\begin{array}{c}\text { Temperature } \\
\left({ }^{\circ} \mathrm{C}\right)\end{array}$ \\
\hline MPS-P1 & 1000011163 & $9 / 17 / 03$ & 23.5 & $9 / 18 / 03$ & 1678.3 & 110 & 5 & 1 & $10 / 2 / 03$ & 16790 & 11.2 \\
\hline MPS.P2 & 1000011160 & $9 / 16 / 03$ & 36 & $9 / 16 / 03$ & 1838.7 & 10.4 & 5 & 7 & $10 / 2 / 03$ & 18357 & 109 \\
\hline MPS.P3 & 1000011166 & $9 / 15 / 03$ & 25 & NR & $\mathrm{NR}$ & NR & 5 & 16 & $10 / 2 / 03$ & 2018.2 & 11.2 \\
\hline MPS-P4 & $100 \mathrm{D011167}$ & $9 / 12 / 03$ & 18 & $9 / 12 / 03$ & 16356 & 126 & 5 & 14 & $10 / 2 / 03$ & 16334 & 125 \\
\hline MPS-P5 & 1000011168 & $9 / 23 / 03$ & 16.75 & $9 / 24 / 03$ & 2245.7 & 12.5 & 5 & 15 & $10 / 2 / 03$ & 2241.6 & 127 \\
\hline MPS.P6 & 1000011154 & $8 / 18 / 03$ & 20 & $9 / 19 / 03$ & 1739.1 & 10.9 & 6 & 1 & $10 / 2 / 03$ & 1739.6 & 11.1 \\
\hline MPS-P7 & 1000011157 & $9 / 25 / 03$ & 19 & $9 / 26 / 03$ & 1997.6 & 114 & 5 & 11 & $10 / 2 / 03$ & 1993.7 & 115 \\
\hline MPS-P8 & $100 \mathrm{D} 011156$ & $9 / 24 / 09$ & 10.5 & $9 / 25 / 03$ & 1731.0 & 15.6 & 5 & 10 & $10 / 2 / 03$ & 1727.1 & 15.5 \\
\hline MPS-P8 & 1000011161 & $9 / 24 / 03$ & 27 & $9 / 25 / 03$ & 1793.3 & 102 & 5 & 8 & $10 / 2 / 03$ & 1789.2 & 10.1 \\
\hline MPS-P9 & 1000011165 & $9 / 26 / 03$ & B & $9 / 29 / 03$ & 16825 & 174 & 5 & 3 & $10 / 2 / 03$ & 1677.5 & 16.7 \\
\hline MPS-P9 & 100D011155 & $9 / 26 / 03$ & 22.5 & $9 / 29 / 03$ & 20618 & 112 & 5 & 2 & $10 / 2103$ & 2059.6 & 11.3 \\
\hline MPS-P10 & 1000011162 & $9 / 26 / 03$ & 21 & $9 / 29 / 03$ & 1838.8 & 115 & 5 & 13 & $10 / 2 / 03$ & 18357 & 11.5 \\
\hline MPS.P11 & 1000011168 & $9 / 30 / 03$ & 16 & $10 / 1 / 03$ & 19451 & 12.3 & 5 & 8 & $10 / 2 / 03$ & 19438 & 124 \\
\hline MPS-P12 & 1000011159 & $10 / 15 / 03$ & 28.5 & $10 / 16 / 03$ & 20357 & 10.6 & 5 & 12 & NR & NR & NR \\
\hline ALG-02-01 & 74723 & $9 / 4 / 02$ & 45 & $9 / 5 / 02$ & 3147.0 & 13.4 & 5. & 5 & $10 / 3 / 02$ & 31470 & 11.2 \\
\hline ALG-02-01 & 74724 & $9 / 4 / 02$ & 75 & $9 / 5 / 02$ & 3098.3 & 140 & 5 & 4 & $10 / 3 / 02$ & 3097.9 & 10.5 \\
\hline ALG-02-01 & 74720 & $9 / 4 / 02$ & 105 & $9 / 5 / 02$ & 2993.1 & 11.8 & 6 & 2 & $10 / 3 / 02$ & 2994.1 & 10.4 \\
\hline \multicolumn{12}{|c|}{$\begin{array}{l}\text { Allegan County - Bluff Stabilization Project } \\
\text { PIEZOMETER DETAILS - MIAMI PARK NORTH }\end{array}$} \\
\hline \multicolumn{12}{|c|}{ STS PROJECT NUMBER 7-74257A } \\
\hline & & & & \multicolumn{3}{|c|}{ Initial VW Piezometer Readings } & \multicolumn{5}{|c|}{ Vw Piezometer Readings "II } \\
\hline $\begin{array}{l}\text { Borehole } \\
\text { Number }\end{array}$ & $\begin{array}{c}\text { Piezometer } \\
\text { Serial Number }\end{array}$ & $\begin{array}{c}\text { Date } \\
\text { Installed }\end{array}$ & $\begin{array}{c}\text { Depth } \\
\text { Below } \\
\text { Surface }(\mathrm{ft})\end{array}$ & Date & $\begin{array}{l}\text { Frequency } \\
(\mathrm{Hz})\end{array}$ & $\begin{array}{l}\text { Temperature } \\
\text { ("C) }\end{array}$ & Panel No. & Channel & Date & $\begin{array}{l}\text { Frequency } \\
(\mathrm{Hz})\end{array}$ & $\begin{array}{c}\text { Temperature } \\
\left({ }^{\circ} \mathrm{C}\right)\end{array}$ \\
\hline MPN-P1 & 100003919 & $10 / 31 / 03$ & 13.5 & $11 / 3 / 03$ & 2019.8 & 130 & - & $-\quad$ & - & -2 & $\ln ^{2}$ \\
\hline MPN-P2 & 100003921 & $10 / 31 / 03$ & 14.5 & $11 / 3 / 03$ & 1851.7 & 112 & - & - & + & - & - \\
\hline MPS.P9 & 100003920 & $10 / 31 / 03$ & 19.2 & $11 / 3 / 03$ & 2081.6 & 110 & $=$ & $=$ & . & $=$ & - \\
\hline ALG.02.03 & 74719 & $9 / 6 / 02$ & 23 & $9 / 6 / 02$ & 3082.1 & 137 & - & - & 2 & $=$ & - \\
\hline ALG.02.03 & 74718 & $9 / 6 / 02$ & 45 & $9 / 6 / 02$ & 30971 & 157 & - & - & . & $=$ & 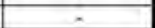 \\
\hline ALG.02-03 & 74721 & $9 / 6 / 02$ & 75 & $9 / 6 / 02$ & 3083.4 & 126 & - & - & - & - & - \\
\hline Note: & \multicolumn{11}{|c|}{ "it' Piezometer readings not obtained by $9 T \mathrm{TS}$} \\
\hline \multicolumn{12}{|c|}{$\begin{array}{l}\text { Allegan County - Bluff Stabilization Project } \\
\text { PIEZOMETER DETAILS - 116th AVENUE }\end{array}$} \\
\hline \multicolumn{12}{|c|}{ STS PROJECT NUMBER 7-74257A } \\
\hline & & & & \multicolumn{3}{|c|}{ Initial VW Piezometer Readings } & \multicolumn{5}{|c|}{ VW Piezometer Readings "II } \\
\hline $\begin{array}{l}\text { Borehole } \\
\text { Number }\end{array}$ & $\begin{array}{c}\text { Piezometer } \\
\text { Serial Number }\end{array}$ & Date Installed & $\begin{array}{c}\text { Depth Below } \\
\text { Surface (fi) }\end{array}$ & Date & $\begin{array}{l}\text { Frequency } \\
(\mathrm{Hz})\end{array}$ & $\begin{array}{c}\text { Temperature } \\
\left({ }^{\circ} \mathrm{C}\right)\end{array}$ & Panel No. & Channel & Date & $\begin{array}{l}\text { Frequency } \\
(\mathrm{Hz})\end{array}$ & Temperature $\left({ }^{\circ} \mathrm{C}\right)$ \\
\hline $116-P 2$ & 1000011164 & $11 / 12003$ & 25 & $11 / 13 / 03$ & 2007.7 & 11.7 & 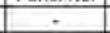 & - & - & -1 & - \\
\hline $116-P 4$ & 100003918 & $11 / 1203$ & 13 & $11 / 13 / 03$ & 2026.6 & 130 & - & - & - & $=$ & - \\
\hline ALG-0302 & 74716 & $9 / 4 / 02$ & 5 & $9 / 6 / 02$ & 3129.7 & 16.6 & $=$ & 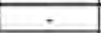 & $10 / 3 / 02$ & 31312 & 14 \\
\hline ALG-02-02 & 74722 & $9 / 4 / 02$ & $2 \pi$ & $9 / 6 / 02$ & 2949.9 & 112 & $=$ & $=$ & $10 / 3102$ & 2945.6 & 161 \\
\hline ALG-02-02 & 74717 & $9 / 4 / 02$ & 40 & $9 / 6 / 02$ & 3081.9 & 11.7 & - & - & $10 / 3 / 02$ & 3076 & 10.3 \\
\hline
\end{tabular}

\section{Freeze/thaw instrumentation: CRREL}

The primary purposes of the CRREL instrumentation program were to evaluate: the monitoring of the soil freeze/ thaw characteristics in detail with depth, timing, and effects of any slope failures at the dewatered or control site; and the effects of dewatering on soil freeze/ thaw processes. The following paragraphs summarize the CRREL instruments installed at the dewatered and control sections of the MPS site. The reader is referred to Ferrick et al. (2005) for further instrument description. 
Moisture probes, resistivity probes, thermistor strings, and Web cameras were installed only at MPS. Webcams were mounted on poles to record daily surface changes, such as ice formation on the slope or lake and slumping of the slope's surface, which can be compared with downhole instrumentation data. Webcams allow 24-hour visual monitoring of the sites. Three photos of the test site and control site were taken over the course of each day. These photos, along with plots of instrumentation data, were available for observation daily at https://webcam.crrel.usace.army.mil/allegan/.

The other instruments were installed in six vertical holes, three at the control site and three at the test site of MPS. The holes were bored in the fall of 2003 and the following instruments were installed in May 2004: five soil moisture probes at two sites ( 10 total), two soil resistivity probes, and two thermistor strings with six thermistors per string (Ferrick et al. 2005) (Figure 38).

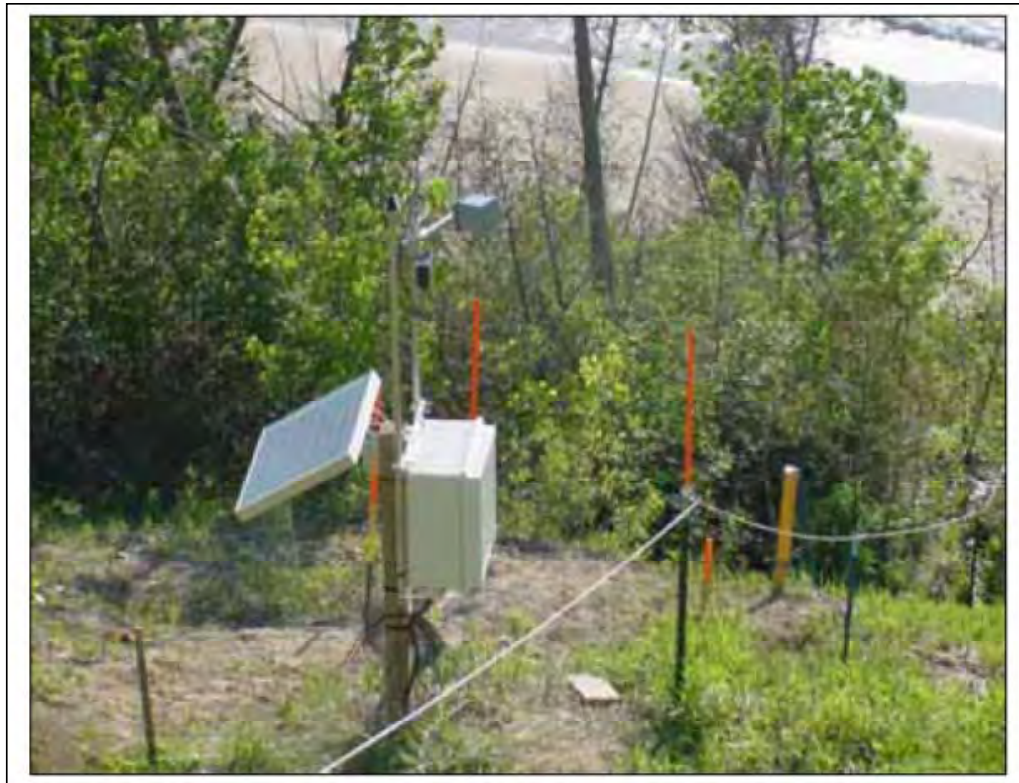

Figure 5. View from above of our site in a nearby control section of the bluff. Soil temperature, moisture, and resistivity instrument profiles in the bluff are marked by orange stakes, with solar panel, data logger, and web camera visible as a cluster in the foreground.

Figure 38. Soil moisture probes, soil resistivity probes, and thermistor strings installed in vertical borings, next to orange stakes. Web camera, data logger, and solar panel were installed as a cluster, foreground (Ferrick et al. 2005). 
Soil temperatures $\left({ }^{\circ} \mathrm{C}\right)$ were measured with thermistor temperature probes constructed at CRREL with a rated accuracy of $\pm 0.2^{\circ} \mathrm{C}$. These probes were mounted in PVC pipes and buried in the bluff so that thermistors monitored depths of $0.1,0.25,0.5,0.75,1.0,1.5$, and $2.0 \mathrm{~m}$. Volumetric, soil-water contents are obtained at five depths at each site, nominally $0.5,1,2.5,3.8$, and $5.4 \mathrm{~m}$. The lower portion of each probe provides soil moisture, and the upper portion gives soil temperature with a difference in depth of about $0.1 \mathrm{~m}$. Soil conditions at the dewatered and control sites were saturated below $1 \mathrm{~m}$ when the instruments were installed.

Soil resistivity (measured in volts) indicates the frozen or thawed state of the soil water. These profile probes were constructed at CRREL. Resistivity values near zero indicate liquid pore water, while larger values indicate increasing ice content. A total of 29 depth intervals are monitored, from $7 \mathrm{~cm}$ to $149 \mathrm{~cm}$, with a resolution of $5 \mathrm{~cm}$. Soil resistivity and temperature measurements are used in combination to define the depth of frost and the number and duration of soil freeze/ thaw cycles. These data indicate the time-history of freezing of the bluff.

Water contents were determined using a Vitel Hydra- Probe (Stevens Water Monitoring Systems, Inc., 5465 SW Western Ave., Suite F, Beaverton, OR 97005, www.stevenswater.com). Soil temperatures were determined with a Campbell Scientific 107 temperature probe, a thermistor with a rated accuracy of $0.1^{\circ} \mathrm{C}$ from -24 to $48^{\circ} \mathrm{C}$ (Ferrick et al. 2005). Soil sensor data were acquired continuously with Campbell Scientific CR10X data loggers (Campbell Scientific, Inc., 815 West 1800 North, Logan, UT 84321-1784, www.campbellsci.com). Data loggers also collected air temperature readings. 


\section{Results of Dewatering: 2004-2007}

To date, dewatering occurred during the two winter seasons of 2004-2005, and 2006-2007. No pumping or gravity draining was allowed during the 2005-2006 or 2007-2008 winter months. This chapter summarizes the data that were collected hourly during the period 2004 through 2007 at the three sites: MPS, MPN, and 116 th Avenue. During this period of demonstration, the bluff toe was minimally subjected to storm wave action.

The comparison of gross quantities of water extraction to bluff deformation and their temporal relations to ambient climate conditions are summarized. Data collected during the first year of dewatering support the previous conclusions, that an increase in piezometric levels of perched water tables occur subsequent to freezing ambient temperatures, and slope movement occurs subsequent to an increase in piezometric levels. The data from the remainder of the testing period 2005-2007, was inconclusive because of the warmer than usual winters and incidental well and instrument failures.

Soil temperature and resistivity data were recorded from 2004 to 2007, but only at the MPS site. These data were analyzed for the first year of dewatering (2004-2005) only. These data did not indicate freezing soil or water at the bluff face or with depth at the test site or control site at MPS. This is perplexing because frozen ground was observed at the site during this time. The soil temperature and resistivity instruments continued to capture data from 2005 through 2007; but, for lack of funding, analysis of these data has not been conducted.

\section{Results at MPS}

\section{4-2005 dewatering cycle}

Two sand layers in the bluff contain perched groundwater: a thinner upper sand (US) with multiple, thin, layers of lacustrine clay; and a thicker lower sand (LS) containing very little lacustrine clay. Dewatering began on 17 December 2004 and ceased 10 May 2005. During this period, a total of $250,770 \mathrm{gal}$ (an average of $1.2 \mathrm{gal} / \mathrm{min}$ ) of water were removed from the slump block. The mean shear displacement in the slump block section during the dewatering period was $2.8 \mathrm{in}$. The mean shear displacement in the control site during the same period was $11.5 \mathrm{in}$. Mean movement ratio 
is the control displacement versus dewatered displacement and equals 4.06 at MPS. Figure 39 shows displacements for Poles 4 and 8 in the dewatered test zone.

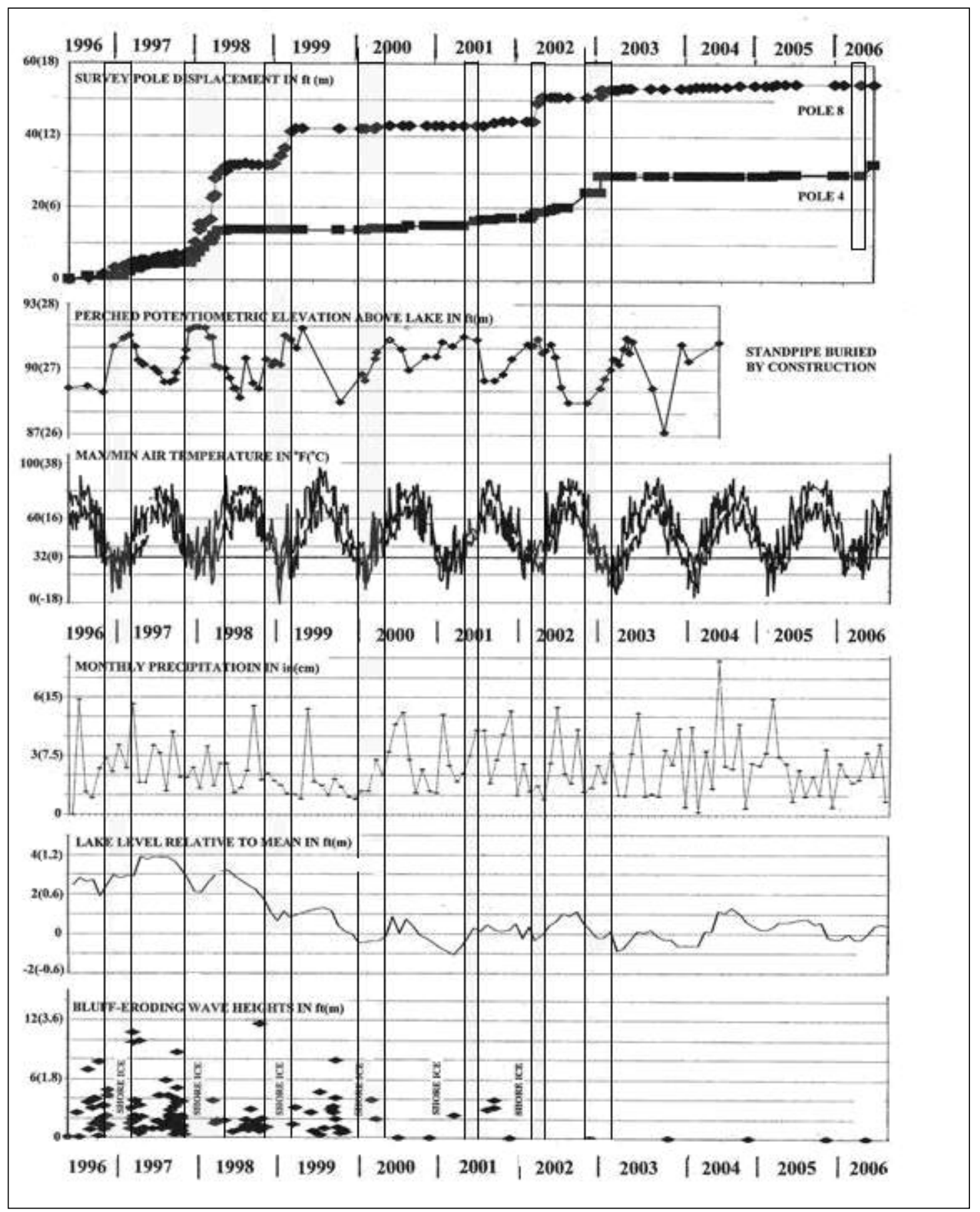

Figure 39. The pole (4 and 8 , in dewatered section of MPS) and cable (Line 2) data, plus all temporal relations regarding groundwater, climate, precipitation, and wave action, compiled through September 2006 at MPS. Dewatering cycle, November 2004-May 2005, showed marked decrease in pole movement (after Chase et al. 2007b). 
Piezometer levels fluctuated with bluff-face freeze/ thaw and periodic precipitation events. Overall, the average potentiometric levels in the dewatered zone remained steady throughout the pumping interval, while slightly yet steadily increasing in the control section. Inclinometer data showed most movement began after the first freeze (seen in eight of 12 inclinometer wells) and ceased the same day as the last freeze (seen in seven of 12 inclinometer wells). The preliminary results from MPS indicate that slope movement can be slowed with active dewatering.

\section{4-2005 freeze/thaw analysis results}

The purposes of the CRREL instruments were to record times of bluff-face freezing, depth of frozen pore water, soil temperatures and soil moistures. Webcam photos were not transmitted from MPS between late September 2004 and early April 2005. As a result, the snow cover or ice conditions and associated effects on monitored parameters through the winter are not available.

Air temperatures in November through mid-December (Figure 40), and again in February, generally were above freezing (Ferrick et al. 2005). Several brief periods with air temperatures below $-10^{\circ} \mathrm{C}$ occurred in midto late December, and again in mid- to late J anuary. Temperatures in J anuary 2005 averaged near $-10^{\circ} \mathrm{C}$, and around $0^{\circ} \mathrm{C}$ from February to mid-March 2005. Soil temperatures recorded by thermistor strings did not measure temperatures below freezing, except briefly at a depth of $0.1 \mathrm{~m}$ in J anuary 2005 in the control section. Winter soil temperatures (Figure 41) averaged between $0^{\circ}$ and $5^{\circ} \mathrm{C}$ from mid-December to mid-March in the first $0.5 \mathrm{~m}$ of the bluff surface.

Soil resistivity at both the control and dewatered sites did not deviate significantly from $0 \mathrm{~V}$ at any depth during the winter, indicating that soil freezing was limited to the upper $5 \mathrm{~cm}$ at the measurement locations. Air temperature data were collected at the data loggers of both sites and at the meteorological station located at the top of the bluff (Ferrick et al. 2005).

Soil moisture deviated greatly through the observation period (see Figure 42) and was affected by the pumping and precipitation. Analysis of the soil moisture data indicate all the soil moisture dynamics occurred in the upper $2 \mathrm{~m}$ of the soil column in both the dewatered and control sites. Soil moistures at depths greater than $2 \mathrm{~m}$ were high (near 40 percent) and stable at both sites. 

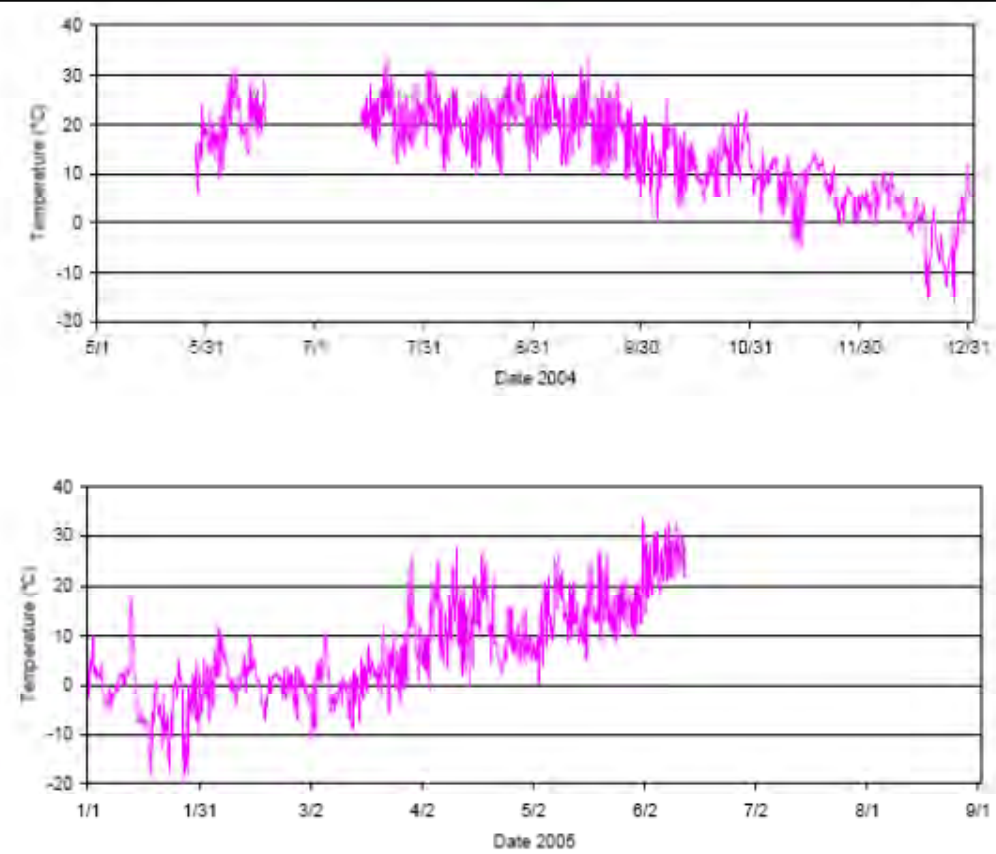

Figure 6. Logger/air temperature data from the remediated site, May 2004 into June 2005.

Figure 40. CRREL air temperature data, MPS, May 2004 to June 2005, recorded by data logger. This plot compares well to air temperature plotted by weather station at MPS. Data gap in June and July 2004 was because of an equipment setup error (Ferrick et al. 2005).

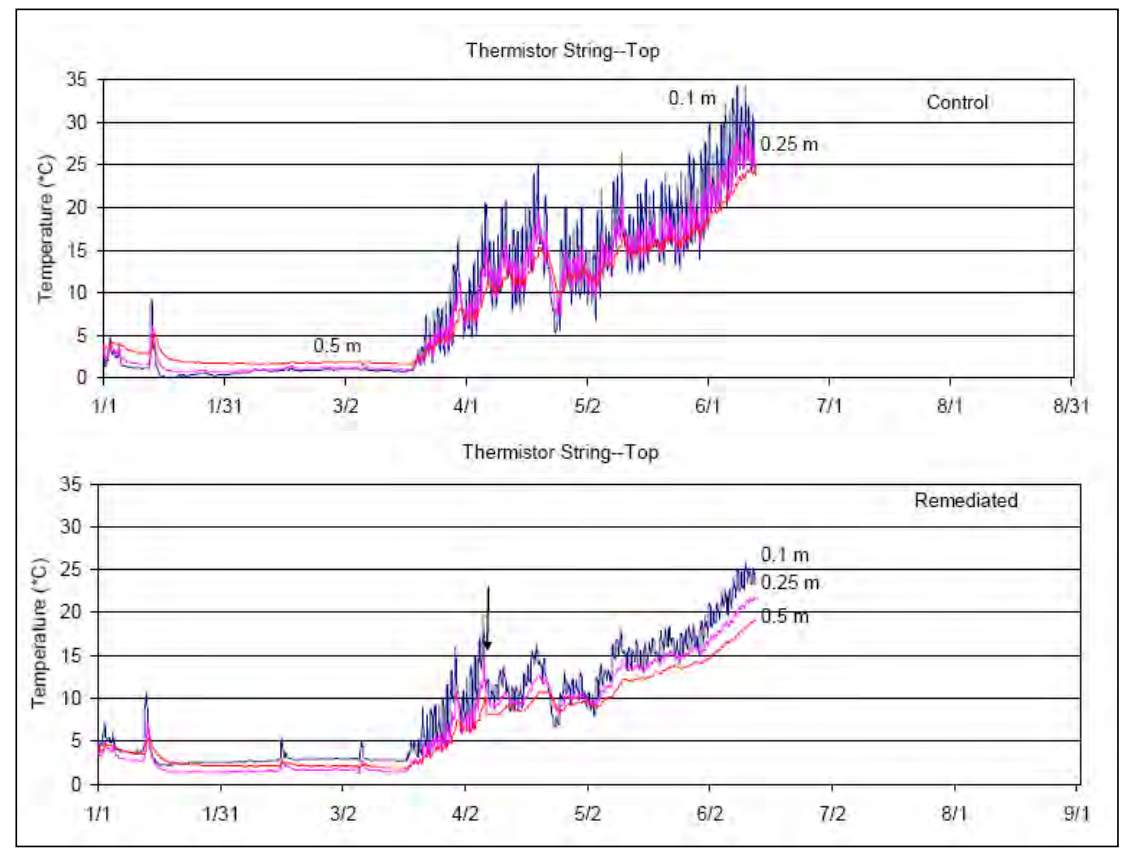

Figure 41. Soil temperature from thermistor strings, January to June 2005, for the dewatered and control sites at MPS (Ferrick et al. 2005). 


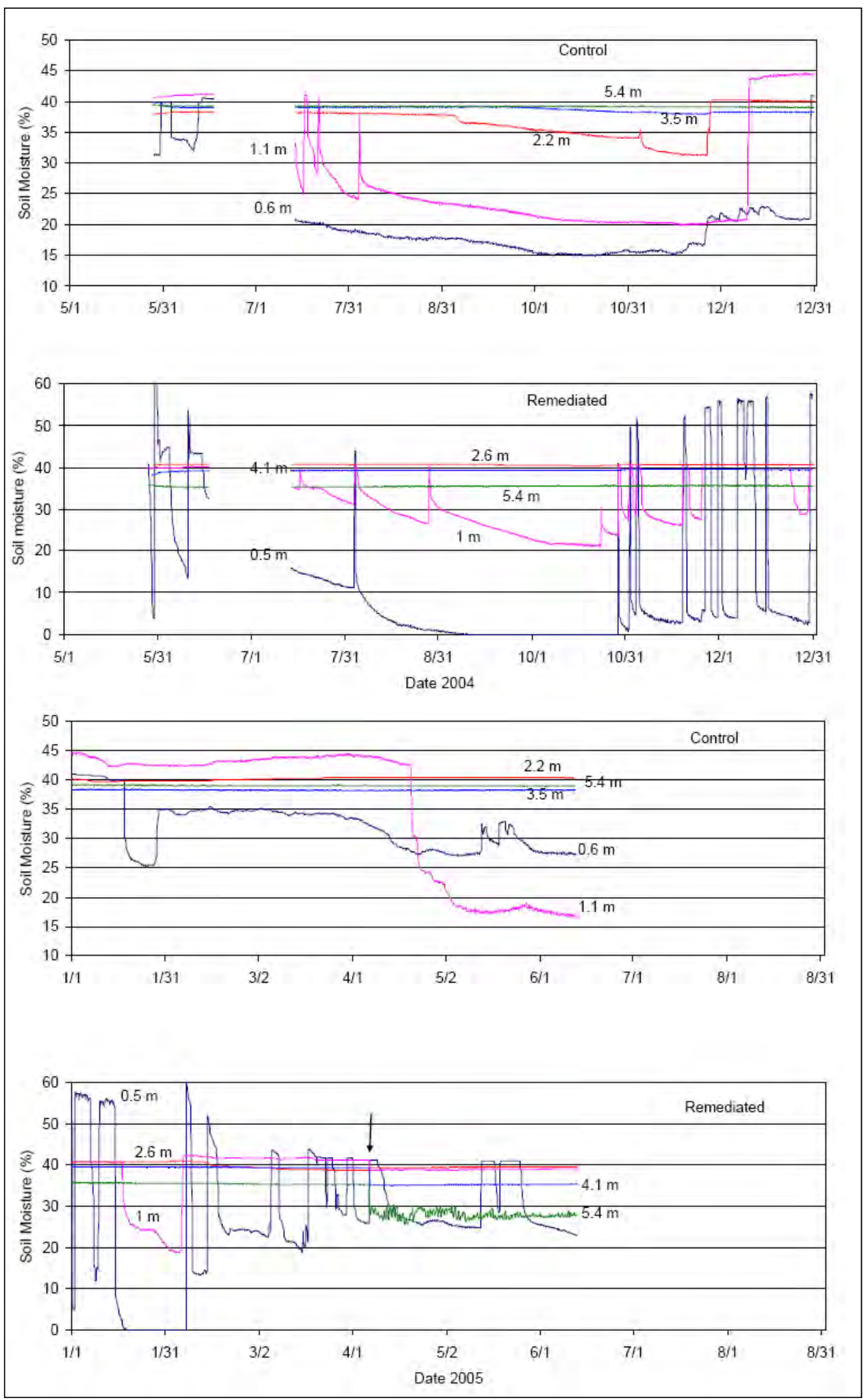

Figure 42. Soil moisture results from January to June 2004, top two plots; 2005 , bottom two plots. Note high variation in shallow depths at remediated site during dewatering (after Ferrick et al. 2005). 
The data exhibited evidence of two slope failures, one in the control area (8 March 2005) and one in the dewatered area (7 April 2005). The slope failures occurred near the 2-m depth in the control and dewatered sites, where the moistures were high. The soil moisture at this depth was not decreased by pumping, either before or after the 7 April event, in the dewatered site. When this failure occurred (7 April), the moistures below $2.6 \mathrm{~m}$ decreased abruptly at the dewatered site. It is assumed that the failure occurred at the depth of pumping influence and after the failure a connection was made between the pumps and the lower sensors at 4.1 and $5.4 \mathrm{~m}$.

\section{5-2006 no-dewatering, 2006-2007 dewatering cycles}

Surface displacements in the dewatering versus control sites were nearly the same, whether dewatering occurred or not, at the MPS site. For the winter/ spring of 2005-2006 no pumping occurred and displacements in the dewatering zone averaged $1.5 \mathrm{in}$. for all survey poles, while the control site averaged 1.6 in. During the 2006-2007 winter/ spring dewatering experiment, 93,711 gal of water were discharged; the dewatering site surface displacements averaged 3.6 in., and the control site averaged $2.7 \mathrm{in}$. Inclinometers showed downhole well profiles with little distortion (movement) during this period of dewatering.

\section{Results at MPN}

\section{4-2005 dewatering cycle}

No groundwater removal occurred. The eight vertical pumping wells at the base of the bluff did not activate because no precipitation event occurred that produced excessive recharge into the groundwater system. Passive removal of the groundwater using the horizontal well system was not effective because the wells either froze or were clogged by the in situ material. The installation of the horizontal passive wells did not include a filter pack, which normally accompanies a vertical well. The filter pack was too difficult to install because of the horizontal orientation. Groundwater potentiometric data have not been analyzed yet; therefore, correlation with pumping data or bluff movement data is not available.

In the dewatered zone, periodic and sudden bluff movements occurred 21 December 2004; and 12 J anuary, 17 and 23 February, and 27 March 2005. These displacement dates were recorded in the pole-and-cable systems and inclinometers. The sudden movements were localized to the 
northern half of the site. Cumulatively, these movements took out the three passive wells and the northernmost pumping well (W4). In addition, two monitoring wells were seriously displaced, resulting in the severing of cables for four inclinometers and one piezometer. The cables have been repaired.

Bluff movements in the control site were steady, such that several feet accumulated during the winter/ spring test interval. On a per-inclinometer or per-pole basis, more movement occurred in the control site than in the dewatering site. The control site showed displacements that were temporally more uniform because the sand layers that stored perched groundwater were somewhat higher in elevation above lake level and in more vulnerable locations relative to bluff stability. Although the control site showed displacements more consistently impressive than those in the dewatering site, the contrast is due more to stratigraphic considerations than to selective groundwater removal.

\section{5-2006 no-dewatering, 2006-2007 dewatering cycles}

During the period 2005-2007, meaningful dewatering experiments did not occur because catastrophic failures during the winter/ spring of 2004-2005 destroyed four dewatering wells and the remaining seven wells were not productive. Subsequently, sudden failures occurred in the southern sector of the site on or about 21 March 2007 that destroyed two inclinometer wells.

Several feet of bluff movement accumulated at MPN during the test period. Two local slumps developed in the proposed dewatered portion at the top of the bluff at locations where drainage wells were not present. Surface movements at the control site were about 10 times greater than in the dewatered area; however, minor differences in stratigraphy, not bluff dwatering, might be the explanation for this movement. In hindsight, placement of active vertical drains at the top of this bluff might have created an effective dewatering scheme at this site.

The dewatering experiment at MPN has not produced the desired data because: instrumentation and some dewatering wells have been detroyed by catastrophic slumping; the horizontal well system installed in alternating sand and clay layers in the upper sector of the bluff did not yield much water from the tight sand/ clay layers before they were destroyed; and the thick sand layers near the base of the bluff drained the groundwater too efficiently to be intercepted by wells. Groundwater and displacement data 
were collected but had not been analyzed at the time of this report. The displacement and groundwater data should reveal significant insight to the stratigraphic influences on displacement mechanics and groundwater transmissivity in alternating clay/ sand layers at MPN.

\section{Results at 116th Avenue}

\section{4-2005 dewatering cycle}

The slope to be dewatered is largely clay-rich till with local sand layers. The base of the slump block is quite shallow. The decision was made to dewater with horizontal, passive flow wells drilled about $25 \mathrm{ft}$ into the bluff face. Fifteen bluff-face wells and one bluff-top, slope-parallel horizontal well were constructed at the $116^{\text {th }}$ Avenue site.

Little groundwater removal occurred at the site. The cumulative water discharge was $139.5 \mathrm{gal}$. This low yield can be attributed to the relative impermeability of the clay being drained and possibly the inability of the gauges to read minute flow rates. Minor movements of a few inches at most occurred in incremental stages in the dewatered zone. Movement data have yet to be compared to ambient temperatures or piezometric levels. It is likely that the movements were timed with freeze/ thaw cycles, as was observed at MPS. The movement history at the control site differed little from the movement history at the dewatered site.

\section{5-2006 no-dewatering, 2006-2007 dewatering cycles}

Overall, during the 2005-2007 time frame, the dewatering site was more active than the control site at $116^{\text {th }}$. During the non-dewatering winter/ spring of 2005-2006, displacements reconded in the dewatering site by surface instruments accounted for an average of 11.4 in., versus no displacement in the control site. During the dewatering winter/ spring 2006-2007, $194.2 \mathrm{gal}$ of water were removed and surface displacements recorded at the dewatering site averaged $8.6 \mathrm{in}$., versus $3.5 \mathrm{in}$. in the control site.

The groundwater yield from bluff-face wells was disappointing. Although the bluff-top horizontal well was properly positioned to receive water perched on top of the upper clay layer, its yield also was minimal. However, more water was discharged than at MPN. Unlike MPN, the slope displacements were more consistent and less dramatic. 


\section{Summary of dewatering results}

Removal of perched groundwater at MPS during the winter-spring (conducted during 2004-2005) created a significantly more stable bluff than did the non-removal of groundwater over the same time interval. Compared with the winter/ spring of 2004-2005, when excellent data were gathered that demonstrated the effectiveness of vertical pumping systems operating in a freeze/ thaw environment, the winters/ springs of 20052006 (year of no pumping) and 2006-2007 (the second dewatering year) were anomalously warm and the freeze/ thaw cycles were fewer and generally shorter. Consequently, the comparisons of slope behaviors in dewatering sites versus control sites for these winter/ spring cycles do not reveal significant differences.

Generally, during the 2005-2007 period, the surface displacements at each site amounted to a few inches per winter/ spring cycle, (e.g., the in-place inclinometers mostly recorded ground rotations of fewer than 1 deg with no rapid displacements). In addition, the VWPs recorded potentiometric surface levels that fluctuated very little. The displacement distances in the dewatering versus control sites were influenced more by soil stratigraphy and geotechnical differences than by water quantity differences when the winter/ spring climate conditions are mild with fewer freeze/ thaw cycles of shorter duration.

The relationship between potentiometric surface rise during freeze cycles, rapid discharge of the stored water during thaw cycles, and deformation during both stages only can be demonstrated if winter air temperatures are low enough to completely freeze the soil surface and the soil remains frozen long enough to allow the pore pressures to rise. It is clear that a return in the future to the more normal winter/ spring conditions of 2004-2005 would benefit the dewatering experiment greatly. If normal winter/ spring conditions prevail, repeated experiments will feel whether the bluff stabilization shown in 2004-2005 is an equilibrium event or an anomaly.

Finally, the purpose of the CRREL resistivity instruments are to record times of bluff-face freezing, depth of frozen pore water, soil temperatures, and soil moistures. Analysis of the soil moisture data indicates all the soil moisture dynamics occurred in the upper $2 \mathrm{~m}$ of the soil column in both the dewatered and control sites. Soil moistures at depths greater than $2 \mathrm{~m}$ were high (near 40 percent) and stable at both sites (the control and test area at MPS). 
The MPS data exhibited evidence of two slope failures, one in the control area (8 March 2005) and one in the dewatered area (7 April 2005). The slope failures occurred near the 2-m depth in the control and dewatered sites, where the moistures were high. The soil moisture at this depth was not decreased by pumping, either before or after the 7 April event, in the dewatered site. When this failure occurred (7 April), the moistures below $2.6 \mathrm{~m}$ decreased abruptly at the dewatered site. It is assumed that the failure occurred at the local depth of pumping influence and, after the failure, a connection was made between the pumps and the lower sensors at 4.1 and $5.4 \mathrm{~m}$.

Analysis of the resistivity data shows no frozen pore water; however, observation of frozen ground was made down to $0.75 \mathrm{~m}$ during several site visits. It is perplexing that the resistivity probes did not indicate frozen groundwater or freezing temperatures when air temperatures were below freezing for prolonged periods during the 2004-2005 dewatering cycle. Additional comparisons of the freeze/ thaw data to ambient temperature and field observation should be conducted. Also, careful comparison of the soil moisture profile to the deformation analysis is strongly recommended. 


\section{MPS Groundwater Model: Overview}

The MPS site was selected for application of the groundwater. The purpose of the model is to evaluate (i.e., quantify) the effectiveness of the current pumping scheme to dewater the bluff face and to project the effectiveness of alternative schemes. The development of the model involved:

- Building the geologic layers according to known borehole data and interpreted cross sections;

- Building a computational mesh with element material properties being set according to available data;

- Assigning boundary conditions and source/ sink terms to the mesh;

- Calibrating:

o Steady-state water levels,

o Transient flux,

o Transient storage.

The accuracy of any model simulation depends upon a representative geologic and hydraulic conceptual model, in addition to realistic boundary conditions. The geologic conceptual model of MPS has been well documented and validated by Chase and Kehew, as described earlier in this report. The hydraulic model properties were estimated by limited aquifer testing (conducted in May 2004) and engineeringjudgment. Laboratory permeability tests also were conducted. The boundary conditions and source/ sink terms applied to the numerical mesh were representative of existing field conditions in May 2004. The development and results of the groundwater model are discussed in this chapter. The reader is referred to Hansen et al. (2007) for a complete description of the computational model.

\section{Model components}

\section{Boundaries}

The model built for the MPS site is roughly rectangular in shape. Figure 43 shows relative boundaries and applied boundary conditions. The western boundary coincides with the toe of the bluff. The eastern boundary is about $450 \mathrm{ft}$ inland from that location. The north and south boundaries were placed outside the area of the bluff-face monitoring piezometers and dewatering wells. The total area of the model domain is just fewer than 5 acres. 


\section{Boundary Conditions}

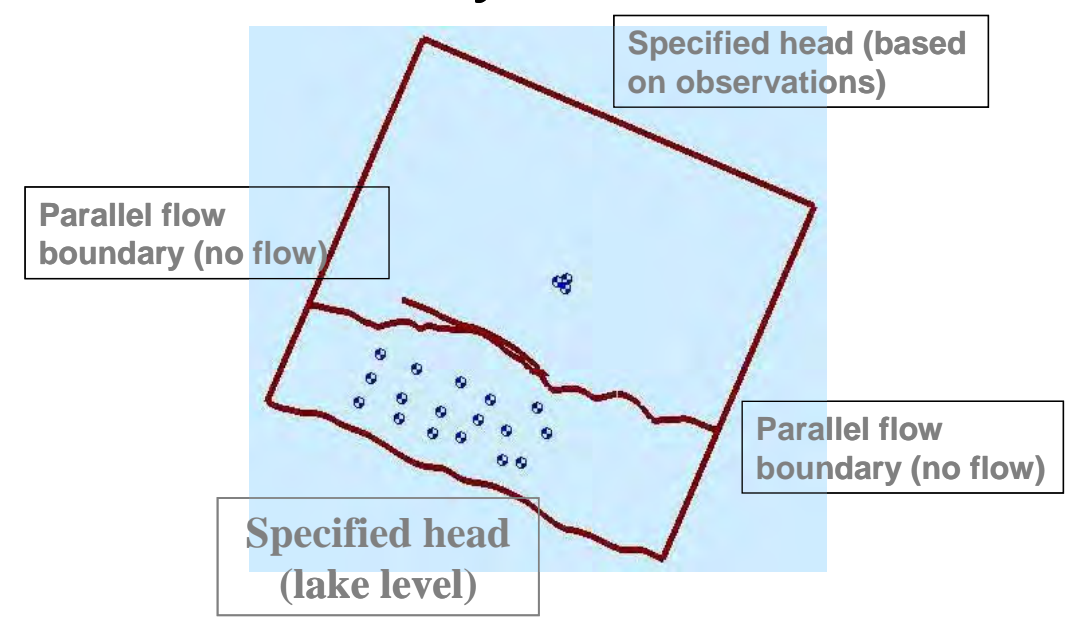

Figure 43. Illustration of numerical model's boundary conditions. Dimensions: length $\approx 450 \mathrm{ft}$, width $\approx 485 \mathrm{ft}$, and area $\approx 200,000 \mathrm{ft}^{2} \approx 4.9$ acres. Dewatering wells shown on the bluff face.

Piezometer ALG-02-01 in center of the model. Three circles in the middle of the model represent open standpipes used for modified slug tests.

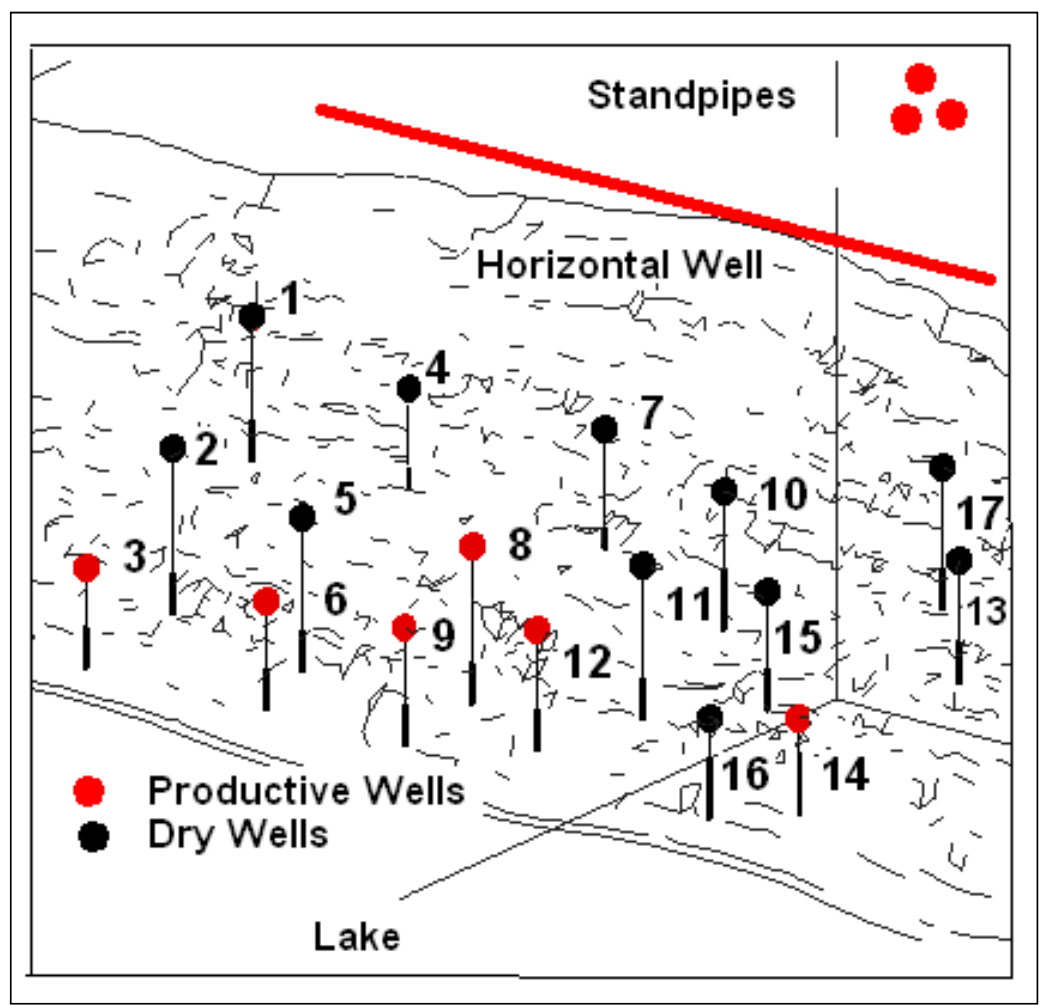

Figure 44. Extraction well locations. Red wells indicate productive pumping wells in May 2004. Black wells were dry in May 2004 (after Hansen et al. 2007). Note the upper-bluff wells are dry and lower-bluff wells are mostly wet (after Hansen et al. 2004). 


\section{Boundary conditions}

The boundary conditions were set assuming flow is perpendicular to the shoreline. The western boundary is a specified head boundary condition, set at $580 \mathrm{ft}$ (an average elevation for the lake level). The eastern boundary also has a specified head, but each of the sands has a slightly different head value. The specified heads on the intervening aquitards were interpolated between the aquifer heads. For the north and south ends, flow was assumed parallel to these boundaries and no flow was allowed to enter or leave (Hansen et al. 2007). The 17 pumping wells were modeled as sinks, and a small recharge was applied to the ground surface.

\section{Material layers}

The model layers in the slumped area of the bluff were based on the five balanced cross sections developed by Chase, as well as corresponding pole-and-cable survey lines. The stratigraphy representing the undisturbed layers (located inland from the slump) was based on data from the rotosonic boring $\log$ AL-02-01. The rotosonic boring was continuously sampled and provided a complete lithologic record from the top of the bluff to below the toe.

Seven material types were identified from the top of the bluff to the lake level, as listed in Table 5 and represented in the model. The eighth material is a gouge (shear) material that lines the deepest slip surface in the slumped area. The stratigraphy creates three distinct aquifers with associated water tables: Sand 1, Sand 2, and Sand 3; the lowest (Sand 3) is hydraulically connected to Lake Michigan. The upper two water tables release water at several seep points on the bluff face, as shown in Figure 9.

Table 5. Final material layers thicknesses and boundary conditions (Hansen et al. 2004).

\begin{tabular}{|l|l|l|}
\hline Material & Average Layer Thickness (el, ft) & Upstream Specified Head (ft) \\
\hline Diamicton & $670-640$ & 682.0 \\
\hline Clay 1 & $640-625$ & 631.0 \\
\hline Sand 1 & $625-620$ & 580.0 \\
\hline Clay 2 & $620-615$ & --- \\
\hline Sand 2 & $615-595$ & 593.0 \\
\hline Clay 3 & $595-580$ & 598.5 \\
\hline Sand 3 & $580-?$ & 604.0 \\
\hline Smear & $4 a$ & --- \\
\hline
\end{tabular}

a Thickness of shear material along slip surface, not an elevation. 


\section{Subsurface geometry and topography}

The slumped geometry of the bluff was modeled after the five cross sections developed by Chase, from the five pole-and-cable survey lines at MPS (Figure 21). The bluff face (ground surface) was surveyed by a team led by Chase, and the resulting topographic map (Figure 10) was used in creating a triangulated irregular network (TIN) of the ground surface for the model (Figure 45).

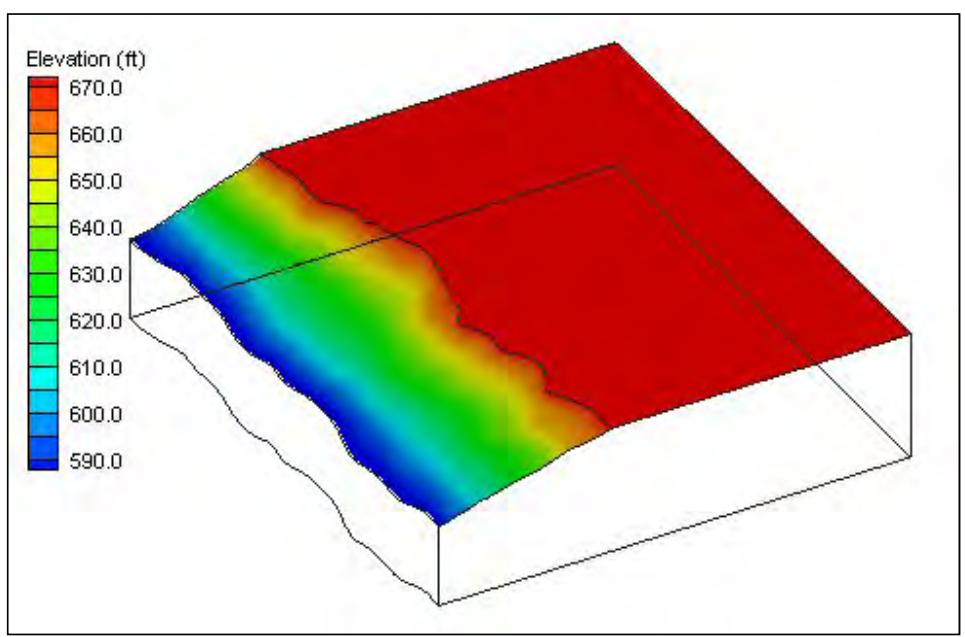

Figure 45. TIN describing the ground surface (Hansen et al. 2004).

Figure 46 illustrates the stratigraphic data and location of the instrumentation boreholes, as represented in the model. Once the TINs and boreholes were entered with the correct horizons, the Department of Defense Groundwater Modeling System (D.DGMS) was able to create a three-dimensional (3-D) computational mesh in a single step. The final mesh is shown in Figures 47 and 48. The mesh has 124,786 nodes and 693,691 tetrahedral elements. Mesh construction was a difficult task completed with tools derived at ERDC specifically for this demonstration project. (Hansen et al. 2007).

\section{Selection of modeling code}

Selection was based on the complexity of this site, specifically the existence of three water-bearing layers, two of which seep through the surface. The multiple water tables existing at this site preclude the use of some common flow models. Selected was the ADaptive Hydrology (ADH) groundwater modeling code, developed at ERDC by Schmidt (1995) and Howington et al. (1999). 


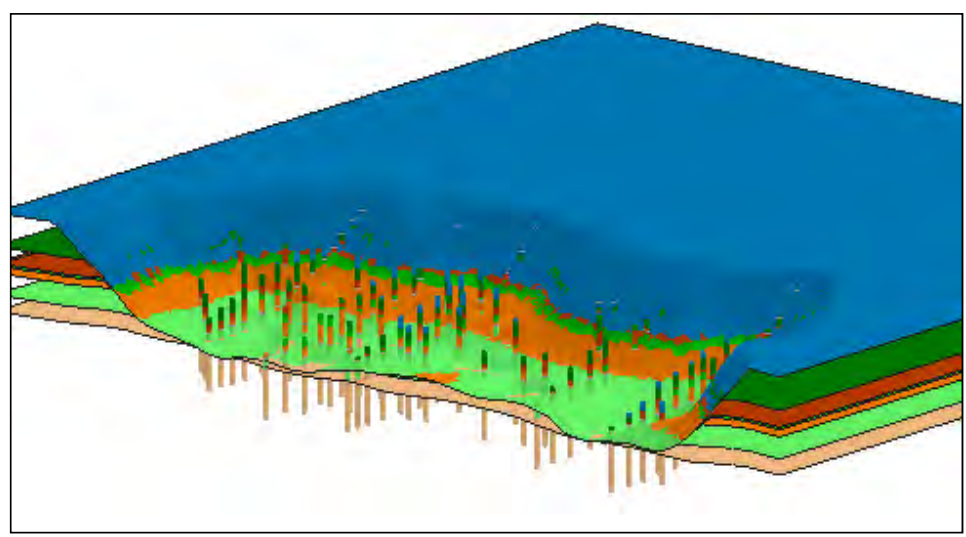

Figure 46. Figure showing borehole location and corresponding stratigraphic information applied to the groundwater model

(Hansen et al. 2004).

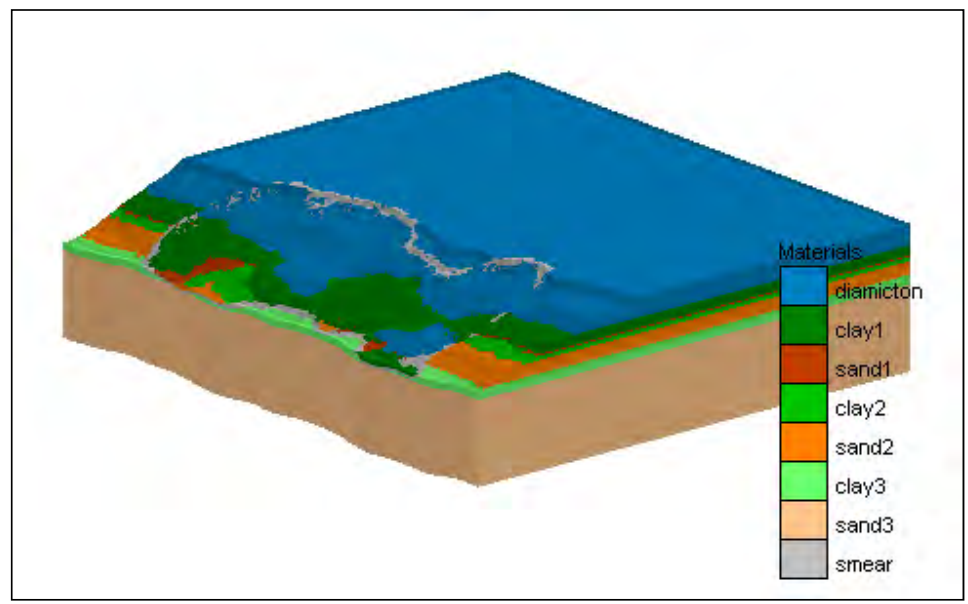

Figure 47. Finished computational mesh with material types assigned (Hansen et al. 2004).

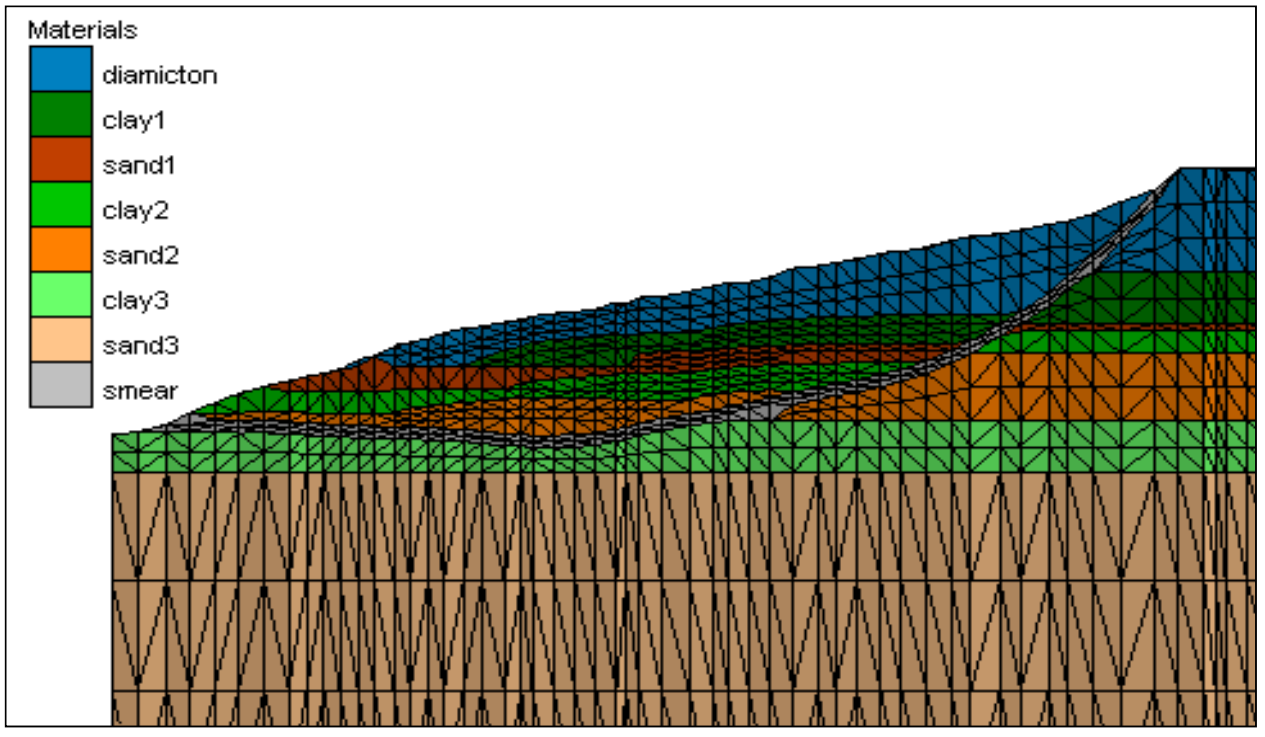

Figure 48. Typical cross section of finished computational mesh. The mesh has 124,786 nodes and 693,691 tetrahedral elements (Hansen et al. 2004). 
This code accommodates saturated and unsaturated groundwater flow, and groundwater-surface interaction. The solutions to the governing equations use the finite element method applied to unstructured computational meshes (Hansen et al. 2007). An unstructured mesh can simulate complex material distribution, better than the more commonly used structured mesh. The interface used to set up the model and view the results is the D.DGMS.

The selection of the modeling code also was based on a long-term goal of this demonstration project. Future plans for the numerical model include coupling it with a large deformation model and a heat transport model to develop an advanced and more realistic model of the failure mechanism. New techniques will include progressive slope failure modeling with a deforming mesh model.

\section{Groundwater aquifer tests: May 2004 at MPS}

\section{Introduction}

Field tests were conducted to estimate aquifer properties at MPS and to assist in model calibration. Before the first dewatering cycle began in December 2004, the following aquifer tests were conducted: modified slug, and individual and collective pumping. The tests included measurement of actual static heads, transient heads, flow rates, and recovery rates in the field piezometers. As part of the dewatering demonstration, 17 pumping wells were activated, and 14 piezometers on the bluff face were monitored (STS 2005) at MPS. Static and transient water level responses also were measured in the three piezometers (open standpipes) installed by Montgomery (1996). A thorough description of the aquifer testing by Hansen (2004) is in Appendix D.

\section{Modified slug tests}

Slug tests were run in the three standpipes located $75 \mathrm{ft}$ behind the bluff face and installed by Montgomery (1996). A flow meter was connected to the end of a hose and the water was turned on full for about $30 \mathrm{~min}$, discharging to the deep and middle standpipes. An immersible water-level data logger (Levelogger) was placed in each standpipe to measure head of water before, during, and after the slug was added. The logged data showed a rapid increase in head when the water was first added to the pipe (Step 1), followed by a steady-state condition when the amount going in was matched 
by the water flowing into the screened interval of the aquifer (Step 2), and a quick drop when the water was turned off (Step 3) (Hansen et al. 2007).

The shallowest standpipe had standing water near the ground surface at the beginning of the test. Thus, it was not possible to conduct the first and second steps of the slug test because the standpipe overflowed before a steady-state condition could be achieved. However, the recovery stage of the test was measured by the Levelogger when the hose was turned off, allowing transient water level data to be recorded. Aquifer intervals and corresponding materials tested in each standpipe are shown in Table 6. All three standpipes are $2 \mathrm{in}$. in diameter.

Table 6. Details of modified slug tests conducted in standpipes.

\begin{tabular}{|l|l|l|}
\hline Standpipe & $\begin{array}{l}\text { Screened Interval } \\
\text { (ft from the ground surface) }\end{array}$ & Geologic Layer Tested \\
\hline Shallowest & $13-19$ & Diamicton \\
\hline Middle & $65-86$ & Middle sand \\
\hline Deepest & $94-129$ & Lower sand (hydraulically connected to the lake) \\
\hline
\end{tabular}

\section{Individual pumping tests}

These were conducted to determine possible extraction rates and to observe the extent of aquifer responses to individual pumps. The spring of May 2004 was dry, and only some of the extraction wells had water in them. All the top tier wells $(1,4,7,10,13$, and 17) were dry. Most of the middle tier wells $(2,5,11$, and 15) also were dry. The bottom tier wells (3, 6, 9, 12, and 14) and middle tier well (8) all had enough water in them for pumping. Well 16 was the only dry, bottom tier well (see Figure 44 for well locations; Hansen et al. 2007.) Pumping tests were conducted on the wet wells. The results are shown in Table 7.

Table 7. Individual field-test, flow-rate values for productive extraction wells (Hansen et al. 2007).

\begin{tabular}{|l|l|}
\hline Extraction Well & Flow Rate from Field Testing $\left(\mathrm{ft}^{3} / \mathrm{d}\right)$ \\
\hline 3 & 78.9 \\
\hline 6 & 59.6 \\
\hline 8 & 44.3 \\
\hline 9 & 57.7 \\
\hline 12 & 9.6 \\
\hline 14 & 42.3 \\
\hline
\end{tabular}




\section{Collective pumping test}

A 2-hr pump test was conducted with all the wet wells operating at once. A description is in Appendix D. The piezometers on the bluff face recorded measurements throughout the pumping period. This test measured piezometer response to active dewatering. The data from this test are compared to the calculated aquifer response from a 2-hr simulated pumping test to validate the model. The locations of the piezometers in relation to the pumps are shown in Figure 49. Piezometers 8 and 9 have two probes set at different depths, for a total of 14 operating piezometers.

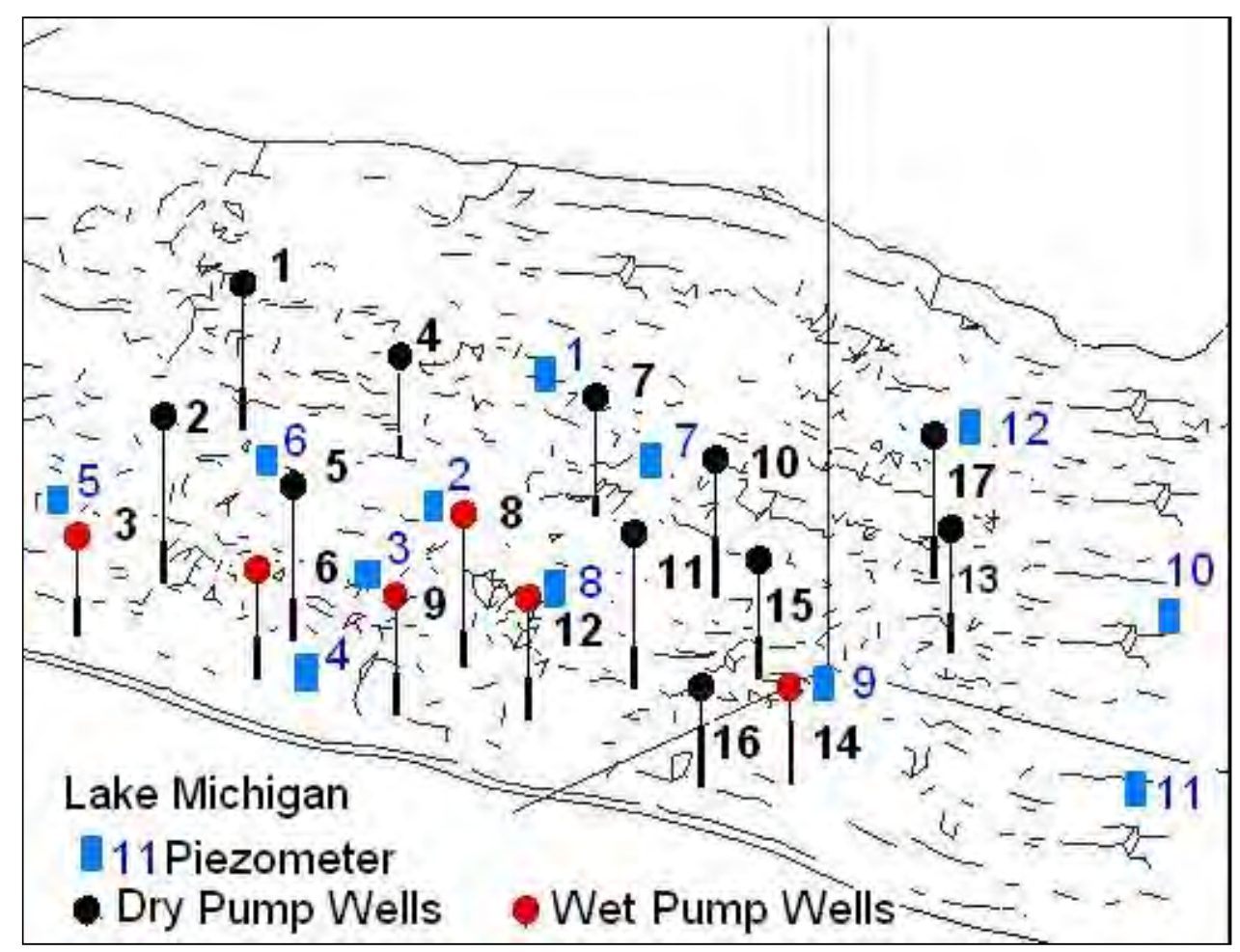

Figure 49. Piezometers and wells on bluff face (Hansen et al. 2007) combine the two figures above (Hansen et al. 2004).

\section{Calibration process and results}

\section{Calibration process}

This involves matching simulated steady-state water levels in the model with the in situ values measured in the field with no stress on the aquifer (i.e., no pumping). In addition, calibration required matching steady-state water levels, transient water levels, and transient flux values with those measured while stressing the aquifer (i.e., during the slug tests). The first 
step was achieved by varying the upstream head boundary conditions and conductivity values in the model.

The next step was to pair field responses to the slug tests. The steady-state values measured during the slug tests were matched by varying the hydraulic conductivities estimated in the first step. To verify the estimated hydraulic conductivities, the calculated flux rate is compared to the actual flux during the slug test. This step is iterated.

The final step is to calibrate the storage coefficients by matching the calculated-versus-measured transient water levels during the recovery period of the slug tests. With the upstream boundary condition and hydraulic conductivity values fixed from Steps 1 and 2, the storage coefficients were varied until the water levels were matched.

\section{Calibration results (excerpt from Hansen et al. 2007)}

The final selections for the parameter values based on the calibration results are listed in Table 8. Most of the values are within accepted ranges for the material types. The diamicton conductivity and storage values seem too high for a clay-rich till, but the values probably are accurate because of vertical, sand-lined, shrinkage cracks documented by Chase (1990) that create a significant secondary porosity. Further, because this is the surface material, it easily could be affected by rocks, plant matter, human activities, etc. With the exception of the middle pump test recovery, and to a lesser extent the deep pump test recovery, the comparisons between the model results and the field measured data are encouraging.

Table 8. Final calibrated parameter values for the model (after Hansen et al. 2007).

\begin{tabular}{|l|l|l|l|l|}
\hline Material & $\begin{array}{l}\text { Horizontal Hydraulic } \\
\text { Conductivity (ft/d) }\end{array}$ & $\begin{array}{l}\text { Vertical Hydraulic } \\
\text { Conductivity (ft/d) }\end{array}$ & $\begin{array}{l}\text { Specific Storage } \\
\text { (unitless) }\end{array}$ & $\begin{array}{l}\text { Upstream } \\
\text { Specified Head (ft) }\end{array}$ \\
\hline Diamicton & 4.0 & 40.0 & $4.0 \mathrm{e}-2$ & 682.0 \\
\hline Clay 1 & 0.001 & 0.0001 & $1.0 \mathrm{e}-4$ & 631.0 \\
\hline Sand 1 & 28.3 & 28.3 & $1.0 \mathrm{e}-5$ & 580.0 \\
\hline Clay 2 & 0.001 & 0.0001 & $1.0 \mathrm{e}-4$ & -- \\
\hline Sand 2 & 40.0 & 40.0 & $1.0 \mathrm{e}-4$ & 593.0 \\
\hline Clay 3 & 0.0001 & 0.0001 & $1.0 \mathrm{e}-4$ & 598.5 \\
\hline Sand 3 & 0.7 & 0.7 & $1.0 \mathrm{e}-6$ & 604.0 \\
\hline Smear & 0.0001 & 0.0001 & $1.0 \mathrm{e}-4$ & -- \\
\hline
\end{tabular}


In addition to the good similarity between field measurements and model output, the model also correctly predicts seepage locations on the bluff face, shown as dark blue areas in Figure 50. Seepage areas occur at the bottom of a conductive layer when underlaid by a nonconductive area.

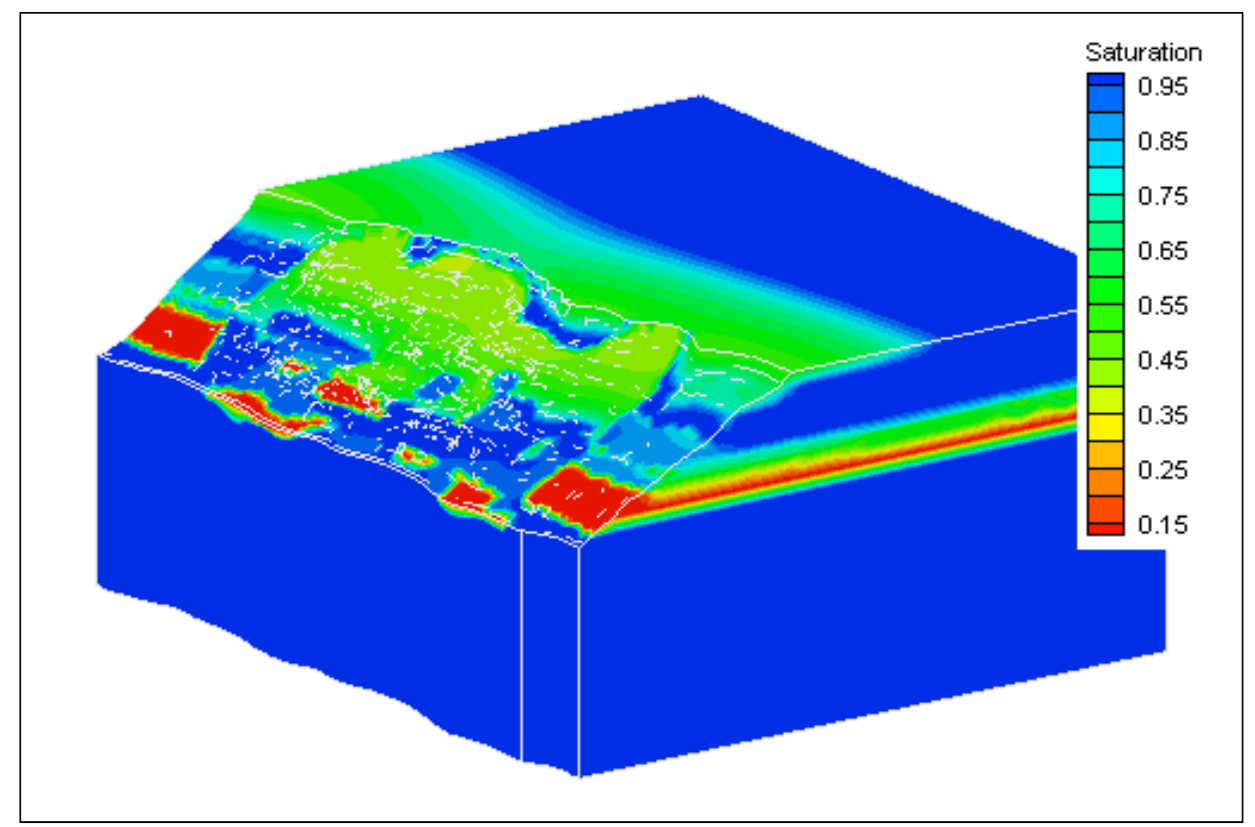

Figure 50. Model correctly locates flow from the bluff face above low permeable layers that contact higher permeable layers (sand) (Hansen et al. 2004).

\section{Pumping test simulations}

A short-term simulation was run to model the 2-hr pumping test conducted in the field in May 2004. Piezometer head values were compared to measured field values. The comparisons are similar. Two piezometers ( 2 and 3 ) had a smaller change in the field, and three piezometers ( 7,8 deep,and 9 shallow) had a greater change in the field compared to that predicted by the model.

The connectivity between the well and piezometer locations and the sizes of the sections of conductive materials can cause large differences in the influence of the extraction wells. Although storage and conductivity values have an effect on the pumping results, most of these values already have been calibrated sufficiently using the tests run behind the bluff.

The degree of similarity in the plots is mostly dependent on the correctness of the geology in the bluff. The geology is based mostly on an interpolation of five cross-sectional drawings. This short-term pumping test can reveal how well that interpolation reproduced the actual conditions in the bluff. 


\section{Long-term simulation: 100 days}

A final run was made to determine the long-term effects of the dewatering scheme on the bluff in these conditions. The tests were run for 100 days, slightly more than three months. Initially, the pumping rates were set according to those measured in the field during testing in May 2004. However, in almost all cases, these rates proved to be too high for a longterm test and gradually were dropped until the well remained wet during the entire period. The rates are listed in Table 9. Only Wells 6 and 8 were able to maintain significant extraction rates for the longer period.

Table 9. Comparison of field measured extraction rates during the 2-hr test and the values used in the model during the 100-day run.

\begin{tabular}{|l|l|l|}
\hline Extraction Well & $\begin{array}{l}\text { Flow Rate from Field Testing } \\
(\mathrm{ft} 3 / \mathrm{d})\end{array}$ & $\begin{array}{l}\text { Flow Rate Used in the Long-term } \\
\text { Pumping Run }(\mathrm{ft} 3 / \mathrm{d})\end{array}$ \\
\hline 3 & 78.925 & 0.0 \\
\hline 6 & 59.675 & 60.0 \\
\hline 8 & 44.275 & 20.0 \\
\hline 9 & 57.75 & 0.0 \\
\hline 12 & 9.625 & 0.0 \\
\hline 14 & 42.35 & 1.0 \\
\hline
\end{tabular}

\section{General comments on the numerical model}

Development of a model such as the MPS groundwater one is a difficult task. First, the glacial geology creates a heterogeneous environment made worse by the mass-wasting processes occurring near the bluff. Multiple water tables exist and are perched. Flow paths (i.e., contiguous permeable units) are irregular and cut off easily. Also, the bluff surface is erratic and difficult to reproduce in a model. Because so many readings and so much effort has been spent developing a detailed geologic interpretation and because of the access to advanced groundwater models and software, an excellent model has been developed. However, it was developed before the results of the first year of dewatering were available. Therefore, a final calibration and evaluation using the actual dewatering data was not possible but should be done.

The Hansen et al. (2007) report concludes that the model does not predict the hoped-for effect on the groundwater conditions because the wells have insufficient spatial influence. The empirical data expresses a strong correlation between freezing temperatures, high piezometric levels in perched 
water tables and slowed bluff movement with dewatering. The contradiction between the model and empirical results exists because the model was run in a dry period and the demonstration was run when there was much more water in the system. Thus, the modeled period was not comparable to the 2004-2005 winter. Additional calibration and validation of the current model is needed to test the model under conditions representative of winter (wet conditions).

With the many hourly readings collected from 2004 through 2007, this is a rare opportunity to conduct advanced research. Much could be gained from a complete review of the field data, using the model as an analysis tool. It could be that more pumps with smaller flow rates would be better suited for the MPS site. Two, yearlong analyses need to be made, one with the pumping on and one with all pumps off (i.e., without wells). In addition, intense comparisons between bluff movements and groundwater conditions should be conducted. Such a comparison is needed to begin the task of coupling the large deformation model and a heat transport model to the groundwater model. The new model would better represent the actual bluff failure mechanism.

\section{Technical knowledge transfer}

Included in the goals of the National Shoreline Erosion Control Development and Demonstration Program is the written transfer of knowledge gained from demonstration projects to the public. Numerous written documents and conference presentations have been made describing the Allegan County demonstration sites since the beginning of the initial project in 1996 and since the inception of ERDC funding in 2001. A bibliography of papers, journal articles, book chapters, and presentations is in Appendix E.

A direct application of the Allegan bluff dewatering technology has been used at the Mosel Bluff Section 14 project in Sheboygan County, Wisconsin, on the west coast of Lake Michigan (Figure 51) (Personal communication, Ross, USACE, Detroit District, J uly 2005). The bluff is seeping water at the toe and approximately $10 \mathrm{ft}$ downslope from its crest. Numerous attempts to stop the slumping and subsequent erosion have been made by adding riprap, as shown in Figure 51. The added riprap protection was unsuccessful at stopping the slumping of the bluff and undermining of the road (Lake Shore Road) atop the crest. Another technology was needed to stabilize the bluff. 


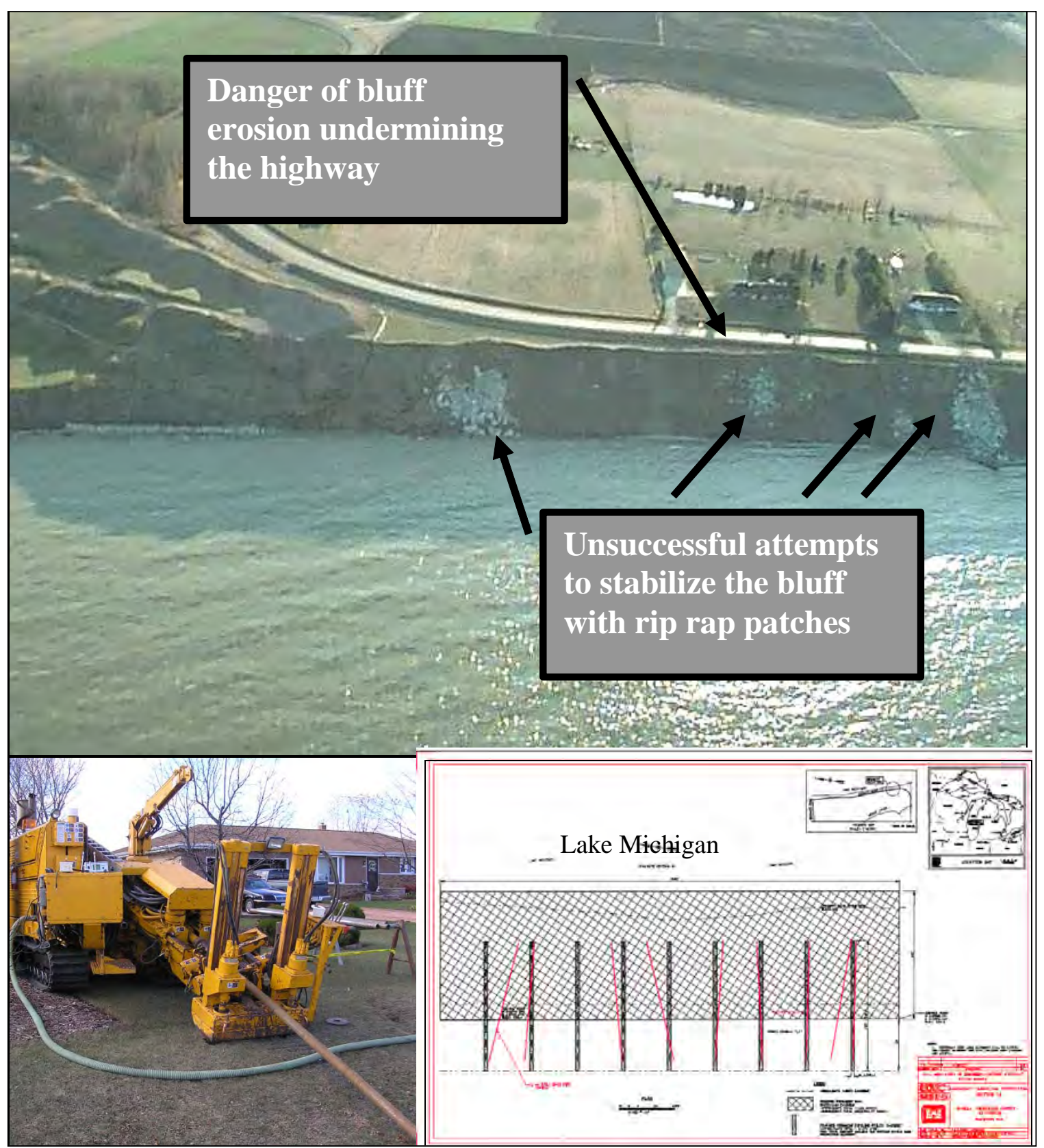

Figure 51. Mosel Bluff, clockwise from top, Lake Shore Road, Sheboygan County Wisconsin; directional drill rig atop Mosel Bluff and landside of Lake Shore Road; and as-built, plan view: nine directionally drilled drains from landside of Lake Shore Road to bluff toe (photos courtesy of Ross, USACE Detroit District; as-built courtesy of USACE, Detroit District).

The District drilled soil borings to determine the sequence and thicknesses of the clay, till, and sand layers. Nine directionally drilled drains were installed below the bluff surface and down dip of the bluff, from the crest to the toe. Figure 51 shows the drill rig across the road from the crest and the plan view of the drains as-built. The drains were perforated at the sand layers to allow bluff water to exit by gravity down the PVC to exit on the 
revetment at the toe. The length of the bluff being protected is $500 \mathrm{ft}$, and the bluff height is $55 \mathrm{ft}$. A robust revetment at the toe was constructed to combat wave action erosion (Figure 52).

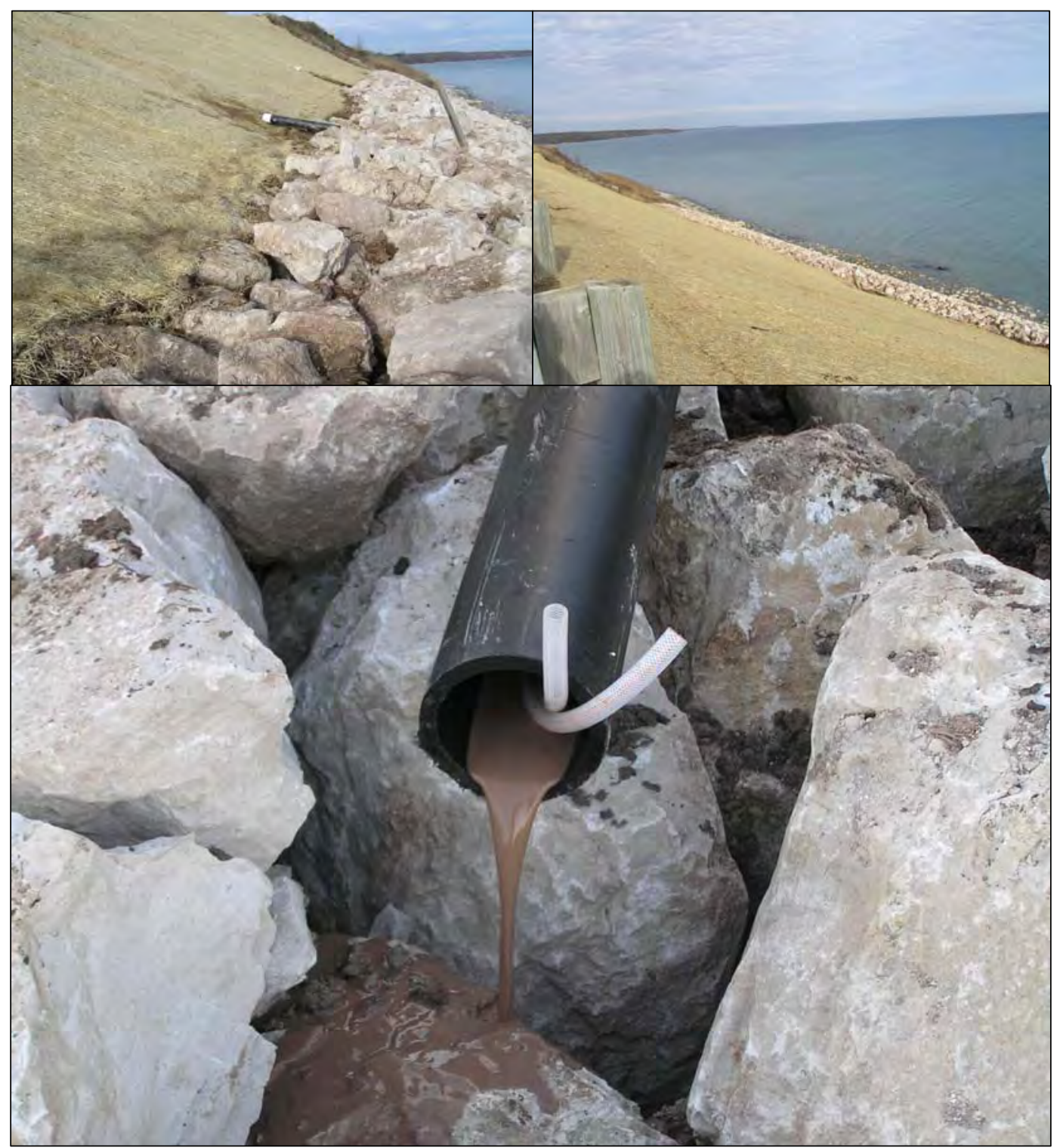

Figure 52. Slope, clockwise from top left, after cut and fill of the surface material; installation of gravity drains and toe revetment; and view of drain outlet at the revetment just after construction (photos courtesy of Ross, USACE, Detroit District).

The project at Mosel was installed in J anuary 2005. There was some initial slumping of the soil, which was used as fill to smooth and seed the slope surface. The failure plane coincided with the cut/ fill interface and did not penetrate the cut face of the bluff. The fill material was replaced and is now stable. The dewatering pipes are trickling water, seemingly consistently, based on site visits from time to time (Personal communication, Ross, 
USACE, Detroit District, 2005). There are no flow meters attached to the drains therefore correlation of water drained to precipitation events has not been made. However, in winter the drains freeze.

It seems that the Mosel project has been a success, with little movement observed since the initial construction and subsequent slumping in early 2005. However, the winters of 2006 and 2007 were mild in comparison to 2004-2005, and little movement was documented at Allegan during the winters from 2005-2007. Therefore, it is difficult to assume success at Mosel based on the atypical winters of 2006 and 2007. The movement of early 2005 might have been caused by freezing (clogging) of the drains with subsequent thawing and leakage around the outside of the drain pipes before thawing had occurred within the pipe. This leakage might have concentrated along the cut/ fill interface and caused the liquefaction and slumping of the fill material. The movements at these two bluffs have not been correlated, and this effort was not in the scope of the current investigation. However, continued monitoring at Mosel could validate the freeze/ thaw theories indicated by the Allegan demonstration. Figure 53 illustrates the bluff condition in 2005.

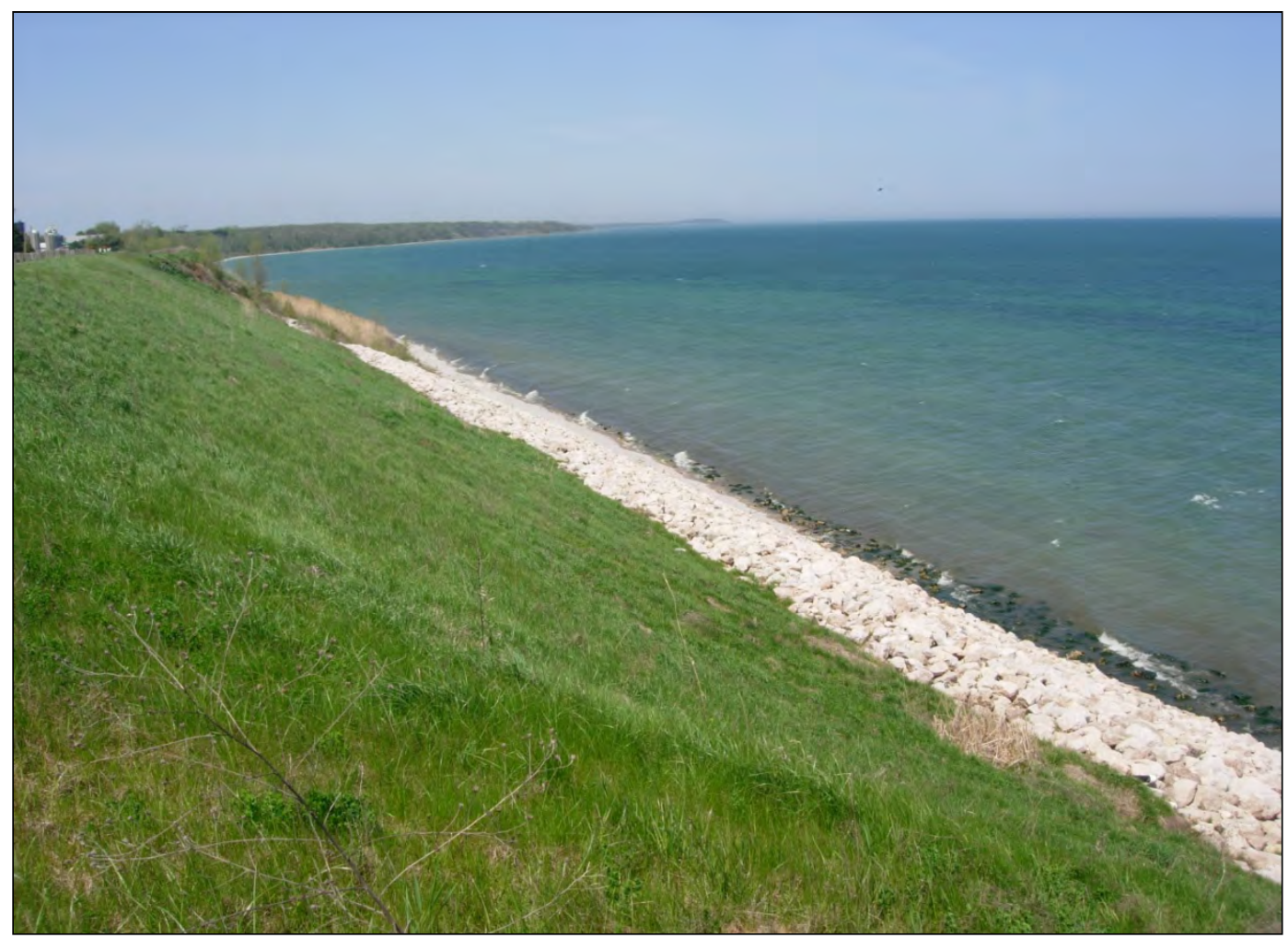

Figure 53. View after construction of gravity drained Mosel Bluff, Sheboygan County, Wisconsin. Note heavily constructed revetment at toe to prevent foreshore erosion (photos courtesy of Ross, USACE, Detroit District). 


\section{Allegan County project status}

The original plan called for five seasonal cycles of dewatering tests. USACE (and WMU matching) funding ceased at the end of the third cycle. The first winter-spring of dewatering (2004-2005), initiated after the completion of construction, proved successful. During a hard winter, dewatering reduced the cumulative downhill displacement of coastal bluff materials by approximately 400 percent at the MPS site. During the soft second and third winters (2005-2006 and 2006-07) when freeze-thaw cycles were few and short, the dewatering strategy was not sufficiently tested. No significant conclusions could be produced.

At the time of this report, no conclusion could be made concerning the success of bluff dewatering as a mitigation strategy. Bluff dewatering as a long-term mitigation strategy for coastal bluff stabilization has not yet been scientifically demonstrated. The data set needed to evaluate dewatering strategies through statistical treatments such as regression analyses, correlation coefficients, and error analysis will not be fully available until the dewatering phase of the project is complete. If reactivated, the project must run through two more seasonal cycles plus a one-year period to analyze data and prepare reports.

This research provides an unprecedented volume of data for characterizing the mechanics of bluff failure along Lake Michigan's coast. Forty-five dewatering wells have been installed and equipped with pumps or gravity drain valve systems within the three study areas. The bluff movements were monitored with 13 ground survey lines, 76 in-place inclinometers positioned in 26 wells, and 28 VWPs that reconded groundwater elevation data on an hourly basis. Additional data sets include readings from 45 water discharge flow meters, 103 downhole thermistors, 58 resistivity probes, 10 soil moisture probes, and meteorological data from two on-site weather stations. Detailed site characterization data includes geometrical and geological mapping activities at three sites, topographic and bathymetric surveys, aerial photography, and digital elevation models.

The project was shut down in mid-J anuary 2008, and future funding has not been authorized. All survey lines, instruments, and pumps have been left in place. The idle field equipment has been inspected periodically to detect damage from weather, slope displacements, or vandalism. The most recent inspection, March 3, 2009, showed no visible damage. 
Future research proposed for the demonstration project includes enhancing the groundwater model by coupling it with a large deformation model and a heat transport model. The enhanced model would not rely on a defined failure mechanism, such as a limit equilibrium model, but would simulate a realistic failure. The model would be capable of simulating the actual deformation of the bluffs (formation of slumps) with the changes in groundwater levels and temperature. Proposed numerical techniques include development of a discrete element code for simulating progressive slope failure, coupled with a groundwater flow model that incorporates freeze/ thaw of the groundwater.

A summary of the Allegan County Bluff Stabilization Demonstration project is on the CHL Web site, http://chl.erdc.usace.army.mil/, and is updated periodically. 


\section{Current Conclusions for the Allegan Demonstration Project}

This research demonstrates tools for categorizing bluff erodibility, defining the physical subsurface of recessing bluffs, developing numerical flow models with perched water tables, and designing a dewatering system that might stabilize or retard bluff recession. Analyses conducted during the first year of dewatering (2004-2005) support the conclusions from preliminary studies: that bluffs with perched water table(s) exhibit progressive bluff failure (slumping along the face) that is triggered by a rise in piezometric levels caused by ambient freezing temperatures at the bluff face. Data analyses from the remainder of the testing period (winter 2005-summer 2007), were inconclusive because of the warmer than usual winters, and incidental well and instrument failures. In addition, the data collected during that period have not been analyzed in detail, for lack of funding since 2007. Hence, the long-term objectives of the research remain unrealized.

The Allegan Demonstration Project is designed to:

- Significantly reduce bluff movements by groundwater removal during times when the movements are traditionally the most prevalent.

- Stabilize the bluffs during times when other causative factors are in play, such as toe removal by waves.

- Show evidence that bluff movements resume at approximately their normal rates when dewatering is not conducted over significant intervals of time.

- Show that the cost of the dewatering systems is within the affordable range for governmental agencies, businesses, or homeowner groups that could benefit from a dewatering technology.

- Show that the benefit/ cost ratio will be greater for the bluff dewatering system than for conventional shore protection methods such as cement seawalls, steel sheet-pile bulkheads, and stone revetments.

- Exhibit that the dewatering installations do not detract from the aesthetic beauty or environmental quality of the installation sites or remove water that is useful in any other way. 
Current results show:

- Bluff failures are positively correlated to rises in perched groundwater levels. This relation is based on integrated pole and cable survey (slope movement) data with piezometric data. Ground movement and piezometric levels were recorded biweekly to triweekly from 1996 to November 2004 at MPS, MPN, and 116 ${ }^{\text {th }}$ Avenue, and hourly from November 2004 to September 2007.

- Rises in perched water tables and therefore soil pore pressures, are strongly correlated to freezing ambient temperatures. This relation is based on integrated piezometer data with daily air temperature data from 1996 to 2006.

- Active dewatering wells are the most effective dewatering method of deterring slope movements during times when movements are traditionally prevalent. For example, at MPS during the winter (2004-2005) movement was 400 percent greater at the control site than the dewatered site.

- Horizontal gravity drains installed into the face of the bluff were ineffective and no flow was measured from their outlets, which were frozen during the winter months. The installation of these drains did not include a filter pack around the perforated PVC; thus, these pipes probably were clogged with in situ material. However, improved installation and/ or configuration of gravity drains might be an efficient means for dewatering in selected bluff geology, specifically in bluffs with a prominent surface layer of sand atop a consistent thick clay (low permeable) layer.

- Active dewatering of the perched groundwater along the MPS site is safe. Using pumping as an alternative to conventional protection does not restrict access to the beach and slightly affects the aesthetics of the shore.

- Bluffs composed of mostly sand (greater than 66 percent sand) or mostly of clay (less than 33 percent sand) are more stable and recess at a slower rate than bluffs where alternating layers of sand and clay exist in roughly equal proportions. This conclusion is based on an aerial photographic and field-mapping study along 10 miles of Lake Michigan shoreline (Montgomery 1998; Chase et al. 1999b). Photos spanned from 1938 to 1996.

- Toe erosion by wave action is one factor in the process of bluff recession; however, it is not the major cause of long-term bluff recession. This conclusion is based on: 
o Limit equilibrium analyses of the MPS bluff that show that slumping is possible with an increase in pore pressures similar to those documented in the field, without removal of the bluff toe;

o Recent and persistent low lake-surface elevations, since 2001, and the continued slope deformation and bluff erosion observed at the three sites;

o Toe erosion from storm waves observed during the period of study to remove material from the toe of the bluff that has already been displaced from above the slope;

o Numerous bluff failures within the study area, none with evidence of being caused by toe erosion. Clearly, there are other factors influencing bluff recession besides wave action erosion.

- The current demonstration must be completed in full, to clearly determine the benefits of dewatering versus conventional systems for shoreline protection. At least three more years of dewatering and monitoring during normal winters are needed and in-depth analyses to complete the long-term objectives of the demonstration (e.g. development of optimal pumping schemes and measurement of system effectiveness, so typical costs can be calculated).

- The current groundwater numerical model is an advanced tool for examining the groundwater and pumping scheme at MPS. The model has been validated using short-term pumping tests and observation data from the field. However, funds were not available for simulating the long-term pumping (dewatering) periods; therefore, the objective for developing an optimal pumping scheme was not accomplished. It appears that more pumps with smaller flow rates would be better suited for the MPS site. A long-term simulation of the dewatering data would allow refinement and further development of the numerical model such that alternative pumping schemes could be simulated and compared. In addition, efficiency of gravity drains could be compared to pumping well efficiency, at sites where either method is applicable.

- An inconsistency between the resistivity and soil temperature data (CRREL) and the depth of frozen soil observed in the field. These instruments were either too deep or protected to measure freezing water, or temperatures. If the demonstration continues, manual digging will be performed adjacent to these instruments for validation. In addition, other instruments for measuring frozen groundwater will be explored. 
Current results have not shown:

- That dewatering can stabilize the bluff when storm waves are actively eroding the backshore or bluff toe. This demonstration was conducted when lake levels were low.

- That dewatering is affordable or has long-term effectiveness. The dewatering was conducted during warm winters (excluding 2004). Thus this demonstration has not shown conclusively that dewatering deters slope movement over many years or that slope movement resumes when dewatering is stopped. Multiple years of dewatering are necessary to test whether the slope stabilization effects are reproducible and whether statistical treatments of the data are valid under a variety of weather conditions. 


\section{Recommendations}

Bluff dewatering as a long-term mitigation strategy for coastal bluff stabilization has not been scientifically demonstrated. The data set needed to evaluate dewatering strategies through statistical treatments such as regression analyses, correlation coefficients, and error analysis will not be fully available until the dewatering phase of the project has run through the entire five-year cycle. It is strongly recommended that this project be continued in light of the unusually large volume of high-quality data collected and the large investments made to design, construct, operate, and suspend the project. Approximately $\$ 4.7$ million has been spent for the Allegan Bluff Stabilization Demonstration project. It is estimated that $\$ 420,000$ will complete the project.

Based on data trends observed before the shutdown, the dewatering project will prove with statistical validity that removal of groundwater during winter/spring freeze/ thaw cycles in northern climates will significantly slow or stop mass movements where glacial soils are weakened by surface freezing and the buildup and release of groundwater pore pressure. Project data from 2001 to 2007 have been archived for future analyses. At minimum, the demonstration must continue for another two years of winter dewatering to achieve the project's original objective. Another year will be required for data analysis and report publications.

Recommended additional research includes extensive use of the hourly readings to simulate a full year of groundwater flow for the purpose of validating the current groundwater model. The groundwater model makes it possible to optimize a dewatering system (e.g., a horizontal gravity drain system or a vertical pumping system), making it possible to determine if dewatering is economical. Much insight could be gained from a complete review of the field data, using the model as an analysis tool.

The hourly readings collected from 2004 through 2007 provide a rare opportunity to conduct advanced research and development in slope stability and numerical modeling. Proposed advanced research would include coupling the groundwater model with a large deformation model and a heat transport model. The enhanced numerical model would not rely on a defined failure mechanism, such as a limit equilibrium model, but 
would simulate a realistic failure. The model would be capable of simulating the actual deformation of the bluffs (formation of slumps) with the changes in groundwater levels and temperature. Proposed numerical techniques include development of a discrete element code to simulate progressive slope failure, coupled with a groundwater flow model that incorporates freezing and thawing of groundwater.

There is much to be gained by continuing this study. It is an opportunity to see inside a moving slope by measuring the dynamic factors affecting its stability. The benefits of continuing this demonstration include advanced characterization of bluff failure mechanisms and development of an efficient, economic and aesthetic alternative to conventional shore protection systems. By understanding the interactions of groundwater freeze/ thaw cycles with bluff geology and stability, we can define the conditions that trigger failure. The ultimate goal then can be realized: to prevent the loss of life and property by developing effective and economical technologies that prevent bluff failure. 


\section{References}

Andrews, E. 1870. The North American Lakes considered as chronometers of post-glacial time. Trans. Chicago Acad. Sci. II (1870):1-24.

Buckler, W. R. 1987. High water levels and bluff recession, Lake Michigan's southeast shore. The East Lakes Geographer 22:157-177.

Buckler, W. R., and H. A. Winters. 1983. Lake Michigan Bluff recession. Annals of the Association of American Geographers 73:89-110.

Chamberlin, T. C. 1877. Geology of Wisconsin, survey of 1873-1877. Commissioners of Public Printing, WI. http://digital.library.wisc.edu/1711.dl/EconatRes.Vo2.

Chase, R. B. 1990. A structural analysis of fractures in clay-rich tills of southwestern Michigan. Kalamazoo, MI: Department of Geology, Western Michigan University.

Chase, R. B., A. E. Kehew, and W. W. Montgomery. 1999a. Mechanisms and causes of mass movements in heterogeneous glacial materials: Examples from the southeastern Lake Michigan shoreline bluffs. In International Association of Great Lakes Research, 42nd Conference Program, A-17- A-18.

Chase, R. B., A. E. Kehew, and W. W. Montgomery. 1999b. The destabilizing influences of perched ground water in shoreline bluffs composed of heterogeneous glacial materials. Geological Society of America Abstracts with Programs 31.

Chase, R. B., K. E. Chase, A. E. Kehew, and W. W. Montgomery. 2001a. Determining the kinematics of slope movements using low-cost monitoring and cross-section balancing. Environmental and Engineering Geoscience VII(2):193-203.

Chase, R. B., A. E. Kehew, and W. W. Montgomery. 2001b. Determination of slope displacement mechanisms and causes: An approach using new geometric modeling techniques and climate data. In Landscape erosion and evolution modeling, eds. R. S. Harmon and W. W. Doe III, 57-87. New York: Kluwer Academic/ Plenum Publishers.

Chase, R. B. 2003. Personal communication, Miami Park South April 12, 2001, displacement cross section, interpreted by Ron Chase, unpublished personal notes.

Chase, R. B. 2005. Mitigation of Slope Failures in Great Lakes Glacial Environments by Removal of Groundwater, Progress-Report Presentation to USACE-ERDC, Vicksburg, MS.

Chase, R. B., A. E. Kehew, M. E. Glynn, and J . P. Selegean. 2007a. Modeling debris slide geometry with balanced cross-sections: A rigorous field test. Environmental and Engineering Geoscience XIII(1):45-53. 
Chase, R. B., A. E. Kehew, R. B. Kaunda, and M. E. Glynn. 2007b. Mitigation of slope failures in a freeze/ thaw environment by removal of ground water. In 1st North American Landslide Conference. Association of Engineering Geologists Special Publication 23:1582-1594.

Davis, R. A. 1976. Coastal changes, eastern Lake Michigan, 1970-73. Technical Paper 76-16. Fort Belvoir, VA: U.S. Army Engineer Coastal Engineering Research Center.

Davis, R. A., W. G. Fingleton, and P. C. Pritchett. 1975. Beach profile changes: East coast of Lake Michigan, 1970-1972. Miscellaneous Paper 10-75. Fort Belvoir, VA: U.S. Army Engineer Coastal Engineering Research Center.

Edil, T. B., and L. E. Vellejo. 1980. Mechanics of coastal landslides and the influence of slope parameters. In Mechanics of landslides and slope stability, ed. S. L. Koh. Engineering Geology 16:83-96.

Edris, E. V., and S. G. Wright. 1992. Users guide: Utexas 3 slope stability package; IV: User's manual. Instruction Report GL-87-1. Vicksburg, MS: U.S. Army Engineer Waterways Experiment Station.

Ferrand, W. R., and D. L. Bell. 1982. Quarternary geology of Southern Michigan. University of Michigan Ann Arbor.

Ferrick, M. G., L. W. Gatto, and C. R. Williams. 2005. Cold regions data acquisition and analysis for Section 227 National Shoreline Erosion Control Development and Demonstration Program - Miami Park South, Allegan County, Michigan. ERDC/CRREL TN-05-6. Hanover, NH: U.S. Army Engineer Cold Regions Research and Engineering Laboratory.

Hansen, P. H., S. E. Howington, and M. E. Glynn. 2007. Flow model study for section 227 demonstration project in Allegan County, Michigan. ERDC TR-07-12. Vicksburg, MS: U.S. Army Engineer Research and Development Center.

Kamphuis, J. W. 1987. Recession rate of glacial till bluffs. J ournal of Waterway, Port, Coastal, and Ocean Engineering, ASCE 113:60-73.

Kaunda, R. B. 2007. Some applications of Gaussian quadrature and neural network modeling in earth flows and other slow-moving landslides in cohesive slope materials. PhD diss., Western Michigan Univ.

Keillor, J . P. 2002. Living on the coast, protecting investments in shore property on the Great Lakes. U.S. Army Corps of Engineers Detroit District, Detroit, MI. and University of Wisconsin-Madison, Sea Grant.

Monaghan, G. W., G. J . Larson, and G. D. Gephart. 1986. Late Wisconsonian drift stratigraphy of the Lake Michigan lobe in southwestern Michigan. Geological Society of America Bulletin 97:329-334.

Montgomery, W. W. 1998. Groundwater hydraulics and slope stability analysis; Elements for prediction of shoreline recession. PhD diss., Department of Geology, Western Michigan Univ. 
Powers, W. E. 1958. Geomorphology of the Lake Michigan shoreline. Arlington, VA: Office of Naval Research. AD No. AD160064.

Raphael, C. N. and E. J . C. Kureth, and Eastern Michigan University. 1998. Bluff line recession and economic loss in coastal Berrien County, Michigan. Institute for Community and Regional Development, Eastern Michigan University, Ypsilanti, MI.

Roctest. 2008. Vibrating Wire Piezometers PW Series. http:// www.roctest.com/modules/.

Ross, P. 2005. Personal communication. Project manager, Sheboygan, WI, stabilization project. USACE, Detroit District.

Seibel, E. A. 1972. Shore erosion at selected sites on Lake Michigan and Lake Huron. $\mathrm{PhD}$ diss., Department of Oceanography, Univ. of Michigan.

Sterrett, R. J ., and T. B. Edil. 1982. Ground water flow systems and stability of a slope. Groundwater 20(1):5-11.

STS Consultants, LTD. M. Emrick and J . Matus. 2003. Geotechnical investigation, bluff stabilization demonstration project - Allegan County, Michigan. STS Consultants, LTD., Lansing, MI.STS Project No. 74067, March 11, 2003.

STS Consultants, LTD. M. Emrick and J . Matus. 2005. Geotechnical investigation bluff stabilization demonstration project, Allegan County Michigan: prepared for U.S. Army Corps - Detroit District, Delivery Order No. 0011, Contract No. DACW 3502-D-002 STS Project No. 7-74257A.

Slope Indicator. 2008. EL In-Place Inclinometer Sensors, Inclinometer Manuals. http:// www.slopeindicator.com/instruments/inclin-intro.html.

USACE, Detroit District. 2008. Great Lakes water levels, current conditions, water level forecasts and historic data. U.S. Army Corps of Engineers, Detroit District, http://www.Ire.usace.army.mil/greatlakes/hh/greatlakeswaterlevels/.

Woodward, N. B., S. E. Boyer, and J. Suppe. 1985. An outline of balanced cross-sections. Knoxville, TN: University of Tennessee Publication. 


\section{Appendix A: Detailed Geologic Logs for Rotosonic Drill Holes ALG-02-01 (MPS), ALG- 02-02 (116 th Avenue), and ALG-02-03 (MPN)}




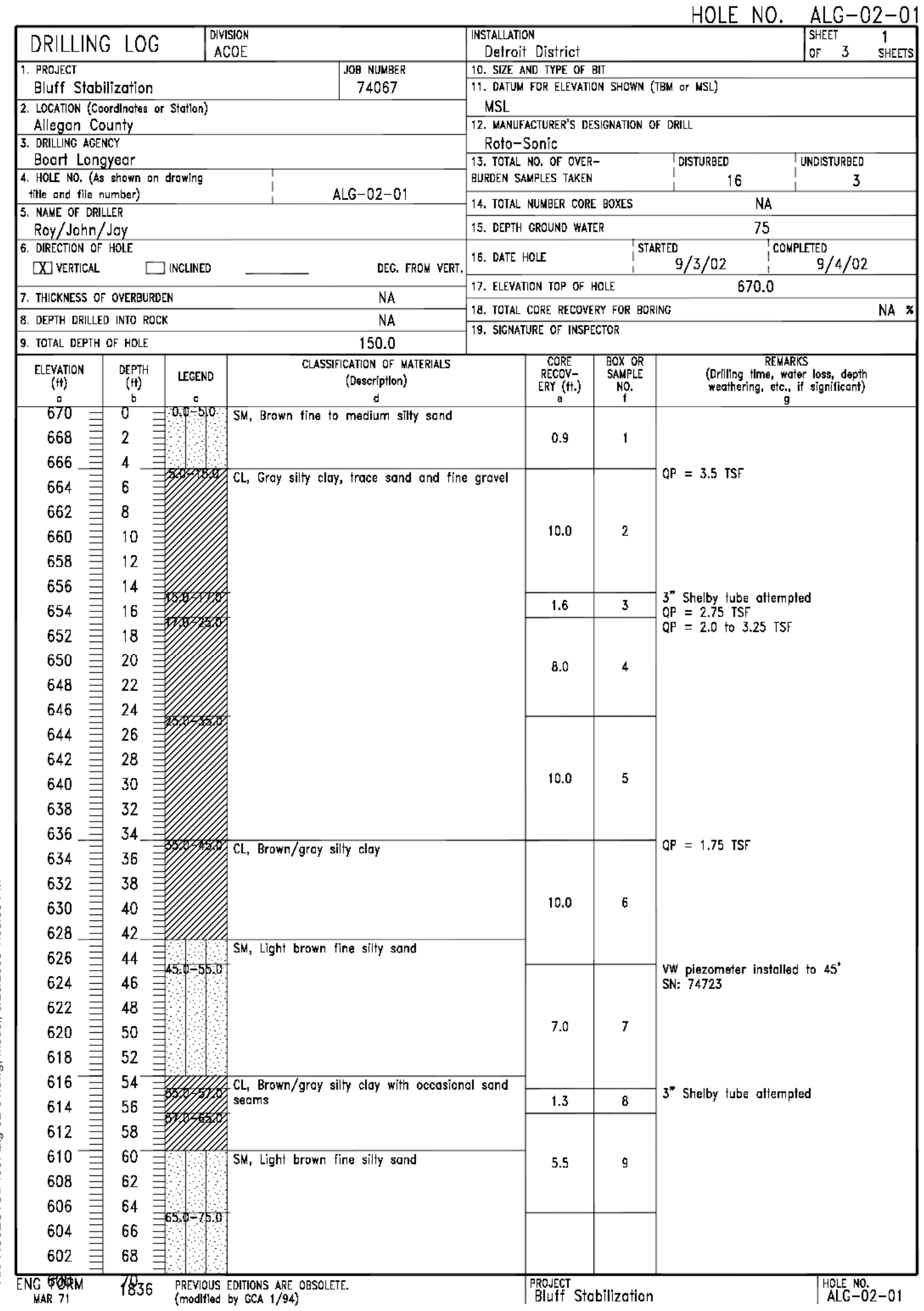




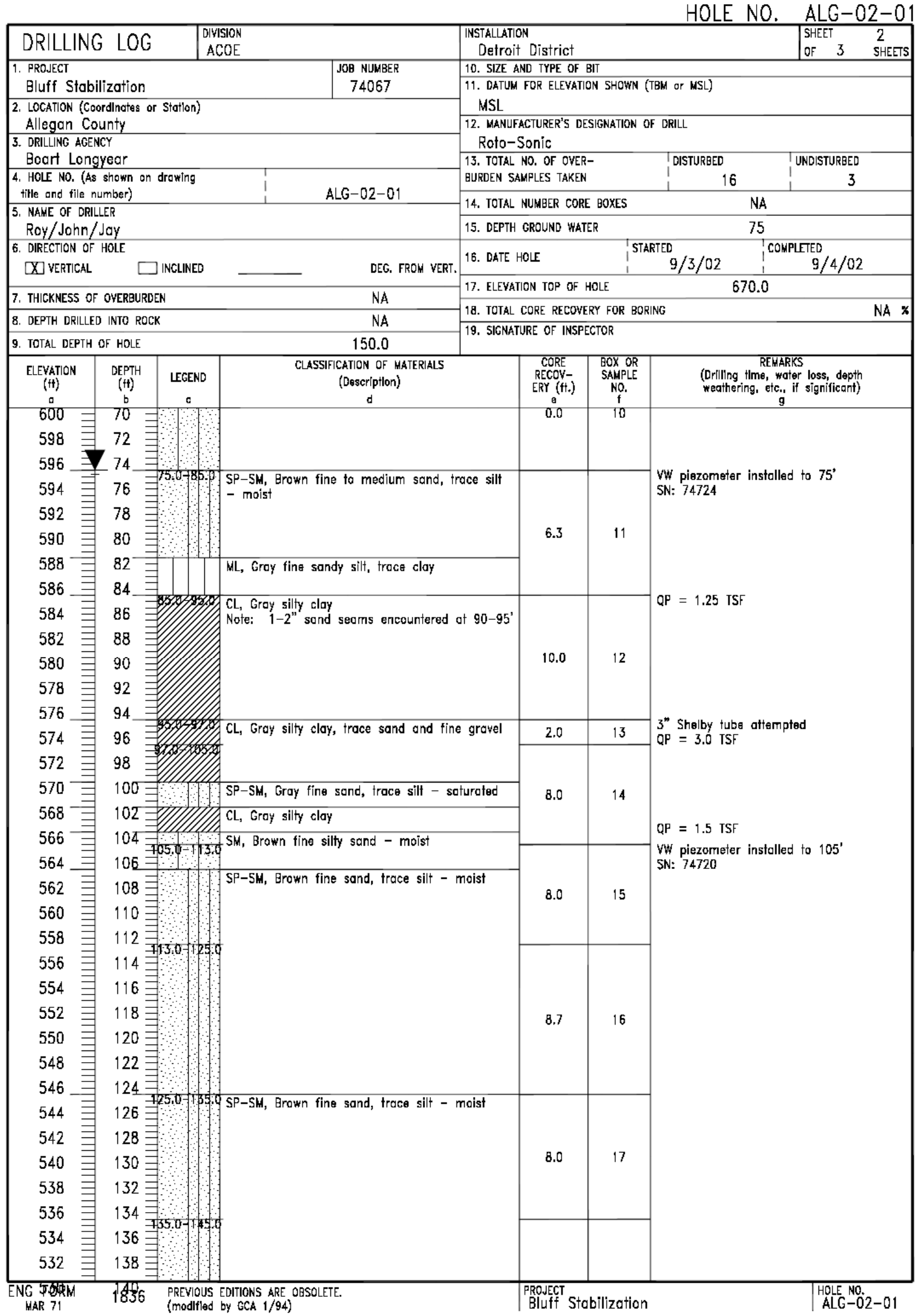




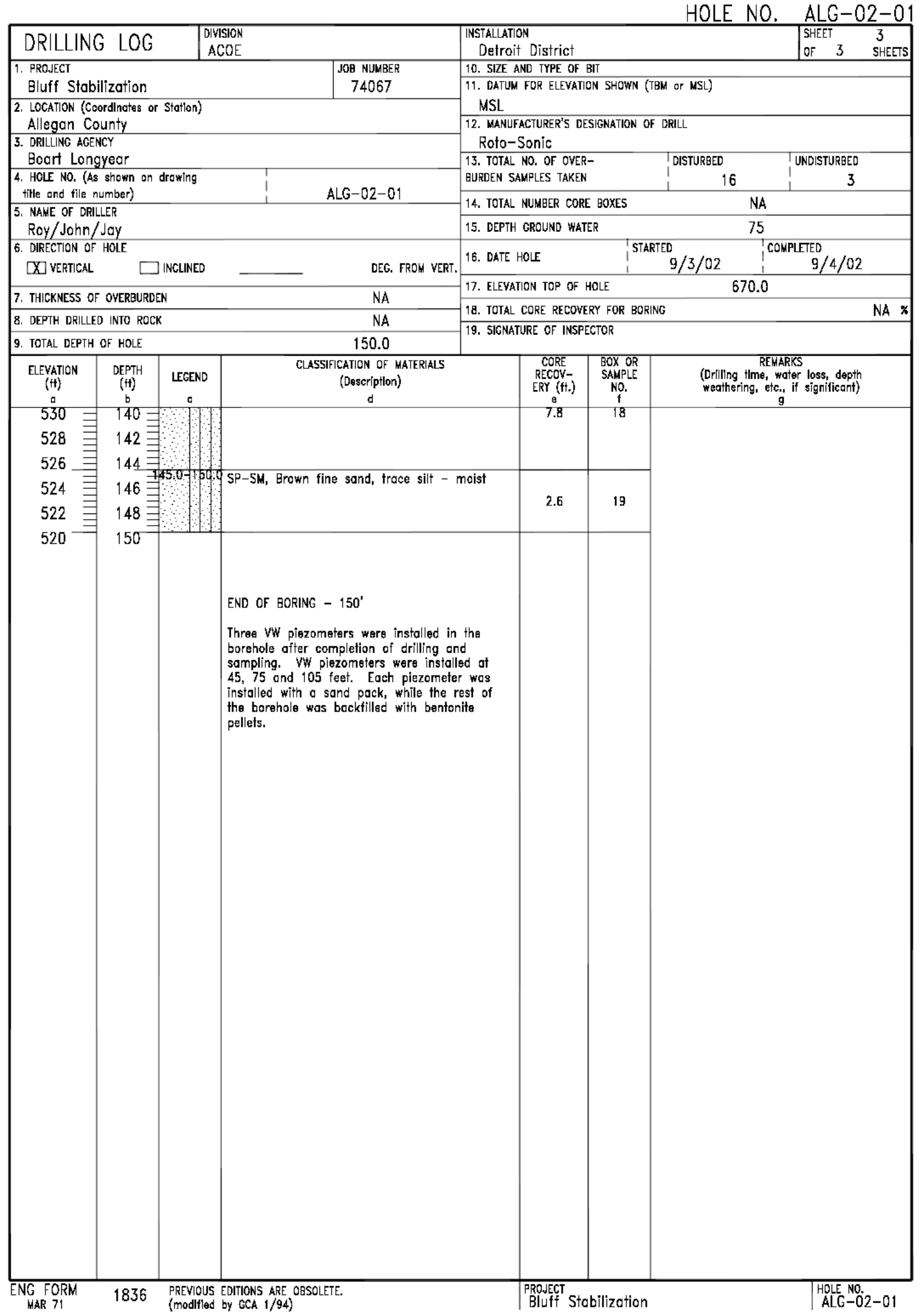




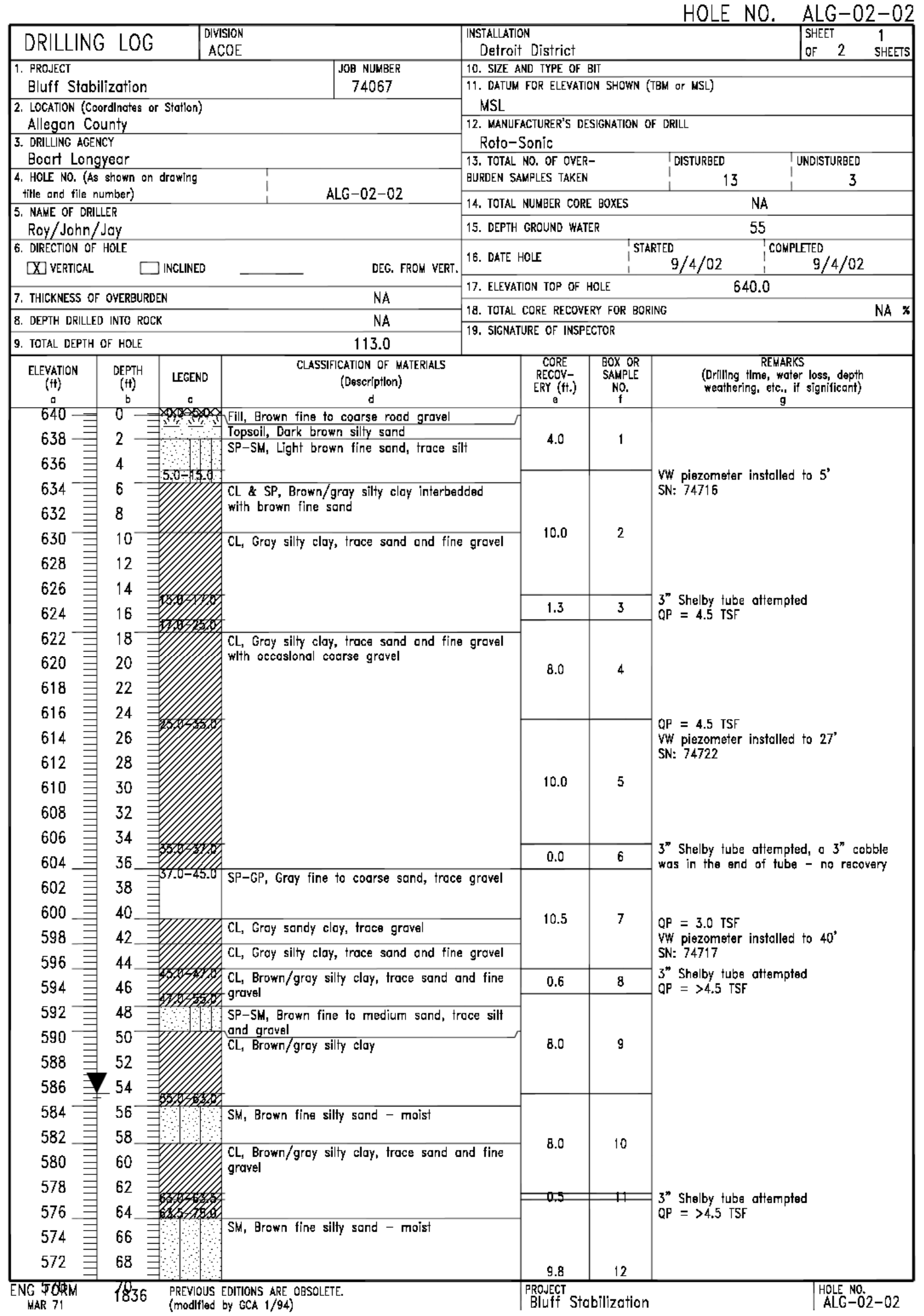




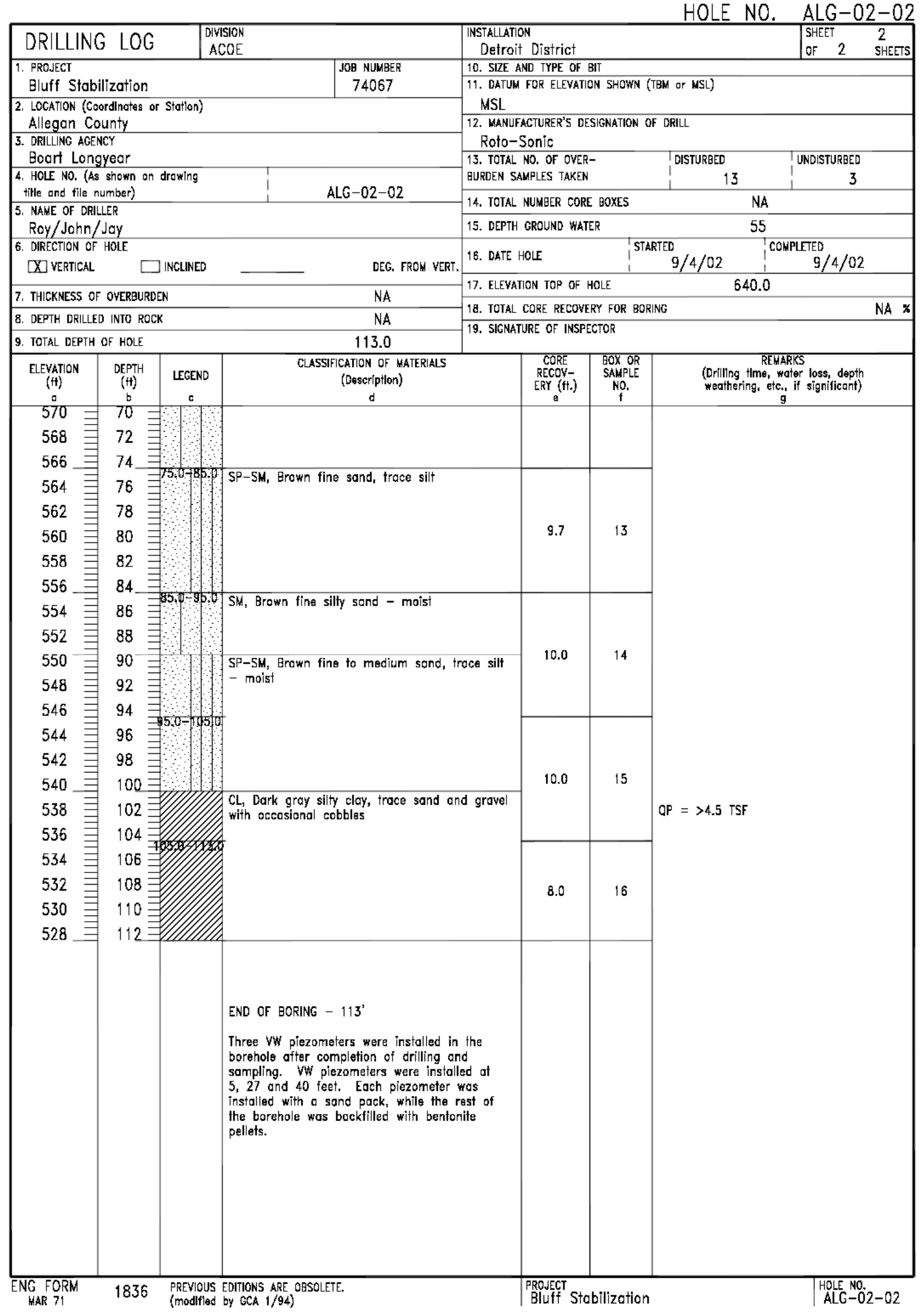




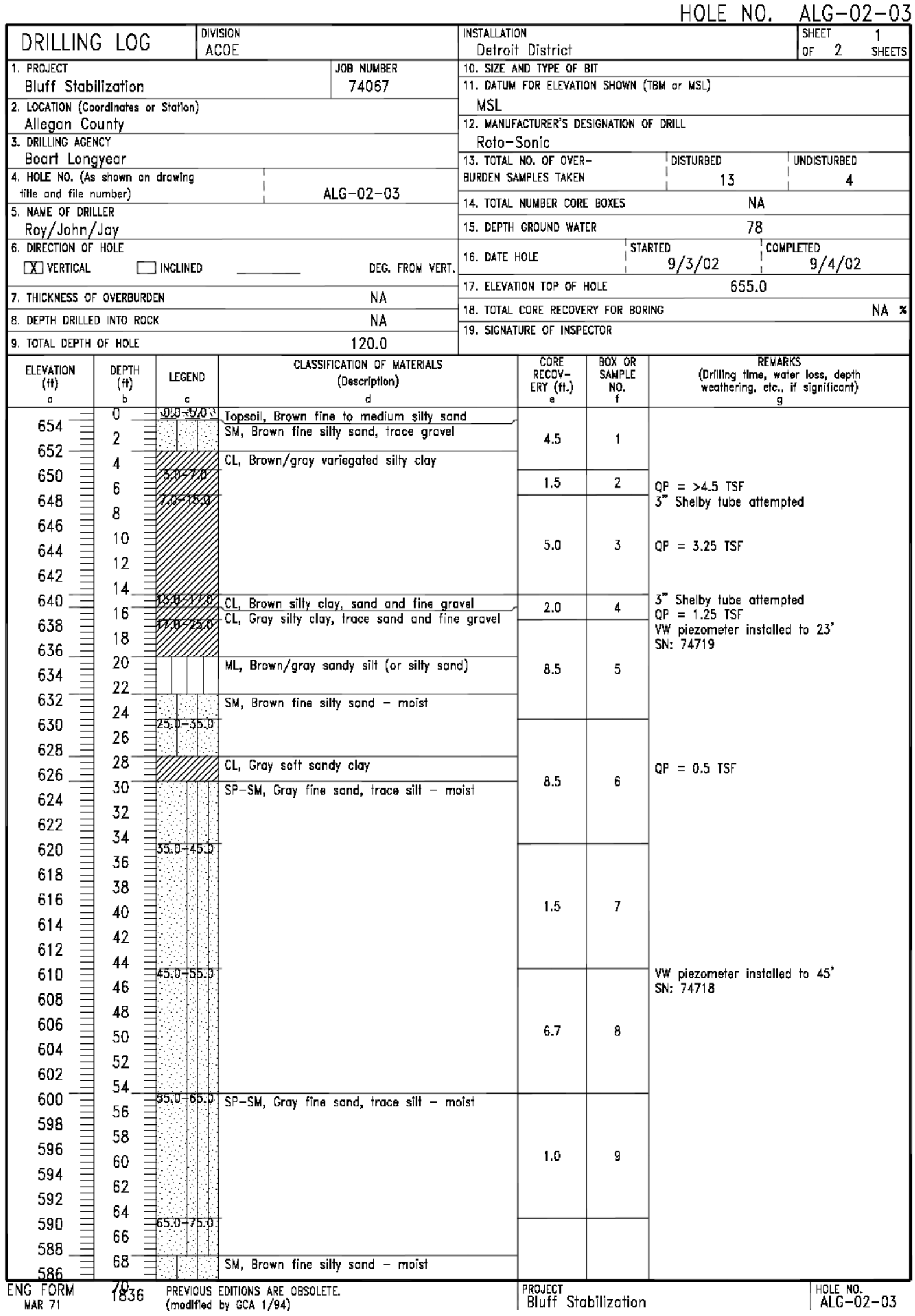




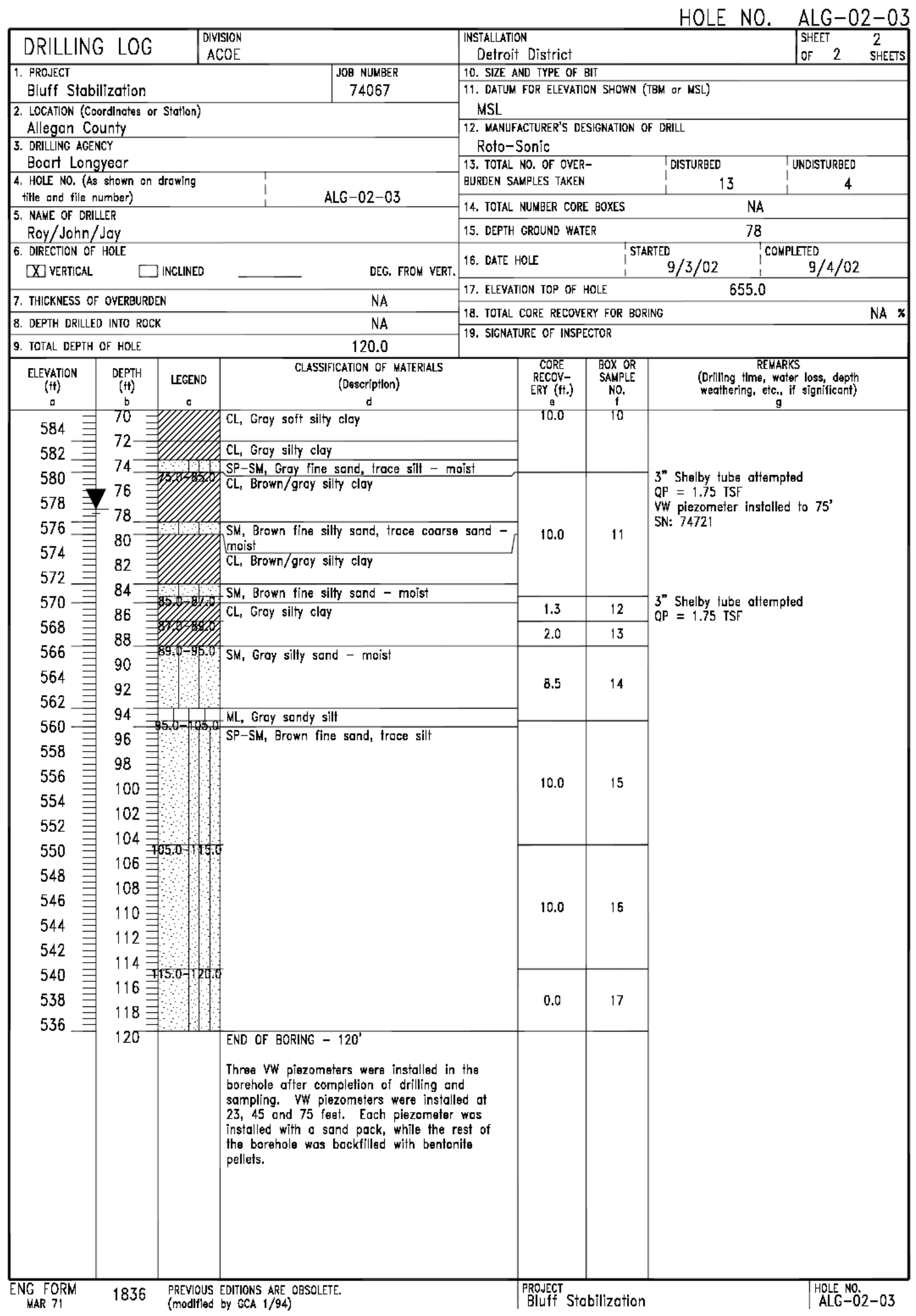




\section{Appendix B: Summary of STS Laboratory Testing (2003) for Rotosonic Drill Holes and Vibrating Wire Piezometer Installation Details}




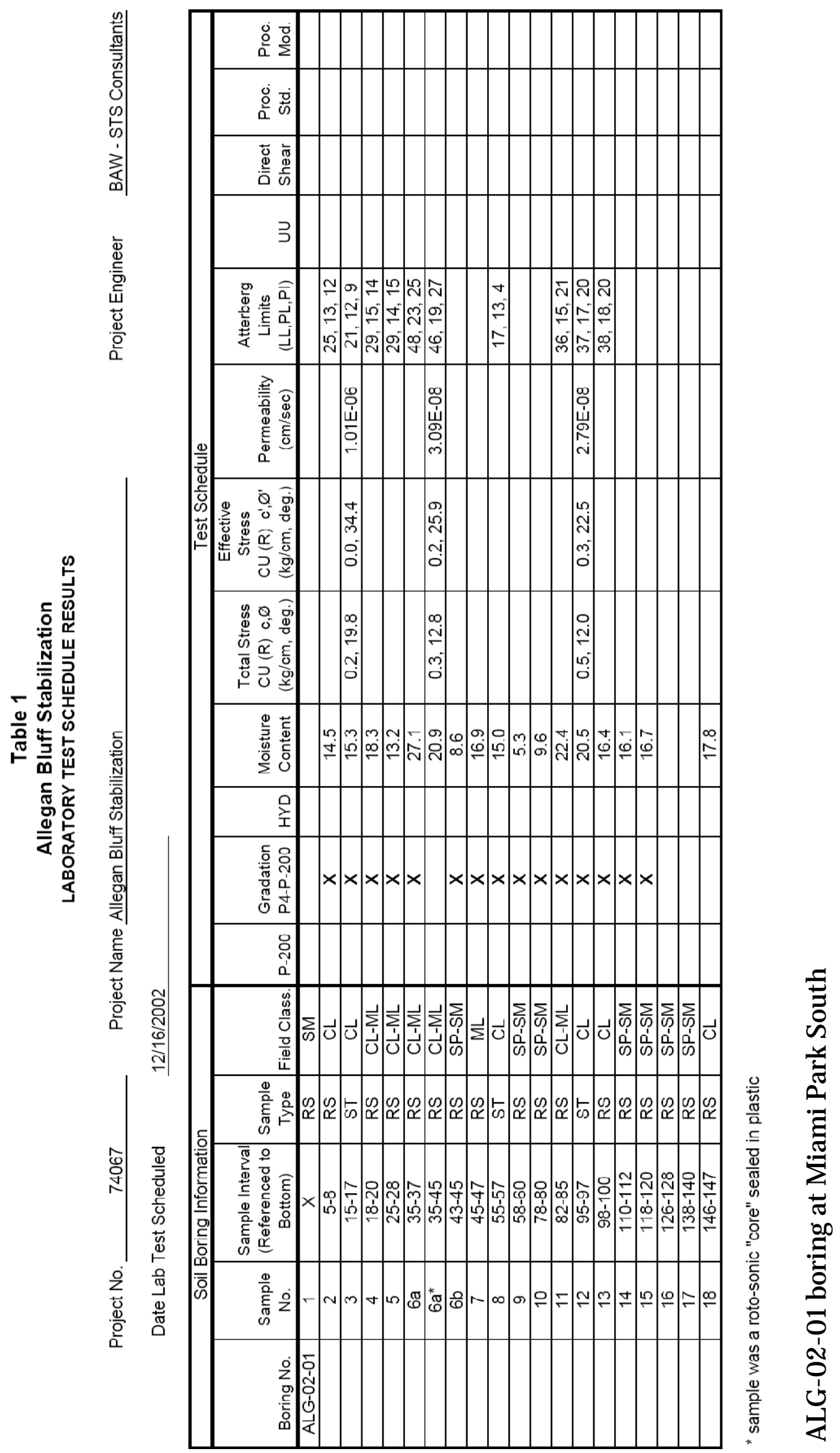




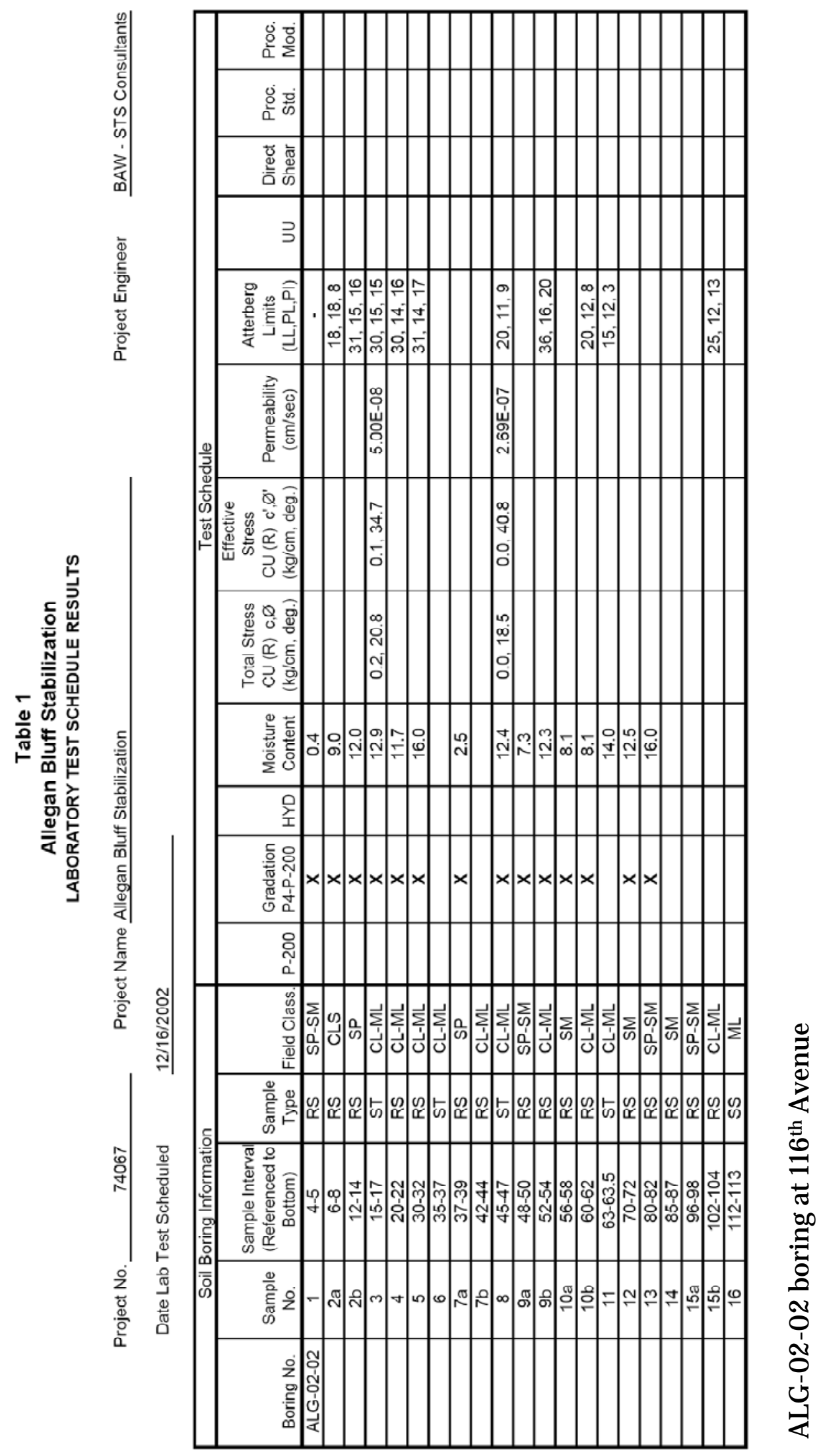




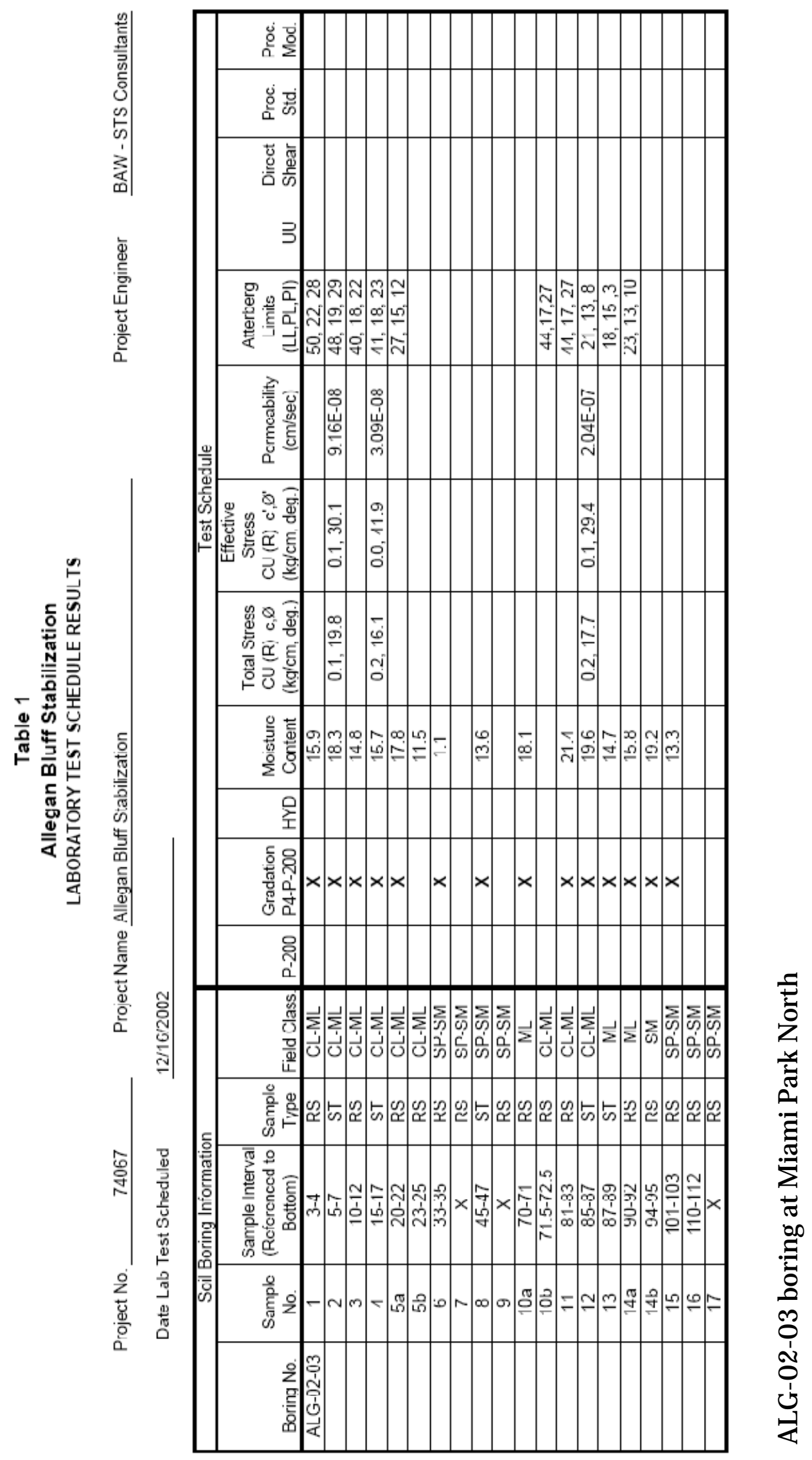




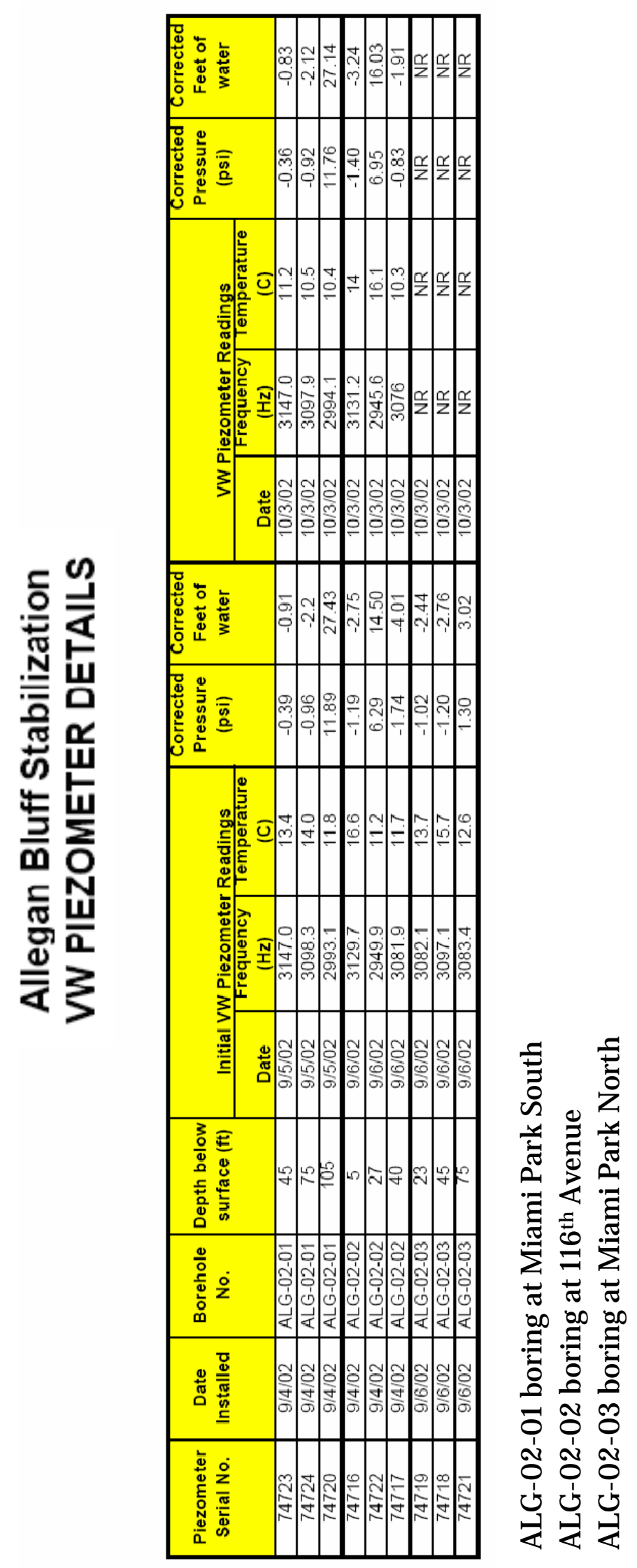




\section{Appendix C: STS Laboratory Test Results (2005) - Samples from Instrumentation Borings}

In this appendix are CU triaxial compression, particle size distribution, hydraulic conductivity, specific gravity, and permeability test details. 


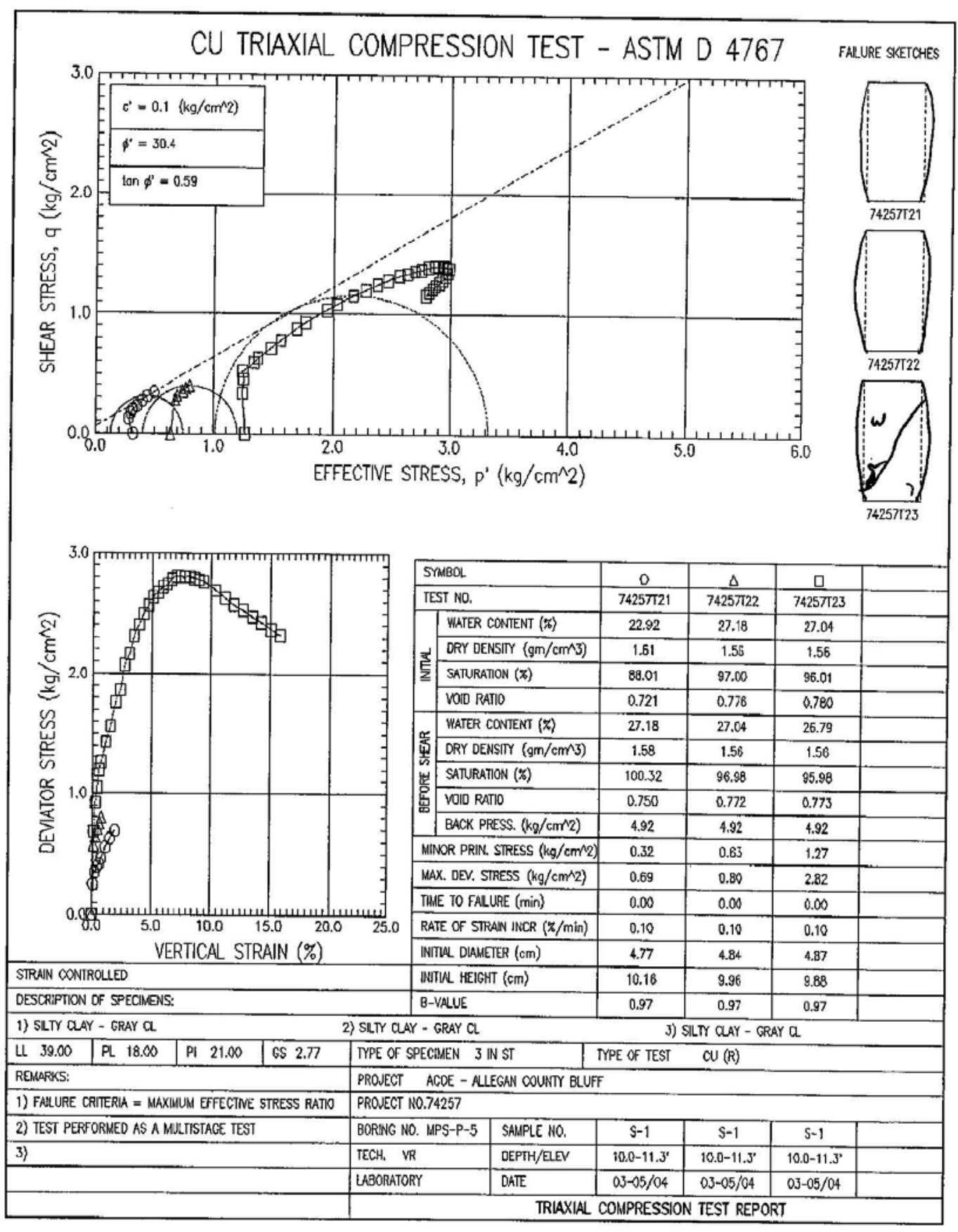




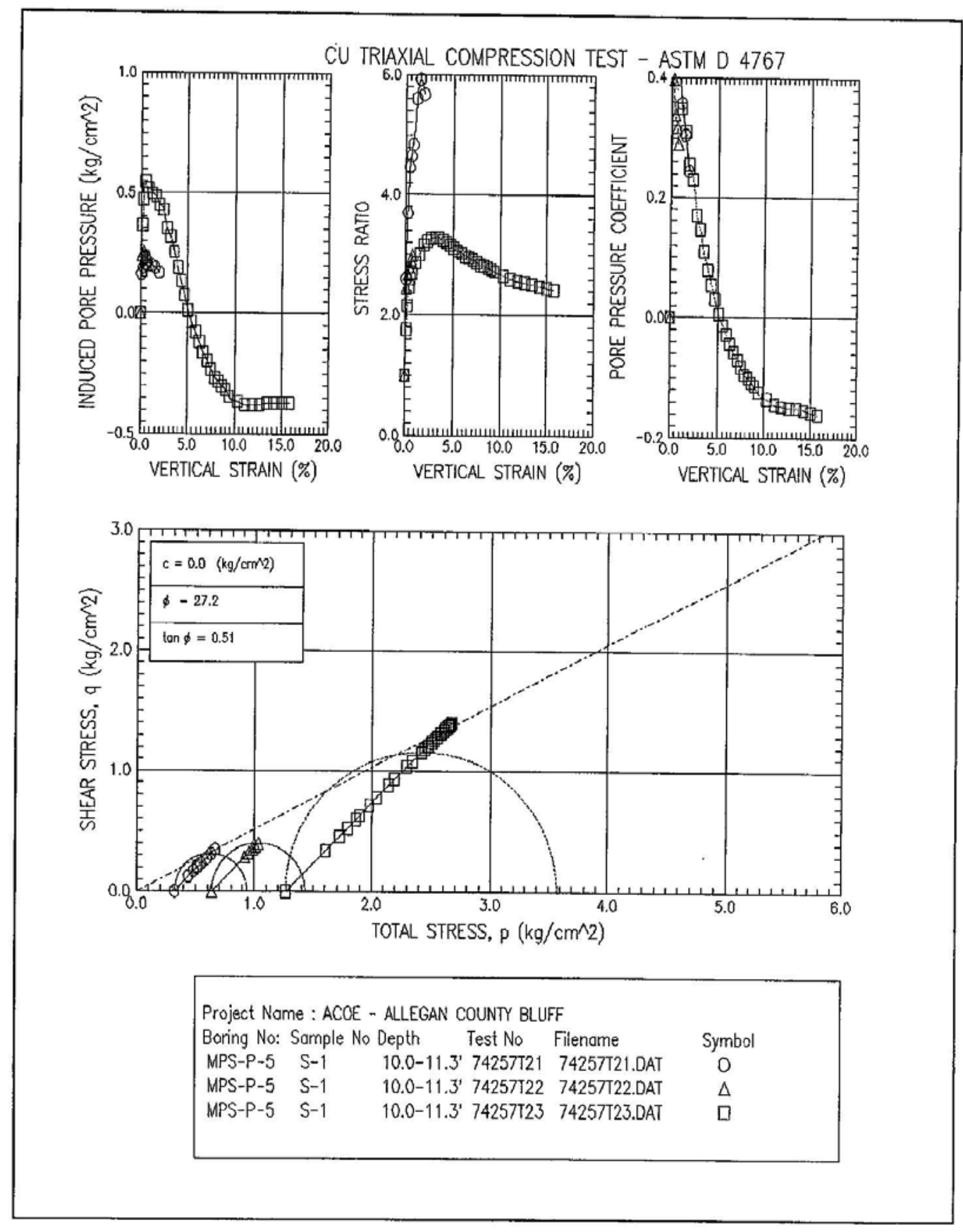




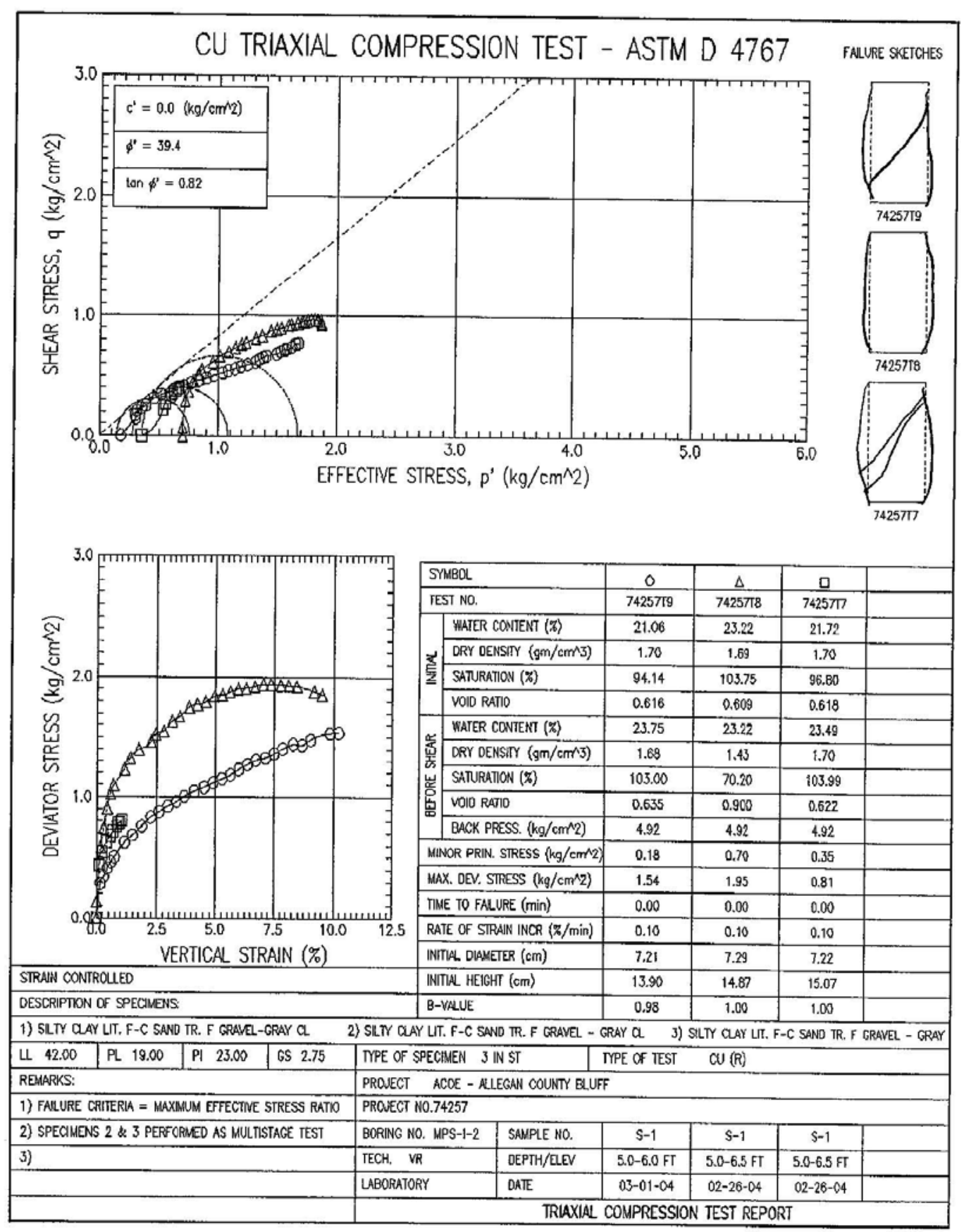




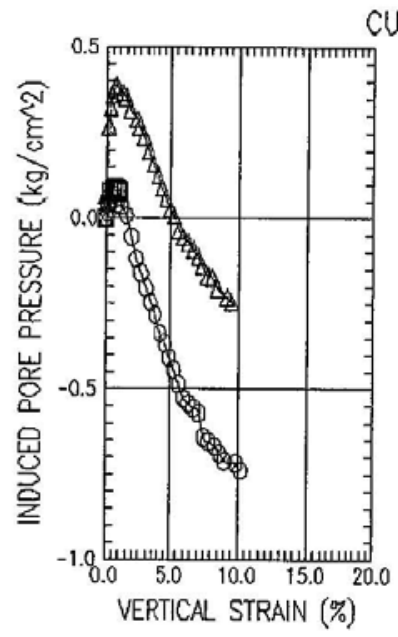

CU TRIAXIAL COMPRESSION TEST - ASTM D 4767

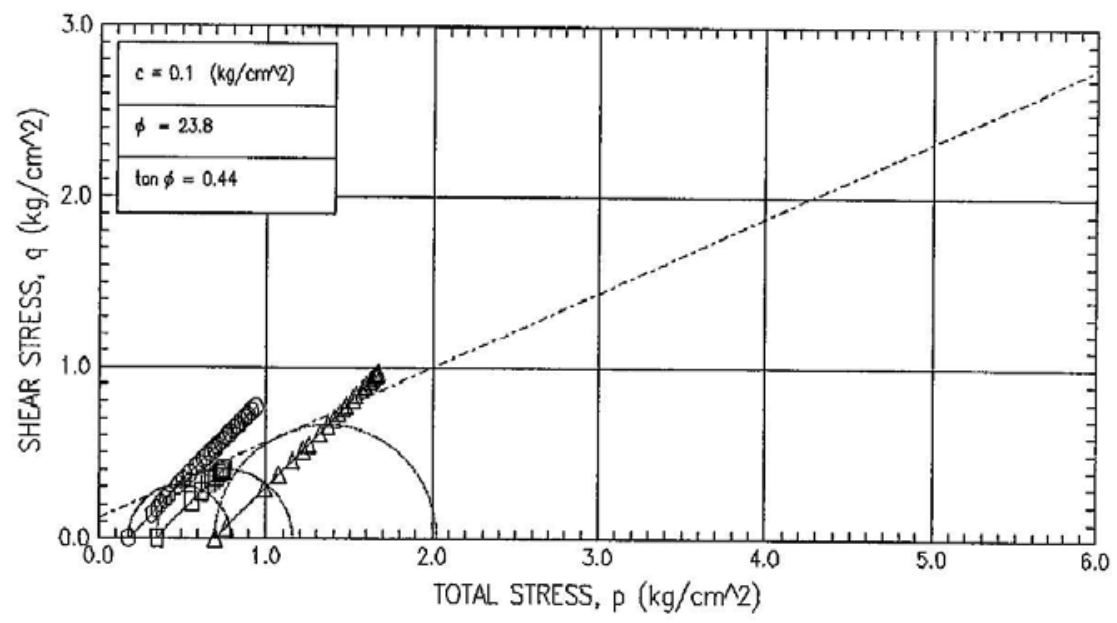

Project Narne : ACOE - ALLLEGAN COUNTY BLUFF

Boring No: Sample No Depth Test No Filename

MPS-1-2 S-1 5.0-6.0 FT 74257T9 74257T9.DAT

$\begin{array}{llll}\text { MPS- } 1-2 & \text { S- } 1 \quad 5.0-6.5 \text { FT } 7425778 & \text { 74257T8.DAT }\end{array}$

MPS-1-2 S-1 5.0-6.5 FT 74257T7 74257T7.DAT

Symbol

0

$\Delta$ 


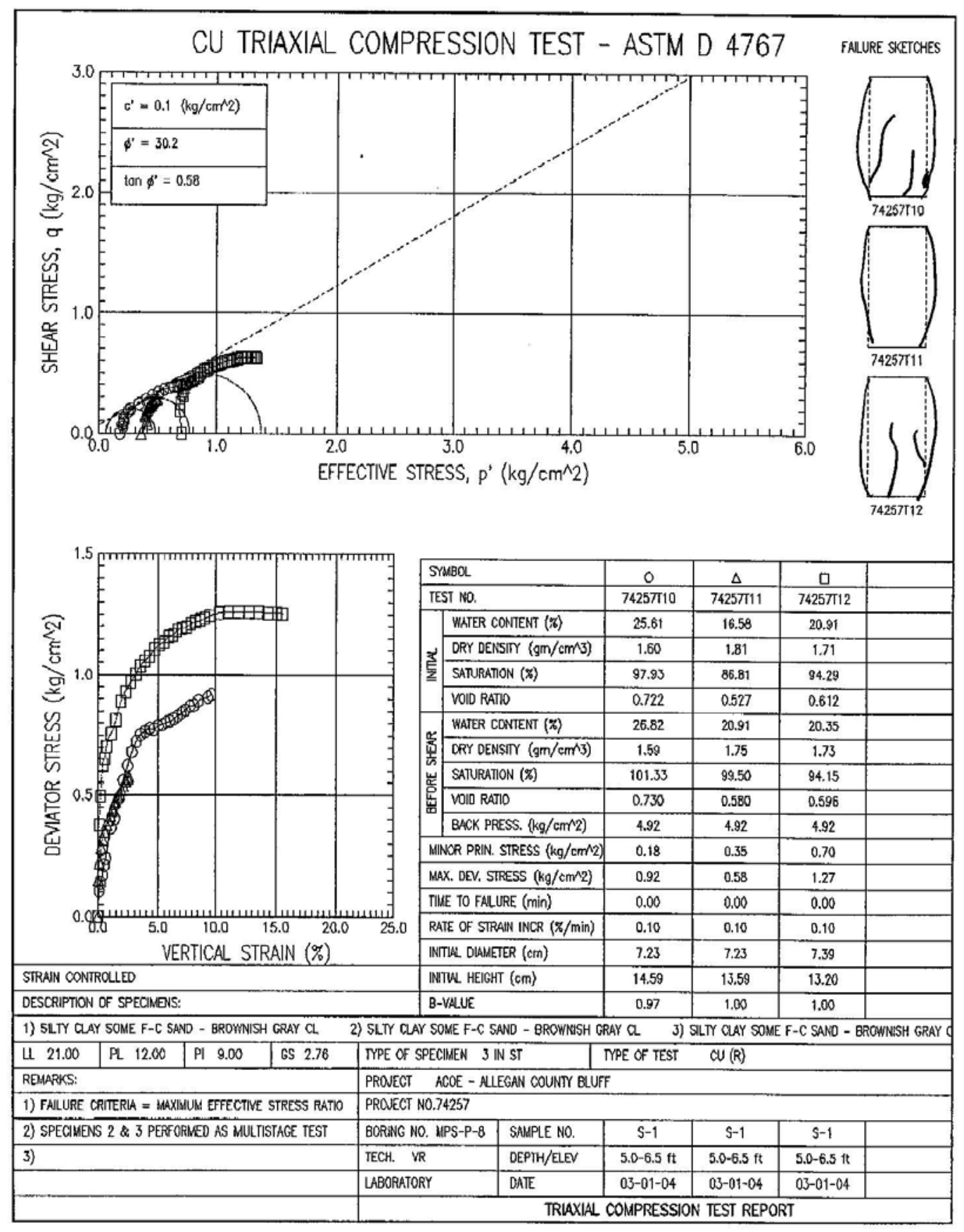




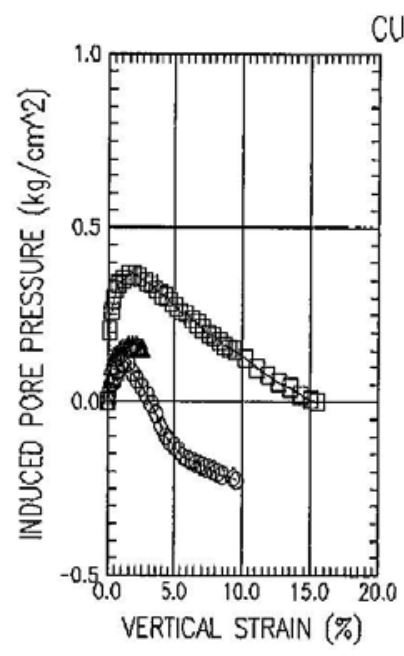

CU TRIAXIAL COMPRESSION TEST - ASTM D 4767
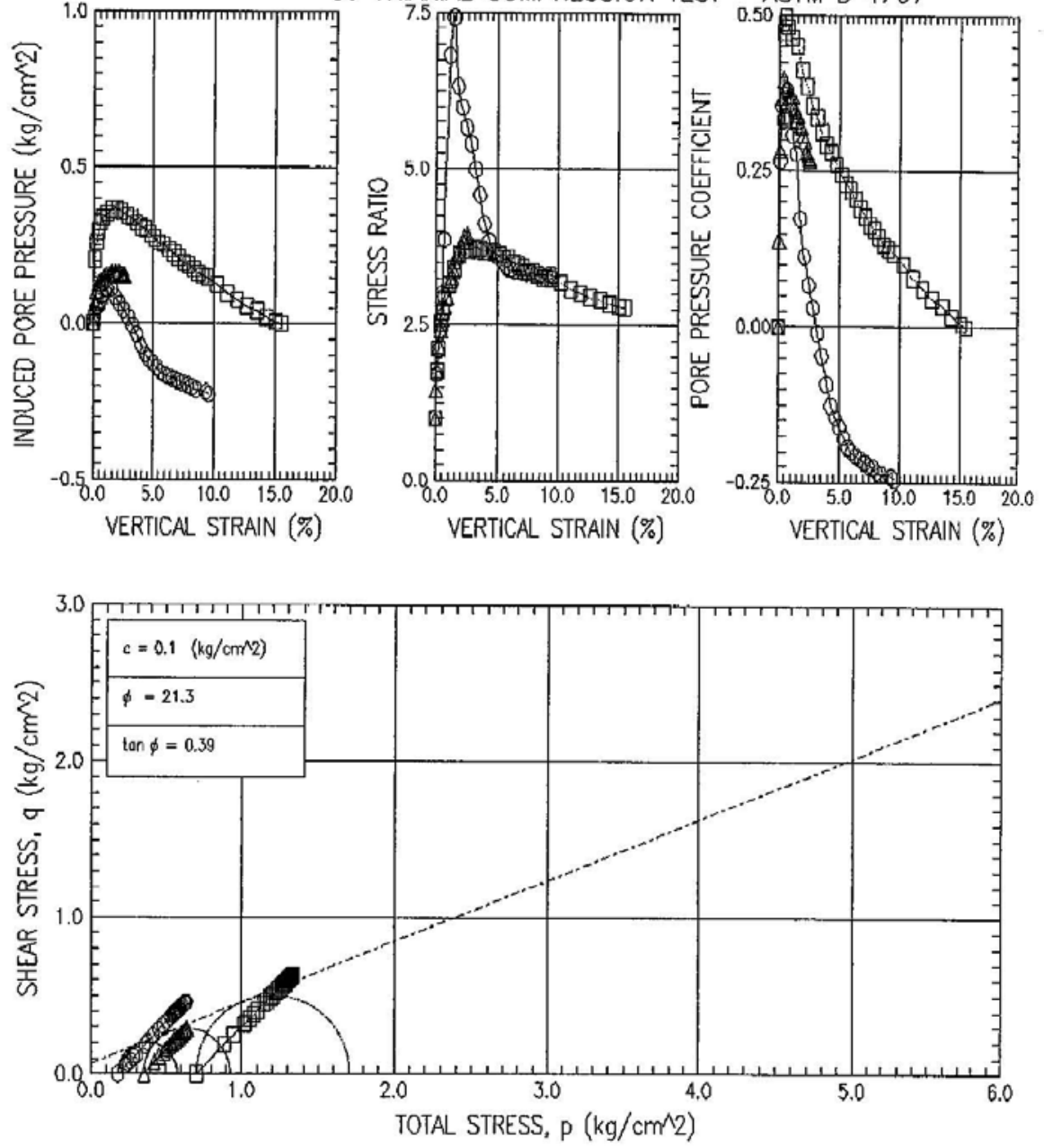

Project Name : ACOE - ALLEGAN COUNTY BLUFF

$\begin{array}{llllll}\text { Boring No: } \text { Sample No Depth } & \text { Test No } & \text { Filename } & \text { Symbol } \\ \text { MPS-P-8 } & S-1 & 5.0-6.5 \mathrm{ft} & 74257 \mathrm{~T} 10 & 74257 \mathrm{~T} 10.0 \mathrm{AT} & \mathrm{O}\end{array}$

$\begin{array}{lllll}\text { MPS-P-8 } & S-1 \quad 5.0-6.5 \mathrm{ft} \quad 74257710 \quad 74257710.0 A T\end{array}$

$\begin{array}{llllll}\text { MPS-P-8 } & \text { S- } 1 \quad 5.0-6.5 \mathrm{ft} & 74257711 & 74257111 . D A T\end{array}$

$\begin{array}{lllll}\text { MPS-P-8 S-1 } & 5.0-6.5 \mathrm{ft} & 74257 T 12 & 74257 T 12 . D A T\end{array}$

$\Delta$ 


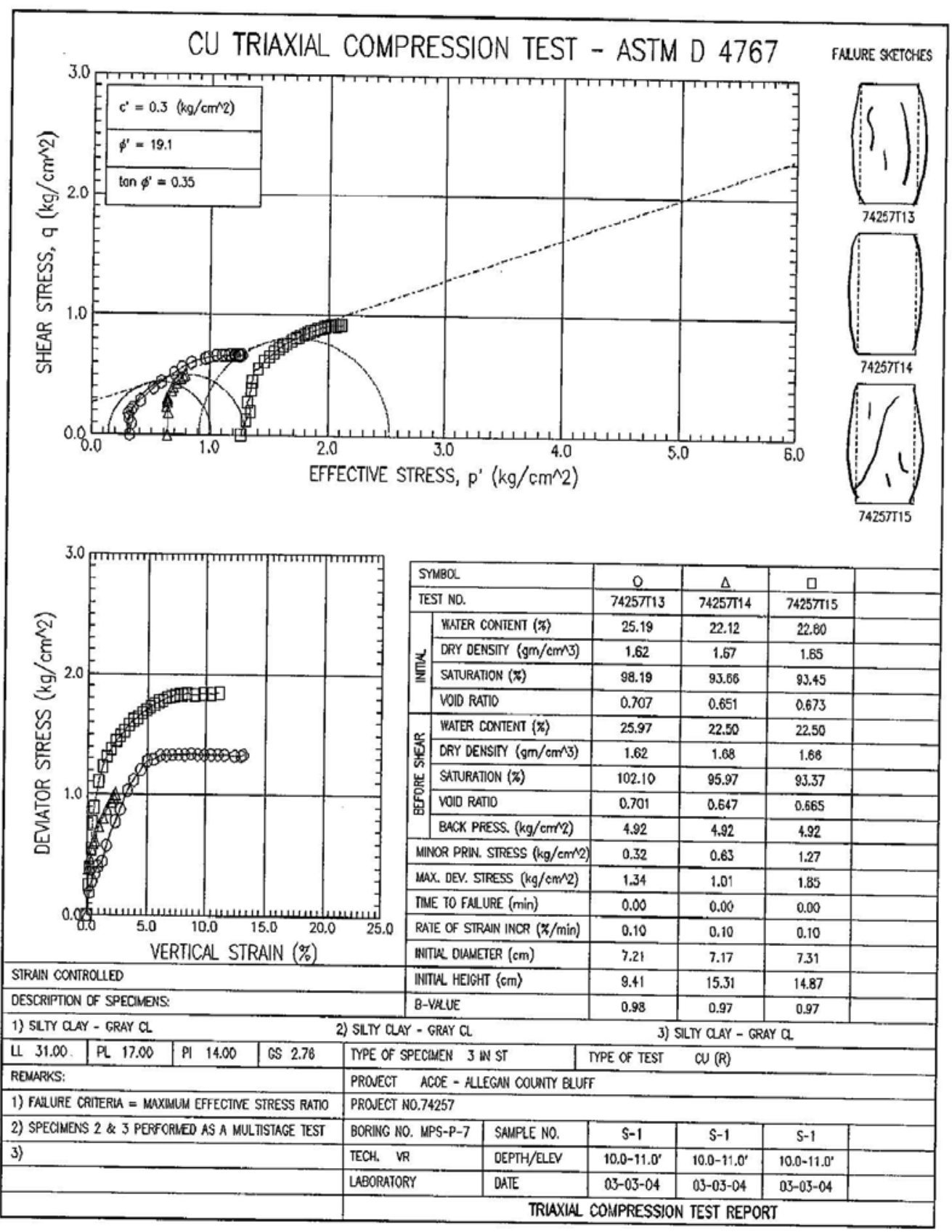




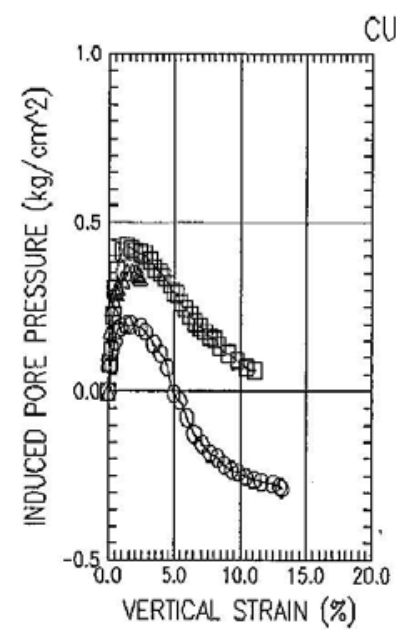

CU TRIAXIAL COMPRESSION TEST - ASTM D 4767
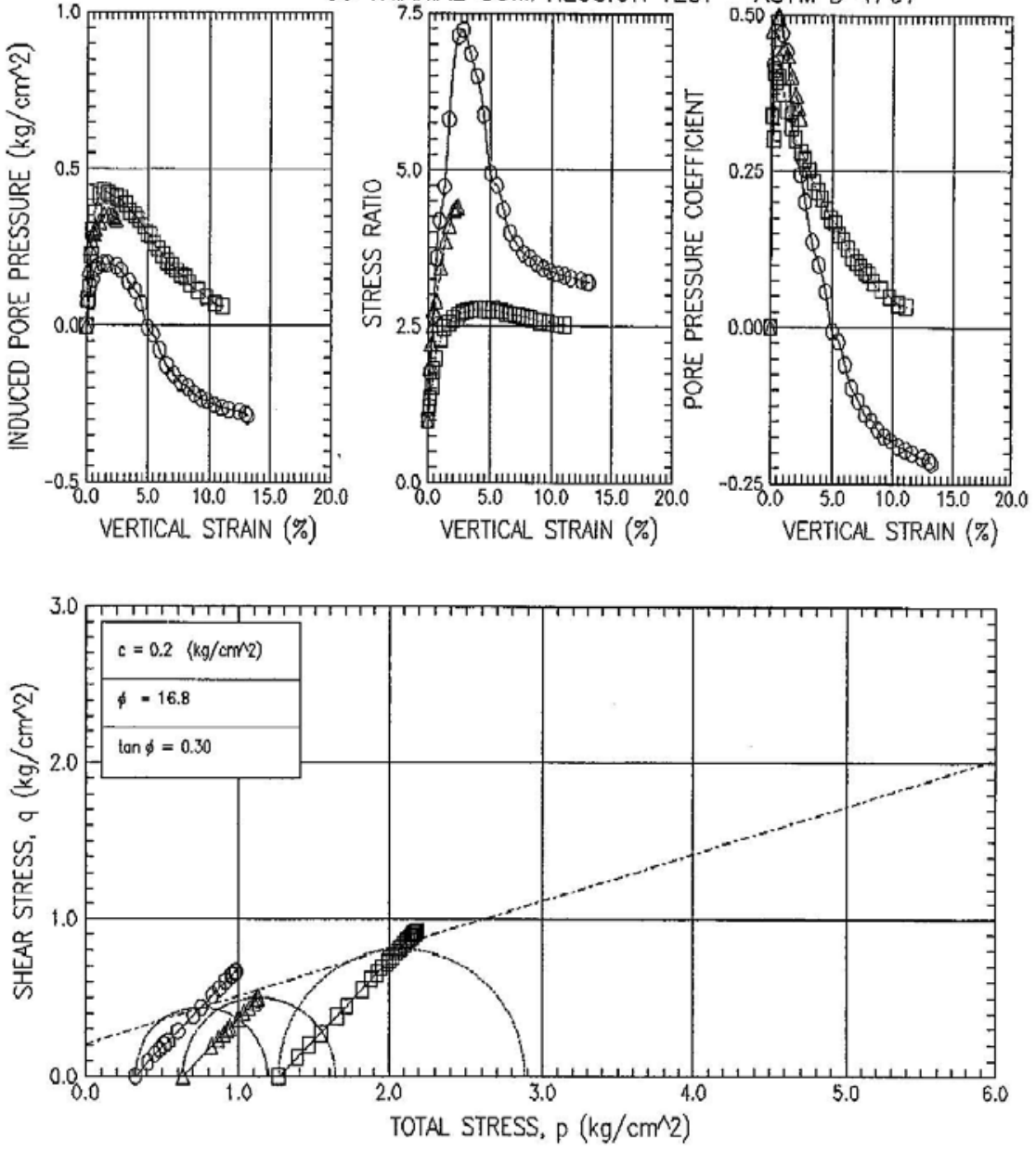

Project Name : ACOE - ALLEGAN COUNTY BLUFF

Boring No: Somple No Depth Test No Filename Symbol

$\begin{array}{lllll}\text { MPS-P-7 S-1 } & 10.0-11.0^{\prime} & 74257713 & 74257 T 13 . D A T\end{array}$

$\begin{array}{llllll}\text { MPS-P-7 } & \text { S- } 1 \quad 10.0-11.0^{\prime} & 74257 T 14 & 74257 T 14 . D A T\end{array}$

$\begin{array}{llllll}\text { MPS-P-7 } & \text { S-1 } & 10.0-11.0^{\prime} & 74257 T 15 & 74257 T 15 . D A T\end{array}$

0
$\Delta$
$\square$




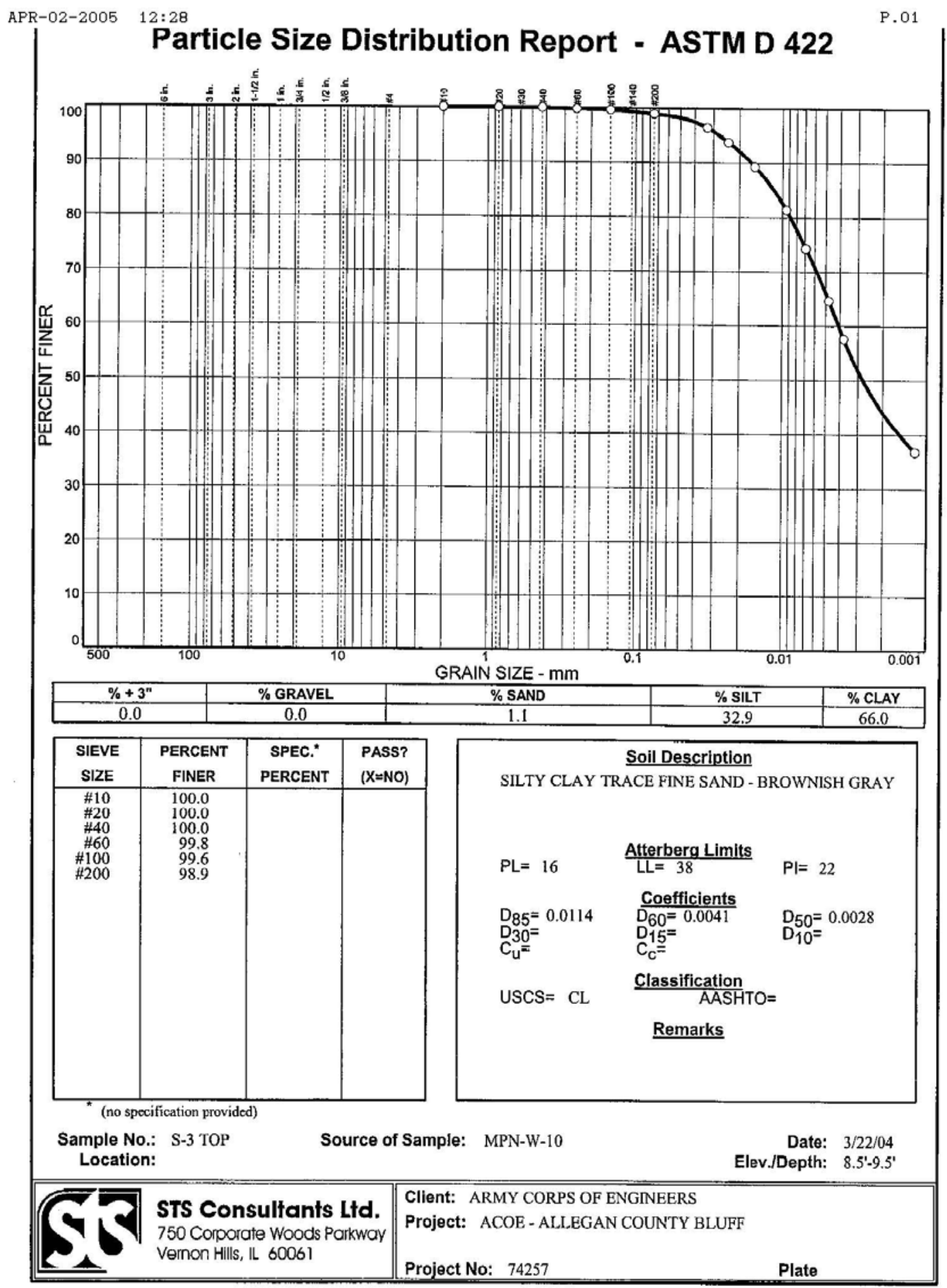




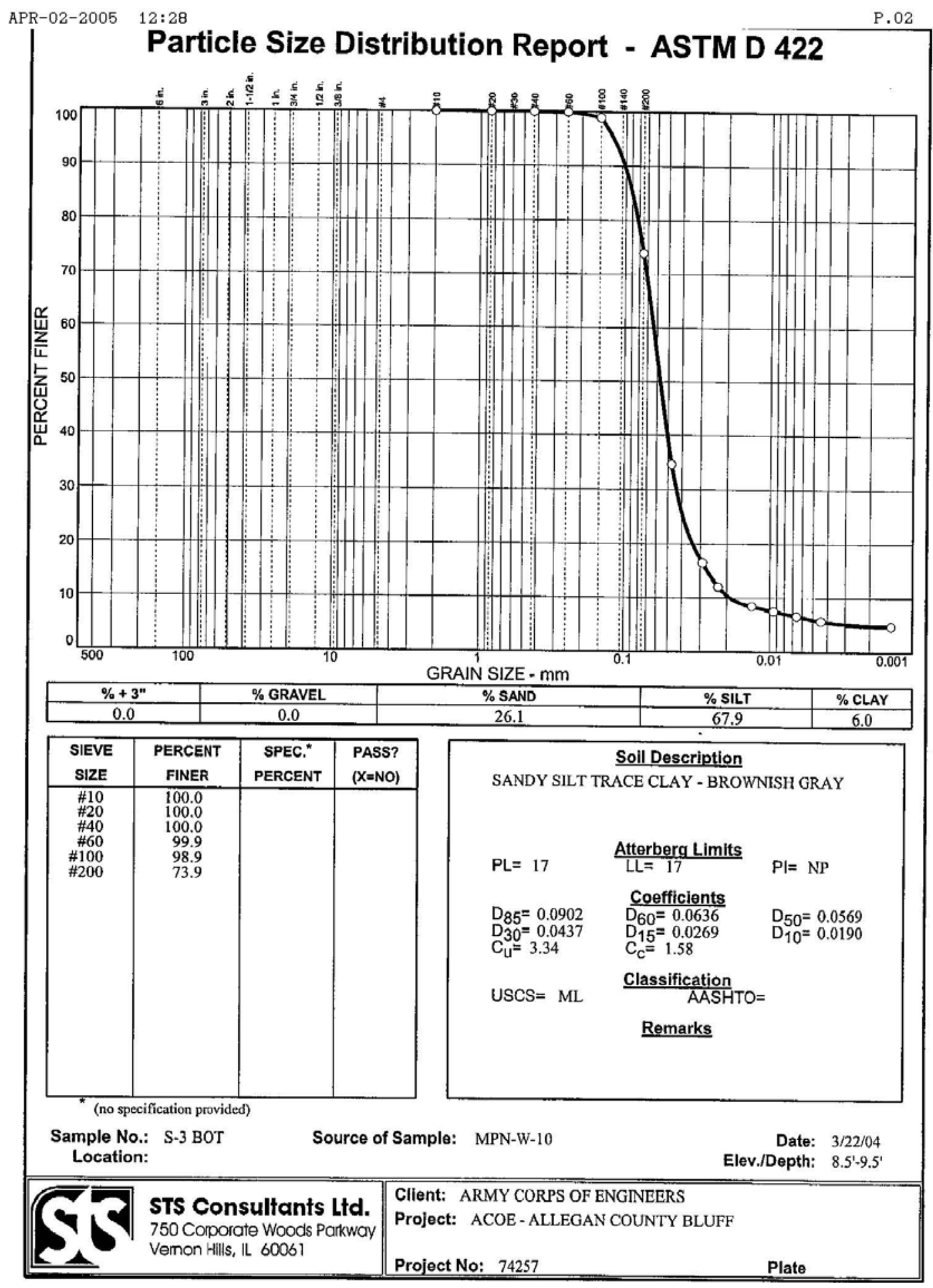




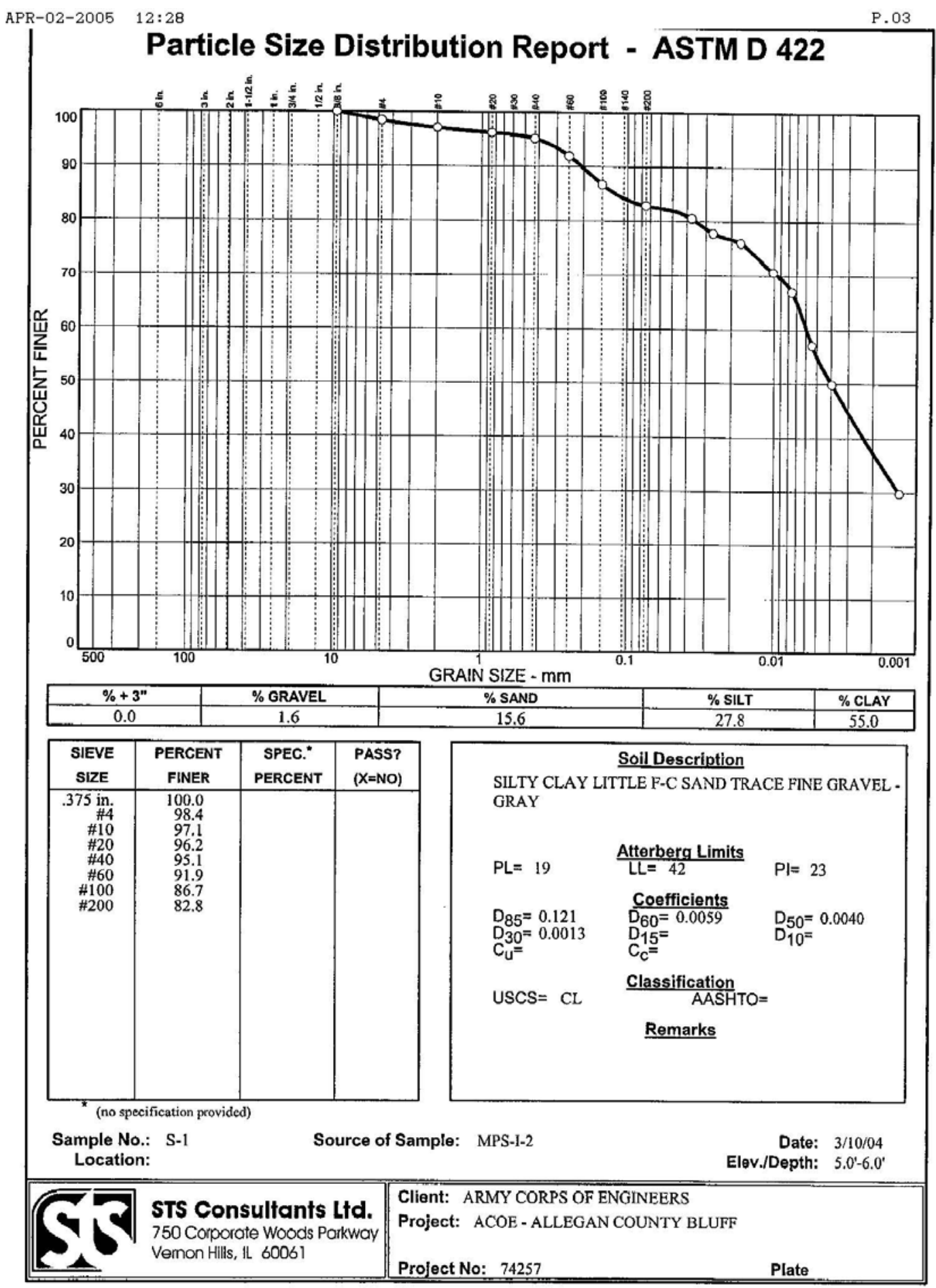




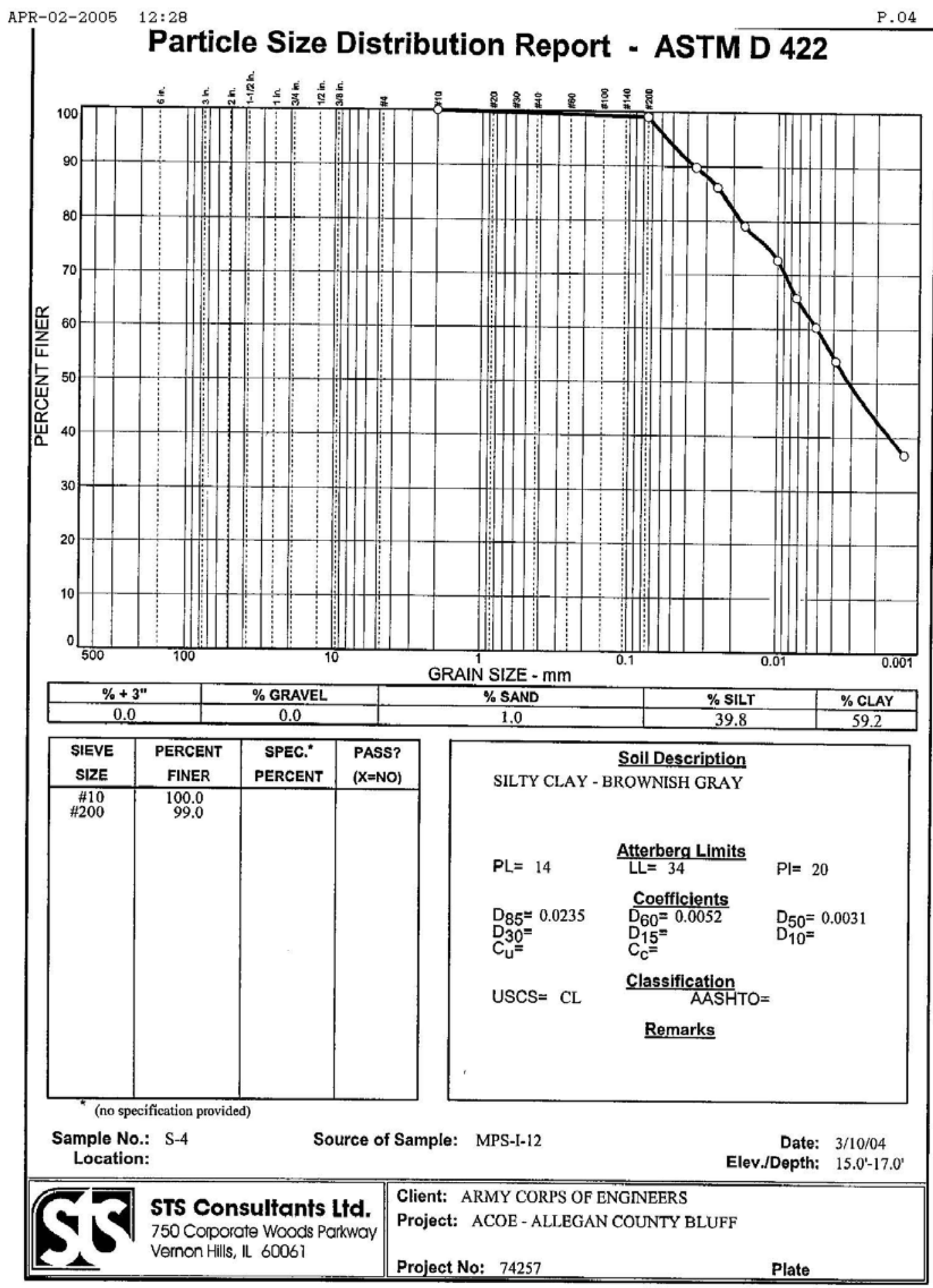




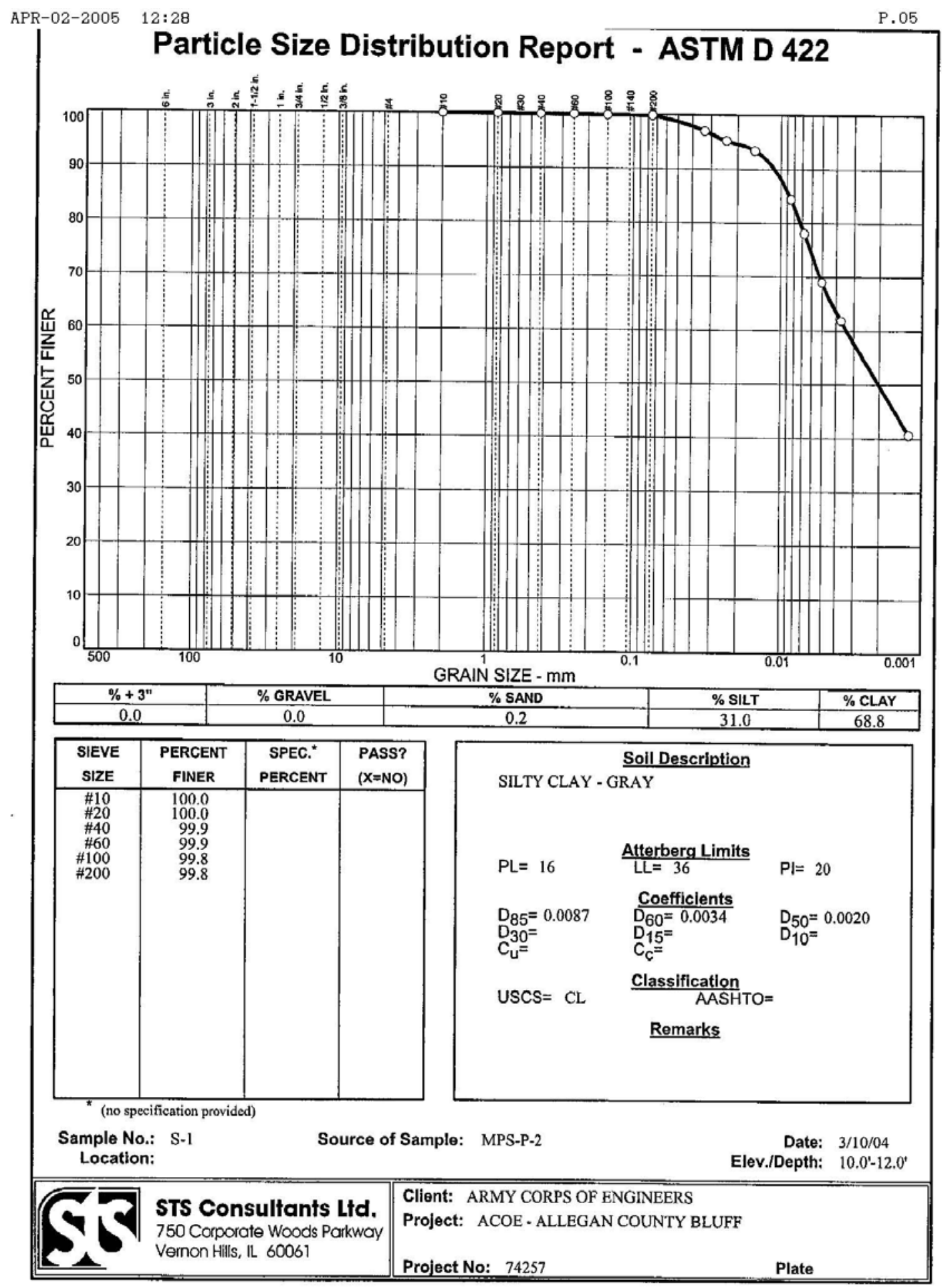




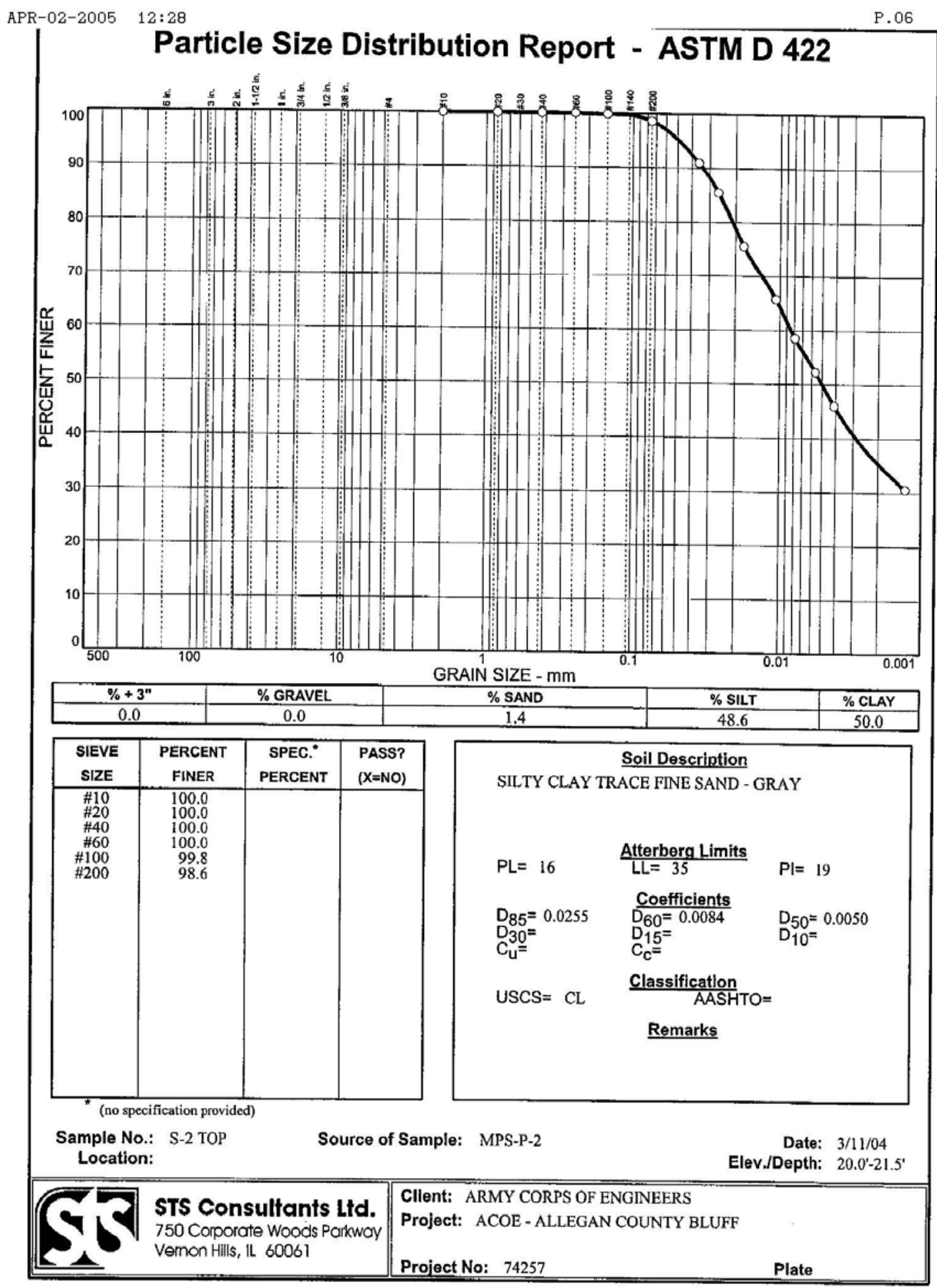




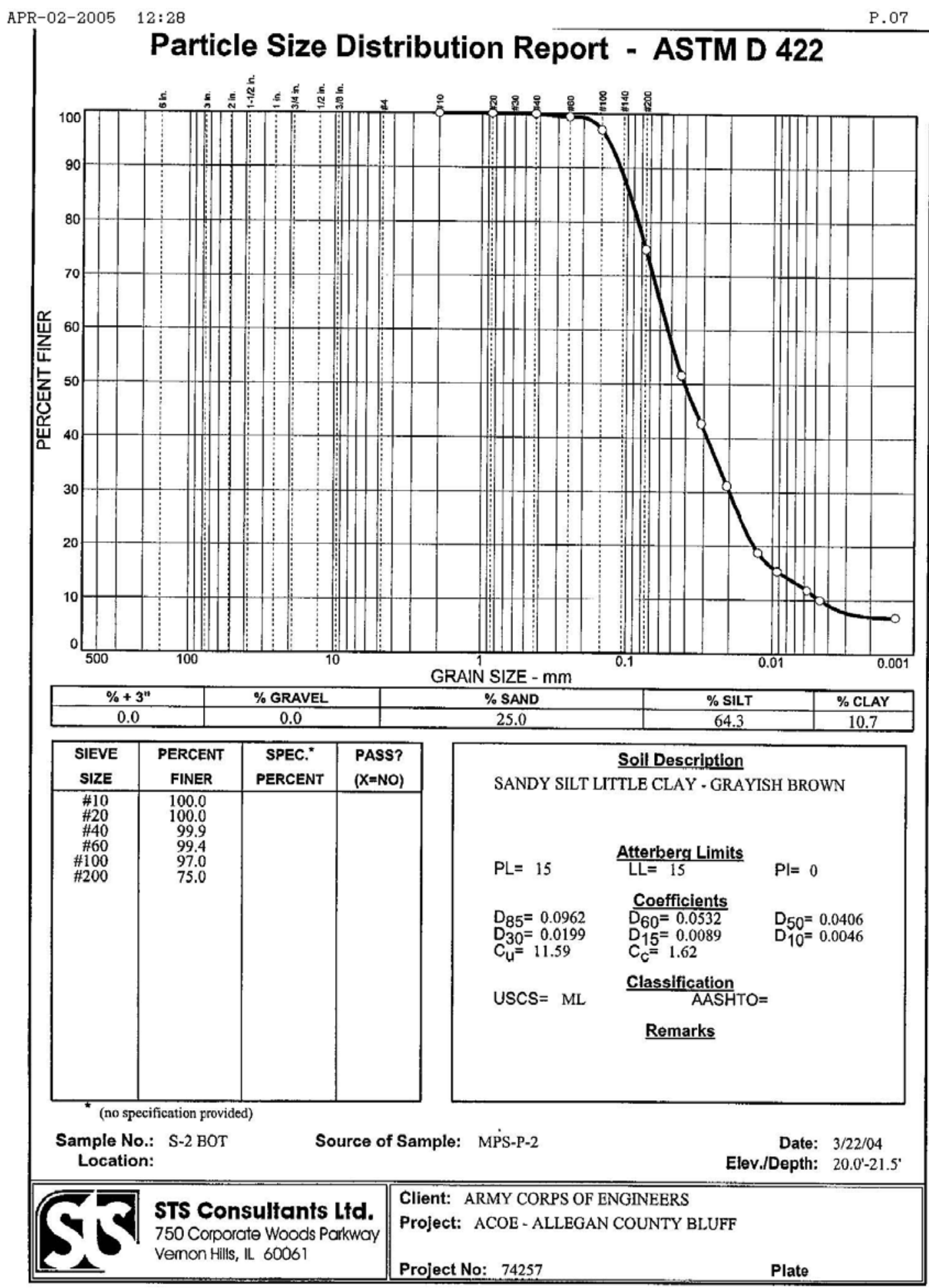




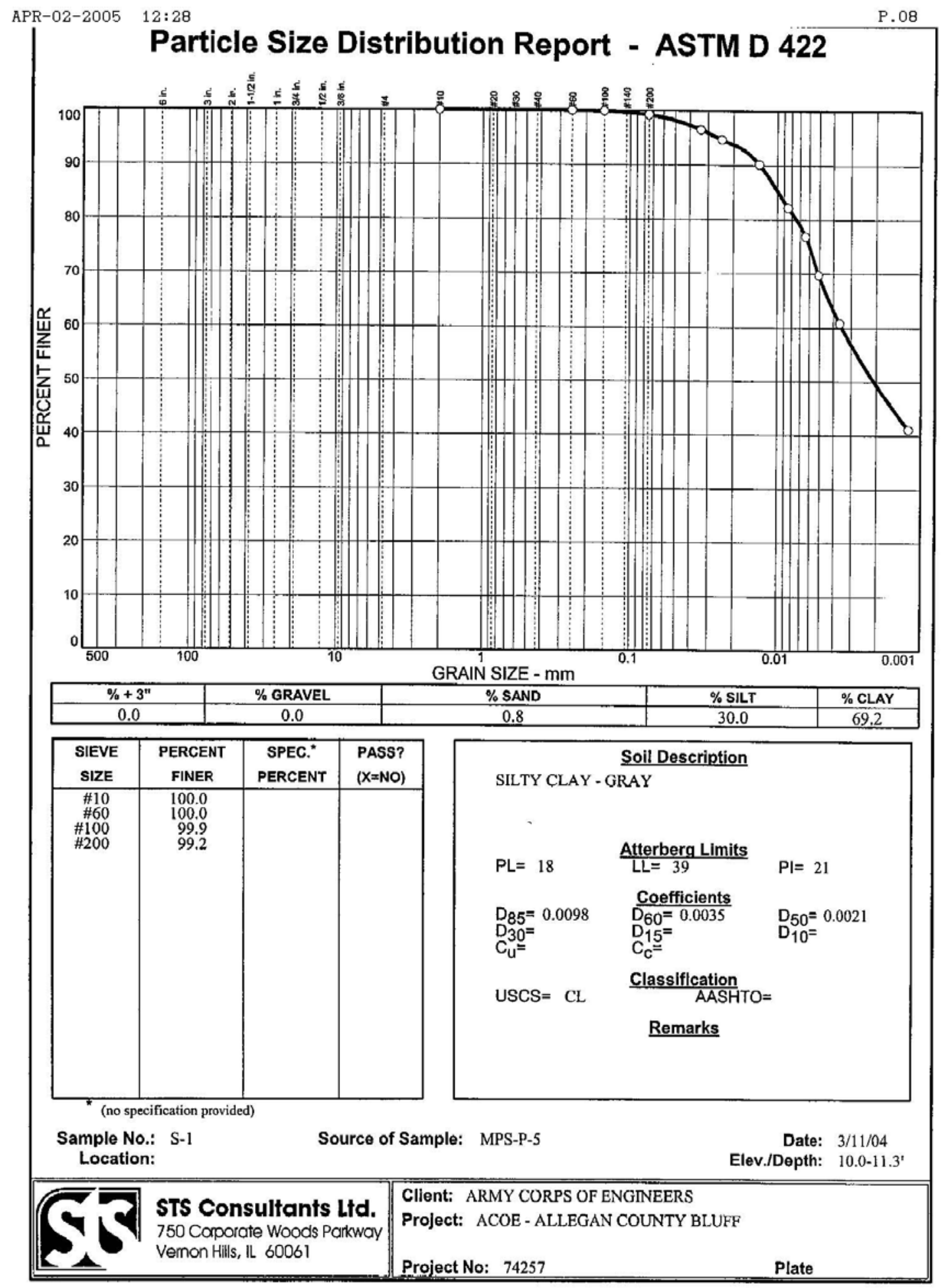




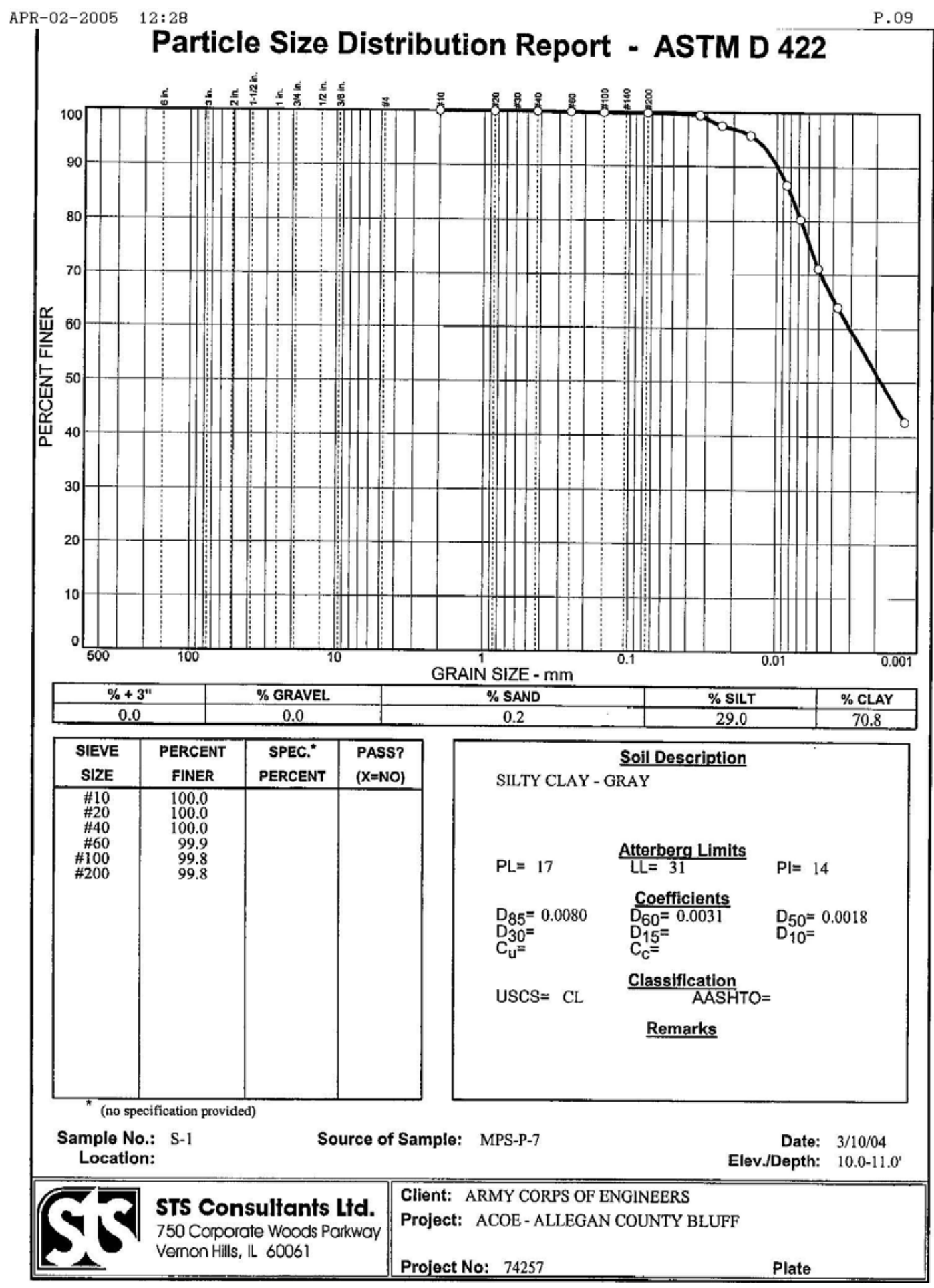




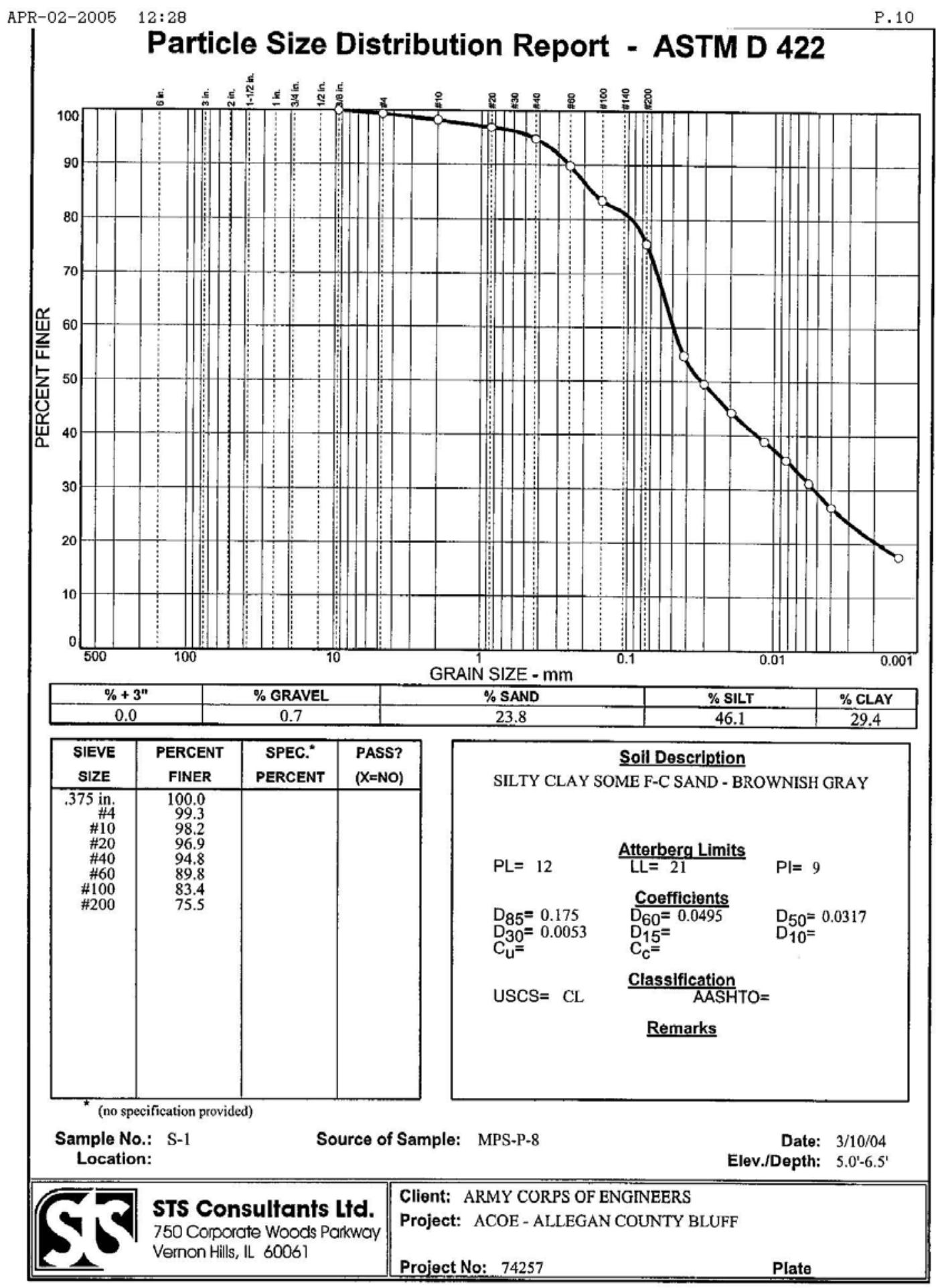




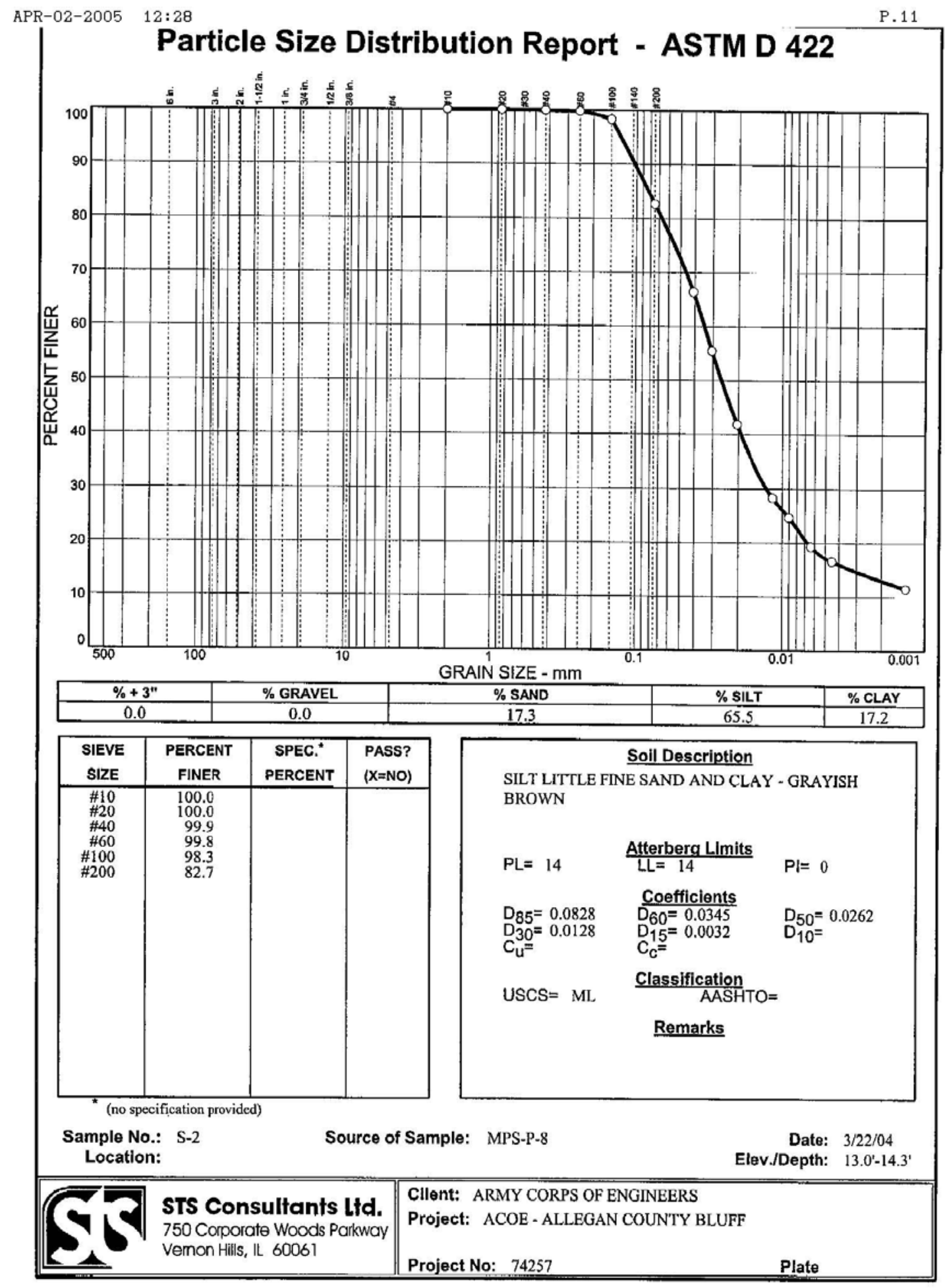




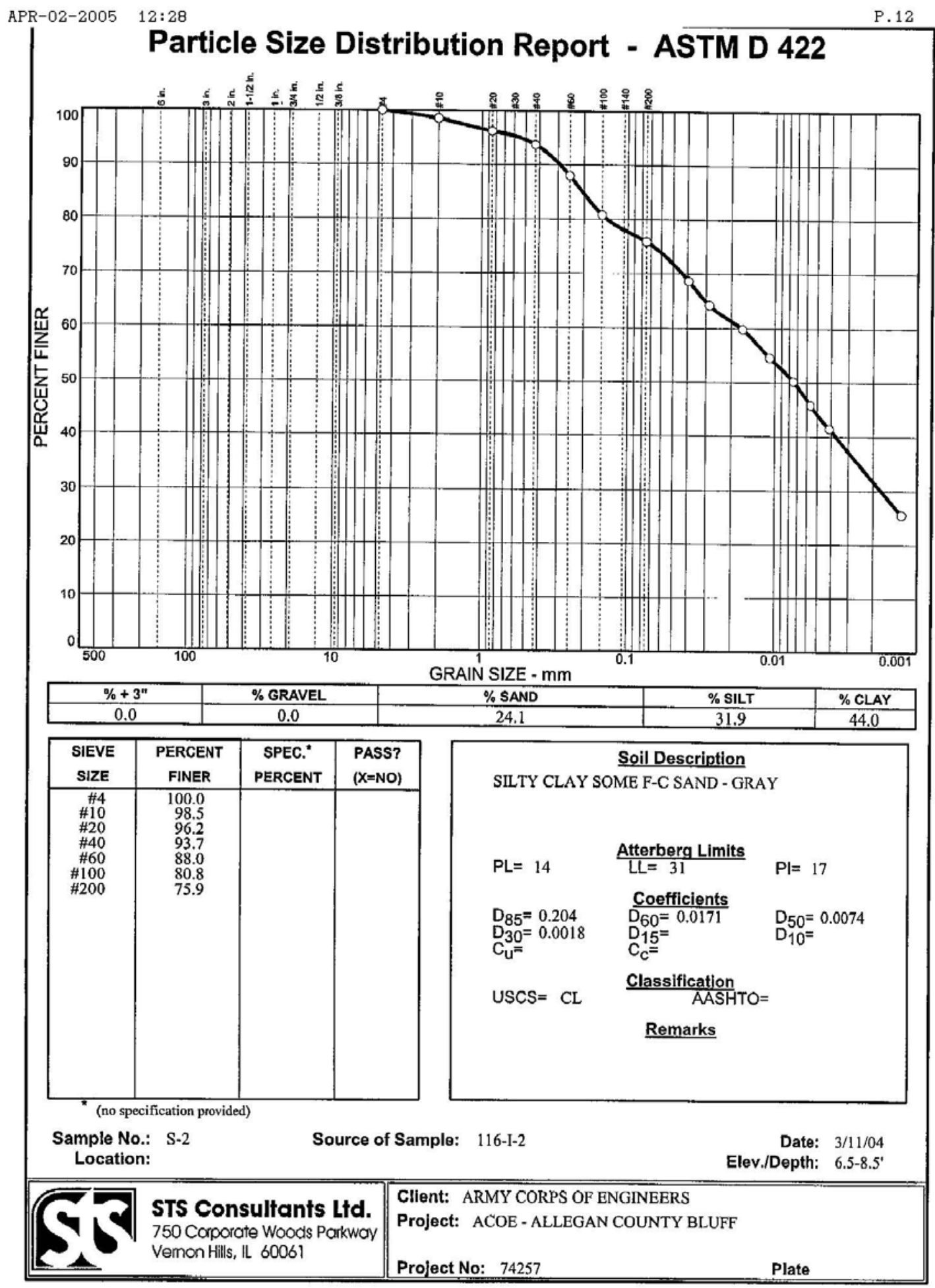




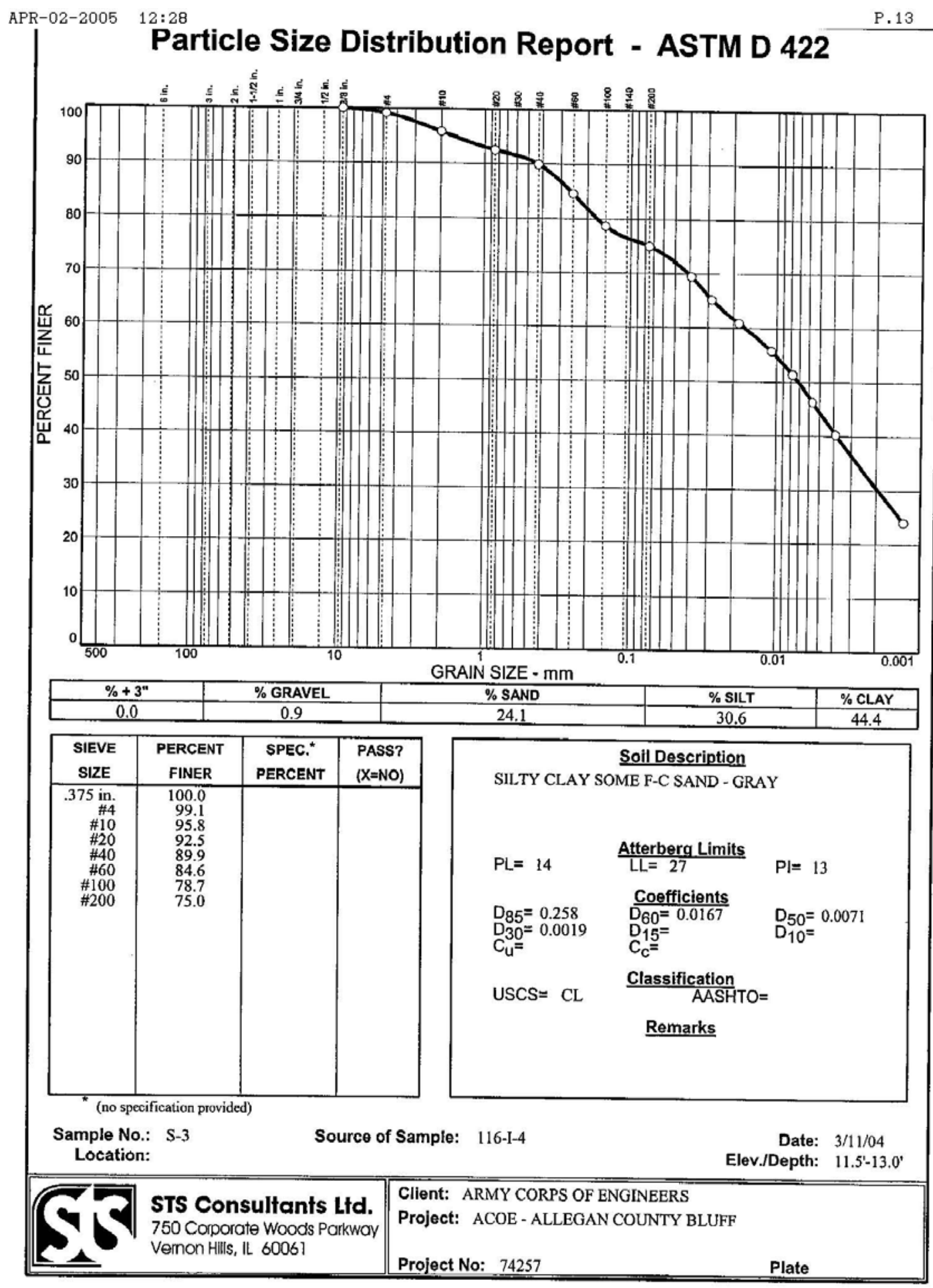




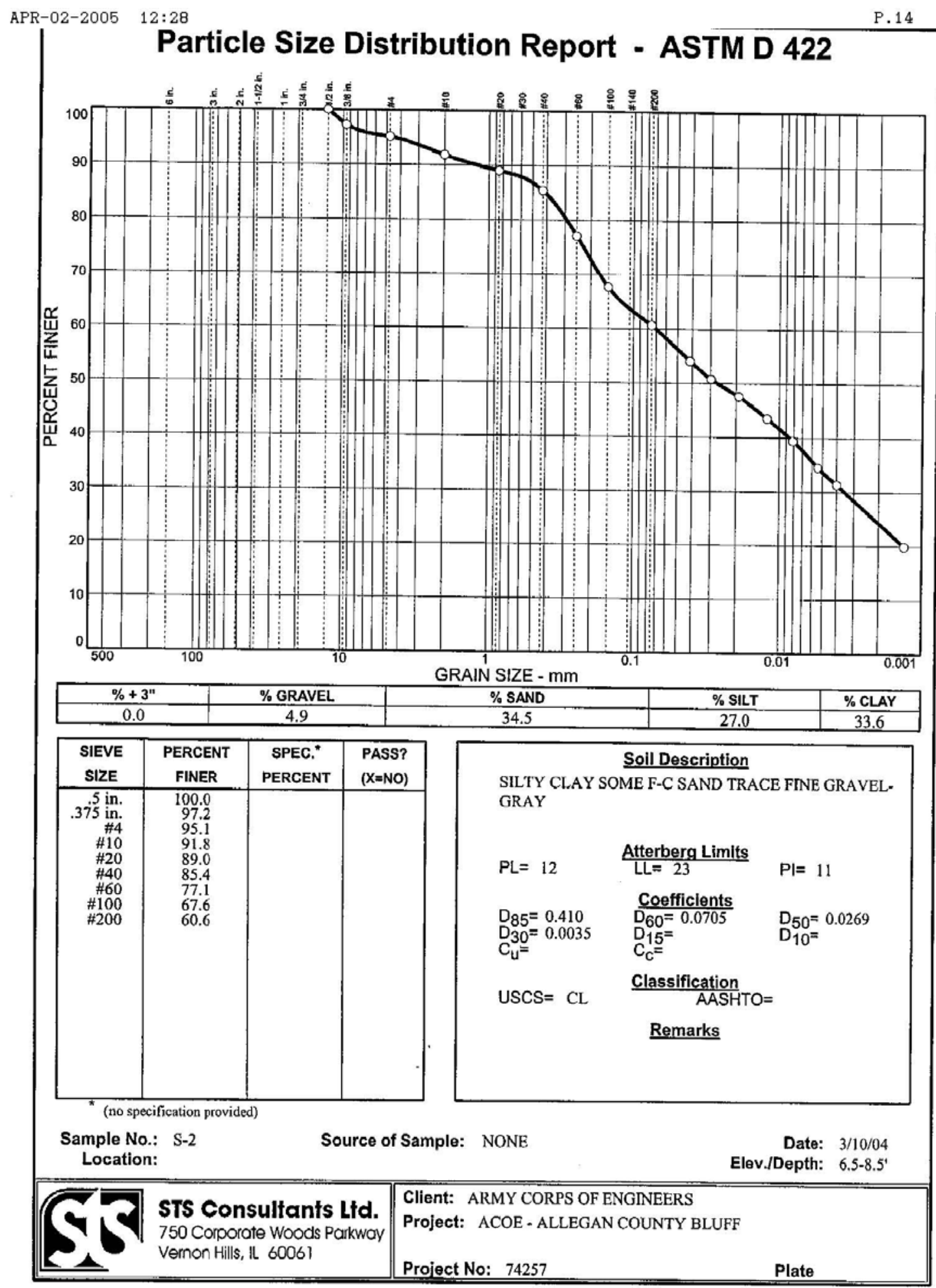




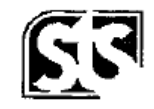

HYDRAULIC CONDUCTIVITY DETERMINATION

ASTM D 5084, METHOD C

STS Consultants, Ltd.

RISING TAIL WATER LEVEL

Laboratory Services Group

STS PROJECT NO. PROJECT NAME:

CLIENT NAME:
74257

Allegan County Bluff

$\mathrm{ACOE}$
750 Copprate Woods Pprkway Vernon Hills, Jllinois 60061

Phone:(847) 279-2500 F8x:(847) 279-2550

\section{SUMMARY OF TEST RESULTS}

BORING NO.
SAMPLE NO.
SAMPLE DEPTH
CLASSIFICATION
DRY UNIT
WEIGHT (pcf)
WATER CONTENT
(\%)
DIAMETER
(cm)
LENGTH
(cm)
HYDRAULIC GRADIENT
(MAXIMUM)
PERCENT
SATURATION
HYDRAULIC
CONDUCTIVITY
k (cm/SEC)

MPN-W-10

Bot

$8.5-9.5$

Sandy Silt - Brownish Gray ML

INITIAL

114.6

115.2

18.5

17.3

6.900

6.897

6.350

6.348

$2 / 16 / 2005$ 


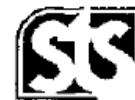

HYDRAULIC CONDUCTIVITY DETERMINATION

ASTM D 5084, METHOD C

RISING TAILWATER LEVEL

STS Consultants, Ltd.

Laboratory Services Group

750 Corporate Woods Parkway Vernon Hills, Illinois 60061

Phone:(847) 279-2500 Fax:(847) 279-2.

STS PROJECT NO.: $\quad \mathbf{7 4 2 5 7}$

PROJECT NAME: Allegan County Bluff

$2 / 16 / 2005$

CLIENT NAME:

ACOE

\section{SUMMARY OF TEST RESUL'TS}

BORING NO.
SAMPLE NO.
SAMPLE DEPTH
CLASSIFICATION

DRY UNIT
WEIGHT (PCf)
WATER CONTENT
(\%)
DIAMETER
(cm)
LENGTH
(cm)
HYDRAULIC GRADIENT
(MAXIMUM)
PERCENT
SATURATION
HYDRAULIC
CONDUCTIVITY
K (cm/SEC)

MPS-P-2

S-2 Bot

$20.0-22.5$

Sandy Silt Little Clay - Grayish Brown ML

Medium Sand Trace Clay -- Grayish Brown SM

INITIAL

$\begin{array}{ll}105.9 & 106.2\end{array}$

$\begin{array}{ll}8.8 & 16.4\end{array}$

7.259

7.252

3.474

3.471

6.3

77.0 (Percent saturation calculation is based on final measurements and an estimated specific gravity.)

$8.78 \mathrm{E}-05$

Deaired tap water was used as the liquid permeant. 


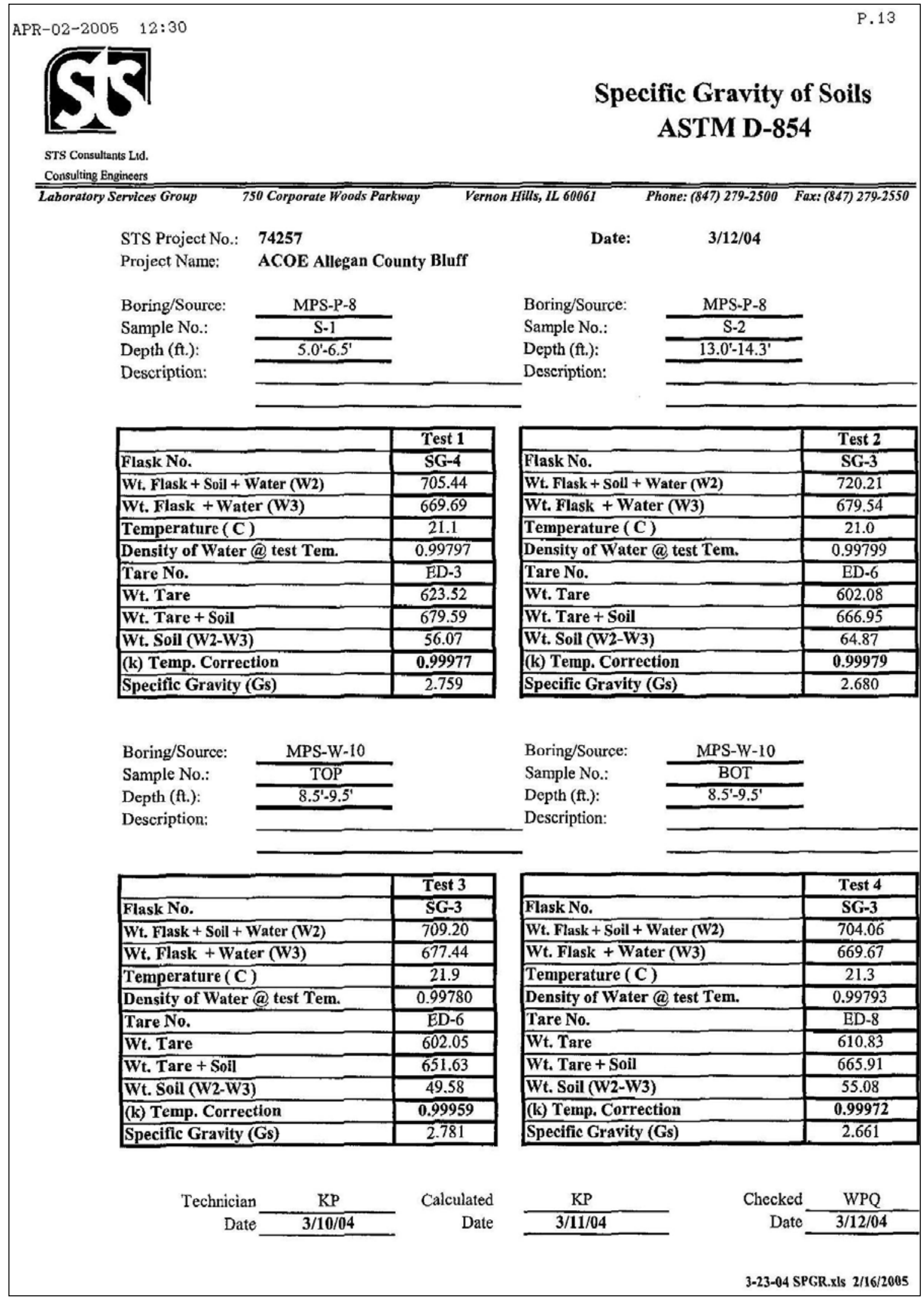




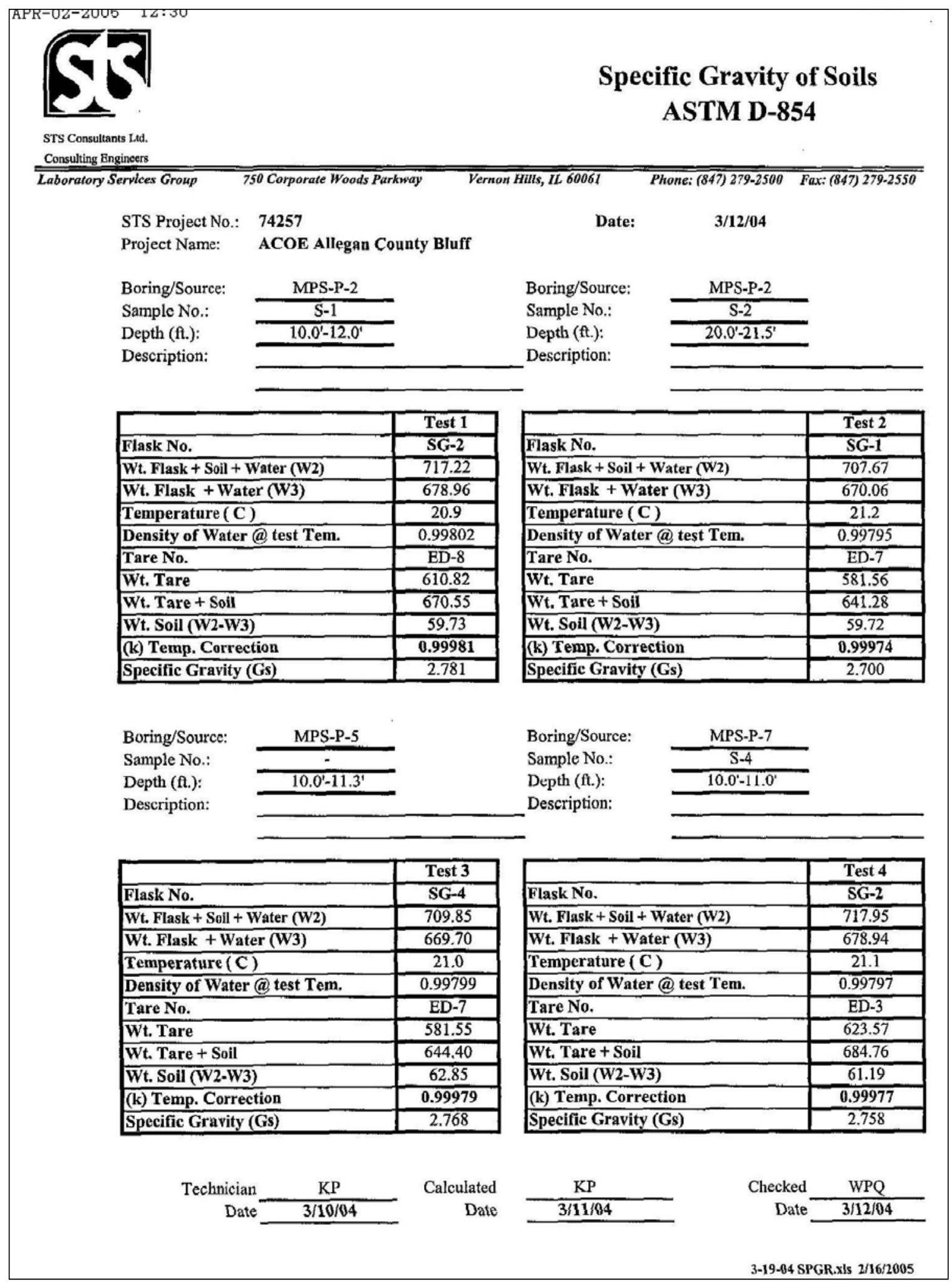




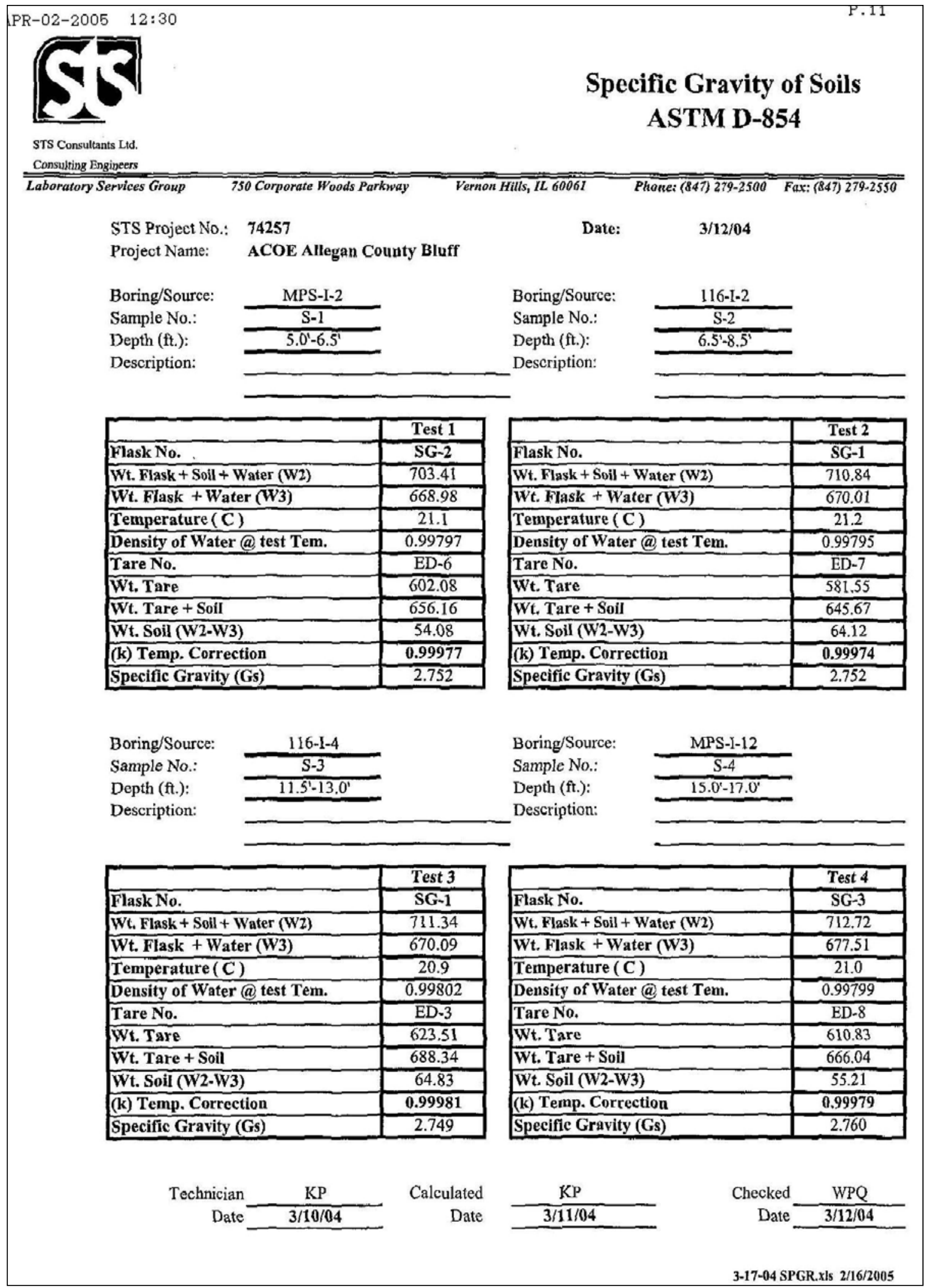




\section{Appendix D: General Description of Aquifer Testing at MPS (May 2004)}

Clarissa Hansen directed the aquifer testing and wrote this description. The testing team also included Chase, Kehew, and Kuanda, all of WMU, and Selegean of USACE, Detroit District. Construction support during the tests was provided by STS personnel.

\section{General description of piezometer locations}

Piezometer 1

This piezometer is located along the second cable line in the upper portion of the bluff. The ground surface elevation at this point is about $640.3 \mathrm{ft}$, and the piezometer was set at a depth of $23.5 \mathrm{ft}$ below the surface. This puts the piezometer elevation at $616.8 \mathrm{ft}$ in the upper clay layer. The initial head reading at this point was $616.53 \mathrm{ft}$, slightly below the piezometer elevation. The initial pressure reading was $-0.814 \mathrm{kPA}$, which is slightly outside the range listed on the calibration sheets ( 0 to $70 \mathrm{kPa}$ ). This measurement is believable.

Initially, the slope of the head was basically flat, before any pumping wells were activated.

When Well 8 began pumping, there was no change in slope. Well 8 is $41 \mathrm{ft}$ to the west and is screened in the middle sand layer.

During the pumping of Well 14, the slope remained constant and basically flat. Well 14 is located $132 \mathrm{ft}$ to the southwest and is screened in the upper and middle sand layers.

During the pumping of Well 9, there was again no change in slope. Well 9 is $67 \mathrm{ft}$ to the west and is screened in the middle sand layer.

It is difficult to determine the effect of Well 6 because of the lack of initial measurements before it began pumping. This well is $70 \mathrm{ft}$ to the northwest. 
Many of the piezometers displayed gradually increasing heads throughout Tuesday and into Wednesday morning. These piezometers suddenly turned and began to lose head from about noon to midnight Wednesday. That effect was not seen in this piezometer.

Most of the piezometers experienced an increase in head between the time the measurements stopped Wednesday night and the time they resumed Friday morning. This piezometer experienced a minor increase in head during this time, compared to the other piezometers.

There seems to have been no effect on the heads at this piezometer during the pumping of Well 3 . This well is $88 \mathrm{ft}$ to the northwest and is screened in the upper and middle sand layers.

It is unclear whether the head at this piezometer was affected when all the wells were activated. It might have slightly slowed the increasing head noted before the wells were activated.

\section{Piezometer 2}

This piezometer is located along the second cable line in the middle section of the bluff. The ground surface elevation at this point is about $620.9 \mathrm{ft}$. Since the piezometer was set at a depth of $36 \mathrm{ft}$, the elevation of the piezometer is $584.9 \mathrm{ft}$ and it is set in the middle sand layer. The initial head reading at this point is 585.3 , slightly above the piezometer elevation. The initial pressure reading was $1.52 \mathrm{kPa}$, which is inside the range of pressures listed on the calibration sheets ( 0 to $70 \mathrm{kPa}$ ). This measurement is believable.

Initially, the slope of the head-versus-time plot was slightly positive until the wells began pumping.

When Well 8 began pumping, the slope turned slightly negative, showing that there was a medium effect on the heads at Piezometer 2 from this well. Well 8 is $12 \mathrm{ft}$ to the south and is set in the same middle sand layer.

During the pumping of Well 14, the slope again became positive as the heads recovered from the changes effected by previous pumping. Thus, Well 14, does not seem to have affected this piezometer. This well is $120 \mathrm{ft}$ to the southwest and is screened in the middle sand layer. 
Well 9 exerted a minor effect on this piezometer, turning the slope negative. This well is $28 \mathrm{ft}$ to the west and is screened in the middle sand layer.

It is difficult to determine the effect of Well 6 , since there is no data immediately before the beginning of the pumping period. Well 6 is $37 \mathrm{ft}$ to the northwest and is screened in the middle sand layer.

This piezometer experienced a medium increase in head, which grew from Tuesday morning to about noon Wednesday, then dropped off until the piezometers stopped measuring about midnight that night.

This piezometer experienced a minor increase in head between Wednesday night and Friday morning.

The pumping at Well 3 had no discernible effect on the head at this piezometer. Well 3 is $82 \mathrm{ft}$ to the north and is screened in the upper and middle sand layers.

On Friday afternoon, when all the wells were pumping, this piezometer experienced a medium effect.

\section{Piezometer 3}

This piezometer is located along the second cable line in the lower section of the bluff. The ground surface elevation at this point is about $610.2 \mathrm{ft}$. The piezometer is set at a depth of $25 \mathrm{ft}$, making its el $585.2 \mathrm{ft}$. It is placed in the middle sand layer. The initial head reading at this location is 608.83, about $23 \mathrm{ft}$ above the piezometer elevation and just below the ground surface. The pressure is $70.7 \mathrm{kPa}$, slightly outside the range listed on the calibration sheets ( 0 to $70 \mathrm{kPa}$ ). It is hard to determine if these measurements are believable.

Initially, the head versus time plot for this piezometer has a slightly positive slope.

When Well 8 begins to pump, the positive slope continues almost constantly, showing that there is no communication between this well and Piezometer 3 . Well 8 is $25 \mathrm{ft}$ to the southeast and is screened in the middle sand layer. A greater effect was expected here since the well and the piezometer are so close and located in the same stratigraphic layer. 
During the pumping of Well 14, the slope continues on a positive track. The value of the slope decreases slightly but not significantly. Well 14 is not believed to have an effect on this piezometer. This well is $120 \mathrm{ft}$ to the south and is screened in the upper and middle sand layers.

Well 9 had a minor effect on the heads at Piezometer 3. The previously positive slope now becomes negative. Well 9 is located $13 \mathrm{ft}$ to the south and is screened in the middle sand layer.

It is difficult to determine what effect the pumping at Well 6 had on any of the piezometers because of the lack of data immediately before the test. This well is located $28 \mathrm{ft}$ to the northeast and is screened in the middle sand layer.

This piezometer experienced a medium increase in head between Monday morning and Wednesday noon. This increase in head was reversed during the afternoon and evening hours of Wednesday.

A medium increase in head also was experienced between Wednesday night and Friday morning.

Well 3 seemed to have no effect on the head at this piezometer. It is $78 \mathrm{ft}$ to the northeast and is screened in the upper and middle sand layers.

The pumping of all the wells simultaneously Friday afternoon had a minor effect on the heads at this piezometer. The previously positive slope on the head-versus-time plot, changed to a nearly zero slope. During all the measurements Friday, this piezometer had trouble with oscillation between two values. This is visible on the plots as two separate lines of points. The magnitude of the oscillation seemed to increase as the day progressed. The reason is unknown.

\section{Piezometer 4}

This piezometer is located along the second cable line in the lower section of the bluff. The ground surface elevation at this point is about $596.4 \mathrm{ft}$. The piezometer is set at a depth of $18 \mathrm{ft}$, making the elevation at the piezometer $578.4 \mathrm{ft}$. It is set in the middle sand layer. The initial head reading at this point was $544.83 \mathrm{ft}$, more than $30 \mathrm{ft}$ below the elevation of the piezometer. The pressure at this point is $-100 \mathrm{kPa}$, well outside the range listed on the calibration sheets ( 0 to $70 \mathrm{kPa}$ ). These head values are 
not believable. It is hoped that the differentials in the head-versus-time plots are accurate, even if the initial values are not.

Initially, the head-versus-time plot at this piezometer had a very slightly positive slope.

During the pumping of Well 8, the slope continued in the same trend and felt no effects. Well 8 is $46 \mathrm{ft}$ to the east-southeast and is screened in the middle sand layer.

Well 14 also had no effect on the slightly increasing trend of the head at this piezometer. This well is $123 \mathrm{ft}$ to the south and is screened in the upper and middle sand layers.

The heads at this piezometer seemed to have a slight downward slope during the pumping of Well 9. Because of the short duration of the data collection, this downward slope could be noise in the data points. Well 9 is $22 \mathrm{ft}$ to the east-southeast and is screened in the middle sand layer.

It is difficult to determine what effect the pumping at Well 6 had on any of the piezometers because of the lack of data immediately before the test. This well is $33 \mathrm{ft}$ to the northeast and is screened in the middle sand layer.

The heads at this piezometer showed a minor peak Wednesday. They slowly increased from the beginning of the data set until they began to turn down about noon Wednesday. The downward trend continued until the data collection ceased around midnight Wednesday.

This piezometer also showed a medium increase in heads between Wednesday night and Friday morning, when compared to other piezometers.

Well 3 seemed to have no effect on the heads at this piezometer. This well is $79 \mathrm{ft}$ to the northeast and is screened in the upper and middle sand layers.

It is hard to determine if the piezometer heads were affected by the activetion of all extraction wells Friday afternoon. The slope of the head-versustime plot had been slowly decreasing all day, and that decrease continued 
through the pumping of the entire group of dewatering wells. If there was an effect, it was minor.

\section{Piezometer 5}

Piezometer 5 is north of the first cable line in the middle section of the bluff face. The ground surface elevation at this point is about $612.2 \mathrm{ft}$, and the piezometer is set at a depth of $16.75 \mathrm{ft}$. Thus, the piezometer elevation is about $595.5 \mathrm{ft}$, and it is set near the interface between the upper and middle sand units. The initial head measurement at this point was $647.42 \mathrm{ft}$, more than $50 \mathrm{ft}$ above the piezometer elevation and $35 \mathrm{ft}$ above ground surface. The initial pressure reading was $155 \mathrm{kPa}$, well outside of the range listed on the calibration sheets ( 0 to $70 \mathrm{kPa}$ ). These head values are not believable. Hopefully the differentials are accurate, even if the initial value is not.

Unlike most of the other piezometers, this piezometer began with a slightly negative slope.

The pumping at Well 8 had no effect on this slope; the downward trend continued. Well 8 is $103 \mathrm{ft}$ to the south and is screened in the middle sand layer.

Well 14 also failed to cause a change in this initial trend. This well is $209 \mathrm{ft}$ to the southwest and is screened in the upper and middle sand layers.

Well 9, located $102 \mathrm{ft}$ to the southwest, caused no change in the general trend of the head at this piezometer. This well is screened in the middle sand layer.

It is difficult to determine the effect of Well 6 on any of the piezometers because there is no data immediately before the test. This well is $61 \mathrm{ft}$ to the southwest and is screened in the middle sand layer.

This piezometer did not experience the peak in heads that many other piezometers experienced Wednesday.

This piezometer did, however, see an increase in head between the time the piezometers stopped measuring Wednesday night and the time they turned back Friday morning. We can classify this increase as medium when compared to the other piezometers, but the behavior Friday of the 
piezometer is peculiar. Instead of a smooth, increasing slope, the head increases in step fashion.

Well 3 seemed to have no effect on this piezometer; however, the odd behavior of the piezometer make this hard to determine. Well 3 is $15 \mathrm{ft}$ to the southwest and is screened in the upper and middle sand layers. A greater degree of communication was expected here.

It also is unclear whether the heads at this piezometer were affected Friday afternoon when all the wells were activated. The stair-step nature of the head-versus-time plot makes it difficult to determine.

\section{Piezometer 6}

This piezometer is between the first and second cable lines in the middle section of the bluff. The ground surface elevation is about $619.9 \mathrm{ft}$. The piezometer was set at a depth of $20 \mathrm{ft}$, making the piezometer el 599.9. The instrument is set in the middle sand layer. The initial head reading from the piezometer was 599.63, slightly below the piezometer elevation. The initial pressure measurement was $-0.791 \mathrm{kPa}$, slightly outside the range listed on the instrument calibration sheets ( 0 to $70 \mathrm{kPa}$ ).

Initially, Piezometer 6 had a very slightly decreasing (almost flat) slope.

During the pumping at Well 8 , this was basically unchanged. This well is $56 \mathrm{ft}$ to the south-southwest. It is screened in the middle sand layer.

Well 14 also did not have any effect on the head at this piezometer. This well is $164 \mathrm{ft}$ to the southwest and is screened in the upper and middle sand units.

In addition, Well 9 did not have an effect on conditions at this piezometer. Well 9 is $61 \mathrm{ft}$ to the southwest.

It is difficult to determine if Well 6 had an effect on any of the piezometer head data because of a lack of data points immediately before the test.

Since this well is $28 \mathrm{ft}$ to the west and is screened in the same middle sand unit, it would be most likely to affect heads at this piezometer than at more distant piezometers. 
Unlike many of the other piezometers, there was no distinct peak in the heads around Wednesday at noon. The slowly decreasing trend continued uninterrupted until about midnight Wednesday.

This piezometer did have a minor increase in head between Wednesday night and Friday morning.

Well 3 did not seem to have an effect on this piezometer. It is $43 \mathrm{ft}$ to the southwest and is screened in the upper and middle sand layers.

It is unclear whether there was any effect while all the wells were pumping Friday afternoon. The slope of the head-versus-time plot decreased slightly as time passed Friday, but it is unclear whether the continued decrease in slope would have happened without the pumping in the afternoon.

\section{Piezometer 7}

Piezometer 7 is south of the third cable line in the upper section of the bluff. Ground surface elevation at this point is $630.6 \mathrm{ft}$. The piezometer was set at a depth of $19 \mathrm{ft}$, making the elevation of the piezometer $611.6 \mathrm{ft}$. It was set in the upper sand level. The initial head reading at this point was $644.81 \mathrm{ft}$, more than $30 \mathrm{ft}$ above the piezometer and almost $15 \mathrm{ft}$ above ground surface. The initial pressure reading was $99.4 \mathrm{kPa}$, outside the range listed on the instrument calibration sheets ( 0 to $70 \mathrm{kPa}$ ). These head values are not believable, but hopefully the differentials are accurate.

The results from this piezometer are very noisy, but in general the initial measurements indicated a positive slope, steeper than any of the other piezometers.

During the pumping at Well 8, the head at this piezometer turned to have a slightly negative slope, a medium effect, when compared to other piezometers. Well 8 is $42 \mathrm{ft}$ to the northwest and is screened in the middle sand layer.

During the pumping at Well 14, the heads recovered slightly and returned to a positive slope. This well is $83 \mathrm{ft}$ to the southwest and is screened in the upper and middle sand layers. 
Well 9 had a major effect on the heads at Piezometer 7, causing a very steep slope. This well is $60 \mathrm{ft}$ to the northwest and is screened in the middle sand layer.

It is hard to tell if Well 6 affected the heads at this piezometer due to the lack of data points before the pumping at this well. Well 6 is $89 \mathrm{ft}$ to the northwest and is screened in the middle sand layer.

This piezometer showed a major peak at noon Wednesday. The peak resulted from a gradual increase in head from Tuesday morning through Wednesday morning. The heads then began to decrease and continued in that trend until the piezometers stopped recording around midnight Wednesday.

Compared to other piezometers, the increase in head that occurred between Wednesday night and Friday morning is categorized as medium.

No effect on the heads at this piezometer is noted during the pumping at Well 3. This well is $135 \mathrm{ft}$ north of the piezometer and is screened in the upper and middle sand layers.

During the pumping of all wells, this piezometer had a medium response. The previously positive slope turned negative as soon as the wells were activated.

\section{Piezometer 8 Shallow}

This piezometer is south of the third cable line in the lower section of the bluff. The ground surface is at an elevation of $614 \mathrm{ft}$, and the piezometer was placed $10.5 \mathrm{ft}$ below the surface. The piezometer elevation is 603.5, and it was placed in the upper clay layer. The initial head reading at this point was $549.2 \mathrm{ft}$, almost $15 \mathrm{ft}$ below the piezometer. The initial pressure reading was $-163 \mathrm{kPa}$, well beyond the range listed on the instrument calibration sheets (0 to $70 \mathrm{kPa}$ ).

Initially, the head-versus-time plot had a general upward trend that was fairly steep.

This positive slope continued through the pumping at Well 8. This well is $44 \mathrm{ft}$ to the northeast of the piezometer location and is screened in the middle sand layer. 
Well 14 also had no effect on the increasing heads at this piezometer. This well is $66 \mathrm{ft}$ to the southwest and is screened in the upper and middle sand layers.

Well 9 had a minor effect on the heads at Piezometer 8, turning the slope negative. This well is $43 \mathrm{ft}$ north of the piezometer and is screened in the middle sand layer.

It is hard to tell if the pumping at Well 6 affected the head at Piezometer 8 because there is no data immediately before the pumping began. This well is $83 \mathrm{ft}$ northeast of the piezometer and is screened in the middle sand layer.

When compared with the other piezometers, the peak experienced by this piezometer around noon Wednesday is major. The increase that began Tuesday continued until midday Wednesday, then turned around and the heads decreased until the piezometers stopped recording around midnight.

The major increase that occurred in the head measurements between Wednesday night and Friday morning (more than $1 \mathrm{ft}$ ) is one of the largest jumps among the piezometers.

The pumping at Well 3 seems to have had no effect on the head at this piezometer. This well is $132 \mathrm{ft}$ northeast of the piezometer and is screened in the upper and middle sand layers.

There might have been a minor effect on heads at this piezometer Friday afternoon when all the wells were activated. It is hard to tell if the decreasing slope in the head-versus-time plot is caused by the pumping or if it is just a continuation of the trend earlier Friday.

\section{Piezometer 8 Deep}

This piezometer is located south of the third cable line in the lower section of the bluff. The ground surface elevation at this point is $614 \mathrm{ft}$, and the piezometer was set at a depth of $27 \mathrm{ft}$. The piezometer elevation, then, is $587 \mathrm{ft}$, and it is set in the middle sand layer. The initial head reading at this point was $564.9 \mathrm{ft}$, more than $20 \mathrm{ft}$ below the piezometer elevation. The initial pressure reading was $-66.1 \mathrm{kPa}$, outside the range listed on the instrument calibration sheets ( 0 to $70 \mathrm{kPa}$ ). This is not a believable head value, but hopefully the differentials are still accurate. 
The initial readings yielded a head-versus-time plot with a positive slope.

The positive slope continues through the pumping of Well 8 without causing any effects at this piezometer. This well is $44 \mathrm{ft}$ northeast of the piezometer and is screened in the middle sand layer.

The pumping at Well 14 also fails to cause any change in the upward trend of the heads at Piezometer 8 Deep. This well is $66 \mathrm{ft}$ southwest of the pumping well and is screened in the upper and middle sand units.

The pumping at Well 9, however, has a major impact on the heads at this piezometer, and results in a steep negative slope on the head-versus-time plot. This well is $43 \mathrm{ft}$ to the north and is screened in the middle sand layer.

It is hard to tell if the pumping in Well 6 had any effect on the heads at this piezometer because there is no previous data to use for comparison. This well is $83 \mathrm{ft}$ to the northeast and is screened in the middle sand layer.

A medium size peak is noted on Wednesday afternoon. Heads at this piezometer steadily increased beginning on Tuesday. The increasing trend suddenly reversed itself and the heads dropped steadily from noon on Wednesday until the piezometers stopped recording around midnight that same day.

A minor increase in head was noted between Wednesday night and Friday morning.

The pumping at Well 3 seemed to have no effect on the increasing heads at this piezometer. The well is $132 \mathrm{ft}$ to the northeast and is screened in the upper and middle sand layers.

A major effect was noted Friday afternoon when all the wells began pumping together. The slope at this piezometer was more negative than that at any other piezometers during the pumping of all the wells.

\section{Piezometer 9 Shallow}

This piezometer is located north of the fourth cable line, in the lower section of the bluff. The ground surface elevation at this point is about $612.1 \mathrm{ft}$. The piezometer was placed at a depth of $6 \mathrm{ft}$, making its elevation $606.1 \mathrm{ft}$ and 
placing it in the upper sand unit. The initial head reading at this piezometer was $569.37 \mathrm{ft}$, putting the water table more than $30 \mathrm{ft}$ below the piezometer. The initial pressure reading was $-110 \mathrm{kPa}$, well outside the range listed on the instrument calibration sheets ( 0 to $70 \mathrm{kPa}$ ). These head readings are not believable, but hopefully the differentials are correct.

The initial slope on the head-versus-time plot is positive.

The slope continued virtually unchanged through the pumping of Well 8. This well is $116 \mathrm{ft}$ northeast of the piezometer and is screened in the middle sand layer.

When Well 14 began pumping, however, it caused an immediate and steep drop in heads at Piezometer 9 Shallow. This is the only piezometer that showed any change as a result of the pumping at this well. The well is $10 \mathrm{ft}$ north of the piezometer and is screened in the upper and middle sand layers.

By the time Well 9 began pumping, the head at this piezometer had mostly recovered and the slope turned positive again. Well 9 is $116 \mathrm{ft}$ north of the piezometer and is screened in the middle sand layer.

It is difficult to determine if Well 6 had an effect on this piezometer because of the lack of data immediately before the test began. This well is $156 \mathrm{ft}$ north of the piezometer and is screened in the middle sand layer.

A medium-sized peak (when compared to other piezometers at the site) occurred in the head-versus-time plot for this piezometer around noon Wednesday. It was the result of increasing head since the data collection began Tuesday. Around noon, the positive slope suddenly turned negative and the heads slowly decreased until about midnight when the piezometers stopped recording.

The major change in head between Wednesday night and Friday morning at this piezometer is greater than what was measured in any of the other piezometers.

Well 3 does not seem to have affected the heads at this piezometer while it was pumping Friday morning. This well is $206 \mathrm{ft}$ north of the piezometer and is screened in the upper and middle sand layers. 
A major drop in head occurred at this piezometer Friday afternoon when all of the wells were turned on for a short while.

\section{Piezometer 9 Deep}

This piezometer is north of the fourth cable line in the lower section of the bluff. The ground surface elevation at this point is 612.1, and the piezometer was set at a depth of $22.5 \mathrm{ft}$. The piezometer elevation is $589.6 \mathrm{ft}$, and it is set in the middle sand layer. The initial head reading at this point was $628.19 \mathrm{ft}$, more than $35 \mathrm{ft}$ above the piezometer and more than $15 \mathrm{ft}$ above ground surface. The initial pressure measurement was $116 \mathrm{kPa}$, outside the range listed on the instrument calibration sheets ( 0 to $70 \mathrm{kPa}$ ). These measurements are not believable, but hopefully the differentials are correct.

Initially, this piezometer showed a decreasing head.

This decreasing trend continued through the pumping at Well 8. This well is $116 \mathrm{ft}$ northeast of the piezometer and is screened in the middle sand layer.

While Well 14 is pumping, the trend at first continues downward; but, about the middle of the test, there is a sudden, small increase in head, then the downward trend continues from that point at about the same slope. The cause of this anomaly is unknown, but a similar effect is seen throughout the data set for this piezometer. Well 14 is considered to have no effect on this piezometer. It is $10 \mathrm{ft}$ to the north and is screened in the upper and middle sand layers.

There is no noticeable change in the negative slope of the head-versustime plot during the pumping at Well 9. This well is $116 \mathrm{ft}$ north of the piezometer and is screened in the middle sand layer.

It is unclear whether the pumping at Well 6 had any effect on the heads at this piezometer because there is no data immediately before the pumping began. This well is $156 \mathrm{ft}$ north of the piezometer and is screened in the middle sand layer.

It is also unclear whether this piezometer experienced the peak in heads around noon Wednesday. Although the heads seem to drop off between 
noon and midnight (except for one sudden increase), there is no corresponding rising of heads Tuesday into Wednesday morning.

There seems to have been no increase in head between Wednesday night and Friday morning. However, the general trend of the heads Friday is at a very steep slope (although the data is not clean). It is possible that the heads continued falling after the piezometers stopped taking data but before the general increase began.

It is impossible to tell if Well 3 had any effect on the heads at this piezometer because the data is not smooth enough to determine the slope. If anything, the slope is steeper during the pumping at Well 3 than later in the day. This well is $206 \mathrm{ft}$ north of the piezometer and is screened in the upper and middle sand layers.

For the same reason, it is hard to tell if the pumping at all the wells Friday afternoon caused any change in the head at this piezometer.

\section{Piezometer 10}

This piezometer is south of the fifth cable line in the upper section of the bluff. This piezometer, along with Piezometer 11, was placed in this area away from the pumping wells to act as a control section of the bluff. The ground surface elevation at this point is $624.4 \mathrm{ft}$, and the piezometer was set at a depth of $16 \mathrm{ft}$. This places the piezometer elevation at $608.4 \mathrm{ft}$ in the upper sand unit. The initial head reading at this piezometer was $588.8 \mathrm{ft}, 20 \mathrm{ft}$ below the piezometer. The initial pressure reading was $-58.7 \mathrm{kPa}$, outside the range listed on the instrument calibration sheets ( 0 to $70 \mathrm{kPa}$ ). Although these measurements are not within a believable range, it is hoped that the differentials are correct.

The initial readings at this point show almost no change in head with time. The slope of the head-versus-time plot is very close to zero.

During pumping at Well 8, the slope of the plot continues to be flat, showing no communication between this well and Piezometer 10. The well is $198 \mathrm{ft}$ north-northeast of the piezometer and is screened in the middle sand unit.

The head continues virtually unchanged during the pumping at Well 14. This well is $96 \mathrm{ft}$ away to the north and is screened in the upper and middle sand units. 
Similarly, the pumping at Well 9 has no effect on the heads at this piezometer. Well 9 is $202 \mathrm{ft}$ north of the piezometer and is screened in the middle sand unit.

Although it is difficult to determine the effect of Well 6 on any of the piezometers, the slope of the head-versus-time plot for this piezometer continues flat and unchanged during this pump test. The well is $242 \mathrm{ft}$ to the north and is screened in the middle sand layer. There is likely no communication between the two points.

There is no peak in heads in the middle of the day Wednesday, as at some of the other piezometers. The heads finished out the Wednesday data set with the same flat slope.

There is a small increase in heads between Wednesday night and Friday morning, but it is minor compared to other piezometers and the slope of the plot Friday is much flatter than at other locations.

There is no discernible effect on the heads at this piezometer during the pumping at Well 3, which is $300 \mathrm{ft}$ north and is screened in the upper and middle sand layers.

This piezometer also was not affected by the pumping of all the wells simultaneously Friday afternoon.

\section{Piezometer 11}

This piezometer is south of the fifth cable line in the lower section of the bluff. Like Piezometer 10, it was placed away from the pumping wells to measure conditions in the control section of the site. The ground surface elevation at this point is $601.2 \mathrm{ft}$, and the piezometer was set $16 \mathrm{ft}$ below ground. That puts the elevation of the piezometer at $585.2 \mathrm{ft}$ and in the upper sand unit. The initial head reading at this point was $586.0 \mathrm{ft}$, slightly above the piezometer elevation. The initial pressure reading was $2.4 \mathrm{kPa}$, within the range specified on the instrument calibration sheets ( 0 to $70 \mathrm{kPa}$ ). These head values are believable.

The head at this piezometer had a slightly increasing trend before the pump tests began. 
The pumping at Well 8 had no effect on this trend. This well is $206 \mathrm{ft}$ northeast of the piezometer and is screened in the middle sand layer.

Well 14 also failed to affect the heads at Piezometer 11 . This well is $100 \mathrm{ft}$ northeast and is screened in the upper and middle sand layers.

Similarly, Well 9 had no discernible effect on the heads at this piezometer. It is $203 \mathrm{ft}$ northeast and is screened in the middle sand layer.

It is difficult to determine the effect of Well 6 on any of the piezometers because of the lack of data immediately before the pump test. The data at Piezometer 11 is even worse because it is very noisy during the pumping at this well. Well 6 is $244 \mathrm{ft}$ northeast of this piezometer and is screened in the middle sand layer.

This piezometer did experience a very minor peak in heads about noon Wednesday. The magnitude of the increase and subsequent decrease in heads is very small compared to the other piezometers at the site.

There was a medium increase in heads noted at this location between Wednesday night and Friday morning.

Well 3 seems to have exerted no influence over the heads at this piezometer during its pumping test Friday. This well is $294 \mathrm{ft}$ northeast of Piezometer 11 and is screened in the upper and middle sand layers.

There also was no change in heads attributed to the pumping of all the wells simultaneously Friday afternoon.

\section{Piezometer 12}

This piezometer is north of the fourth cable line, in the upper section of the bluff. The ground surface elevation at this point is $650.0 \mathrm{ft}$, and the piezometer was set at a depth of $28.5 \mathrm{ft}$, putting its elevation at $621.5 \mathrm{ft}$. The piezometer is placed in the upper sand unit and is the only piezometer to be placed below the failure fault line. The initial head reading at this location was 641.84, about $20 \mathrm{ft}$ above the piezometer but below ground surface. The initial pressure value was $60.9 \mathrm{kPa}$, a value within the range listed on the instrument calibration sheets ( 0 to $70 \mathrm{kPa}$ ). This is more head than might be expected, but it is within the acceptable range for the instruments. Because it is underneath the fault line, it is possible that 
pressures here build up because if the difficulty of passing water through the smear from failure.

Initially, the slope of the head-versus-time plot is slightly positive, almost flat.

The pumping at Well 8 does not seem to affect this trend. Well 8 is $121 \mathrm{ft}$ northwest of this piezometer and is screened in the middle sand layer.

Well 14 also fails to exert any influence on the heads at this piezometer. This well is $65 \mathrm{ft}$ northeast and is screened in the upper and middle sand layers.

There also is no effect from pumping at Well 9, which is $133 \mathrm{ft}$ northwest of the piezometer. This well is screened in the middle sand layer.

As with the other piezometers, it is difficult to determine if Well 6 had any effect on the heads at this piezometer. It is $168 \mathrm{ft}$ to the northwest and is screened in the middle sand layer.

This piezometer did not experience the peak in heads around noon Wednesday, as some of the other piezometers.

There also was very little change between the heads Wednesday night and those Friday morning. It is designated a minor increase.

The pump test at Well 3 did not affect heads at this piezometer, either. This well is $215 \mathrm{ft}$ to the north and is screened in the upper and middle sand layers.

There seems to have been no effect on the head at this piezometer during the pumping of all the wells simultaneously Friday afternoon.

\section{Standpipe well tests}

\section{MP1}

The three standpipes are across the street, about $100 \mathrm{ft}$ from the edge of the bluff. MP1 is the middle-level standpipe, with screen depths from 65 to $86 \mathrm{ft}$. The ground surface elevation is about $672 \mathrm{ft}$ at this location, so the average screen elevation in this standpipe is $596.5 \mathrm{ft}$. The elevation of the 
water in this standpipe is usually about $592 \mathrm{ft}$. Two separate modified slug tests were run in this standpipe: one Wednesday and one Friday.

On Wednesday, 272 gal of water were pumped into the standpipe over a period of about $40 \mathrm{~min}$. This calculates to a flow rate of about $3.06 \mathrm{gal} / \mathrm{min}$. The head in that standpipe was measured continuously, using a probe in the hole. It took about $2.5 \mathrm{~min}$ for the head in the pipe to rise from $592 \mathrm{ft}$ to $604 \mathrm{ft}$. At this point, the head was such that the flow in from the hose equaled the flow out through the groundwater, and the head in the standpipe remained constant until the flow was stopped. It then slowly dropped to the original value of $592 \mathrm{ft}$.

On Friday, a similar test was run. This time, $47 \mathrm{gal}$ were pumped in $9 \mathrm{~min}$. This results in an average flow rate of $5.19 \mathrm{gal} / \mathrm{min}$. It took $2 \mathrm{~min}$ for the pipe head to rise to $604 \mathrm{ft}$. This head remained constant until the flow was shut off, and the head returned to its original level.

\section{MP2}

The three standpipes are across the street, about $100 \mathrm{ft}$ from the edge of the bluff. MP2 is the deep-level standpipe, with screen depths from 94.5 to $129.5 \mathrm{ft}$. The ground surface elevation is about $672 \mathrm{ft}$ at this location, so the average screen elevation in this standpipe is $560 \mathrm{ft}$. The elevation of the water in this standpipe is usually about $593 \mathrm{ft}$. Two separate modified slug tests were run in this standpipe: one Wednesday and one Friday.

On Wednesday, $134 \mathrm{gal}$ of water were pumped into the standpipe over a period of about $36 \mathrm{~min}$. This calculates to a flow rate of about $3.72 \mathrm{gal} / \mathrm{min}$. The head in that standpipe was measured continuously, using a probe in the hole. It took about $2.5 \mathrm{~min}$ for the head in the pipe to rise from $593 \mathrm{ft}$ to $607.6 \mathrm{ft}$. At this point, the head was such that the flow in from the hose equaled the flow out through the groundwater, and the head in the standpipe remained constant until the flow was stopped. It then slowly dropped to the original value of $593 \mathrm{ft}$.

On Friday, a similar test was run. This time, 44 gal were pumped in $12 \mathrm{~min}$. This results in an average flow rate of $3.92 \mathrm{gal} / \mathrm{min}$. It took $2 \mathrm{~min}$ for the pipe head to rise to $607.5 \mathrm{ft}$. This head remained constant until the flow was shut off, then the head returned to its original level. 


\section{MP3}

The three standpipes are across the street, about $100 \mathrm{ft}$ from the edge of the bluff. MP3 is the shallow-level standpipe, with screen depths from 13 to $19 \mathrm{ft}$. The ground surface elevation is about $672 \mathrm{ft}$ at this location, so the average screen elevation in this standpipe is $656 \mathrm{ft}$. After a very rainy month, the elevation of the water in this standpipe was about $671.2 \mathrm{ft}$, within $1 \mathrm{ft}$ of ground surface. A single pump test was run in this standpipe Wednesday.

Approximately 0.15 gal of water was pumped into the standpipe in about $20 \mathrm{sec}$. The speed of the test made accurate measurements impossible, so the volume was calculated knowing the diameter of the standpipe and the change in head, which occurred over those $20 \mathrm{sec}$. The head in that standpipe was measured continuously, using a probe in the hole. The head in the pipe rose from $671.2 \mathrm{ft}$ to $672.5 \mathrm{ft}$, almost instantaneously. The hose was removed from the standpipe after only $20 \mathrm{sec}$, then the head gradually dropped to the original value of $671.2 \mathrm{ft}$.

\section{Well effects analysis}

The wells were set up to pump until the water level is within $1 \mathrm{ft}$ of the pump. At this point, the well stops pumping and remains off until the head has risen to $3.5 \mathrm{ft}$ above the pump. Then, the cycle continues.

Because the diameters of the well pipes were 3 in., the cross-sectional area is just more than $7 \mathrm{sq}$ in. The length between the point where the well turns on and the point where it turns off is $2.5 \mathrm{ft}$, making the volume of water between those two points about 0.92 gal. Most of the on-cycles removed only slightly more water, meaning the pumps were pumping too hard for the soil, so they simply were emptying the pipe of the water, then turning off while the head slowly rose again.

\section{Well 8}

Well 8 was the first test to be run Tuesday afternoon. It was the only middle tier well to have any water in it. The test was run for about $80 \mathrm{~min}$ and, during that time, $18.86 \mathrm{gal}$ of water were pumped from the well. After the first few cycles, the on-cycles at this well lasted an average of $12 \mathrm{sec}$, while the off-cycles were about 3:45 in length. J ust less than 1 gal of water was removed during each on-cycle. 
Piezometers 2 and 7 showed a medium response to the pumping in this well. In addition, Piezometer 8 Deep had a minor response to the pumping. All three of these piezometers are fairly nearby and are in the same geologic unit as the screen on Well 8.

Additionally, Piezometers 3 and 4 are in the same geologic unit as this well. They also are fairly near the well, definitely nearer than Piezometer 7 or 8 Deep. Despite this, they show no response during the pump test. It is possible there is a geologic disturbance that prevents hydraulic communication. This disturbance is not shown in the current geology for the ADH model and might affect the calibration.

None of the other piezometers were affected by the pumping at Well 8.

\section{Well 14}

The next well to be tested was Well 14. This is a lower tier well that is fairly distant from Well 8. The pump test lasted just fewer than $70 \mathrm{~min}$, and the total amount of water pumped from the well was $14.83 \mathrm{gal}$. After the first few cycles, the average on time for the pump was only about $2 \mathrm{sec}$. Although the off-cycles lasted an average of 1:38, the deviation of the times for each cycle varied greatly from about $50 \mathrm{sec}$ to more than $5 \mathrm{~min}$. Each on-cycle removed about $0.35 \mathrm{gal}$. The reason for this low yield is unknown. More than that amount of water should have been sitting in the pipe each time. Possibly, there was an error in construction or the flow meter was faulty.

The only piezometer that was affected by pumping at Well 14 was Piezometer 9 Shallow, which is very nearby and located in the same geologic unit.

Piezometer 9 Deep also is nearby and located in the same unit, but the data for this piezometer is very noisy and difficult to analyze. The effects here are unknown.

All the other piezometers were unaffected by pumping at this well because of their distance from the pumping well.

\section{Well 9}

Well 9 is located in the lower tier of the bluff near Well 8. The pumping at this well lasted slightly more than an hour and removed 18.3 gal of 
groundwater. Discounting the first few cycles, the well was on for an average of $12 \mathrm{sec}$ for each cycle. It took an average of $3.5 \mathrm{~min}$ to recover from each pumping cycle. Each cycle removed 0.99 gal.

This well had a fairly large area of influence. Piezometers 7 and 8 Deep had a major response to the pumping. Piezometers 2, 3, and 8 Shallow had minor responses.

It was expected that Piezometers 3 and 4 would have the largest responses since they are very close to the well and in the same unit. Piezometer 8 Deep also is fairly close and set in the same geologic layer. Piezometer 7 , however, is not especially close and is set in a different layer. It is unclear why Piezometers 7 and 8 experienced a greater effect than Piezometers 2 and 3. It is difficult to decide if Piezometer 4 was affected by the pumping.

\section{Well 6}

Because there is no data immediately before the start of pumping at Well 6, it is difficult to determine which locations were affected by this test. No piezometers are very close to this well. Piezometers 2, 3, 4, and 6 would be the most likely to be affected.

\section{Well 3}

Although there is a little more data before the pumping at Well 3, it is still hard to determine an affect. Most of the piezometers already were experiencing a sharp increase in head at this time. The only piezometer nearby was No. 5, but it is located in a different geologic layer and the effect is minor if existent.

\section{All wells}

On Friday afternoon, all the wells were turned on to see which areas of the bluff could be dewatered by the entire system. The major effects were seen at Piezometers 9 Shallow and 8 Deep. Medium effects were observed at 8 Shallow and 3. Finally, minor changes occurred in Piezometers 2 and 7. The wells with the greatest influence in the individual tests were 8,9 , and 14 , and it is the piezometers in these areas that experienced the greatest effects when all the wells were turned on together. 


\section{Wednesday peak}

Many of the piezometers began Tuesday morning with an increasing head trend. These trends continued until about noon Wednesday when they all simultaneously began decreasing at a similar rate. The decrease continued until the piezometers stopped recording around midnight. A slug of rainfall passing through probably caused this peak.

Major peaks were seen at Piezometers 7 and 8 Shallow; medium peaks were seen at Piezometers 2, 3, and 8 Deep; and minor peaks were observed at Piezometers 11 and 4. With the exception of Piezometer 11, these points are within the major slump zone where large effects were seen from the pump tests; so the piezometers must be set in conductive materials that are affected easily by environmental changes.

When the outer piezometers $(5,6,1,12$, and 10$)$ are removed from the list, there is a loose correlation between the height of the piezometer above the modeled fault failure line and the magnitude of the Wednesday peak. Those that are higher experienced a larger peak.

It also is not clear which rainfall event resulted in the peak. According to precipitation data from the weather station at this site, there was a storm event early Tuesday morning that yielded $0.22 \mathrm{in}$. This might not be enough rain to cause the large peak seen in some of the piezometers. There was a minor amount of rain Sunday night (0.1 in.) and a much larger storm around midnight Saturday (0.5 in.). After the model is calibrated, it might be possible to determine which rainfall event caused the peak.

\section{Friday increase}

Most of the piezometers also increased in head significantly between Wednesday night and Friday morning. Slopes on the head-vs.-time plots were fairly steep Friday. Major effects were noted in Piezometers 8 Shallow and 9 Shallow, and medium effects were seen in Piezometers 3, 4, 5, and 7. Minor effects were observed in Piezometers 6, 2, 1, 8 Deep, 12, and 10. Piezometer 9 Deep has noisy data that is difficult to evaluate. Piezometer 5, though listed with a medium effect, has odd data, too.

These increases are believed to have been caused by the slug tests in the standpipe wells accomplished Wednesday afternoon. When a comparison of the geologic strata and location of each piezometer were combined, it was 
found that those piezometers with the greatest effect were in or near the middle sand layer (where MP1 is screened) and were closest to a line perpendicular to the bluff face and passing through MP1. Since flow is assumed to be generally perpendicular to the bluff face, it makes sense that those piezometers close to the direct path of flow from the standpipe would experience a greater effect. The effect might be damped for piezometers that are outside the direct path. 


\section{Appendix E: Bibliography of Allegan County Bluff Stabilization Technology Transfer Documents}

Brotz, A. L. 2008 (in preparation). Geotechnical characterization of coastal Lake Michigan sands at bluff failure sites, Allegan County, Michigan. MS thesis, Western Michigan Univ.

Chase, R. B., and A. E. Kehew. 2000. Potential stabilization of Great Lakes shoreline bluffs by removal of ground water. Geological Society of America Abstracts with Programs 32(7):A-516.

Chase, R. B., and A. E. Kehew. 2003. Ground water and slope stability contributions. In Living on the coast: Protecting investments in shore property on the Great Lakes, ed. J . P. Keillor, University of Wisconsin, Sea Grant Advisory Services.

Chase, R. B., and A. E. Kehew. 2004. The contribution of ground water to the destabilization of coastal bluffs in a Great Lakes environment. In Association of Engineering Geologists, Vol. 47 Abstracts Volume, 41.

Chase, R. B., and A. E. Kehew. 2004. The monitoring and modeling of earth slides in heterogeneous glacial materials: Examples from the U.S. Great Lakes coast. In 32 ${ }^{\text {nd }}$ International Geological Congress Abstracts, 209.

Chase, R. B., and A. E. Kehew. 2005. Stabilizing Great Lakes coastal bluffs by controlled removal of ground water. In Abstract Volume, International Association of Great Lakes Research.

Chase, R. B., Kehew, A. E., and Montgomery, W. W. 2001. Significance of ground water in triggering cohesive bluff failures, Lake Michigan case study. In Proceedings of the Coastal Zone 01 Conference, NOAA, Cleveland, $\mathrm{OH}$.

Chase, R. B., A. E. Kehew, and W. W. Montgomery. 2001. Determination of slope displacements and causes using geometric models and climate data. In Landscape erosion and evolution modeling, eds. R. S. Harmon and W. W. Doe III, 57- 87, New York: Kluwer Academic Publishers.

Chase, R. B , A. E. Kehew, and W. W. Montgomery. 2001. Determining the kinematics of slope movements using low-cost monitoring and cross-section balancing. Environmental and Engineering Geoscience VII(2):193-203.

Chase, R. B., A. E. Kehew, M. E. Glynn, J . P. Selegean, and R. L. Erickson, R. L. 2005. Mitigation of slope failures in Great Lakes coastal environments by removal of ground water. Geological Society of America Abstracts with Programs 37.

Chase, R. B., A. E. Kehew, M. E. Glynn, and J . P. Selegean. 2007. Modeling debris slide geometry with balanced cross-sections: a rigorous field test. Environmental and Engineering Geoscience XIII(1):193-203. 
Ferrick, M. G., L. W. Gatto, and C. R. Williams. 2004. Cold regions data acquisition and analysis for Section 227 National Shoreline Erosion Control Development and Demonstration Program Miami Park South, Allegan County Michigan: ERDC/CRREL TN-05-6. Hanover, NH: U.S. Army Engineer Research and Development Center Cold Regions Research and Engineering Laboratory.

Hansen, P. H., S. E. Howington, and M. E. Glynn. 2007. Flow model mtudy for Section 227 Demonstration Project in Allegan County, Michigan. ERDC TR-07-12. Vicksburg, MS: U.S. Army Engineer Research and Development Center.

Kaunda, R. B., R. B. Chase, A. Kehew, and K. Kaugars. 2006. Neural network modeling of failure surface development in bluff displacement studies using a simple poleand-cable survey system. Geological Society of America Abstracts with Programs 38(4).

Kaunda, R. B., R. B. Chase, and A. Kehew. 2006. Effects of ground water flow patterns on slope stability. Geological Society of America Abstracts with Programs 38(7).

Kaunda, R. B., R. B. Chase, and A. Kehew A. 2006. Using rate-dependent relationships from inclinometer data to monitor landslides and slope movements. Geological Society of America Abstracts with Programs 38(7).

Kaunda, R. B., R. B. Chase, A. E. Kehew, and K. Kaugars. 2005. Application of a Gaussian quadrature algorithm to cross-section constructions in bluff displacement modeling studies. Geological Society of America Abstracts with Programs 37:518.

Kaunda, R. B., R. B. Chase, A. E. Kehew, K. Kaugars, and J . P. Selegean. 2008. Interpretation of a progressive slope movement using balanced cross sections and numerical integration. Environmental and Engineering Geoscience 14(2):121-131.

Kaunda, R. B. 2007. Some applications of Gaussian quadrature and neural network modeling in earth flows and other slow-moving landslides in cohesive slope materials. PhD diss., Western Michigan Univ.

Kehew, A. E., R. B. Chase, M. E. Glynn, J . P. Selegean, and R. L. Erickson. 2005. Design of monitoring and dewatering instrumentation for stabilization of receding Lake Michigan bluffs. Geological Society of America Abstracts with Programs 37.

Selegean, J . P. 2004. Coastal bluff stabilization through active and passive dewatering Section 227 Demonstration Project, Allegan County Michigan. Presentation, ASBPA Conference 2004, New Orleans, LA.

STS Consultants, LTD. M. Emrick and J . Matus. 2003. Geotechnical investigation, bluff stabilization demonstration project - Allegan County, Michigan. STS Consultants, LTD., Lansing, MI. STS Project No. 74067, March 11, 2003.

STS Consultants, LTD. M. Emrick and J . Matus. 2005. Geotechnical investigation bluff stabilization demonstration project, Allegan County Michigan. Prepared for U.S. Army Corps- Detroit District, Delivery Order No. 0011, Contract No. DACW 3502-D-002 STS Project No. 7-74257A.

Young, G. C. 2004. Slope stability analysis of a Lake Michigan coastal bluff. MS thesis, Western Michigan Univ. 


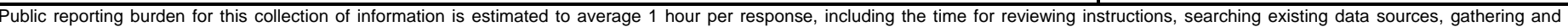

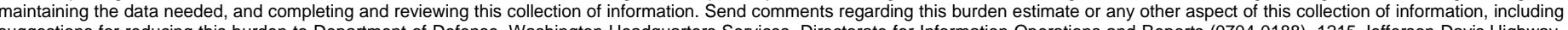

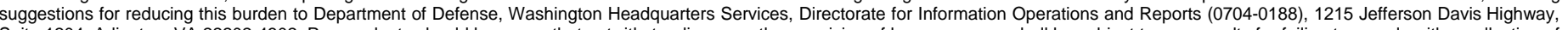

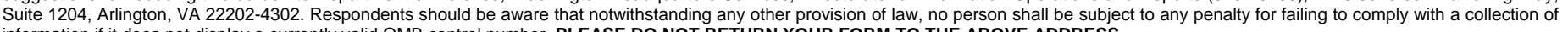
information if it does not display a currently valid OMB control number. PLEASE DO NOT RETURN YOUR FORM TO THE ABOVE ADDRESS.

\begin{tabular}{|l|l|l|}
\hline 1. REPORT DATE (DD-MM- $Y Y Y Y)$ & 2. REPORT TYPE & 3. DATES COVERED (FrOm - To)
\end{tabular}

\begin{tabular}{|l|l} 
September 2012 & Final
\end{tabular}

4. TITLE AND SUBTITLE

2001-2008

Lake Michigan Bluff Dewatering and Stabilization Study — Allegan County, Michigan

5a. CONTRACT NUMBER

5b. GRANT NUMBER

6. AUTHOR(S)

M. Eileen Glynn, Ronald B. Chase, Alan E. Kehew, Michael G. Ferrick,

Clarissa M. Hansen, and James P. Selegean

5c. PROGRAM ELEMENT NUMBER

5d. PROJECT NUMBER

5e. TASK NUMBER

5f. WORK UNIT NUMBER

7. PERFORMING ORGANIZATION NAME(S) AND ADDRESS(ES)

U.S. Army Engineer Research and Development Center, Geotechnical and Structures

Laboratory, 3909 Halls Ferry Road, Vicksburg, MS 39180-6199, and Cold Regions

Research and Engineering Laboratory, Hanover, NH 03755-1290; Western Michigan

University, Department of Geosciences, Kalamazoo, MI 49008; USACE Detroit District,

477 Michigan Avenue, 6th Floor, Detroit, MI 48226-1027; Malcolm Pirnie, Inc.,

640 Freedom Business Center, King of Prussia, PA 19406

9. SPONSORING/MONITORING AGENCY NAME(S) AND ADDRESS(ES)

Water Resource and Development Act 1996

National Shoreline Erosion Control Development and Demonstration Program

U.S. Army Corps of Engineers, Washington, DC 20314-1000

Western Michigan University, Kalamazoo, MI

12. DISTRIBUTION/AVAILABILITY STATEMENT

Approved for public release; distribution is unlimited.

13. SUPPLEMENTARY NOTES

Funding was provided by the National Shoreline Erosion Control Development and Demonstration Program (Section 227) under

the Water Resources and Development Act, the Flood and Coastal Storm Damage Reduction Research Program (FCSDR) at

ERDC, the Regional Sediment Management (RSM) research under the System-Wide Water Resources Program at ERDC, and In-

Kind Funding and Activities of Western Michigan University, Kalamazoo, MI.

14. ABSTRACT

In the Great Lakes region, bluff recession is a major cause of residential, commercial, municipal, and federal property loss. The average rate of recession in Allegan County, Michigan, ranged from 1 to $2 \mathrm{ft}$ per year, from 1831 to 1958, or a total of $130 \mathrm{fo} 258 \mathrm{ft}$ over 127 years (Powers 1958). From 1938 to 1996, a 0.1 to $1.7 \mathrm{ft}$ per year recession rate was measured, for a total land loss of 5 to 100 ft over 58 years (Montgomery 1998). Reports show that recession rates are not uniform along the shoreline, nor are they similar during two different time periods at a given site (Chamberlin 1877; Powers 1958; Seibel 1972; Montgomery 1998; Chase et al. 2000). It is difficult to predict future rates of recession. Also, it is evident that recession has not slowed with the introduction of modern stabilization structures.

The purpose of this research is to investigate the natural factors that influence lake-bluff instability and to demonstrate an innovative approach (i.e., dewatering the bluff) for deterring or slowing the recession rate. Three geologically distinct sites along the Lake Michigan coast in Allegan County were chosen. In 2004, measurement instrumentation was installed at each of the sites. Part of each site was dewatered using submersible pumps or gravity drains, while another part of each site was not. A total of 76 in-place inclinometers (IPIs) and 28 vibrating wire piezometers (VWPs) among 26 monitoring wells, 45 dewatering wells, and two weather stations were installed.

(continued)

\section{SUBJECT TERMS}

Active and passive dewatering

Balanced Cross Section Method

Bluff lithology

Bluff recession

Demonstration project

16. SECURITY CLASSIFICATION OF:

a. REPORT

UNCLASSIFIED b. ABSTRACT

UNCLASSIFIED
Groundwater freeze/thaw

Groundwater Modeling System (GMS)

Lake Michigan

Lakeshore bluff slumping
Numerical modeling

Slope stability

Water Resources and Development Act

Wave action erosion

UNCLASSIFIED

17. LIMITATION
OF ABSTRACT

18. NUMBER
OF PAGES

182 19a. NAME OF RESPONSIBLE PERSON

19b. TELEPHONE NUMBER (include area code) 


\section{ABSTRACT (concluded)}

The original work plan called for five seasonal cycles of dewatering tests. The sites were monitored from November 2004 to May 2007, and hourly data were collected. Data has not been analyzed in full due to a lack of funding since 2007. Therefore, no significant conclusions could be produced. At the time of this report, no conclusion can be made concerning the success of bluff dewatering as a mitigation strategy. Future reports are in the works. 